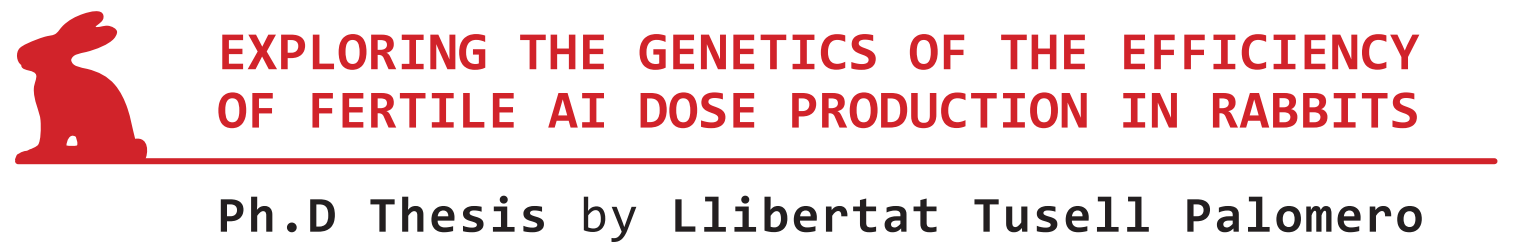

Under supervision of: Directors:

Dr. Miriam Piles Rovira and Dr. Manel López Béjar Department advisor: Prof. Manuel Baselga Izquierdo

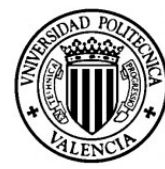





\section{EXPLORING THE GENETICS OF THE EFFICIENCY OF FERTILE AI DOSE PRODUCTION IN RABBITS}

A thesis submitted to the Polytechnic University of Valencia in partial fulfilment of the requirements for the degree of doctor of philosophy

By

\section{LLibertat Tusell Palomero}

Sig.

Thesis Directors

Dr. Miriam Piles Rovira Dr. Manel López Béjar

Sig. Sig.

Department advisor

Prof. Manuel Baselga Izquierdo

Sig. 
L'amor d'un pare vers una filla és incondicional i proporcional al d'una filla pel seu pare. A en Jordi, el meu pare. 
Miriam, vas trucar-me aquell dia per que creies en mi. M'agraden la teva il·lusió, les teves paraules directes, el teu rigor i l'alt nivell d'exigència en tot el que fas. Has dirigit aquesta tesi prioritzant la meva formació. Gràcies per entregar-te en aquesta tesi tant com jo mateixa. M'has acompanyat de la mà en aquest bonic viatge: com a directora de tesi i com amiga.

Gràcies a tots els conills que han participat en aquest projecte: els mascles i femelles de la línia Caldes i les femelles creuades PxV. Especialment el mascle 190050 sempre entusiasta i disposat a col-laborar. 130473, 150423 i 190092 molt complidors i els outliers 170072, 171302 i 140224. Gràcies a les femelles creuades de la granja de Berga 899640, 812662, 812600 i molt especialment a Caterina, Bruna, Paula, Modesta, Anna, Filipa, Magalí, Paca, Juani $i_{i}(i=1, \ldots, 6)$, Nita i Luci. En nom de tots, us demano disculpes per no poder-vos llegir bé el tatuatge i haver-vos de fer un bateig civil a peu de granja amb aquests noms tan 'originals', sobretot a tu: Leovigilda, espero que no ens ho tinguis en compte. Als animals de granja. Pel vostre infinit altruisme i la vostra generositat impagable. Gràcies per donar la vida i la llibertat per nosaltres.

Vull agrair molt especialment les seves contribucions a aquesta tesi i a la meva formació a les següents persones: Dr. Andrés Legarra (eskerrik asko!), Dr. Ignacio Aguilar (muchas gracias, ¿ta?), Dr. Juan Pablo Sánchez (muchas gracias skyperas ;-)), Prof. Romdhane Rekaya (نكراً), Dr. Loys Bodin (merci beaucup!) and Prof. Manuel Balsega (¡muchas gracias!). Als professors del màster de millora genètica biotecnologia de la reproducció.

Agrair als companys de la Unitat de Cunicultura de l'IRTA els bons moments compartits i la seva inestimable participació en el treball experimental i en l'obtenció de les dades amb les que hem realitzat els treballs que composen aquesta tesi. Gràcies Mònica, Òscar, Carme, Anna, Juan, Àlex, Bernat, Mohammed, Josep i Oriol. També les meves Núries, Aloy i Picornell, que em van acompanyar en els meus inicis conillaires, ja fa uns quants anys. A tots els dec bons moments, aprenentatge i en part també, haver pogut realitzar aquesta tesi. Gràcies a tota la gent de la Torre Marimon.

Gràcies a la gent del departament de Sanitat i Anatomia Animals de la Universitat Autònoma de Barcelona. Al Manel i al Carlos, i molt especialment a les meves teresines: Irina, Cristina i Sònia. Per tots els riures i les alegries compartides i pels divendres esgotadors amb els nostres particulars festivals del semen. Gràcies per ajudar-me en el treball experimental i pels bons moments viscuts. Gràcies a tu també Mireia.

Gracias/ Eskerrik asko/ merci beaucup! al grupo interespecífico del modelo producto vs modelo aditivo: Dra. María Jesús Carabaño, Dra. Clara Díaz, Dr. Oscar González Recio, Dra. Evangelina López de Maturana, Dra. Eva Ugarte, Dra. Ingrid David et Dr. Loys Bodin. 
Jules thanks a lot for the English review of this thesis and your suggestions. Thanks Rod for your help in preparing the viva of my thesis and thanks Jamie for your English manuscript corrections.

Mi agradecimiento al Instituto Nacional de Investigación y Tecnologia Agraria y Alimentaria (INIA) por financiar mi beca predoctoral y el proyecto INIA RTA2005-00088CO2 del que ha formado parte ésta tesis.

Mil gràcies Eva, pel disseny de la tesi.

A la meva amiga i companya de màster i pis a València, Marina. Als meus bons companys i amics de màster, especiament: Mehdi, Mohammed Ragab, Sofiane, Javier, Coşkun y Jorge Daniel. A les meves reboniques/remaques valencianetes Lola i Raquel. A la Mireia Bonfill, per trucar al xino i ajudar-me fins molt tard a maquetar la tesina i per tantes altres coses.

Thanks to the people of the Animal and Diary Science Department, University of Georgia (Athens, GA). My special thanks to Romdhane, the flowers Ching-Yi Chen (Vicky), Huiyu Wang (Joy), Jamie and Chyong-Huoy Huang, and our lovely gardener Dennis. Also thanks to Tsogo, Raphael, Juan, Mike, Ignacy Ramata, Regina and Ryan. My roommates Tamar, Lindsey and Picasso the cat. I'm missing my best friends there: Hiram and Cintia.

Je tiens à remercier toutes les personnes du département INRA-SAGA (Castanet-Tolosan, France) pour leur accueil chaleureux qui a fait que je me suis sentie bien les deux fois où je suis venue à Toulouse. Merci spécialement à mes amis: Cécile, Julien, Momo et David, Simon, Benjamin, Cyril, Hughes, Aurélie, Chloé, Mila et Carine. Merci à mon compatriote Edmond et aux informaticiens. Je remercie également Ingrid, Loys, Michèle Theau, Jean Michel Brun, Zulma et Andrés. Mon prof de français Willy et son épouse Mary, mes parents adoptifs de Toulouse. Et finalement mes excellents colocataires de mon deuxième séjour: la Fille Karine, Guillaume, Boris, Julien et le gros animal qui a la peau fine.

A la meva mare i al meu germà, sempre.

A tu Ferran. Dos arbres una mica separats fan més ombra que dos que estan molt junts: per l'amor d'ombra fresqueta i emocionant que compartim.

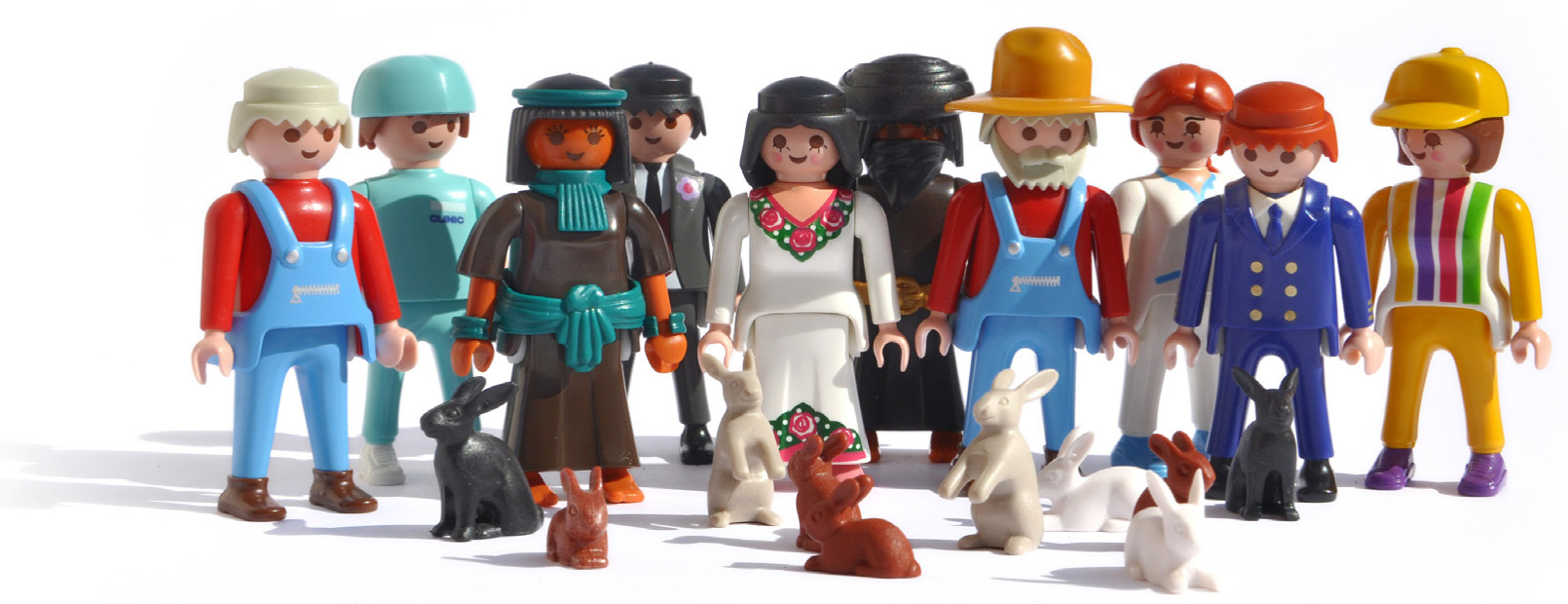


Get out your measuring cups and we'll play a new game come to the front of the class and we'll measure your brain we'll give you a complex, and we'll give it a name.

Andrew bird, Measuring cups.

Vaig somiar que tenia un desig: Semblava que veia les condicions de la meva vida, en un escenari lluminós: com podia canviar, com podia no fer-ho: l'origen de la necessitat i de l'elecció.

Frank Bidart, Golden State 


\section{Abstract}

The general aim of this thesis has been to analyse sources of variation for some of the most important components of fertile artificial insemination (AI) dose production in order to explore the interest and limitations of different strategies for their genetic improvement in a paternal line of rabbits selected for growth rate. These components refer to seminal production and quality traits, being considered the male reproductive performance as the final expression of the effect of the seminal characteristics and the effect of the interaction among them and with the female.

Threshold and linear mixed models have been used in all the studies included in this thesis under a Bayesian approach.

In chapter 1, genetic parameters of male libido and characteristics involved in the ejaculate rejection criteria and semen production traits have been estimated as well as the genetic relationship between all of these traits with average daily gain (ADG). A linear tri-trait model was used to analyse sperm concentration, ejaculate volume and ADG. Threshold and linear two-trait models were used for the analyses of the remaining traits with ADG. The amount of ejaculates rejected for AI was high (38\%), primarily due to low individual sperm motility scores. Male libido and variables related to the quality of the ejaculate such as presence of urine and calcium carbonates in the ejaculate, individual sperm motility, semen $\mathrm{pH}$ and suitability for $\mathrm{AI}$ of the ejaculate (which involves the subjective combination of several semen quality traits) were found to be lowly heritable, but repeatable. This indicates performance of bucks for seminal quality traits and libido in AI centres would be more strongly affected by management practices rather than genetic selection. Semen production traits (sperm concentration, ejaculate volume and total number of sperm) exhibited moderate values of heritability $\left(\mathbf{h}^{2}\right)$ suggesting the possibility of effective selection for these traits. A moderate to high negative genetic correlation $\left(\mathbf{r}_{\mathbf{g}}\right)$ was estimated between sperm concentration and ejaculate volume suggesting that total number of sperm would be of most interest to select for. The ADG was estimated to have a moderate to low $h^{2}$, to have a low, positive $r_{g}$ with sperm concentration, to have a low, negative $r_{g}$ with ejaculate volume, and to be genetically uncorrelated with all remaining traits analysed. Therefore, it is concluded that selection for increasing ADG in paternal lines is expected to have no detrimental effects on male libido and traits involved in semen quality and little to no effect on semen production traits.

The aim of chapter 2 was to explore the feasibility of indirect selection of male contribution to fertility through the use of semen $\mathrm{pH}$ because it is an immediate, not expensive and easy to measure global marker of the expression of some seminal quality traits. Different methods 
were used to model the relationship between $\mathrm{pH}$ of the pool of ejaculates of each male in the day and male fertility (defined as the failure or the success to AI): 1) ignoring genetic and environmental correlations and including $\mathrm{pH}$ either as a covariate or as a cross-classified effect on fertility, 2) a two-trait mixed model, and 3) recursive two-trait mixed models. Crossbreed does from 2 maternal lines were artificially inseminated with buck semen from a paternal line in a commercial farm environment. A negative, and almost linear, effect of $\mathrm{pH}$ on fertility was detected. The semen $\mathrm{pH}$ and male fertility $\mathrm{h}^{2}$ were approximately 0.18 and approximately 0.10 across all the models, respectively. Genetic correlations between traits were negative, but the highest posterior density interval at 95\% included zero in all the model were it was estimated. All models predicted fertility data reasonably well and the correlation between EBV (estimated breeding values) in all models was close to 1. Thus, no differences in results were obtained considering, or not considering, genetic and environmental correlations between $\mathrm{pH}$ and male fertility and assuming, or not assuming, recursiveness between each trait. This is because the magnitude of the effect of $\mathrm{pH}$ on fertility was not large enough and the low precission obtained for the parameter estimates. Therefore, the same results were obtained even though the models were of different complexity. From this chapter, it can be concluded that semen $\mathrm{pH}$ could be an interesting trait to be used to select qualitatively better ejaculates for AI to increase fertility. However, it does not seem to be advisable to use semen $\mathrm{pH}$ as a selection criterion to improve male fertility by indirect selection.

In Chapter 3, male and female contributions to fertility were jointly analysed using two different models: the additive threshold model and the product threshold model, both adequate for the analysis of binary AI results. The additive threshold model proposes that the underlying variable of fertility is the result of the sum of genetic and environmental effects of the two individuals involved in the mating whereas the product threshold model assumes that an observed AI outcome is the result of the product of two unobserved variables corresponding to the fertility of the two individuals involved in the mating. Both, the product and additive threshold models showed similar ability to predict an independent set of fertility data. For example, the percentage of wrong predictions was 38\% in both models and they also did not differ in the mean square error of the prediction, the sensitivity and specificity of the prediction and in the positive and negative predicted values obtained. The product threshold model allows calculating the probabilities of fertility success for each sex as well as evaluating which sex is responsible for an AI failure. Male and female probabilities of a fertility success were similar and high (87\% and $83 \%$, respectively) and the percentages of AI failure specifically due to male and female fertility problems were $39 \%$ and $54 \%$, respectively. Although estimates of the genetic correlation between male and female contributions to fertility were imprecise, both models showed similar values: 0.21 and 0.31 for the product and the additive model, respectively. However, interpretation of some of the parameter estimates 
obtained with the product threshold model (e.g. $\mathrm{h}^{2}$ and variance components) is not straightforward and cannot be compared with the corresponding figures obtained with the additive threshold model. The $\mathrm{h}^{2}$ for the male contribution to fertility was 0.17 and 0.04 in the product and additive threshold model, respectively. The correlation between the EBV for male and female contributions to fertility obtained in each model were close to 1 and the percentage of animals in common in the top $10 \%$ best/worst animals was high (more than $76 \%$ ) in both models. Hence, from the point of view of selection in rabbits, irrespective of the model of choice, small changes in the evaluation of the individuals for fertility would be encountered.

Previous studies concerning reproductive performance after natural mating in rabbits and in other livestock species reported an almost null male contribution. Chapter 4, aimed to explore if individual variation in the male contribution to fertility and prolificacy could be better observed under limited conditions of AI, such as decreased sperm concentration, small or null preselection of ejaculates for any semen quality trait, or a long storage period of the AI doses. Therefore, it was determined if an interaction existed between male genotype and the AI conditions for male effects on fertility and prolificacy after AI performed under different conditions. Fertility (success or failure to AI) and prolificacy (total number of kits born per litter) were analyzed in 2 sets of independent analyses and the existence of interaction was assessed in each set using the Character State model in which the phenotype measurements in the different environments were analysed as different traits. In the first step, the different AI conditions were determined uniquely by the sperm dosage $\left(\begin{array}{llll}10 & \text { and } & 40 \times 10^{6}\end{array}\right.$ spermatozoa/mL). In the second step, the different conditions were determined by all the factors involved in the AI process as a whole (conditions and duration of the storage period of the dose, female genotype, and environmental conditions on the farm). Threshold and linear two-trait models were assumed for fertility and prolificacy, respectively. The sperm dosage had a clear effect on fertility and prolificacy, which favoured the greater dosage $(+0.13 \%$ and +1.25 kits born, respectively). Prolificacy was more sensitive to sperm reduction than was fertility. Male $\mathrm{h}^{2}$ for fertility were 0.09 for both sperm dosages, and were 0.08 and 0.06 for male prolificacy with a smaller and larger sperm dosage, respectively. No genotype $\times$ sperm dosage interaction was found. Therefore, the same response to selection to improve male reproductive performance could be achieved at any sperm concentration. On the other hand, an interaction could exist between the male genotype and AI conditions for male effect on fertility and prolificacy, such as the time and storage conditions of the AI doses, the female genotype, or the environment. There could be a scale effect because of differences in the magnitude of the additive variances for male fertility and prolificacy after AI in the two AI conditions. Moreover, rankings of male EBV for those traits could differ depending on AI conditions because genetic correlations of fertility and prolificacy after AI at different 
conditions could be said to be different from 1 (the probability of a genetic correlation of being less than 0.75 was $83 \%$ for male fertility and $100 \%$ for male prolificacy). The existence of this interaction also implies that conditions that give the maximum genetic progress could be chosen to optimize the breeding program for male reproductive performance under given conditions of semen utilization.

Last chapter of this thesis has aimed to determine the critical periods around the AI time in which the environmental temperature has a major effect on male and female contributions to fertility. To achieve that, we have used the product threshold model as it allows providing specific estimates of the effects affecting each one of the members involved in an AI outcome. Data of AI and records of indoor daily temperature were used. The average maximum daily temperature and the proportion of days of the period in which the maximum temperature was above $25^{\circ} \mathrm{C}$ were used as temperature descriptors. These descriptors were calculated for several periods around the AI day. In the case of the males, four periods of time covered different stages of the spermatogenesis, the transit through the epididymus of the sperm and the AI day and fertilization. For the females, five periods of time covered the phases of preovulatory follicular maturation, the AI day and ovulation, fertilization and peri-implantational stage of the embryos, the embryonic and early fetal periods of gestation and finally the late gestation until birth. The effect of the different temperature descriptors was estimated in the corresponding male and female liabilities in a set of threshold product models. The environmental temperature of the AI day seems to be the most relevant temperature descriptor affecting male fertility, since high temperature records in the AI day caused a decrease in male fertility (representing a loss of $6 \%$ in male fertility with respect to thermoneutrality). Departures from the thermo-neutral zone in temperature descriptors covering several periods before AI until early gestation had a negative effect on female fertility, being especially sensitive the peri-implantational period of the embryos (representing a loss of 5-6 $\%$ in male fertility with respect to thermo-neutrality). The latest period of gestation was unaffected by the temperature. We can conclude that the product threshold model allowed us to estimate that male and female fertility are specifically affected by temperature in different periods around the insemination time. However, the magnitude and the persistency of the temperatures reached in the commercial conditions of this study do not seem to be high enough to lead to a large effect on male and female rabbit fertility 


\section{Resum}

L'objectiu principal d'aquesta tesi ha estat analitzar les fonts de variació d'alguns dels components que intervenen en la producció de dosis fèrtils per al seu ús en inseminació artificial (IA). L'anàlisi d'aquests components té com a finalitat explorar el possible interès i les limitacions de l'ús de diferents estratègies de selecció per la seva millora genètica en una línia paternal de conills seleccionada per velocitat de creixement. Aquests components inclouen tant caràcters de producció i qualitat seminal com el comportament reproductiu del mascle. Aquest darrer component, està considerat com l'expressió final conjunta dels caràcters de qualitat seminal i l'efecte de la interacció entre ells i amb la femella.

En tots els estudis realitzats s'han emprat models mixtes llindar i lineals sota una aproximació Bayesiana.

En el capítol 1, es varen estimar els paràmetres genètics de la libido del mascle i de les característiques seminal involucrades en el criteri que s'utilitza per la determinació de la idoneïtat dels ejaculats per ser utilitzats en inseminació. També es va determinar la relació genètica de tots aquests caràcters amb la velocitat de creixement (ADG, average daily gain). La concentració espermàtica, el volum de l'ejaculat i l'ADG es varen analitzar conjuntament en un model lineal tricaràcter. Cadascun dels altres caràcters es va analitzar amb l'ADG utilitzant models llindar o lineals bicaràcters.

La quantitat d'ejaculats que varen ser descartats per a inseminació va ser elevada (38\% respecte del total d'ejaculats recollits). La raó principal d'eliminació va ser la baixa motilitat espermàtica individual. La libido del mascle i les variables relacionades amb la qualitat de l'ejaculat (presència d'orina i restes de carbonat càlcic a l'ejaculat), la motilitat espermàtica individual, el pH del semen i el criteri d'idoneïtat de l'ejaculat per a ser utilitzat en IA (que resulta de la combinació subjectiva de varis caràcters de qualitat seminal i de l'ejaculat) van resultar ser poc heretables, però repetibles. Això indica que les pràctiques de maneig serien més aconsellables que la selecció genètica per a la millora del comportament dels mascles en els centres d'IA en termes de qualitat seminal i libido. Tanmateix, l'heretabilitat $\left(\mathbf{h}^{2}\right)$ dels caràcters de producció seminal (la concentració espermàtica, el volum i el nombre total d'espermatozous de l'ejaculat) va ser moderada, suggerint que la millora per selecció genètica d'aquests caràcters podria ser efectiva. Es va trobar una correlació genètica $\left(\mathbf{r}_{\mathrm{g}}\right)$ negativa entre el volum de l'ejaculat i la concentració espermàtica. Per tant, el número total d'espermatozous seria el caràcter més interessant pel que seleccionar.

L'estima de l'h ${ }^{2}$ obtinguda per a l'ADG va ser moderada i/o baixa. Aquest caràcter va presentar una baixa i positiva $\mathrm{r}_{\mathrm{g}} \mathrm{amb}$ la concentració espermàtica alhora que una baixa i negativa $\mathrm{r}_{\mathrm{g}} \mathrm{amb}$ 
el volum de l'ejaculat, mentre que no estigué genèticament correlacionat amb la resta dels caràcters analitzats. Per tant, es pot concloure que la selecció per a la millora de l'ADG en les línees paternals de conill no sembla que provoqui un efecte negatiu ni en la libido del mascle ni en els caràcters de qualitat seminal analitzats. De la mateixa manera, la repercussió que pugui tenir la selecció genètica per creixement en els caràcters de producció seminal també serà petita o quasi inexistent.

L’objectiu del capítol 2 va ser explorar la possibilitat d'una selecció indirecta de la contribució del mascle en la fertilitat mitjançant l'ús del pH del semen. Entre diferents caràcters seminals, es va proposar el pH del semen per que està considerat un indicador global de la expressió d'alguns caràcters de qualitat seminal i és senzill, ràpid i poc costós de mesurar. La relació entre la fertilitat del mascle (definida com l'èxit o el fracàs de la IA) i el pH dels ejaculats obtinguts per mascle i dia es va analitzar fent servir diversos models: 1) ignorant les correlacions genètiques i ambientals entre ambdós caràcters així i com incloent el pH com una covariable o com un factor categòric en el model de la fertilitat, 2) amb un model mixte bicaràcter, 3) o amb models mixtes recursius bicaràcter. En una granja comercial es varen inseminar femelles creuades amb semen provinent de mascles de línea paternal. Es va trobar un efecte negatiu gairebé lineal del pH del semen en la fertilitat. Els valors obtinguts de les $\mathrm{h}^{2}$ del pH del semen i de la fertilitat del mascle varen ser aproximadament 0.18 i 0.10 en tots els models, respectivament. La $r_{g}$ entre ambdós caràcters va ser negativa en els models on es va estimar, però, en tots els casos, l'interval mínim de màxima densitat al 95\% inclogué el 0 . Es va obtenir una bona predicció de les dades de fertilitat en tots els models i la correlació entre els valors additius predits (EBV, estimated breeding value) per fertilitat en els diferents models va ser propera a 1. Per tant, tot i que els models eren de diferent complexitat, no es varen obtenir resultats diferents considerant, o no considerant, correlacions genètiques i ambientals entre el pH i la fertilitat del mascle i assumint, o no assumint, recursivitat entre ambdós caràcters. Això pot ser degut a que l'efecte del pH sobre la fertilitat no és prou gran però a la baixa precisió obtinguda en les estimes dels paràmetres. D'aquest capítol es pot concloure que el pH del semen pot ser un caràcter interessant per a seleccionar els ejaculats per a ser utilitzats en inseminació per tal d'incrementar-ne la fertilitat de les dosis produïdes. Tanmateix, no sembla recomanable l'ús del pH del semen com un criteri de selecció per la millora genètica de la fertilitat del mascle per selecció indirecta.

En el capítol 3, es varen analitzar conjuntament les contribucions del mascle i de la femella en la fertilitat mitjançant dos models diferents: el model llindar additiu i el model llindar producte, ambdós adequats per l'anàlisi de dades de fertilitat binàries. El model llindar additiu proposa que la variable subjacent de la fertilitat és el resultat de la suma dels efectes genètics i ambientals dels dos individus que intervenen en l'aparellament, mentre que el model llindar producte assumeix que el resultat d'un aparellament és el resultat del producte de dues 
variables inobservades corresponents a les fertilitats dels dos individus involucrats en el creuament. L'habilitat predictiva dels dos models, avaluada en un conjunt independent de dades de fertilitat, va ser similar. Per exemple, el percentatge de prediccions errònies va ser del $28 \%$ en ambdós models Els models tampoc varen diferir en els valors obtinguts de l'error quadràtic mitjà de la predicció, ni en la sensibilitat ni en l'especificitat de la predicció, així i com tampoc en els valors positius i negatius predits. El model llindar producte permet calcular les probabilitats d'èxit de la fertilitat per a cada sexe alhora que també permet avaluar quin dels sexes és el responsable d'un fracàs en la inseminació. Les probabilitats d'obtenir un èxit en fertilitat varen ser semblants i elevades en el mascle i en la femella (87\% i 83\%, respectivament) i el percentatge d'errors d'inseminació atribuïts específicament al mascle i a la femella fou 39\% i 54\%, respectivament. Malgrat que les estimes de la $\mathrm{r}_{\mathrm{g}}$ entre la fertilitat del mascle i la fertilitat de la femella varen ser imprecises, aquestes foren similars en els dos models: 0.21 i 0.31 per al model producte i per l'additiu, respectivament. Tanmateix, algunes de les estimes obtingudes amb el model llindar producte (per exemple $\mathrm{l}^{\prime} \mathrm{h}^{2} \mathrm{i}$ els components de variància) no són pròpiament comparables amb les corresponents estimes obtingudes amb el model llindar additiu. $\mathrm{L}^{\prime} \mathrm{h}^{2}$ de la contribució del mascle en la fertilitat fou 0.17 i 0.04 en el model producte i en l'additiu, respectivament. Les correlacions entre els EBV obtinguts per a la fertilitat del mascle i la femella ens ambdós models varen ser properes a 1 i el percentatge d'animals en comú en el 10\% dels millors/pitjors animals ordenats per la predicció del seu valor additiu va ser alt (més del 76\%). Per tant, des del punt de vista de la selecció, els canvis que es produirien al fer servir un o altre model per l'avaluació dels animals per fertilitat serien petits.

En estudis previs en que s'ha avaluat el comportament reproductiu (fertilitat i prolificitat) en munta natural s'ha observat que la contribució del mascle és pràcticament nul-la. El capítol 4 té com a objectiu determinar si és possible detectar una major contribució del mascle a la fertilitat i a la prolificitat utilitzant unes condicions d'IA més limitants, tals com l'ús una concentració espermàtica més baixa en la dosi d'inseminació, fer una menor o nul·la preselecció dels ejaculats per qualitat seminal, o aplicar un període de conservació de la dosi més llarg. Per tant, en aquest capítol, es va determinar l'existència d'una possible interacció entre el genotip del mascle i les condicions d'IA per a la contribució del mascle en la fertilitat i en la prolificitat. La fertilitat (definida com l'èxit o el fracàs després de la IA) i la prolificitat (definida com el nombre total de catxaps nascuts per part) varen ser analitzades en dos conjunts d'anàlisis independents. L'existència de la interacció va ser determinada mitjançant l'ús del Character State Model, model en el que les mesures fenotípiques en els diferents ambients s'analitzen com a caràcters diferents. En un primer lloc, les condicions d'inseminació foren determinades exclusivament per la concentració espermàtica utilitzada en la dosi d'inseminació (10 o 40 milions d'espermatozous per $\mathrm{mL}$ ). Seguidament, les diferents 
condicions varen ser determinades pel conjunt de tots els factors implicats en el procés d'IA (condicions i durada del període de conservació de les dosis, el genotip de la femella i les condicions ambientals de la granja). Es va fer servir un model llindar mixte bicaràcter i un model lineal mixte per a l'anàlisi de la fertilitat i la prolificitat, respectivament. La concentració espermàtica de la dosi va tenir un clar efecte tant en la fertilitat com en la prolificitat, afavorint la concentració de la dosi d'IA més elevada (+0.13\% i +1.25 catxaps nascuts, respectivament). La prolificitat va ser més sensible a la reducció del nombre d'espermatozous en la dosi d'IA que la fertilitat. L'h ${ }^{2}$ de per a la contribució del mascle a la fertilitat va ser de 0.09 per ambdós tipus de concentracions espermàtiques de la dosi i 0.08 i 0.06 per a la prolificitat del mascle utilitzant alta i baixa concentració, respectivament. No es va trobar interacció entre el genotip del mascle i el tipus de concentració de la dosi d'IA. Per tant, obtindríem la mateixa resposta a la selecció si seleccionéssim per la millora del comportament reproductiu del mascle en qualsevol de les concentracions espermàtiques analitzades. Per un altre costat, podria existir una interacció entre el genotip del mascle i les condicions d'IA per a la contribució del mascle a la fertilitat i la prolificitat, tals com el temps i les condicions de conservació de la dosi, el genotip de la femella o l'ambient. Podria existir un efecte d'escala ja que les magnituds de les variàncies genètiques del mascle per aquests caràcters després de la inseminació en els dos tipus de condicions eren diferents. Addicionalment, la classificació dels animals en funció dels seus valors additius predits per aquests caràcters podria ser diferent depenent de les condicions d'IA utilitzades doncs les $r_{\mathrm{g}}$ obtingudes per a la fertilitat i la prolificitat en els dos tipus de condicions d'IA podrien ser diferents d'1 (la probabilitat d'obtenir una $\mathrm{r}_{\mathrm{g}}<0.75$ va ser del $83 \%$ per a la fertilitat i del $100 \%$ per a la prolificitat). La existència d'aquesta interacció també implicaria que es podrien escollir les condicions d'IA que donen el major progrés genètic per aquests caràcters amb la finalitat d'optimitzar el programa de millora per al comportament reproductiu del mascle per a unes determinades condicions d'utilització del semen.

Finalment, el darrer capítol d'aquesta tesi ha tractat de determinar quins són els períodes crítics entorn el moment de la IA en els que la temperatura ambiental té un major efecte en les contribucions del mascle i de la femella a la fertilitat. Per assolir aquest objectiu, s'ha utilitzat el model llindar producte car permet obtenir estimes dels factors que afecten específicament a cadascun dels dos membres que intervenen en un procés d'IA. Es varen utilitzar dades d'IA d'animals de línea paternal i registres de temperatura interior de la granja on aquests varen estar allotjats. S'empraren com a descriptors de temperatura el promig de la temperatura màxima diària i la proporció de dies del període en que la temperatura màxima sobrepassava els $25^{\circ} \mathrm{C}$. Aquests descriptors varen ser calculats per a diferents períodes al voltant del dia de la inseminació. En el cas dels mascles, es varen triar 4 periodes per a cobrir diferents estadis de l'espermatogènesi, el transport epididimari dels espermatozous i el dia de la inseminació i 
fertilització. Per a les femelles, es varen escollir cinc períodes per tal de cobrir les fases de la maduració fol-licular prèvies a la ovulació, el dia de la inseminació i el moment de la ovulació, l'estadi peri-implantacional dels embrions, l'estadi embrionari i d'inici de l'estadi fetal de la gestació i, finalment, la darrera fase de gestació fins al dia del part. Els efectes dels diferents descriptors de temperatura es varen estimar en les corresponents variables subjacents de la fertilitat del mascle i de la femella en un conjunt de models llindar producte. La temperatura del dia de la inseminació va ser el descriptor de temperatura amb un efecte més rellevant sobre la fertilitat del mascle: altes temperatures en el dia d'inseminació causaren una reducció en la seva fertilitat (representant una pèrdua del $6 \%$ de fertilitat respecte la temperatura de termo-neutralitat). Desviacions de la temperatura de confort en els descriptors dels períodes previs a la inseminació fins als inicis de la gestació varen tenir un efecte negatiu en la fertilitat de la femella, essent especialment sensible el període peri-implantacional dels embrions (representant una pèrdua de 5-6\% en la fertilitat del femella en comparació a la temperatura de confort). El període final de la gestació no es va veure afectat per la temperatura. Podem concloure que el model llindar producte permet estimar que el mascle i la femella es veuen afectats per la temperatura en diferents períodes al voltant del dia de la inseminació. Tanmateix, la magnitud i la persistència de les temperatures assolides en les condicions comercials d'aquest estudi no semblen tenir un gran efecte sobre les fertilitats del mascle i de la femella 


\section{Resumen}

El objetivo principal de esta tesis ha sido analizar las fuentes de variación de algunos de los componentes que intervienen en la producción de dosis fértiles para su uso en inseminación artificial (IA). El análisis de estos componentes tiene como finalidad explorar el posible interés y las limitaciones del uso de diferentes estrategias de selección para su mejora genética en una línea paternal de conejos seleccionada por velocidad de crecimiento. Estos componentes incluyen tanto caracteres de producción y calidad seminal como el comportamiento reproductivo del macho. Considerando éste último como la expresión final conjunta del efecto de los caracteres de calidad seminal y el efecto de la interacción entre ellos y la hembra.

En todos los estudios se han utilizado modelos mixtos umbrales y lineales bajo una aproximación Bayesiana.

En el capítulo 1, se estimaron los parámetros genéticos de la libido del macho y de las características seminales involucradas en el criterio utilizado para la determinación de la idoneidad de los eyaculados para ser utilizados en inseminación. También se determinó la relación genética de todos estos caracteres con la velocidad de crecimiento (ADG, average daily gain). La concentración espermática, el volumen del eyaculado y ADG se analizaron conjuntamente utilizando un modelo lineal tricarácter. Cada uno de los otros caracteres se analizó junto con ADG utilizando modelos umbrales o lineales bicarácter.

La cantidad de eyaculados descartados para su uso inseminación fue elevada (38\% respecto del total de eyaculados recogidos). La razón principal de eliminación fue la baja motilidad espermática individual. La libido del macho y las variables relacionadas con la calidad del eyaculado (presencia de orina y restos de carbonato cálcico en el eyaculado), la motilidad espermática individual, el $\mathrm{pH}$ del semen y el criterio de idoneidad del eyaculado para ser utilizado en IA (que resulta de la combinación subjetiva de varios caracteres de calidad seminal y del eyaculado) fueron poco heredables, pero repetibles. Esto indica que las prácticas de manejo serian más aconsejables que la selección genética para mejorar el comportamiento de los machos en los centros de IA en cuanto a su calidad seminal y libido. Sin embargo, la heredabilidad $\left(\mathbf{h}^{2}\right)$ de los caracteres de producción seminal (la concentración espermática, el volumen y el número total de espermatozoides del eyaculado) fue moderada, sugiriendo que la mejora por selección genética de estos caracteres podría ser efectiva. Sin embargo, la correlación genética $\left(\mathbf{r}_{\mathrm{g}}\right)$ entre el volumen del eyaculado y la concentración espermática fue negativa. Por lo tanto, el número total de espermatozoides seria el carácter más interesante por el que seleccionar.

La estima de la $\mathrm{h}^{2}$ obtenida para la ADG fue de moderada a baja. Éste carácter presenta una baja y positiva $r_{g}$ con la concentración espermática a la vez que una baja y negativa $r_{g}$ con el 
volumen del eyaculado, mientras que no está genéticamente correlacionada con el resto de los caracteres analizados. Consecuentemente, se puede concluir que la selección para la mejora de la ADG en las líneas paternales de conejo no parece que vaya a provocar un efecto negativo ni en la libido del macho ni en los caracteres de calidad seminal analizados. Del mismo modo, la repercusión que pueda tener la selección genética por crecimiento sobre los caracteres de producción seminal también será pequeña o casi inexistente.

El objetivo del capítulo 2 fue explorar la posibilidad de la selección indirecta de la contribución del macho en la fertilidad mediante el uso del pH del semen. Entre diferentes caracteres seminales, se propuso el pH del semen porque está considerado un indicador global de la expresión de algunos caracteres de calidad seminal y es sencillo, rápido y poco costoso de medir. La relación entre la fertilidad del macho (definida como el éxito o el fracaso tras la IA) y el pH de los eyaculados obtenidos de un mismo macho y día se analizarom utilizando diversos modelos: 1) ignorando las correlaciones genéticas y ambientales existentes entre ambos caracteres así como incluyendo el pH como una covariable o como un factor categórico en el modelo de la fertilidad, 2) con un modelo mixto bicarácter, 3) o con modelos mixtos recursivos bicarácter. En una granja comercial se inseminaron hembras cruzadas con semen procedente de machos de línea paternal. Se encontró un efecto negativo prácticamente lineal del pH del semen en la fertilidad. Los valores obtenidos de la $\mathrm{h}^{2}$ del $\mathrm{pH}$ del semen y de la fertilidad del macho fueron aproximadamente 0.18 y 0.10 en todos los modelos, respectivamente. La $r_{g}$ entre ambos caracteres fue negativa en aquellos modelos en los que se estimó. Sin embargo, el 0 estuvo incluido en el intervalo mínimo de máxima densidad al 95\% en todos los modelos. Se obtuvo una buena predicción de los datos de fertilidad en todos los modelos y la correlación entre los valores aditivos predichos (EBV, estimated breeding value) para fertilidad entre los diferentes modelos fue cercana a 1. Por lo tanto, aunque los modelos diferían en complejidad, no se obtuvieron resultados diferentes considerando, o no considerando, correlaciones genéticas y ambientales entre el pH y la fertilidad del macho y asumiendo, o no asumiendo, recursividad entre ambos caracteres. Esto puede ser debido a que el efecto del pH sobre la fertilidad no es lo suficientemente grande y a la baja precisión que se ha obtenido de las estimas de los parámetros. De éste capítulo se puede concluir que el pH del semen puede ser un carácter interesante para seleccionar los eyaculados que van a ser utilizados en inseminación con la finalidad de incrementar la fertilidad de les dosis producidas. Sin embargo, no parece recomendable el uso del pH del semen como criterio de selección para la mejora genética de la fertilidad del macho por selección indirecta.

En el capítulo 3, se analizaron conjuntamente les contribuciones del macho y de la hembra a la fertilidad mediante el uso de dos modelos diferentes: el modelo umbral aditivo y el modelo umbral producto, ambos adecuados para el análisis de datos de fertilidad binarios. El modelo umbral aditivo propone que la variable subyacente de la fertilidad es el resultado de la suma 
de los efectos genéticos y ambientales de los dos individuos que intervienen en el apareamiento, mientras que el modelo umbral producto propone que el resultado de un apareamiento es el resultado del producto de dos variables inobservadas que son las fertilidades de los dos individuos involucrados en el apareamiento. La habilidad predictiva de los dos modelos fue similar cuando se evaluó en un conjunto independiente de datos. Por ejemplo, el porcentaje de predicciones erróneas fue del $28 \%$ en ambos modelos. Los modelos tampoco difirieron en los valores obtenidos para el error cuadrático medio de la predicción, ni en la sensibilidad ni en la especificidad de la predicción, así y como tampoco en los valores positivos y negativos predichos. El modelo umbral producto permite el cálculo de las probabilidades de éxito de la fertilidad de cada sexo y también permite evaluar cuál de los dos sexos es el responsable de un fracaso en la inseminación. Las probabilidades de obtener un éxito en fertilidad para el macho y la hembra fueron parecidas y elevadas (87\% y 83\%, respectivamente) y el porcentaje de errores de inseminación atribuibles específicamente al macho y a la hembra fueron del 39\% y 54\%, respectivamente. A pesar de que las estimas de la $r_{g}$ entre la fertilidad del macho y la fertilidad de la hembra fueron imprecisas, estas fueron similares en los dos modelos: 0.21 y 0.31 para el modelo producto y para el aditivo, respectivamente. Sin embargo, algunas de les estimas obtenidas con el modelo umbral producto (por ejemplo la $\mathrm{h}^{2} \mathrm{y}$ los componentes de varianza) no son propiamente comparables con las correspondientes estimas obtenidas con el modelo umbral aditivo. La $\mathrm{h}^{2}$ para la contribución del macho a la fertilidad fue 0.17 y 0.04 con el modelo producto y el aditivo, respectivamente. La correlación entre los EBV obtenidos para la fertilidad del macho y de la hembra en ambos modelos fue cercana a 1 y el porcentaje de animales en común en el 10\% de los mejores/peores animales ordenados por la predicción de su valor aditivo fue elevado (más del 76\%) en ambos modelos. Por lo tanto, desde el punto de vista de la selección, los cambios que se producirían en la evaluación de los animales por fertilidad derivados de utilizar uno u otro modelo serian pequeños.

Estudios previos en los que se ha evaluado el comportamiento reproductivo (fertilidad y prolificidad) tras la monta natural se ha observado que la contribución del macho es prácticamente nula. El capítulo 4 tuvo como objetivo determinar si es posible detectar una mayor contribución del macho a la fertilidad y a la prolificidad bajo unas condiciones de IA más limitantes, tales como el uso de una concentración espermática menor en la dosis de inseminación, realizar una menor o nula pre-selección de los eyaculados por calidad seminal, o aplicar un período de conservación de la dosis más largo). Por lo tanto, en éste capítulo, se determinó la existencia de una posible interacción entre el genotipo del macho y las condiciones de IA para la contribución del macho en la fertilidad y en la prolificidad. La fertilidad (definida como el éxito o el fracaso tras la IA) y la prolificidad (definida como el número total de gazapos nacidos por parto) fueron analizados en dos conjuntos de análisis 
independientes. La existencia de interacción fue determinada mediante el uso del Character State Model, modelo en el que las medidas fenotípicas en los diferentes ambientes son analizadas como caracteres distintos. En un primer lugar, las condiciones de inseminación fueron determinadas exclusivamente por la concentración espermática utilizada en la dosis de inseminación (10 o 40 millones de espermatozoides por mL). Seguidamente, las diferentes condiciones fueron determinadas por el conjunto de todos los factores implicados en el proceso de IA (condiciones y duración del período de conservación de las dosis, el genotipo de la hembra y las condiciones ambientales de la granja). Se utilizó un modelo umbral mixto bicarácter y un modelo lineal mixto bicarácter para el análisis de la fertilidad y la prolificidad, respectivamente. La concentración espermática de la dosis tuvo un claro efecto tanto en la fertilidad como en la prolificidad, favoreciendo la concentración de la dosis de IA más elevada $(+0.13 \%$ y +1.25 gazapos nacidos, respectivamente). La prolificidad fue más sensible a la reducción en el número de espermatozoides en la dosis de IA que la fertilidad. La $\mathrm{h}^{2}$ para la fertilidad del macho fue de 0.09 para ambos tipos de concentraciones espermáticas de la dosis y 0.08 y 0.06 para la prolificidad del macho utilizando alta y baja concentración, respectivamente. No se encontró interacción entre el genotipo del macho y el tipo de concentración de la dosis de IA. Por lo tanto, se obtendría la misma respuesta a la selección en caso de seleccionar para la mejora del comportamiento reproductivo del macho con el uso de cualquiera de las concentraciones espermáticas analizadas. Per otro lado, podría existir una interacción entre el genotipo del macho y las condiciones de IA para la contribución del macho en la fertilidad y en la prolificidad, tales como el tiempo y las condiciones de conservación de la dosis, el genotipo de la hembra o el ambiente. Podría existir un efecto de escala ya que las magnitudes de las varianzas genéticas del macho para estos caracteres tras la inseminación en los dos tipos de condiciones eran diferentes. Adicionalmente, la clasificación de los animales por la predicción de sus valores aditivos para estos caracteres podría ser diferente en función de las condiciones de IA porque las $r_{g}$ obtenidas para la fertilidad y la prolificidad en los dos tipos de condiciones de IA podrían ser diferentes de 1 (la probabilidad de obtener una $\mathrm{r}_{\mathrm{g}}<$ 0.75 fue del $83 \%$ para la fertilidad y del 100\% para la prolificidad). La existencia de ésta interacción también implicaría que sería posible escoger las condiciones de IA que proporcionan el mayor progreso genético para estos caracteres con la finalidad de optimizar el programa de mejora para el comportamiento reproductivo del macho para unas determinadas condiciones de uso del semen.

Finalmente, el último capítulo de esta tesis ha tratado de determinar cuáles son los períodos críticos entorno al momento de la IA en los que la temperatura ambiental tiene un mayor efecto en las contribuciones del macho y de la hembra para la fertilidad. Para conseguir éste objetivo, se utilizó el modelo umbral producto porque permite obtener estimas de los factores que afectan específicamente a cada uno de los dos miembros que intervienen en un proceso de 
IA. Se utilizaron datos de IA de animales de línea paternal y registros de temperatura interior de la granja donde estos estuvieron alojados. Como descriptores de temperatura, se utilizaron el promedio de la temperatura máxima diaria y la proporción de días del período en que la temperatura máxima fue superior de $25^{\circ} \mathrm{C}$. Estos descriptores fueron calculados en diferentes periodos entorno al día de la inseminación. Para los machos, se escogieron cuatro periodos que cubren diferentes estadios de la espermatogénesis, el transporte epididimario de los espermatozoides y el día de la inseminación y fertilización. Para las hembras, se escogieron cinco periodos para cubrir las fases de la maduración folicular previas a la ovulación, el día de la inseminación y el momento de la ovulación, la fase peri-implantacional de los embriones, la fase embrionaria y el inicio de la fase fetal de la gestación y, finalmente, la última fase de gestación hasta el día del parto. Los efectos de los diferentes descriptores de temperatura se estimaron en las correspondientes variables subyacentes de la fertilidad del macho y de la hembra en un conjunto de modelos umbral producto. La temperatura del día de la inseminación fue el descriptor de temperatura con un efecto más relevante sobre la fertilidad del macho: altas temperaturas en el día de inseminación causaron una reducción en su fertilidad (representando una pérdida del 6\% de fertilidad con respecto a la temperatura de confort). Desviaciones de la temperatura de confort en los descriptores de los períodos previos a la inseminación hasta los inicios de la gestación tuvieron un efecto negativo en la fertilidad de la hembra, siendo especialmente sensible el período peri-implantacional de los embriones (representando una pérdida del 5-6\% en la fertilidad de la hembra con respecto a la temperatura de confort). El período final de la gestación no se vio afectado per la temperatura. Se puede concluir que el modelo umbral producto permite estimar que el macho y la hembra se ven afectados por la temperatura en períodos diferentes alrededor del día de la inseminación. Sin embargo, la magnitud y la persistencia de las temperaturas que se alcanzaron en las condiciones de granja de éste estudio no parecen tener un gran efecto sobre las fertilidades del macho y de la hembra 


\section{Contents}

Index of Tables

1.1 Components of the production of fertile doses ........................................... 13

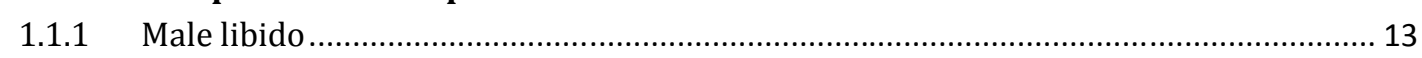

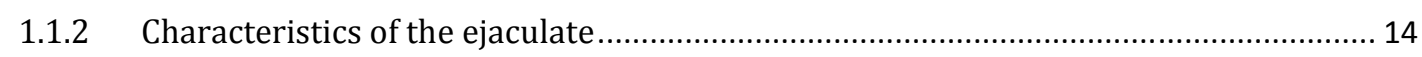

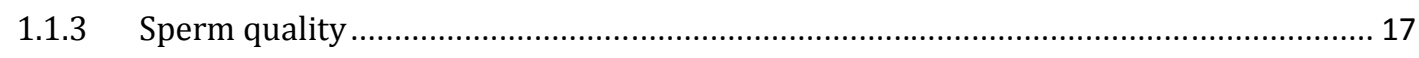

1.1.4 Tests analyzing possible molecular indicators of fertility ............................................ 24

1.1.5 Predicting fertilizing potential of ejaculates through seminal traits .......................... 24

1.1.6 Male reproductive performance ......................................................................... 26

1.2 Factors of variation of the production of fertile doses......................................... 29

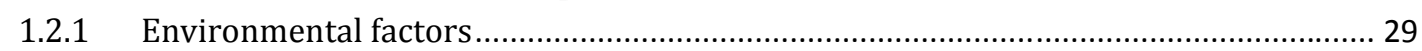

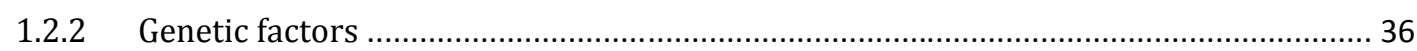

1.2.3 Genotype $\mathrm{x}$ AI conditions interaction for male effect on reproductive performance... 45

1.3 The relationship between growth rate and the traits involved in the production

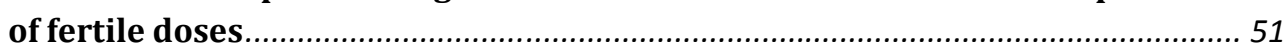

1.4 Methods and models for the analyses of seminal traits and fertility ................. 53

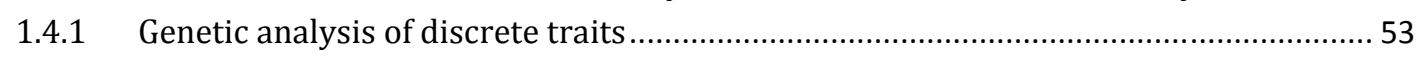

1.4.2 Models for the analysis of longitudinal data ............................................................ 57

1.4.3 Models for the joint analysis of seminal and reproductive performance traits ........... 59

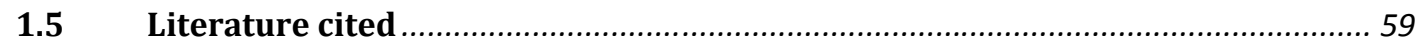

Chapter one Genetic basis of semen traits and their relationship with growthrate in rabbits ................................................................................... 75

Chapter two Different ways to model biological relationships between fertility and $\mathbf{p H}$ of the semen in rabbits......................................................... 99

Chapter three Product versus additive model for studying artificial insemination results in several livestock species: Rabbits ........................... 121

Chapter four Interaction of genotype $\times$ artificial insemination conditions for male effect on fertility and prolificacy.................................... 135

Chapter five Using the product threshold model for estimating separately the effect of temperature on male and on female fertility.................. 159 


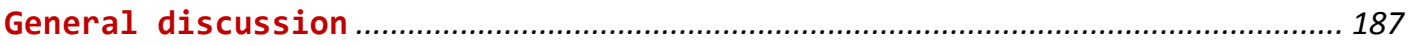

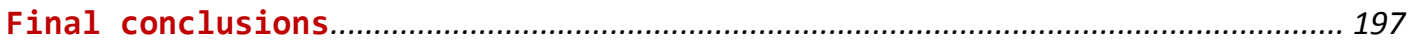

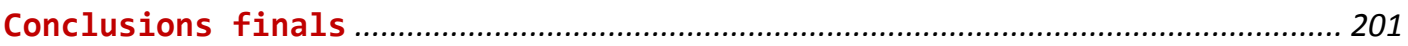

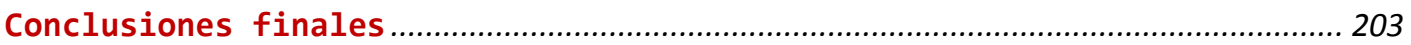

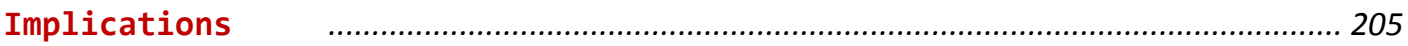

Appendix 


\section{Index of tables}

\section{Chapter one}

Table 1.1. Summary statistics of average daily gain and seminal traits expressed as average percentage per buck

Table 1.2. Mean (Highest posterior density interval at $95 \%$ in brackets, and Monte Carlo standard error in parentheses) of the marginal distribution of heritability $\left(\mathrm{h}^{2}\right)$, phenotypic variance $\left(\sigma^{2}\right)$, ratio of variance of male permanent $(\mathrm{pm})$ and common litter (c) environmental effects to phenotypic variance for average daily gain and seminal traits.

\section{Chapter two}

Table 2.1. Summary statistics of the cross-classified effect of pH (1 to 8 ) included in the fertility model.

Table 2.2. Structural coefficients $\left(\lambda_{F e r t<p H}\right)$ and (co)variance component matrices for the male additive effects $(\mathbf{G})$, the male non additive plus environmental permanent effects $\left(\mathbf{P}_{\mathbf{m}}\right)$, the female effects $\left(\mathbf{P}_{\mathbf{f}}\right)$ and the environmental permanent effects of male and day of AI $\left(\mathbf{P}_{\mathbf{m d}}\right)$ for the $\mathrm{pH}$ of the semen $(\mathrm{pH})$ and fertility (Fert) assumed in the different models

109

Table 2.3. Means (SD) of the posterior distributions of the recursive effect of the $\mathrm{pH}$ in the liability of fertility. Being $\lambda$ and $\lambda_{i}$ (for $i=1, \ldots 8$ ) a covariate or as a cross-classified effect

Table 2.4. Medians (highest posterior density interval at 95\%) of the posterior distributions of the phenotypic variance $\left(\sigma^{2}\right)$ phenotypic correlation $(r)$, male heritability $\left(h^{2}\right)$, ratios of variance $\left(\mathrm{p}_{i}\right)$ and correlations $\left(\mathrm{r}_{i}\right)$ across the different models for semen $\mathrm{pH}$ and fertility (Fert) ${ }^{1}$

\section{Chapter three}

Table 3.1. Description of fertility data

Table 3.2. Predictive ability of the product and additive threshold models 129

Table 3.3. Posterior means and highest posterior density interval at $95 \%$ (in brackets) of the probability of success for the unobserved phenotypes, genetic and environmental variances, heritabilities, and correlation between breeding values obtained with the threshold and additive threshold model 130

\section{Chapter four}

Table 4.1. Summary statistics for fertility $\left(\mathrm{F}_{i}\right)$ and number of total kits born $\left(\mathrm{TB}_{i}\right)$ data across the three different types of AI doses $\left(i=10^{1}, 40^{2}, \mathrm{~N}^{3}\right)$.

Table 4.2. Definition and number of levels of fixed effects for fertility $\left(\mathrm{F}_{i}\right)$ and total number of kits born $\left(\mathrm{TB}_{i}\right)$ at different $\mathrm{AI}$ conditions $\left(i=10^{1}, 40^{2}, \mathrm{EXP}^{3}, \mathrm{~N}^{4}\right)$ 
Table 4.3. Structure of the (co)variance matrices assumed for fertility and total number of kits born in the two groups of analysis ${ }^{1}$ 146

Table 4.4. Convergence diagnostic and summary statistics of the marginal posterior distributions of phenotypic variance $\left(\sigma^{2}\right)$, heritability $\left(h^{2}\right)$, and ratios of variation attributable to the male nonadditive genetic plus permanent environmental effects $\left(\mathrm{p}_{m}\right)$, the female effects $\left(\mathrm{p}_{f}\right)$, and the permanent environmental effects of male and day of $\mathrm{AI}\left(\mathrm{p}_{m d}\right)$ for fertility $\left(\mathrm{F}_{i}\right)$ and total number of kids born $\left(\mathrm{TB}_{i}\right)$ with different $\mathrm{AI}$ conditions $\left({ }_{i}=10^{1}, 40^{2}\right)$ 149

Table 4.5. Convergence diagnostic and summary statistics of the marginal posterior distribution of genetic correlation $\left(\mathrm{r}_{\mathrm{g}}\right)$ and variance of the genotype per type of AI dose interaction $\left(\sigma^{2} \mathrm{G \times E}\right)$ for fertility $\left(\mathrm{F}_{i}\right)$ and total number of kids born $\left(\mathrm{TB}_{i}\right)$ at different AI conditions $\left(i=10,{ }^{1} 40,{ }^{2} \mathrm{EXP}^{3}{ }^{3} \mathrm{~N}^{4}\right)$

Table 4.6. Convergence diagnostic and summary statistics of the marginal posterior distributions of phenotypic variance $\left(\sigma^{2}\right)$, heritability $\left(\mathrm{h}^{2}\right)$, and ratios of variation attributable to the male nonadditive genetic plus permanent environmental effects $\left(\mathrm{p}_{m}\right)$, the female effects $\left(\mathrm{p}_{f}\right)$, and the permanent environmental effects of male and day of $\mathrm{AI}\left(\mathrm{p}_{m d}\right)$ for fertility $\left(\mathrm{F}_{i}\right)$ and total number of kids born $\left(\mathrm{TB}_{i}\right)$ with different $\mathrm{AI}$ conditions $\left(i=\mathrm{EXP},{ }^{1} \mathrm{~N}^{2}\right)$

\section{Chapter five}

Table 5.1. Distribution of AI data and maximum temperature in the AI day 165

Table 5.2. Different product threshold models including several temperature descriptors in the male and the female liabilities of fertility ( $\boldsymbol{\beta}_{\odot}$ and $\boldsymbol{\beta}_{\varphi}$, respectively).

Table 5.3. Correlations among the different temperature descriptors used to estimate the effect of thermal stress in male and female fertility. Term avgTmax_i_j_k is used to denote the average of maximum temperatures during a period that lasts from day $i$ to day $j$ for the male or female $(k)$. Term DI_i_j_k is used to denote the male or female temperature descriptor of proportion of days of the period from the $i$ to the $j$ day in which the maximum temperature was above $25^{\circ} \mathrm{C}$. Term Tmax_0_ $k$ denotes the male and female maximum temperature of the AI day. 171 


\section{Index of figures}

\section{Literature review}

Figure I.1. Doe and artificial vagina disposition to perform ejaculate collection. 13

Figure I.2. Counting chamber Thoma for determining sperm concentration. 15

Figure I.3. Nucleocounter SP-100 (Chemometec, Allerod, Denmark) for determining sperm .16

Figure I.4. Image of rabbit sperm motility pattern obtained with CASA system (from UAB: unpublished images). 18

Figure I.5. Eosin-nigrosin staining for the determination of rabbit sperm viability. Normal live sperm exclude the eosin stain and appear white in color, whereas "dead" sperm (i.e. those with loss of membrane integrity) take up eosin and appear pinkish in color (from: IRTA unpublished images).

Figure I.6. Different rabbit sperm abnormalities (from: IRTA unpublished images) .20

Figure I.7. Acrosome status of rabbit spermatozoa using FITC-Pisum sativum lectin (FITCPSA) (from: UAB unpublished images).

Figure I.8. From Enciso et al. 2006. DNA fragmentation of men sperm determined with the sperm chromatin dispersion (SCD) test using the Halosperm ${ }^{\circledR}$ kit. Sample only showing a sperm nucleus with fragmented DNA in the microscopic field, evidenced by the absence of halo.

Figure I.9.From ejaculate collection to parity: A) artificial vaginas in the oven, B) bucks room, C) buck mounting the artificial vagina, D) ejaculate in the collection tube, E) semen samples in the hot plate, $\mathrm{F}$ and $\mathrm{G}$ ) microscopical evaluation of the seminal samples, $\mathrm{H}$ ) Determination of the sperm concentration of the pool of semen suitable for AI, I) Filling up the heterospermic doses, J) AI doses in the temperature controlled semen storage box, K) doe insemination in the farm, L) litter born after AI.

Figure I.10. Ratio between correlated (CR) and direct response (DR) and the correlated response in standard deviation units $(\mathrm{CR} / \sigma)$ under different hypothetic scenarios of genetic correlation $\left(\mathrm{r}_{\mathrm{g}}\right)$ and heritability of the seminal trait $\left(\mathrm{h}_{\mathrm{s}}{ }_{\mathrm{s}}\right)$ and male fertility $\left(\mathrm{h}^{2} \mathrm{~F}\right)$

Figure I.11. Hypothetic dose-response curve of fertility as a function of the number of total sperm (adapted from: Amann and Hammerstedt, 2002).

Figure I.12. Four types of phenotypic response (P) of 3 individuals across an environmental variation $(\mathrm{E})$. 


\section{Chapter one}

Figure 1.1. Relative importance of several causes of ejaculate rejection for AI: presence of urine (Ur), presence of calcium carbonate deposits (Ca) and individual motility score less than or equal to $2(\mathrm{IM} \leq 2)$ in a subjective scale from 0 to 5 corresponding to a percentage of sperm showing progressive movement of: 0 to 10,11 to 25,26 to 50,51 to 70,71 to 90 , or 91 to $100 \%$, respectively.

Figure 1.2. Estimated marginal posterior distributions of the genetic $\left(r_{g}().\right)$, male non-additive genetic permanent environmental $\left(\mathrm{r}_{\mathrm{pm}}().\right)$ and phenotypic $\left(\mathrm{r}_{\mathrm{p}}().\right)$ correlation between average sperm concentration (Conc) and average volume (Vol) of the ejaculate on the day of collection.

Figure 1.3. Estimated marginal posterior distributions of the genetic correlation $\left(\mathrm{r}_{\mathrm{g}}().\right)$ between average daily gain during the fattening period (ADG) and the following seminal traits: male libido (Lib), presence of urine (Ur) and calcium carbonate deposits ( $\mathrm{Ca}$ ) in the ejaculate, semen $\mathrm{pH}$, individual motility score (IM), and suitability for AI (Sui) of the ejaculate, average sperm concentration (Conc), average volume (Vol), and average sperm production per ejaculate (Prod).

Figure 1.4. Estimated marginal posterior distributions of the male non-additive genetic permanent environmental correlation $\left(\mathrm{r}_{\mathrm{pm}}().\right)$ between average daily gain during the fattening period (ADG) and the following seminal traits: male libido (Lib), presence of urine (Ur) and calcium carbonate deposits ( $\mathrm{Ca}$ ) in the ejaculate, semen $\mathrm{pH}$, individual motility score (IM), and suitability for AI (Sui) of the ejaculate, average sperm concentration (Conc), average volume (Vol), and average sperm production per ejaculate (Prod)

Figure 1.5. Estimated marginal posterior distributions of the phenotypic correlation $\left(r_{p}().\right)$ between average daily gain during the fattening period (ADG) and the following seminal traits: male libido (Lib), presence of urine (Ur) and calcium carbonate deposits (Ca) in the ejaculate, semen $\mathrm{pH}$, individual motility score (IM), and suitability for AI (Sui) of the ejaculate, average sperm concentration (Conc), average volume (Vol), and average sperm production per ejaculate (Prod). Phenotypic correlation between ADG and binary traits (Lib, Ur, Ca and Sui) were based on liability scale...... 94

\section{Chapter two}

Figure 2.1. Effect of the $\mathrm{pH}$ on fertility in the observed scale in the different models for the $\mathrm{pH}$ of the semen and fertility: a mixed model without genetic and environmental correlations including the $\mathrm{pH}$ as a covariate or as cross-classified effect in the model of fertility (model $\mathrm{UMM}_{\text {cov }}$ and $\mathrm{UMM}_{\text {cross }}$, respectively), a bivariate mixed model $\left(\mathrm{BMM}_{0}\right)$, and a recursive mixed model including the $\mathrm{pH}$ as a covariate or as a cross-classified effect in the model of fertility (RMM cross $_{\text {and }} \mathrm{RMM}_{\text {cross, }}$ respectively). 112

Figure 2.2. Posterior predictive distributions of the mean of a fertility success $(E(\hat{y} \mid y=1))$ and the mean of a fertility failure data $(E(\hat{y} \mid \mathrm{y}=0))$ estimated in the following models for fertility and the $\mathrm{pH}$ of the semen: a mixed model without genetic and environmental correlations including the $\mathrm{pH}$ as a covariate or as cross-classified effect in the model of fertility (model $\mathrm{UMM}_{\mathrm{cov}}$ ), a bivariate mixed model $\left(\mathrm{BMM}_{0}\right)$, and a recursive mixed 
model including the $\mathrm{pH}$ as a cross-classified effect in the in the model of fertility $\left(\mathrm{RMM}_{\text {cross }}\right)$.

\section{Chapter four}

Figure 4.1. Estimated marginal posterior distribution of the difference between fertility in the observed scale $\left(\mathrm{F}_{i}\right)$ and total number of kits born $\left(\mathrm{TB}_{i}\right)$ at two different sperm concentration of the AI dose $\left(i=10^{1}, 40^{2}\right) .{ }^{1} 10=$ AI with 24 h stored doses with $10 \times 10^{6}$ spermatozoa/mL. ${ }^{2} 40=$ AI with 24 h stored doses with $40 \times 10^{6}$ spermatozoa $/ \mathrm{mL} . . .148$

Figure 4.2. Estimated marginal posterior distribution of ratio between fertility in the observed scale $\left(\mathrm{F}_{i}\right)$ and total number of kits born $\left(\mathrm{TB}_{i}\right)$ at two different sperm concentration of the AI dose $\left(i=10^{1}, 40^{2}\right) \cdot{ }^{1} 10=$ AI with 24 h stored doses with $10 \times 10^{6}$ spermatozoa/mL. ${ }^{2} 40=$ AI with 24 h stored doses with $40 \times 10^{6}$ spermatozoa $/ \mathrm{mL} . . .152$

\section{Chapter five}

Figure 5.1. Correspondences between the biological processes involved in fertilization (above the chronological line) and the different temperature descriptors used in the analyses for the male and female fertility (below the chronological line). Black and grey arrows refer to processes and temperature descriptors used for male and female, respectively. Term avgTmax_i_j_k is used to denote the average of maximum temperatures during a period that lasts from day $i$ to day $j$ for the male or female $(k)$. Term DI_i_j_k is used to denote the temperature descriptor of proportion of days of the period from the $i$ to the $j$ day in which the maximum temperature was above 25으 $\mathrm{C}$ for the male or female. Term Tmax_0_ $k$ denotes the male and female maximum temperature of the AI day for the male or female. 166

Figure 5.2. Panel A: Average maximum daily temperature recorded per month in the male and female building ( $\operatorname{Tmax}_{-}+$and $\operatorname{Tmax}_{-} \hat{O}$, respectively) and average percentage of fertility success per month (SE in bars). Panel B: Average daily temperature range recorded per month in the male and female building (Range_ $\hat{\sigma}$ and Range_o, respectively)

Figure 5.3. Posterior mean and highest posterior density interval at $95 \%$ of the effects on male fertility rate of the average maximum daily temperatures in the periods from 40 $\mathrm{d}$ to $21 \mathrm{~d}$ prior to $\mathrm{AI}$, from $20 \mathrm{~d}$ to $11 \mathrm{~d}$ prior to $\mathrm{AI}$ and from $10 \mathrm{~d}$ to $1 \mathrm{~d}$ prior to $\mathrm{AI}$ (avgTmax_40_20_ô, avgTmax_20_10_o and avgTmax_10_0_ô, respectively) and effect on male fertility rate of the maximum temperature the day of AI (Tmax_0_ß). Estimates of each figure were obtained in the models 1, 3, 5, and 7, respectively (detailed in Table 5.3). 175

Figure 5.4. Posterior mean and highest posterior density interval at $95 \%$ of the effects on male fertility rate of the percentage of days with maximum temperature higher than $25^{\circ} \mathrm{C}$ in the periods from $40 \mathrm{~d}$ to $21 \mathrm{~d}$ prior to $\mathrm{AI}$, from $20 \mathrm{~d}$ to $11 \mathrm{~d}$ prior to $\mathrm{AI}$ and

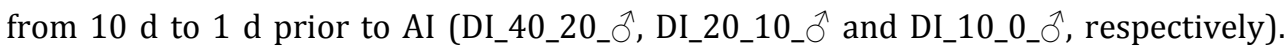
Estimates of each figure were obtained in the models 2, 4, and 6, respectively (detailed in Table 5.3) 176 
Figure 5.5. Posterior mean and highest posterior density interval at $95 \%$ of the effects on female fertility rate of the average maximum daily temperatures in the periods from $10 \mathrm{~d}$ to $1 \mathrm{~d}$ prior to AI, from $1 \mathrm{~d}$ to $7 \mathrm{~d}$ after $\mathrm{AI}$, from $8 \mathrm{~d}$ to $18 \mathrm{~d}$ after AI, and from $19 \mathrm{~d}$ to $31 \mathrm{~d}$ after AI (avgTmax_10_0_o, avgTmax_0_7_o, avgTmax_7_18_o and avgTmax_18_31_o, respectively) and effect on female fertility rate of the maximum temperature the day of AI (Tmax_0_o). Estimates of each figure were obtained in the models 5, 7, 1, 8, and 10, respectively (detailed in Table 5.3). 178

Figure 5.6. Posterior mean and highest posterior density interval at $95 \%$ of the effects on female fertility rate of the percentage of days with maximum temperature higher than $25^{\circ} \mathrm{C}$ in the periods from $10 \mathrm{~d}$ to $1 \mathrm{~d}$ prior to $\mathrm{AI}$, from $1 \mathrm{~d}$ to $7 \mathrm{~d}$ after $\mathrm{AI}$, from $8 \mathrm{~d}$ to 18 $\mathrm{d}$ after $\mathrm{AI}$ and from $19 \mathrm{~d}$ to $31 \mathrm{~d}$ after AI (DI_10_0_o, DI_0_7_o, DI_7_18_o and DI_18_31_o, respectively). Estimates of each figure were obtained in the models 6, 2, 9, and 11, respectively (detailed in Table 5.3). 


\section{General \\ introduction}

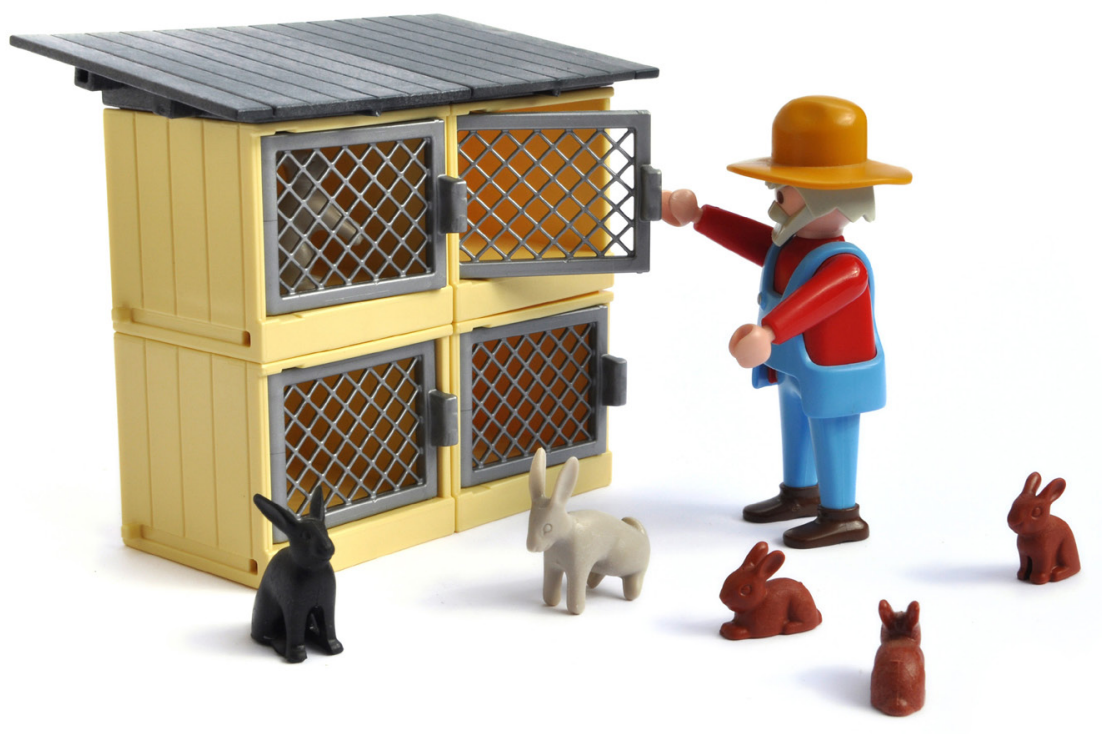


Meat rabbit production is estimated at more than 1 million tonnes per year worldwide, being China the largest producer. In Europe, meat rabbit production is mainly located in Mediterranean countries. Italy, Spain and France are the main producers and consumers (Press Release 01/57; FAO, 2001).

Intensive rabbit meat production emerged in Europe at the end of the 1960s, and the consolidation of industrialized rabbitries took place between 1980 and 1990 years (Lebas, 1997). Breeding programs in this species appeared later than those of other livestock species. The first breeding program was consolidated in France in the 1960s (Legault et al., 1996). In Spain, the rabbit breeding programs are being developed since the 1970s by two public institutions: the Universitat Politècnica de València (UPV, Valencia) and the Institut de Recerca i Tecnologia Agroalimentàries (IRTA, Catalunya) (Baselga, 2004).

The production system is based on a three-way crossbreeding scheme. In a first cross animals from two maternal lines selected for reproductive traits are mated in order to capture positive heterosis and complementarity effects on reproductive traits and eliminate within line inbreeding in the resulting crossbred does. The second cross consists in mating the crossbred does with males from a paternal line selected for growth rate or weight at a given age. The final aim of the cross is to capitalize on the complementarity between reproductive and growth traits to produce a large number of rabbits with fast growth and high feed efficiency (Baselga, 2004). The genetic improvement of rabbits for meat follows a similar pyramidal structure as in pig breeding: nucleus, multipliers and commercial farms (Baselga, 2004).

The intensification of the rabbit meat production, has led to specialization and increase of number of does in commercial farms. This has substantially transformed management systems, being the most important the change to a management in batches of the does. With this practice, a large number of females in the same physiological status are mated or inseminated the same day, which allows the synchronization of birth and weaning events among females within batches. The most economically profitable management system in terms of worked hour consists of inseminating all the does in a farm the same day (ITAVI, 2007). This is only possible with the artificial induction of ovulation and the use of artificial insemination (AI). Consequently, most of the commercial farms have changed the reproductive management from natural mating to AI and, in parallel, artificial insemination centres have appeared in order to commercially produce and distribute semen doses.

The widespread use of AI has accelerated the diffusion of the genetic progress achieved in paternal lines and improved the efficiency of the meat rabbit production.

With AI, the impact of reproductive performance of individual males is vital. Because of this, processes of dose production in AI centres aim at maximizing the probability of 
fertilization of the oocytes via management decisions on bucks, ejaculates and doses. As a consequence, fertility rates and litter size in commercial farms are usually high (ITAVI, 2008). However, efficient production of potentially fertile doses is suboptimal.

There are several aspects concerning the use of bucks in the centres that could be improved. The first one is buck replacement. The criteria for male culling are mainly: sickness, poor libido, and repeated occurrence of aspermia or seminal characteristics clearly indicative of infertility (azoospermia or asthenozoospermia). Improving output in AI centres would require a precise and early prediction of male sub-fertility. Regarding management practices, bucks' commonly follow an extensive ejaculate collection rhythm, consisting of getting one or two consecutive ejaculates per male each week. Ejaculate frequency can affect not only the semen production and quality but also the variation of these traits and some researchers have indicated that an extensive collection rhythm could not be the optimal in order to have a high and constant production of fertile doses (Desjardins et al., 1968; Bencheikh, 1995; Nizza et al., 2003).

Second, the process of ejaculate collection and dose preparation could be more efficient. Thus, there is a high pre-selection of ejaculates that are used for preparing the doses. The ejaculate rejection rate differ among AI centres but it can be as high as $40 \%$ (Brun et al., 2002a o b; Theau-Clement et al., 2003; Brun et al., 2006; García-Tomas et al., 2006c) which implies a great inefficiency of the process for dose production. The criterion to determine the suitability of the ejaculate for AI is based on a subjective combination of several quality traits of the ejaculate and the sperm cells. Some of these traits are associated with the presence of contaminants or residues in the ejaculate that preclude semen evaluation and utilization, such as the presence of urine, blood and some other residues. Other criteria are deficiencies in certain seminal characteristics such as sperm motility and a high percentage of dead spermatozoa which are expected to have negative effects on fertility. However, the ability of these seminal characteristics to predict reproductive performance is very low, as it will be discussed later. Thus, although they permit to discard the most infertile ejaculates, they do not allow distinguishing between fertile and sub-fertile ejaculates (Colenbrander et al., 2003). It is possible that a part of the rejected ejaculates could be useful or indeed even better for fertilization than some of the not rejected ones. Therefore an accurate, fast, simple and cheap assay for predicting reproductive performance would improve AI dose production efficiency.

In addition to the strong selection of the ejaculates, the type of doses commonly used and the storage conditions limit the production and the distribution area of the AI doses. For example, inseminations are performed at high sperm dosage in order to overcome the negative effects on fertility of semen with some bad characteristics (Saacke et al., 2000). In addition, only fresh or refrigerated semen is used in order to avoid the loss of potential fertility during storage. These practices reduce the output of AI centres, i.e. 9 
doses/ejaculate for a concentration of $40 \times 10^{6}$ spermatozoa/mL in the Caldes paternal line.

Finally, pooling ejaculates from several males for insemination (heterospermia) is a common practice in order to compensate for possible infertile ejaculates. The use of commercial heterospermic doses prevents individual identification, therefore reducing the efficiency of selection for improving male performance. To improve the output of the AI centers, it is necessary to know the importance and the roles of the traits involved in fertile dose production and conservation. Knowledge of the different sources of variation that are affecting each one of these traits would determine their possibilities and strategies of improvement 


\section{Objectives of the thesis}

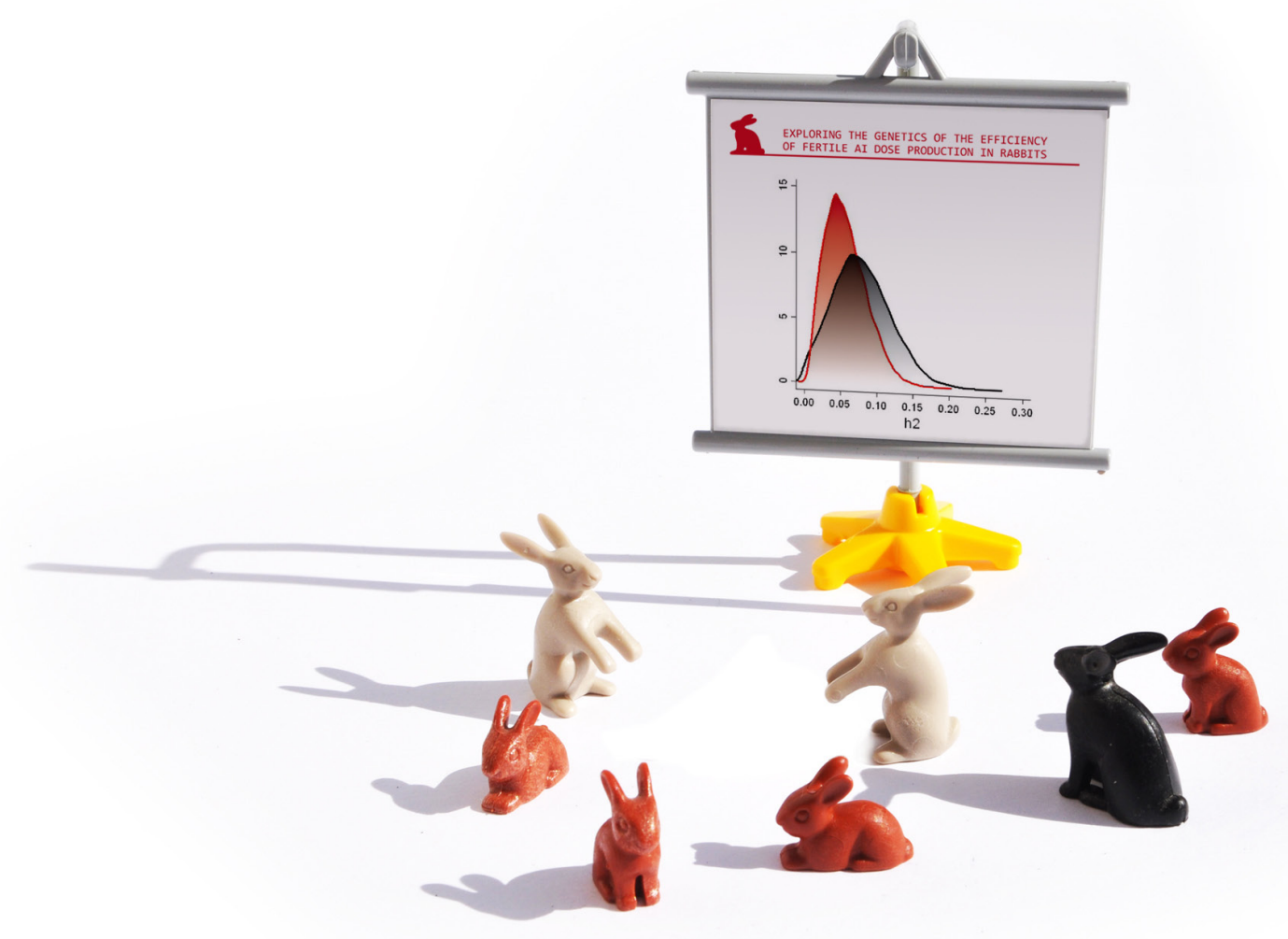


The aim of this thesis is to determine the relative importance of different sources of variation for some of the most important components of fertile AI dose production in order to explore the interest and limitations of different strategies for their genetic improvement. These components refer to seminal production and quality traits, being considered the male reproductive performance as the final expression of the effect of the seminal characteristics and the effect of the interaction among them and with the female. Thus, the specific objectives of the thesis were to determine in a paternal line of rabbits the following:

1. Genetic parameters of male libido and several characteristics of the ejaculate and the sperm (chapter one).

2. Genetic and phenotypic relationship between semen $\mathrm{pH}$-considered to be a global indicator of some seminal quality traits- and male fertility (chapter two).

3. Genetic parameters of male fertility and prolificacy (chapters three and four).

4. The existence of an interaction between the male genotype and the sperm concentration of the dose as well as between the AI conditions as a whole (conditions and duration of the storage period of the dose, genetic type of the female, environmental conditions of the farm) for male effect on fertility and prolificacy (chapter four).

5. The genetic relationship between male libido and several seminal quality and production traits with growth rate, which is the selection criterion of the line (chapter one).

6. The critical periods around the AI time in which the environmental temperature has a major effect on male and female components of fertility (chapter five).

Objectives 1 and 5 have been established to provide information regarding genetic improvement of seminal production and quality traits, and also to determine how these traits could have been affected by selection for growth rate. The feasibility of indirect selection through the use of an immediate, not expensive and easy to measure semen quality trait is attempted with objective 2 . Objectives 3 and 4 are focused on the definition of an effective model and strategy of selection for improving the male reproductive performance under given conditions of semen utilization by direct selection. Objectives 1 and 2 are also useful in obtaining information to define adequate criteria for ejaculate rejection and buck replacement in the artificial insemination centres. Finally, objective 6 was defined in order to better match the environmental temperature of the farm to the specific requirements of each sex in order to maximise fertility after AI 


$$
\begin{array}{r}
\text { Literature } \\
\text { review }
\end{array}
$$

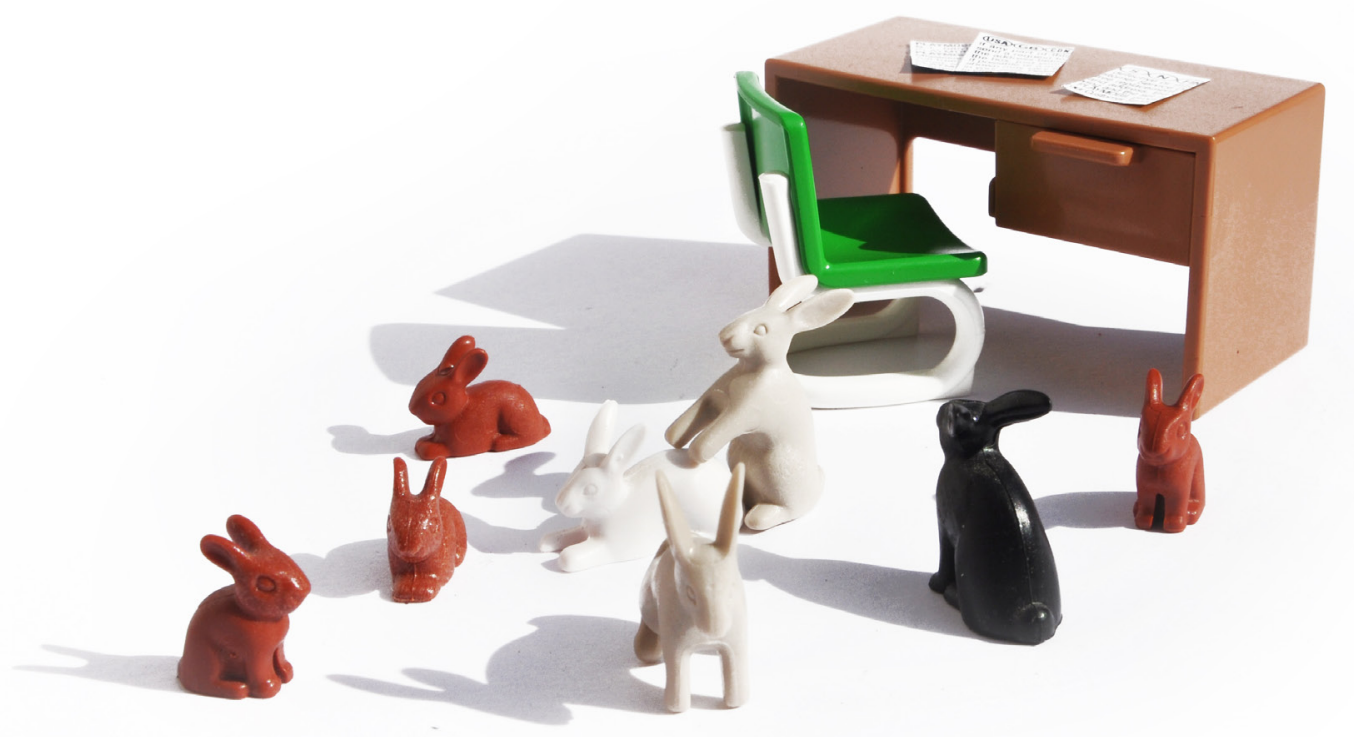




\subsection{Components of the production of fertile doses}

The production of fertile doses is determined by several components, which are affected by environmental and genetic factors. These are: male libido and characteristics of the ejaculate (which form part of the criterion for ejaculate rejection and impinge on the frequency of demanded ejaculations), volume and sperm concentration of the ejaculate (determining the amount of doses that can be obtained from an ejaculate) and the seminal quality of sperm (determining the minimum sperm dosage required to ensure fertilization).

\subsubsection{Male libido}

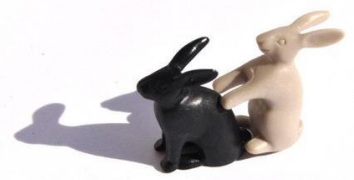

Male libido is his sexual drive, which determines the number of ejaculates that can be obtained and the time consumed for it.

A homemade artificial vagina containing water at approximately $50^{\mathrm{a}} \mathrm{C}$ is used for semen extraction. The artificial vagina is hand-held beneath a doe or a rabbit 'skin' and is placed inside the buck's cage to allow the male to mount it. As the buck began to mount, penetration of the penis into the artificial vagina is allowed and the ejaculate is collected in a tube (Morrell, 1995)(See Figure I.1). The rate of ejaculate collection with this method is high and therefore it is widely used in the AI centres (Theau-Clément et al., 2003; Brun et al., 2006; Garcia-Tomás et al., 2006c). However, AI centres tend to discard males with low libido as they require long collection time. Jointly with infertility, lack of libido is one of the most important causes for culling males in rabbit farms (Rosell and de la Fuente, 2009).

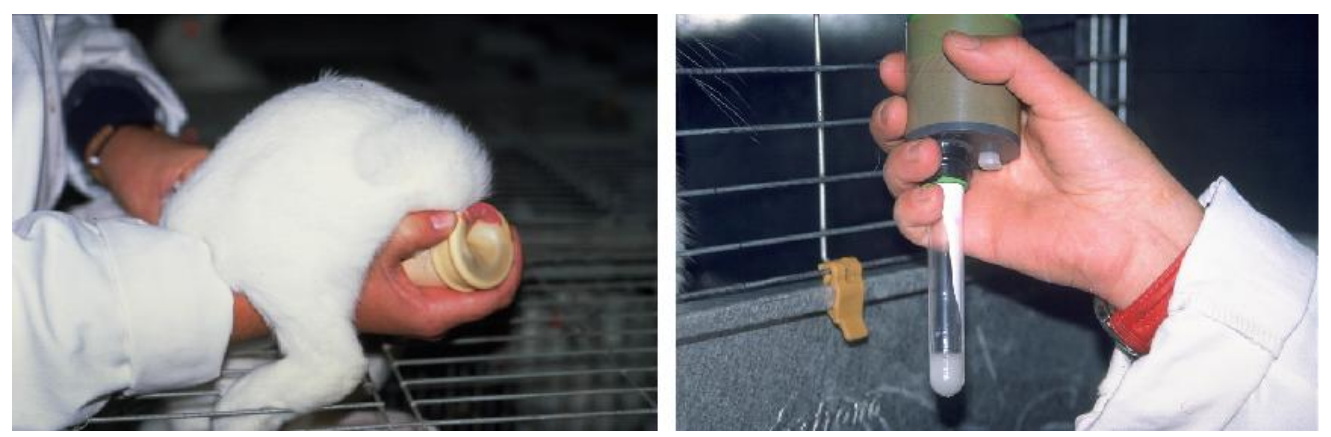

Figure I.1. Doe and artificial vagina disposition to perform ejaculate collection.

Male libido could be measured as the time between placing a doe in the buck's cage and ejaculation (Boiti et al., 2005; Brun et al., 2006) or as a categorical trait resulting from scoring the male libido (Panella et al., 1994; Khalil et al., 2007). The easiest and most common method to record male libido in an AI center is to indicate if the male successfully responded to the sexual stimulus. A more expensive, and hence not used alternative is to obtain an indirect 
measurement of male libido by measuring testosterone concentration in plasma as they are positively correlated (Flowers, 2008).

\subsubsection{Characteristics of the ejaculate}

\section{Appearance}

Ejaculates are visually assessed immediately after collection. Here, a proportion of suitable ejaculates is selected for further quality evaluation. Accepted ejaculates must have a greyopalescent colour. Ejaculates with blood, urine, calcium carbonate deposits or other minor residues are discarded. The presence of blood in ejaculates is not common. However, the frequency of ejaculates contaminated with urine, a spermicidal compound, is $5-13 \%$ (Brun et al., 2002a; Theau-Clément et al., 2003; Garcia-Tomás et al., 2006c). Gel plugs have to be removed from the ejaculate for dose preparation.

The presence of calcium carbonates deposits in the ejaculates is particularly high in the Caldes line (up to 26\%; Garcia-Tomás et al., 2006c). These deposits have also been encountered in the bladder but causes of their origin are still unknown. Ejaculates with calcium carbonates deposits should be discarded for AI because they prevent a proper evaluation of seminal quality in the lab and could have a detrimental effect on reproductive performance (Garcia-Tomás et al., 2006c).

\section{Ejaculate volume}

The volume of an ejaculate and the concentration of sperm are the main traits considered in sperm production, because they determine the number of spermatozoa that can be obtained from an ejaculate.

Ejaculate volume is usually directly measured in a graduate tube or in a graded pipette. Semen is composed by seminal plasma and spermatozoa. Therefore, ejaculate volume is determined by the amount of these two components.

Seminal plasma is a mixture of secretions produced in the epididymis and the accessory glands. Rabbit seminal plasma and specially its particulate fraction seem to play an important role protecting sperm from premature capacitation and acrosome reaction as well as modulating sperm kinetics, transit and immune response in the female tract (Castellini, 2008). Some plasma seminal proteins were related to fertility in bulls and stallions (Killian et al., 1993; Brandon et al., 1999; Macpherson et al., 2002) whereas no correlation was encountered 
between fertility and concentrations of other proteins, sugars and several free amino acids of the seminal plasma of Nelore bulls (Assumpção et al., 2005).

Ejaculates are diluted to prepare the AI dose considering only the spermatozoa concentration. However, the effect of dilution on the potential fertility of the doses is male specific because of individual variation in the composition of plasma and sperm quality (Killian et al., 1993). Haugan et al. (2007) found individual variation in the effect of dilution on probability of conception in bulls. In the case it was confirmed that higher ejaculate volume imply higher amount of seminal plasma (and smaller or constant number of sperm) then, the lower dilution factor required to prepare the dose could lead to a higher fertilizing potential. In addition, the concentration of seminal components with a favourable effect on fertility should remain constant or even increase with the increase of the ejaculate volume (or seminal plasma).

\section{Sperm concentration}

The sperm concentration is measured in millions of spermatozoids per mL of semen. The most common method for assessing sperm concentration is the haemocytometer (Thoma, Burker or Neubauer chamber; Boiti et al., 2005). It consists of a glass microscope slide with a rectangular chamber of certain known dimensions with a grid of perpendicular lines. The area bounded by the lines and the depth of the chamber are known. A diluted semen sample is placed in the chamber where it is possible to count the number of sperm cells in a specific volume and, thereby, obtain the sperm concentration (Figure I.2). Ensuring that the aliquot examined is adequate and representative of the ejaculate is mandatory (ESHRE-SIGA, 2002). The haemocytometer is the cheapest method but it is time consuming and tedious since it requires a person counting for about 10-15 minutes per sample.
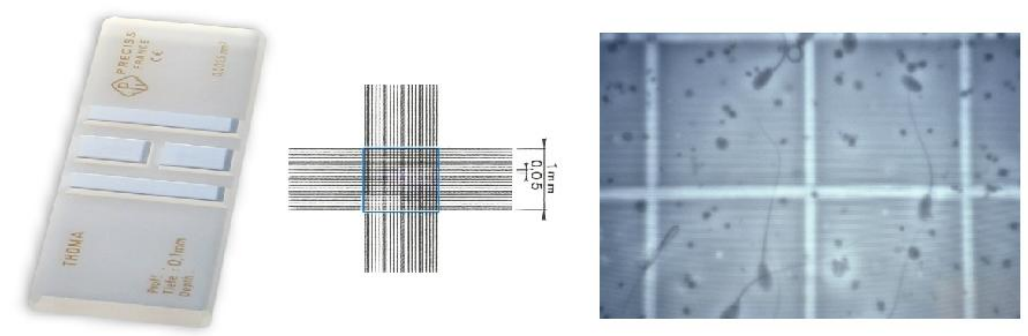

Figure I.2. Counting chamber Thoma for determining sperm concentration.

When sperm concentration needs to be determined in a large number of samples, other quickest but more expensive methods could be used. Theau-Clément and Falières (2005) found a high correlation between the Nucleocounter SP100 (Chemometec A/S, Allerødn 
Denmark) and the haemocytometer. The Nucleocounter SP100 determines the sperm concentration of the sample based on the fluorescence emitted by the Propidium Iodide previously fixed in the DNA of the nucleus of the spermatozoids (Figure I.3).
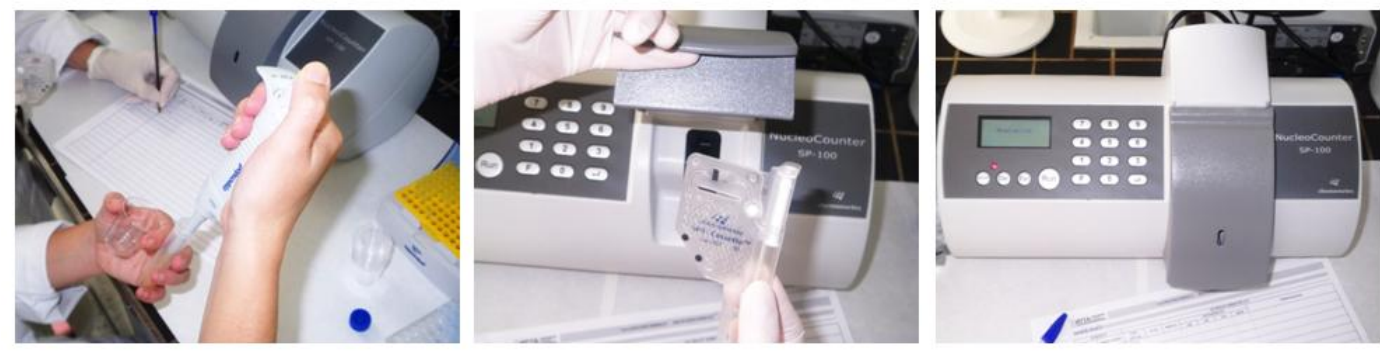

Figure I.3. Nucleocounter SP-100 (Chemometec, Allerod, Denmark) for determining sperm concentration.

Rabbit sperm contains a high amount of particles that are secreted by different accessory glands and seem to play an important role in sperm capacitation and acrosome reaction of the sperm (Castellini, 2008). However, high presence of these particles in rabbit semen makes difficult the determination of sperm concentration by using techniques that are commonly implemented in other species. For example, the CASA technique (Computer-Assisted Semen Analyzer), conceived for the evaluation of sperm kinetic traits, could be used for determining sperm concentration. However, it seems that it does not provide an accurate measurement of spermatozoa concentration in rabbits. Taking into account the particle/spermatozoa ratio, Castellini et al. (2007) developed a spectrophotometer assay for determining sperm concentration in rabbit.

An indirect effect of the number of sperm used per insemination on fertility exists because the effect on reproductive performance of some deficiencies in seminal quality traits can be masked when high sperm dosage is used for insemination. Lowering sperm dosage in AI doses prevents compensation of deficiencies and decreases fertility rate and litter size (Saacke et al., 2000).

In rabbits, several works have studied the relationship between sperm concentration of the AI doses and fertility in order to establish which was the minimum dosage required to avoid compromising fertility rates (Farrell et al., 1993; Alvariño et al., 1996; Viudes-de-Castro and Vicente, 1997). This figure is highly variable among works because it largely depends on the conditions in which $\mathrm{AI}$ is performed (i.e. type of extender used, time and conditions of storage and semen quality; Castellini et al., 1999).

As commercial AI in rabbits is performed with heterospermic doses, sperm concentration in the AI centres is only measured once several ejaculates suitable for AI have been pooled. The most common method used for determining the sperm concentration of the pool is the 
haemocytometer. However, some AI centres record individual sperm concentration in a subjective score in order to discard azoospermic males or males with poor sperm concentration.

\section{$\mathrm{pH}$ of the ejaculate}

In general, the higher is the concentration and motility of spermatozoids in the ejaculates, the lower is the pH due to a greater production of lactic acid (Hulet and Ercanbrack, 1962; Coffey, 1988; Bencheikh, 1995; Brun et al., 2002b; Garcia-Tomás et al., 2006b). Thus, as pH is related to some seminal traits, several studies in rabbit have found negative correlations between $\mathrm{pH}$ of ejaculate and fertility (Coffey, 1988; Brun et al., 2002b) or litter size (More O'Ferrall and Meacham, 1968). Therefore, $\mathrm{pH}$ is an indicator of semen quality and it could offer to AI centres an easy way to select ejaculates and males in order to improve fertility.

Semen $\mathrm{pH}$ should be measured immediately after collection in order to avoid variation due to metabolic changes of the sample. It can be measured either using a glass electrode or a pH indicator.

\subsubsection{Sperm quality}

There are several attributes spermatozoa must have in order to be fertile. These attributes are related to its capability to accomplish the different biological processes required to reach the oocyte, fertilize and initiate the embryonic development (for details see Amann, 1989). In addition to those spermatozoa characteristics other factors such as timing of the occurrence of the processes are important to determine the spermatozoa fertilizing potential.

Some of the standard and newly developed semen quality tests used to measure spermatozoa fertilising attributes are: tests that analyse the cell characteristics of the spermatozoa, spermoatozoa functional tests and tests analysing possible molecular indicators of fertility.

\section{Cell characteristics of spermatozoa}

\section{Sperm motility}

Spermatozoa require good motility in order to cross the female genital tract, reach the oocytes and perform a successful fertilization. Moreover, sperm motility is a good indicator of the status and functionality of the sperm membrane (Gadea, 2005). As it is simple, quick, and inexpensive to measure, sperm motility is one of the most widely used tests in AI centres. 
Sperm motility is usually evaluated by examining several random fields using a microscope with a phase-contrast optic. There are two types of subjective evaluations of this trait: the mass motility and the individual motility score. The first one is a subjective evaluation of the oscillatory movement of all spermatozoids as a whole and it is measured in undiluted semen. The second method refers to the movement of individual spermatozoa and it is given as the percentage of motile spermatozoids showing progressive movement and it is measured in diluted semen (Roca et al., 2000).

The Computer-Assisted Semen Analyzer (CASA) systems can provide an objective evaluation of the sperm motility pattern (Verstegen et al., 2002). These systems are able to record several kinetic parameters such as the percentage of motile sperms, curvilinear velocity (VCL), straight line velocity (VSL), average path, amplitude of lateral head displacement about its average path (ALH) and beat cross frequency (BCF) of the spermatozoids, etc (Figure I.4). Some of these parameters are related to the hyperactive motility pattern of the sperm needed to penetrate the zona pellucida of the oocyte (Cancel et al., 2000). In order to obtain reliable estimations of the kinetic parameters, a specific set-up must be previously defined for rabbit semen to avoid, for example, counting particles instead of sperm heads, a representative number of fields should be analyzed and the environmental conditions should be stable along all the analyzed samples (Boiti et al., 2005).

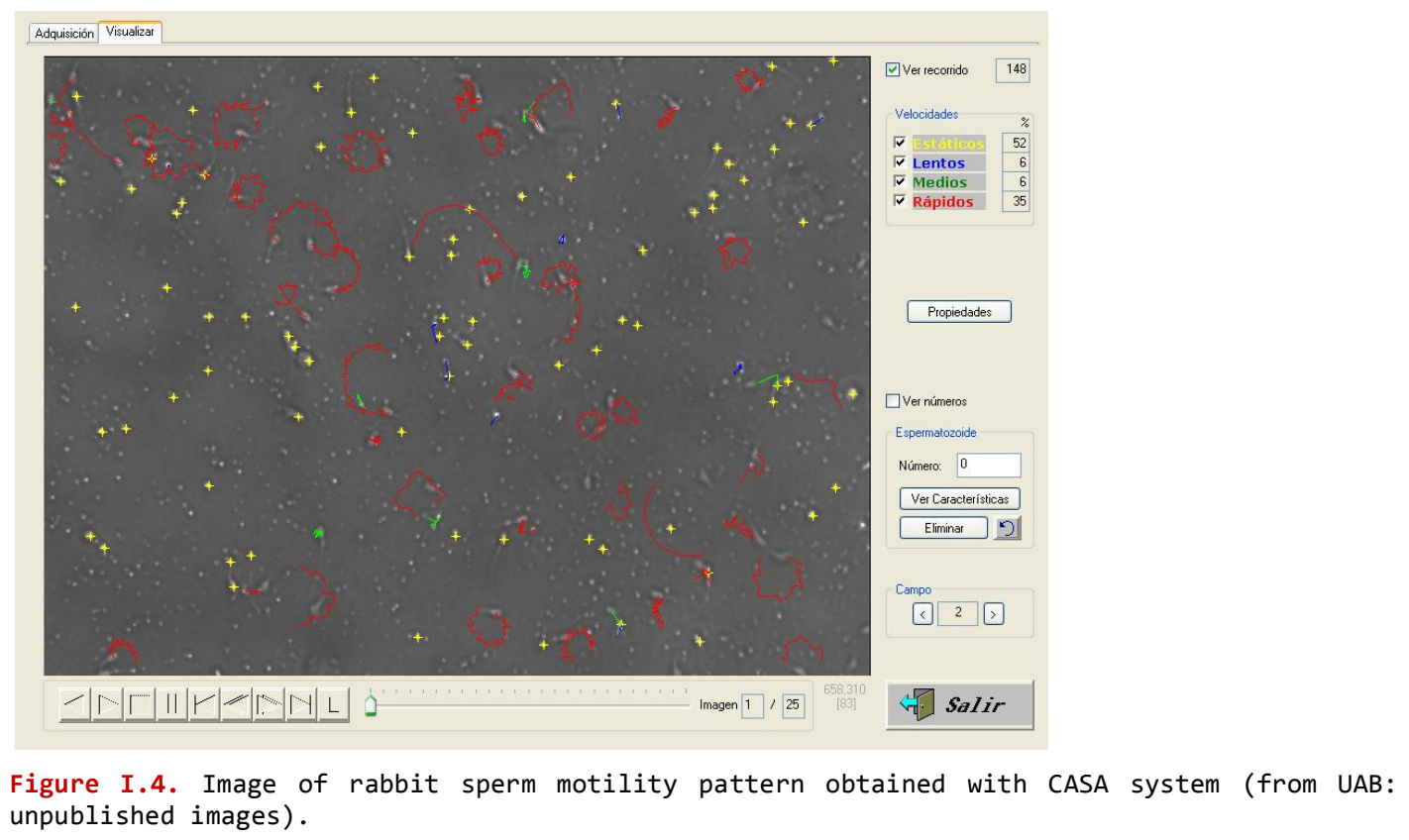

Sperm motility is a good indicator of poor fertility, however, high values do not guarantee good fertility, i.e. in boars the correlation between traits is moderate (Flowers, 1997; cited by: Braundmeier and Miller, 2001). In rabbits, variable estimates of phenotypic correlations 
between sperm motility and fertility have been obtained, probably due to the subjective manner in which these motility traits are evaluated, the high pre-selection of the ejaculates used to obtain fertility data and the different evaluation criteria used. Brun et al. (2002b) found that mass motility score was the most influential trait on kindling rate among several quantitative and qualitative seminal traits analyzed. Garcia-Tomás et al. (2006a) found no clear relationship between fertility and individual motility evaluated according to a subjective scale. However both studies rejected the worst ejaculates, based, among other variables, in sperm motility, and therefore it contributed to diminish the amount of variation for this trait and possibly reducing its correlation with fertility.

Measurements obtained with CASA systems seemed to be more correlated with fertility than subjective evaluations of motility (Farrell et al., 1998). Different correlations between sperm motility and fertility have been obtained in rabbits. For example, a correlation of 0.39 was obtained between number of progressive motile sperm and percentage of oocytes fertilized and a higher correlation (0.53) was obtained when kinetic traits obtained with C.A.S.A. and ovarian characteristics were included in the model (Farrell et al., 1993). However, velocity measurements $(\mu \mathrm{m} / \mathrm{s})$ did not correlate more with fertility than the subjective evaluations of the percentage of motile sperm (Hagen et al., 2002). Moderate correlations were encountered between kindling rate and percentage of motile spermatozoa or spermatozoa linearity index (Lavara et al., 2005).

\section{Sperm Viability}

Sperm viability consists of evaluating the proportion of vital ('live') spermatozoa in the sample. There exist different protocols of staining live/dead sperm (by optic or fluorescence microscopy). The principle is that spermatozoa with intact membrane do not allow the penetration of the stain whereas damaged cells take the colour of the stain (Bamba, 1988; Boiti et al., 2005). The most common evaluation of sperm vitality is performed staining the sample with eosin-nigrosin and examining at least 200 spermatozoa in several fields with a microscope (Bamba, 1988) (see Figure I.5).

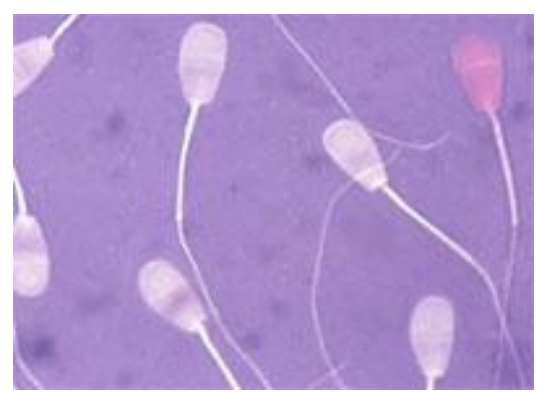

Figure I.5. Eosin-nigrosin staining for the determination of rabbit sperm viability. Normal live sperm exclude the eosin stain and appear white in color, whereas "dead" sperm (i.e. those with loss of membrane integrity) take up eosin and appear pinkish in color (from: IRTA unpublished images). 
Garcia-Tomás et al. (2006a) found no relation between sperm viability (assessed through Eosin-Nigrosin staining) and fertility in rabbits. Using a fluorescence method in bulls, the correlation between the total number of viable spermatozoa in the insemination dose and field fertility was low (Alm et al., 2001). In bulls, sperm viability assessed through flow cytometry was also correlated with 56-day non-return rate (Christensen et al., 2005).

\section{Sperm morphology}

Morphological deviations from the normal (more frequent) rabbit spermatozoa shape are considered morphological anomalies (i.e. large, small or amorphous head, asymmetrical tail insertion, thin mid piece, short, double or coiled tail, etc...) (see Figure I.6).

Sperm anomalies are usually registered according to the region of the spermatozoa where they are located because the type of sperm defect and/or the sperm region where it is located could indicate in which moment of the process the sperm have been damaged. Accordingly, two types of sperm defects can be distinguished: the primary sperm anomalies, originated in the testis during the spermatogenesis phase; and the secondary sperm anomalies, originated in the epididymus during the maturation and storage phase of the sperm. Evaluation of morphological anomalies is performed under a microscope, using specific staining (i.e. EosinNigrosin staining method; Bamba, 1988). After examining at least 200 spermatozoa of several fields of the microscope, anomalies in each region are expressed as percentage of spermatozoa with defects for that region.
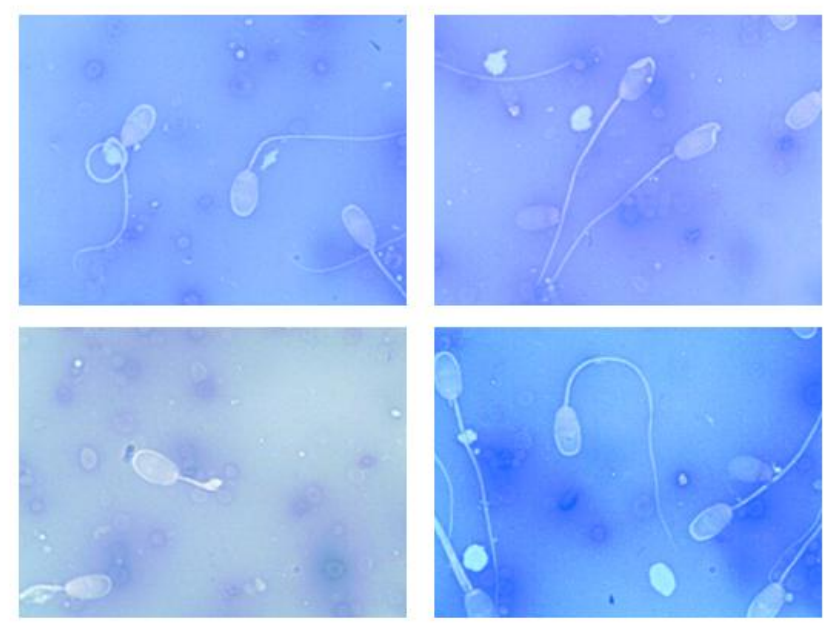

Figure I.6. Different rabbit sperm abnormalities (from: IRTA unpublished images)

There is no consensus for classifying sperm according to its morphology making difficult the comparison of results across studies. Thus, in rabbits, Kuzminsky et al. (1996) classified spermatozoids into 4 categories: normal spermatozoids, spermatozoids with head and tail 
anomalies and broken spermatozoids. Similarly, Pérez-Sanchez et al. (1997) classified them into 5 categories: normal spermatozoids, spermatozoids with head, neck and mid-piece and tail anomalies and spermatozoids with presence of multiple anomalies (sperm with more than 1 defect).

Cytoplasmic droplets can be present in the ejaculated spermatozoa being located somewhere from the base of the head to the neck mid piece region. There is no consensus in how to classify them. Some authors consider the presence of cytoplasmic droplets as sperm defects whereas other authors postulate that their presence is an indicator of sperm immaturity (Barth and Oko 1989).

When assessing sperm morphology it is of great importance to have high quality preparations because small differences in laboratory techniques could influence the appearance of the spermatozoa (ESHRE-SIGA, 2002). Hence, the highly subjective visual assessment of sperm morphology may explain the low repeatability of sperm defect traits in humans (Zaini et al., 1985).

In an attempt to reduce the subjectivity of the assessment of sperm head morphology, Computer Automated Sperm Morphometry Analysis (ASMA) systems have been commercially developed for several livestock species since the 1990s (Gravance et al., 1996). However, as it occurs with CASA systems, the specific set-up for each species must be previously well defined in order to obtain reliable measurements (in rabbits: Gravance and Davis, 1995). Unfortunately, ASMA systems do not allow studying tail defects which are very common in some species.

The presence of morphologically abnormal sperm is an important indicator of potential semen fertility. For example, in humans, it has the highest correlation with fertility among all measured sperm characteristics (Barth and Oko, 1989; Ombelet et al., 1995; Keel and Schaule, 2000; Mortimer and Menkveld, 2001). In several livestock species, negative correlations between presence of sperm abnormalities and fertility have been reported (in bulls: Correa et al., 1997; Rodríguez-Martínez, 2003; in boars: Gadea, 2005). However, it is difficult to compare results obtained among studies because of the subjective manner in which these sperm abnormalities are evaluated and the different classification systems used to assign sperm defects into different categories (Braundmeier and Miller, 2001). In rabbits, a negative correlation between the percentage of abnormal sperm cells and kindling rate was observed (0.32, Lavara et al., 2005), although it was not significant when it was included in a multiple regression model. Nevertheless, Garcia-Tomás et al. (2006a) reported a poor fertility and prolificacy prediction of this sperm trait using multiple regression. 


\section{Status of the sperm acrosome}

In order to develop fertilizing capacity, once spermatozoa reach the female genital tract must be activated in a process called capacitation. This process enables spermatozoa to bind the zona pellucida of the oocyte. Then spermatozoa have to initiate acrosome reaction which is an exocytotic event required for penetrating the oocyte and achieve fertilization.

The proportion of acrosome reacted spermatozoa or abnormal acrosome spermatozoa in an untreated semen sample is indicative of its fertilizing ability because these spermatozoids are not able to fertilize and their longevity is short. The sperm acrosome status could be evaluated either by morphological techniques (using electronic or optic microscopes; Casey et al., 1993; Zeginiadou et al., 2000) or by membrane molecular markers (fluorescent marked lectines and specific antibodies; Cross et al., 1986; Mortimer et al., 1987; Figure I.7). In rabbits, a negative and moderate correlation was found between fertility and percentage of abnormal acrosomes (Courtens et al., 1994). Likewise, fertile stallions presented fewer percentage of acrosome reacted sperm in their ejaculates (Pesch et al., 2006).

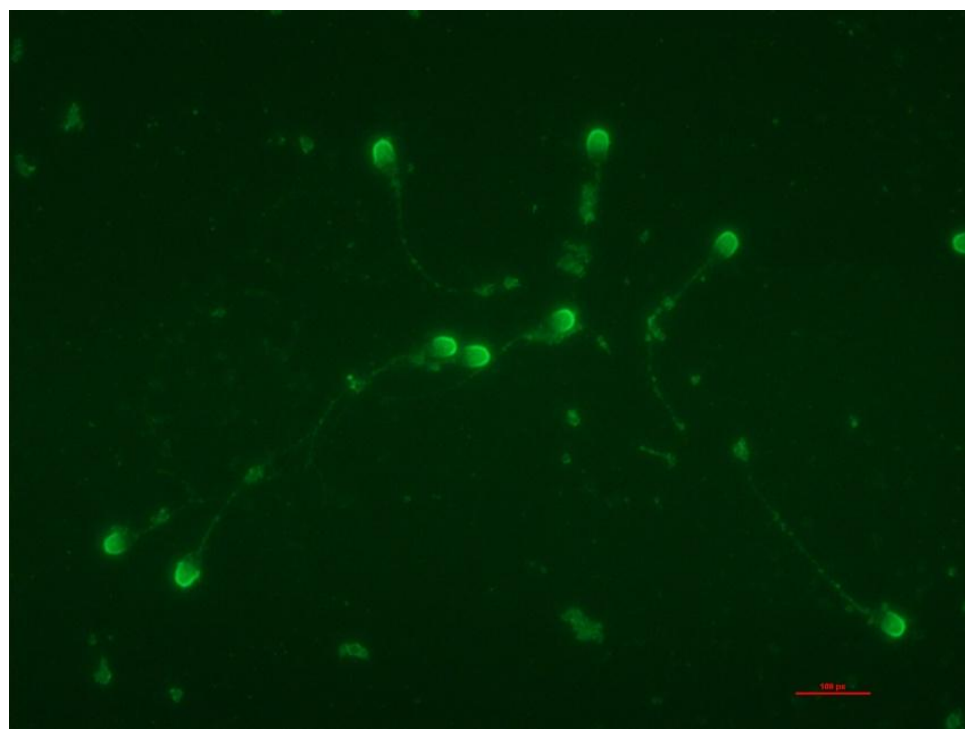

Figure I.7. Acrosome status of rabbit spermatozoa using FITC-Pisum sativum lectin (FITCPSA) (from: UAB unpublished images).

\section{Sperm DNA fragmentation}

Even if fertilization is successful, posterior embryo development could be disrupted if sperm chromatin structure is altered. Altered chromatin leads to problems of decondensation, necessary for male pronucleus formation during fertilization (Perreault et al. 1987, cited by: Colenbrander et al., 2003). Moreover, high condensation of sperm chromatin is a mechanism of protection from environmental stress and mutagenesis (Ward and Coffey 1991, cited by: Colenbrander et al., 2003). Deficiencies in sperm chromatin structure is considered to be a 
trait that cannot be compensated by increasing the amount of sperm in the dose since damaged sperm is able to reach the oocyte and can initiate fertilization but cannot complete activate embryonic development (Saacke et al., 1994).

There are four types of tests to assess sperm DNA fragmentation: the Comet, Tunel, Sperm Chromatin Structure Assay (SCSA, Figure I.8) and the Acridine Orange test (Evenson and Wixon, 2006).

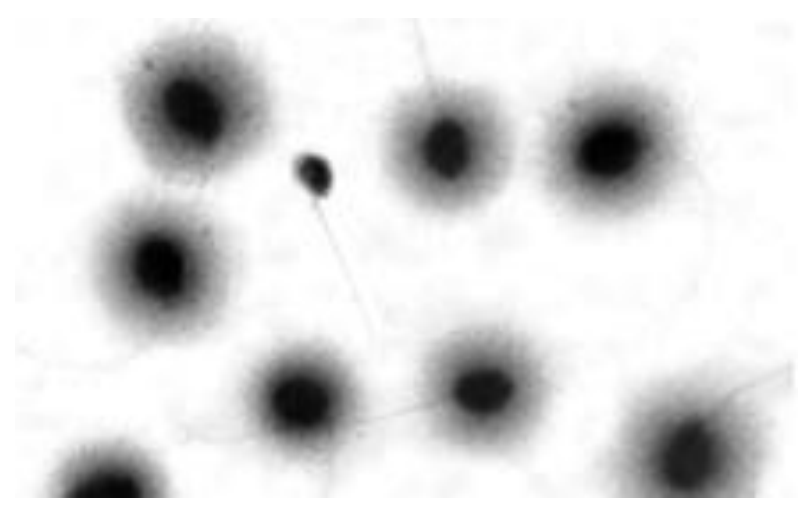

Figure I.8. From Enciso et al. 2006. DNA fragmentation of men sperm determined with the sperm chromatin dispersion (SCD) test using the Halosperm ${ }^{\circledR}$ kit. Sample only showing a sperm nucleus with fragmented DNA in the microscopic field, evidenced by the absence of halo.

In rabbits, sperm chromatin alterations have been found to be correlated with the presence of sperm head defects (Beletti and Mello, 2004). However, the relation of sperm DNA fragmentation with other conventional semen quality tests has not been clearly established in other species, (reviewed by: Ardón et al., 2008). DNA fragmentation have been found to be negatively correlated with fertility in different species (Ballachey et al., 1988; Evenson et al., 1994; Sailer et al., 1995; García-Macías et al., 2007).

\section{Functional sperm tests}

\section{Hypoosmotic swelling test (HOS)}

The hypoosmotic swelling test is an alternative to the sperm vitality staining test. The difference between the two is that HOS not only tests for membrane integrity but also whether membrane is osmotically active or not (Neild et al., 1999; Colenbrander et al., 2003).

Researchers have variable estimates of the correlation between HOS and fertility, and it seems HOS may be more appropriate for predicting the fertilizing capacity of thawed semen than of fresh semen (in stallion: Colenbrander et al., 2003). 


\section{In vitro induction of sperm acrosome reaction}

The acrosome reaction is normally induced by the zona pellucida when the spermatozoon contacts the oocyte inside the female tract. In order to test the acrosomal functionality in the lab, an alternative approach is to use inducing agents to determine whether the sperm is able to undergo capacitation and acrosome reaction (Whitfield and Parkinson, 1995). This method seems to be more informative with regards to the fertilizing capacity of fresh semen than the morphological evaluation of the sperm acrosome status but its relation with fertility is not clear (in stallion: Colenbrander et al., 2003) although there is some evidence of it in bovine (Whitfield and Parkinson, 1995).

\subsubsection{Tests analyzing possible molecular indicators of fertility}

Several seminal tests have been recently developed to assess molecular markers of semen fertility potential.

Nitric Oxid and Nitric Oxid synthase are enzymes that modulate both capacitation and acrosome reaction in sperm (Revelli et al., 2001). In bulls, these enzymes also affect sperm motility (Meiser et al., 2000) and ability to bind the zona pellucida in bulls (Francavilla et al., 2000). There are several seminal plasma proteins as well as spermatozoa proteins that have been related with male fertility in humans and in cattle such as Osteopontin, Prostaglandin D synthase and heparin-binding proteins (Braundmeier and Miller, 2001). Finally, the Heat shock proteins seem to be related to reduced seminal quality of individuals exposed to hot environmental temperatures (reviewed by: Braundmeier and Miller, 2001).

\subsubsection{Predicting fertilizing potential of ejaculates through seminal traits}

Once the main characteristics of ejaculates and sperm have been evaluated at AI centres, the technician selects the suitable ejaculates for AI.

This selection is based on the fertilizing potential of ejaculates predicted by their seminal characteristics. Amann and Hammerstedt (2002) described the "fertilizing potential of a male (or a semen sample) as the probability (or capability) of their spermatozoa to successfully participate in fertilization. Despite of its importance, accurate predictions are not currently obtained. Criteria for ejaculate rejection differ widely among centers. These are mainly based 
on ejaculate characteristics and a few subjective sperm quality traits, such as motility score and percentage of dead sperm. Such criteria allow distinguishing potentially infertile ejaculates but cannot guarantee that acceptable fertility rates will be achieved with the selected samples (Colenbrander et al., 2003). Even using new methodology to evaluate functional sperm capacity, the ability to predict fertility is still poor (reviewed by: Braundmeier and Miller, 2001; Amann and Hammerstedt, 2002; Braundmeier et al., 2004). The most critical features for obtaining a good prediction of fertility are:

The variables and laboratorial tests used as descriptors of semen quality could not be the best markers of fertility. Since a spermatozoon has to accomplish multiple requirements to be able to undergo the different processes leading to fertilization and activation of successful embryonic development in the correct timing, several authors have suggested that using a combination of multiple seminal traits (morphological and functional) would be better for predicting fertility than a single characteristic (Braundmeier and Miller, 2001; Colenbrander et al., 2003; Gadea et al., 2004). However, deciding which set of seminal characteristics to measure is unclear. The main reasons are: 1) Laboratorial tests obtain average measures of variables in the whole sperm sample. However, the characteristics of successful spermatozoa (those that fertilize the oocytes) could not be the same as the average ones (Braundmeier and Miller, 2001). 2) The evaluation of sperm characteristics in ejaculates is usually performed well in advance of insemination time and some of those characteristics change during this time. 3) Most of the sperm attributes are measured in a subjective and not precise manner at the AI centres. 4) The selection of the variables used as semen quality markers has been performed from results of experiments in which the fertilizing potential of seminal samples is evaluated under commercial conditions (i.e. high sperm dosage and pre-selection of the ejaculates by seminal characteristics). These conditions maximize the probability of fertility but are not optimal for detecting individual variation in fertility (Amann and Hammerstedt, 2002; Gadea et al., 2004). For example, increasing sperm dosage is a common practice to compensate for poor sperm characteristics because the negative effect on fertility of some seminal traits (i.e. motility and morphology deficiencies; Saacke et al., 2000) can be reduced if high number of sperm is used for AI. This practice reduces the amount of individual variation in fertility. Moreover, the strong pre-selection of the ejaculates and males for seminal quality traits, reduces the amount of observed variation in those traits making difficult to know its relationship with fertility (DeJarnette et al., 2004; Gadea, 2005).

The statistical methods used for variable selection and prediction could be suboptimal. Most studies assume a linear relationship between fertility and semen 
quality traits and give information about the goodness of fit of the model and estimates of the effects of the different semen quality traits (Brun et al., 2002b; Gadea et al., 2004; Garcia-Tomás et al., 2006a). However, it is not common practice standardizing the independent variables, and predictability power in a new set of data is not shown. Obtaining a model with a good fitting to the data does not imply that the same model is going to perform well in a new data set. This is an important point often ignored in many studies that have tried to infer fertility trough seminal quality variables. Moreover, the selection of variables used in prediction and the importance of each of them is based, in most of the studies, on the magnitude of the partial coefficients of a multiple regression of fertility on seminal traits frequently without taking into account the differences in variation for each of them or the problems of colinearity due to the high correlation between some seminal traits included in the model.

More flexible models which consider any kind of relationship between independent and dependent variables, like non-parametric procedures, could be tested. Tusell et al. (2009b) presented some preliminary results of fertility prediction based on seminal quality parameters using the Neural Network algorithm (Bishop, 1995), and Piles et al. (2010) evaluated the performance of the modified Ant Colony algorithm for variable selection proposed by Shen et al. (2005) and the Neural Network algorithm, by comparing the ability of these algorithms to predict male fertility in an independent set of data against the classical multiple regression model.

Finally, the ability for predicting fertility after AI with doses obtained from a particular ejaculate is limited because of the existence of important sources of variation not related to males, such as variation in females, embryos, environment (Koops et al., 1995; Foote, 2003) and interactions among them and with semen.

\subsubsection{Male reproductive performance}

Male reproductive performance and the semen production are the two components involved in the production of the fertile doses. The first one is the final expression of the effects of semen quality traits and the interaction among them and with the female. Consequently, it is a very complex trait which is affected by several genetic and environmental factors and their interaction (Koops et al., 1995; Foote, 2003).

The importance of reproductive performance in the whole economic animal production has widely been recognized (Armero and Blasco, 1992). In prolific species like rabbits, the number of litter per female and year and the number of kits born per litter are important components 
included in the equation for evaluating the productivity per cage and year in commercial farms (Armero and Blasco, 1992, Gómez, 2006). In beef, reproduction efficiency was estimated to be 5 times economically as important as other production traits such as growth (Trenkle and Willham, 1977).

In general, good fertility and prolificacy results after $\mathrm{AI}$ are obtained in rabbit farms ( $80.5 \%$ of conception rate and 10.34 number of total kits born per litter were obtained on average in French rabbit farms; ITAVI, 2008) being similar than those achieved after natural mating (Morrell, 1995) (for a brief description of the whole process in rabbits see Figure I.9). This is partly because dose preparation is done under commercial conditions and partly because of induction of receptivity and superovulation in females. However, reduced reproductive performances have been reported in some experimental studies in which AI conditions were more restrictive than the commercial ones. For example, when using homospermic doses of pre-selected ejaculates and not inducing female receptivity Brun et al. (2002b) obtained a reduced kindling rate of $(57,4 \%)$, although acceptable values of litter sizes were obtained (10.5). A pregnancy rate of $23 \%$ and low number of implantated embryos (4.9) were obtained when only 1 million sperm was used to inseminate receptive multiparous does (Viudes-deCastro and Vicente, 1997).
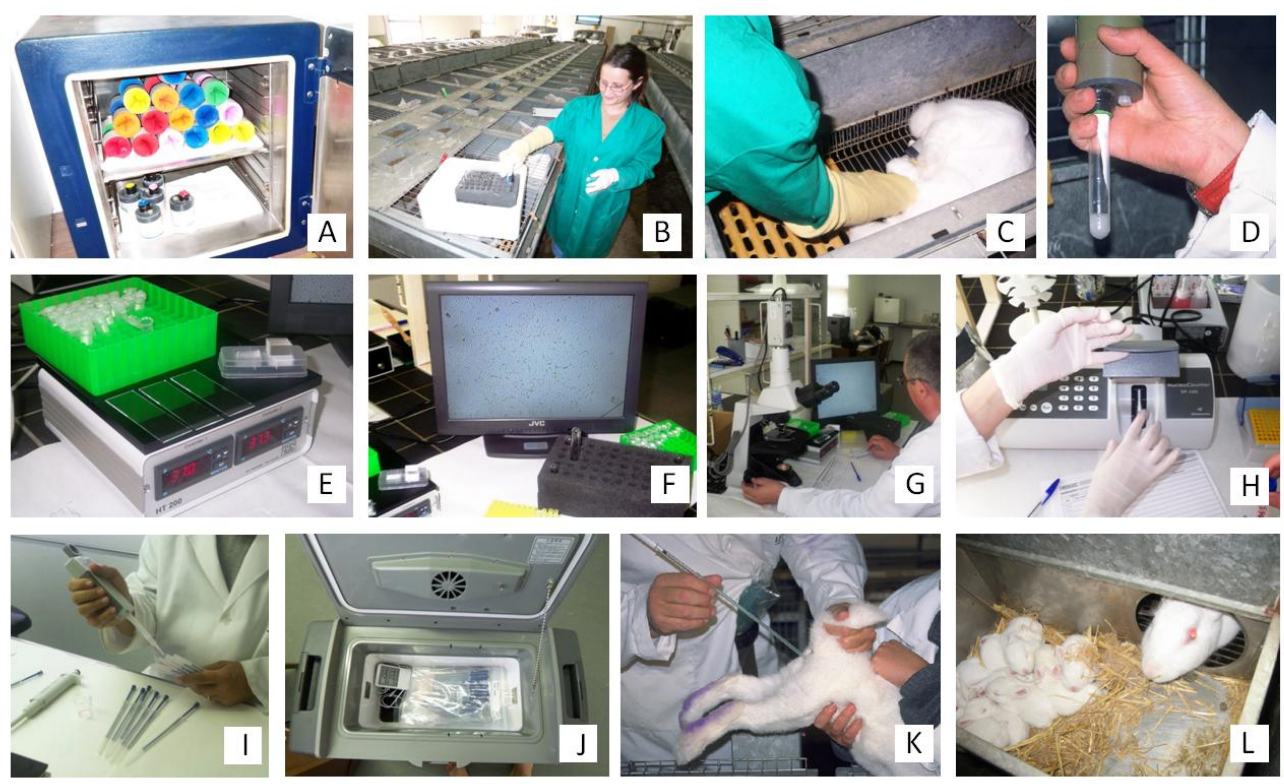

Figure I.9.From ejaculate collection to parity: A) artificial vaginas in the oven, B) bucks room, C) buck mounting the artificial vagina, D) ejaculate in the collection tube, E) semen samples in the hot plate, $F$ and $G$ ) microscopical evaluation of the seminal samples, $H$ ) Determination of the sperm concentration of the pool of semen suitable for AI, I) Filling up the heterospermic doses, J) AI doses in the temperature controlled semen storage box, K) doe insemination in the farm, L) litter born after AI. 
There are several difficulties in defining an appropriate trait to cover all aspects of fertility. Moreover, in some livestock species it is not easy to establish an efficient recording system and/or to evaluate this complex trait under adequate conditions (Thaller, 1998). Thaller (1998) classified the types of fertility measures used in animal breeding in three different groups: indirect fertility measured trough the use of physiological traits (like hormonal levels, reproductive quality traits in females and semen quality traits), traits related to various time periods and 'success traits'.

The time periods measurements of fertility are commonly used in cattle and sheep. The use of these measurements has the objective to maximize the benefit per unit of time because of the reduction of unproductive periods of the female. They are continuous traits that can be assumed to follow a normal distribution. There are several ways of measuring such interval: parturition intervals, intervals from parturition to first or last insemination, intervals between first and last insemination and intervals between consecutive inseminations, etc (Thaller, 1998). However, there is no consensus about which measurement is best. For example, calving interval, one of the most widely used measures, requires time to get information and there may be biases due to lack of data on primiparous and first calving infertile females. In general, time interval measurements present a high incidence of censored data such as missing records from inseminated females that have been culled before parturition (González-Recio, 2006). Moreover, variation in management practices must be accounted for.

The 'success traits' measure the result of a mating or an AI. They can be either expressed as a proportion of success events or as a single event.

The conception rate (or the percentage of gestations with respect to the total of matings or inseminations) is a global measurement of the reproductive performance of the individual during a certain period of its productive life (or its whole productive life). It is a continuous trait. However, as it is a summary measure of several events, it does not allow correcting for environmental factors related to each one of the events (i.e. year-season, age, female effects, etc). Another disadvantage is that enough data are needed per individual in order to obtain a accurate measurement, which can be lengthy especially among species with large gestation length.

Fertility defined as success or failure to conception is a binary trait, and therefore requires more complex analyses (Gianola, 1982). Depending on the species, the success could be determined either at parity or after some interval of time after insemination, like in the non-return-rates in cattle. These fertility measures can be 
corrected for the environmental factors specific to each mating. Moreover, data are obtained earlier than in the case of conception rate.

Prolificacy or litter size could be considered as another fertility measure in prolific species like rabbits or pigs. Swierstra and Dyck (1976) obtained a correlation of 0.80 between conception rate and average litter size in boars. Litter size in rabbits is commonly measured at three different moments: at birth, at weaning or at slaughter. Each type of prolificacy measure provides different information: the first one is more focused on the fecundancy and the ability to develop a successful gestation until birth (being the most adequate for male evaluation), the second one is, in addition, an indicator of the milk yield production and the maternal ability, and the third is the most economically interesting because it determines how many kits will be slaughtered per doe, but it presents a little longer generation interval (Santacreu, 2002). Furthermore, prolificacy is easily measured, and follows an approximate Gaussian distribution.

\subsection{Factors of variation of the production of fertile doses}

The efficiency of dose production at AI centres depends on factors such as buck's stage of sexual development, genetic background, and environmental (e.g. management) factors. Such efficiency could be improved through several complementary strategies. The first one is the use of bucks with good seminal characteristics and elevated fertility because of their genetic background. This can be achieved by using bucks from certain breeds or crossbred populations or by genetically improving specialised lines. However, finding this type of breeds or crossbreds could be difficult especially if good growth and feed efficiency performance is also required. Therefore, genetic selection could be an interesting alternative. Other strategies for improving male reproductive performance are using more appropriate management practices (bio-stimulation, optimum collection rhythm, etc) and a better control of environmental conditions (temperature, humidity, photoperiod, health status, etc).

\subsubsection{Environmental factors}

The environmental factors include both management practices and environmental conditions. In this section, main results relating management and environment to production of potentially fertile doses are described. 


\section{Management practices}

Some of the most important management practices are those related to ejaculate collection. One of them is offsetting an optimal ejaculate collection frequency. In rabbits the most commonly used frequencies are: i) intensive, when two consecutive ejaculates (within 15-30 min) are collected three or more times per week; ii) semi-intensive, when two successive ejaculates are collected twice a week; and iii) extensive, if only two successive ejaculates are collected once a week (Arroita et al., 2000a).

Several studies have compared the effect of different collection frequencies on the number of doses produced per male weekly and their seminal quality. These studies agree in that high collection frequencies lead to a reduction in ejaculate volume and sperm concentration as well as a decrease in number of successful solicitations per male (Bencheikh, 1995; Lopez et al., 1996; Nizza et al., 2003). However, semi-intensive collection frequency could lead to obtain a higher total number of sperm produced per male weekly than the extensive one (Desjardins et al., 1968; Bencheikh, 1995; Nizza et al., 2003).

Bencheikh (1995) reported that increasing ejaculate collection frequency leads to a reduction in sperm motility and percentage of live spermatozoa. However, Arroita et al. (2000b), Mocé et al. (2000) and Nizza et al. (2003) reported similar seminal quality performance -percentages of motility, abnormal spermatozoa, cytoplasmic droplets and normal acrosomes- in the three types of ejaculate collection frequencies.

Castellini et al. (2006) denoted that a high collection frequency increased the presence of plasma seminal droplets in the ejaculates probably due to the over-stimulation of the prostate gland. The function of these seminal droplets is still unknown but they seem to affect motility and capacitation of sperm and sperm deterioration during storage.

The ejaculate collection frequency affects not only production and seminal characteristics but also their levels of variation. Thus, Bencheikh (1995) reported in rabbits that the ejaculate collection frequency had an influence in the male repeatability for some seminal traits. Sperm motility and percentage of live spermatozoa repeatabilities were greater in intermediate or intensive rhythms than in extensive rhythm, but volume and sperm concentration of the ejaculate were more repeatable in extensive rhythm. On the other hand, Desjardins et al. (1968) indicated that differences among bucks in total number of sperm produced per week were magnified by the more intensive ejaculation frequencies. Therefore, in order to guarantee production and quality of AI doses, the collection frequency should be established taking into account its effect on both the mean and the variation.

To our knowledge there are few studies reporting the effect of ejaculate collection frequency on male fertility and prolificacy. Gregoire et al. (1958) compared two groups of rabbits that 
followed a different collection frequency: 1 ejaculate weekly or 1 ejaculate daily. They postulated that ejaculates could be collected as frequently as once a day for as long as 10 months without impairing their libido, sperm production or fertility. However, the reduced number of animals and data used in this experiment could presumably explain the not differences between the two types of collection frequencies. Adams and Singh (1981) indicate that, at least over short periods, increasing ejaculate extraction was compatible with satisfactory fertility but this practice reduced semen production.

The type of artificial vagina and its temperature could influence the ejaculate collection and therefore, male libido. It seems that a vagina with a wider collection orifice favours the success of the solicitation (Boiti et al., 2005).

Moreover, previous stimulation of bucks, such as placing a doe at the top of male's cage or grouping males before collection can improve the efficiency of collection (Lopez et al., 1996; Boiti et al., 2005).

Concerning feeding practices, specific protocols for improving male seminal production and reproductive efficiency have not been clearly established. However, some recommendations and feeding requirements concerning the quantity and quality of bucks' diets have been published (Boiti et al., 2005; Castellini, 2008). Ad libitum feeding is positively associated with male libido and number of spermatozoa per ejaculate (Maertens and Luzi, 1997). However, a commercial diet with low energy content is preferable to prevent excessive male fattening (Boiti et al., 2005). Concerning feed composition, some general recommendations have been given: a $15 \%$ of crude protein content is recommended for a correct sperm production, a balanced fatty acid composition for ensuring sperm membrane fluidity, low cholesterol content for ensuring a normal spermatogenesis and supplementing diets with antioxidant molecules can contribute in reducing sperm oxidative damage (reviewed by Castellini, 2008).

Finally, the use of proper extenders and protocols for dose conservation (refrigeration, freezing) also affect the efficient production of fertile doses. As storage time of AI doses increases, oxidative processes associated to sperm metabolism also increase, reducing the fertility potential of AI doses (Vishwanath and Shannon, 1997; Castellini et al., 2000). In rabbits, time and storage conditions affect sperm quality (Rosato et al., 2006), fertility and prolificacy (López et al., 1996; Roca et al., 2000).

\section{Environmental conditions}

Climatic conditions also affect male and female reproductive performance. Because of the global warming and their projected continuation, producing under heat stress conditions is 
going to be challenge for the future especially if we consider that the major part of the increase in world animal production should take place in the tropical area (FAO, 2006).

Seasonality is mainly determined by changes in temperature, humidity and daylight hours in a year. Wild rabbits (Orictolagus Cuniculus) in the European latitude have a marked seasonality in their reproductive cycle and their fertility follows daylength cycles (TheauClément et al., 1998).

Seasonal effects on reproduction have been frequently estimated under commercial farm conditions. However, interpretation of these effects and comparison of results obtained in different studies is not straightforward. Several studies have analyzed the effect of seasonality on buck reproductive performance, and have established that in summer and beginning of autumn males have lower libido, higher number of rejected ejaculates, fewer ejaculate volume and sperm concentration, higher percentage of sperm abnormalities and acrosomal damages compared to winter (Panella and Castellini, 1990; Alvariño, 2000; Nizza et al., 2003; Safaa et al., 2008). In addition, variables related to morphological and functional maturity of testis seemed to indicate that animals born in warm seasons could have different sexual development pattern compared to those born in cold seasons (García-Tomás et al., 2009).

Frangiadaki et al. (2003) compared the effect of seasonality on the reproductive performance of does under commercial farm conditions in Greece. They found that litter size at birth was lower in summer than in winter (6.9 vs 7.8 kits born, respectively). In Egypt, conception rate was lower in summer than in winter (-10\%; Marai et al., 2006) whereas kindling interval and litter size remained unaffected by the hot Egyptian season. However, other studies performed in Egypt reported that severe heat stress in summer adversely affected litter size (Ayyat et al., 1995; Marai et al., 2001; Iraqi et al., 2007).

Important efforts have been made in modern rabbit farms to control indoor photoperiod and temperature in order to reduce reproduction problems associated to seasonality.

Daylength has an effect on the hypothalamus-pituitary axis and consequently on hormonal release and spermatozoa production (Theau-Clément et al., 1994). Their negative effect on reproductive performance can be reduced through the use of artificial lighting programs. In Europe, commercial rabbit producers adopted a constant 16 hours light: 8 hours darkness because of the positive effects on spermatogenesis and on doe reproductive performance (reviewed by: Theau-Clément et al., 1998).

Extreme temperature and humidity conditions have also a negative effect on reproductive performance of several livestock species. With $\mathrm{AI}$, sperm is more exposed to the surrounding environment (during ejaculate collection, dose preparation and administration) than in 
natural mating. Therefore, not only animal exposure to high temperature should be avoided, but also temperature changes experienced by ejaculates (Boiti et al., 2005).

Environmental temperature or the temperature-humidity index (THI; that combines temperature and relative humidity; LPHSI, 1990; Marai et al., 2002) are descriptors commonly used to quantify the effect of heat stress on several species. The THI was first created to assess thermal comfort in humans (Thom, 1958) but, as sensitivity to the environmental conditions differs among species, different THI indexes have been developed for different species or breeds (Marai et al., 2002; Bohmanova et al., 2007; Marai et al., 2007).

Heat stress occurs when any combination of environmental variables lead to a higher body temperature than the normal body core temperature (ranging from 35 to $39^{\circ} \mathrm{C}$ in mammals; Hansen, 2009). Air temperature, but also solar radiation, wind, precipitation and specially relative humidity, contribute to the warmth feeling of the animal. In rabbits, the number of functional sweat glands is scarce and its fur does not allow easy perspiration. Therefore, under heat stress conditions, rabbits try to dissipate the excess of temperature by increasing respiration rate, changing body position and loosing heat via ear lobes (Harkness, 1988). When those mechanisms are not enough to dissipate excess body heat other mechanisms are activated (i.e. redistribution of blood flow and reduced feed intake). Nevertheless, heat stress leads to slow growth, disease susceptibility and reproductive performance impairments.

In bucks, testosterone concentration, spermatogenesis, libido and some seminal traits are traits negatively affected by heat stress (see review by Marai et al., 2002). An increase in testicular temperature reduces sperm production and motility, and increases sperm abnormalities (Hansen, 2009). Some authors have suggested that the spermatocyte and spermatid are the most temperature sensitive cell stages of the spermatogenesis. In rabbits, Finzi et al. (1995) compared the characteristics of the spermatozoa from ejaculates obtained in consecutive weeks in males moved from thermo neutral to heat stress conditions in a climatic chamber. They concluded that the stage of spermatid formation in the seminiferous tubules was the critical period towards the formation of sperm abnormalities. Roca et al. (2005) analyzed under commercial conditions the effect of THI on seminal traits (sperm concentration, sperm abnormalities and acrosome integrity). According to the time elapsed between the THI stress moment and the occurrence of an impairment in semen quality, they suggested that spermatogenesis but not the epididymus transit was affected by heat stress. However, their results should be taken cautiously because of possible confounding effects of season, light treatment and THI. In mice, applying heat stress in testis and epididymus, sperm was produced with defective chromatin (Banks et al., 2005). Oxidative stress seems to be the major reason of cell damage during spermatogenesis because it causes apoptosis and altered DNA (in mice: Banks et al., 2005; Pérez-Crespo et al., 2008). Sperm with damaged DNA may 
contribute to early pregnancy loss due to abnormal embryo development (Saacke et al., 2000; D'Occhio et al., 2007; Paul et al., 2008).

In rabbits, cold to moderate THI negatively affected some quantitative and qualitative semen traits (Garcia-Tomas et al., 2008) despite the fact that mammals tolerate better low than higher body temperatures (Hansen, 2009).

Heat stress conditions also have a detrimental effect on the processes involved in doe reproductive performance (Marai et al., 2002). As it occurs with male sperm production, the reviewed studies seem to indicate that there are periods of female reproductive cycle in which they are more sensitive to heat stress than others. Exposure to heat stress before insemination could have a negative effect on female reproductive performance due to higher embryonic degeneration compared to non-stressful conditions (Cheng et al., 1999). A reduction in the development of mature follicles and in the number of developing oocytes has been observed in rabbits during summer heat stress (Yassein et al., 2008). It has also been reported in cattle and goats that heat stress affects follicular dynamics, ovulation rate, steroid secretion and gene expression (Doney et al., 1973; Roth et al., 2001; Argov et al., 2005; Roth, 2008). During insemination, a female hyperthermic reproductive tract can also affect the fertilizing ability of the sperm and the posterior embryo survival (Howarth et al., 1965; Hansen et al., 2001). Pre and peri-implantation embryonic development stages seem to be the most sensitive periods to thermal stress (Putney et al., 1988; Ealy et al., 1993; Hansen et al., 2001). However, embryo susceptibility to heat stress decreases with time up until developing thermotolerance (Ealy et al., 1993; Hansen, 2009). A threshold of thermo-tolerance exists in rabbit pre-implantation embryos (Makarevich et al., 2007). Once the embryo reach the uterus, its survival under heat stress conditions has been associated more frequently to maternal physiology than to the embryo (Hansen, 2009).

The detrimental effects of heat stress on conception rate and litter size have been described by several authors in rabbits, especially in countries with hot climate conditions (Sittmann et al., 1964; Marai et al., 2006; Yassein et al., 2008). For example, litter size at birth was about 1 kits/litter higher for does kept at an average temperature of about $20^{\circ} \mathrm{C}$ than for does kept at constant $30^{\circ} \mathrm{C}$ (Papp and Rafai, 1988; Fernández-Carmona et al., 1995). In another work, Fernández-Carmona et al. (1997) also found a higher difference in litter size at birth (about 2 kits/litter) for does under a constant environmental temperature of $30^{\circ} \mathrm{C}$ than for does at $18^{\circ} \mathrm{C}$ on average.

It is important to note that most of those studies used climatic chambers or in vitro assays under extreme conditions of high and constant temperature. It is difficult to extrapolate those results to commercial farm conditions, where extreme temperatures are avoided and there is a wide range of daily temperature which allows reaching termoneutrality at night, in some 
regions. These farm conditions facilitate animal recovering from heat stress since rabbits are active and eat at night (Prud'hon, 1975).

The negative effect of heat stress is particularly marked on fertility of high producing dairy cows in warm areas (Al-Katanani et al., 1999; Jordan, 2003). Therefore, several studies in cattle have been focused on determining the most temperature sensitive periods around the insemination time capable of affecting reproductive performance. In those studies, different heat stress descriptors were calculated in different periods or particular moments before, after and during the AI day. Ravagnolo and Misztal (2002) found that THI on the day of insemination showed the highest effect on non-return rate at 45 day, followed by 2 days prior, 5 days prior, and 5 days after AI whereas no relationship was found with THI at 10,20, and 30 days after insemination. García-Ispierto et al. (2007) concluded that the period comprised from 3 days to 1 day after AI was the most climatic sensitive period affecting cow fertility. However, García-Ispierto et al. (2007) included in the same multiple regression model month or period of the year effect, several temperature variables (mean and maximum temperatures) as well as THI calculated in different periods around the IA time for performing variable selection. This could lead to obtain confounded estimates of these effects due to co-linearity problems.

\section{Genetic type of female and its physiological status at $\mathrm{AI}$}

The female genotype (breed) also influences fertility and prolificacy. As there exists several maternal lines of rabbits that are commonly selected on litter size, differences in reproductive performance can exist among types of crossbreed does. Baselga et al. (2002) analyzing the reproductive performance of does from three maternal lines and their complete diallelic cross found differences in direct genetic effects among lines. Santacreu et al. (2000) found that two experimental lines divergently selected for uterine capacity had different litter sizes $(2.63$ kits) mainly due to differences in the number of implantated embryos.

The reproductive status of female could also affect fertility and prolificacy. In semi-intensive and intensive production systems, rabbit does can be inseminated whilst suckling their litter because they are able to overlap lactation with the next gestation. However, lactation decreases female receptivity, ovulation rate and frequency, and increases number of embryo deaths and postimplantation mortality (Theau-Clément and Roustan, 1992; Fortun and Bolet, 1995; Castellini and Lattaioli, 1999). Some of the negative effects of lactation on fertility can be partially alleviated when ovulation is artificially induced. Using artificial ovulation induction and natural mating, lactating does from paternal lines had lower fertility than the non lactating 
ones, but not females from a maternal line (Piles et al., 2005). The lowest conception rate $(22 \%)$ and litter size (8.4) were observed in non-receptive and lactating, but not induced does at the time of AI. In contrasts, the highest fertility (approximately 70.3) and litter size (approximately 10.8) were observed in receptive does regardless of their lactation status (Brun et al., 2002b). However, in most of commercial AI, female receptivity is artificially induced in order to synchronize physiologically many females for AI. Finally, parity order is another component of the reproductive status of females with an effect on reproductive performance. Viudes-de-Castro and Vicente (1997) reported lower conception rates in lactating primiparous does than in nuliparous or lactating multiparous does. They also reported lower litter sizes in primiparous does than in multiparous does.

\subsubsection{Genetic factors}

The existence of genetic variation can be used to improve production of potentially fertile semen doses in different ways: 1) by using bucks from breeds with the best reproductive performance for the traits of interest, 2) by using crossbreed males in order to take advantage of the benefits of the possible heterosis and complementarity between traits in the different lines, and finally, 3) through the use of genetic selection within line for one or several traits related to male reproductive performance or semen production.

\section{Genetic variation between lines}

Vicente (2000) found lower sperm production, less motility and more acrosomal defects in a paternal line selected for growth than in three maternal ones. In the same study, fertility rate did not differ among lines but prolificacy did, probably due to the selection process of the maternal lines. Theau-Clément et al. (2003) compared sperm production and quality in three maternal lines of rabbits and found differences in collection rate, ejaculate volume, sperm concentration, $\mathrm{pH}$ and several motility traits. They also concluded that there were also differences in the variability of semen characteristics between and within bucks for some of the seminal traits analysed.

Brun et al. (2006) did not find differences in male libido between two lines divergently selected for body weight at 63 days but reported that males from the lighter line had higher ejaculate volume, sperm motility and number of ejaculates suitable for AI but lower sperm concentration than males from the heavier line. In a posterior study, the same lines were compared in fertilizing ability and no differences were found (Theau-Clément et al., 2007). 
In another study, Brun et al. (2002a) compared sperm production and quality in two maternal lines and only found differences for ejaculate volume and percentage of motile spermatozoa, probably due to positive maternal effects for those traits reported in one line.

Garcia-Tomás et al. (2006c) found differences in direct genetic effects for some seminal traits in two rabbit lines highly selected for growth rate: one of the lines seemed to present better seminal production traits (sperm concentration and total number of sperm in the ejaculate) and the other one presented, in general, better seminal quality traits (fewer presence of carbonate deposits in the ejaculate and better sperm morphological traits). In the same study, favourable maternal effects were reported in one of the lines for ejaculate and sperm quality and production traits. The maternal effects in the other line favoured only sperm volume. The same authors reported that males from the line with better seminal quality traits presented better fertility (Garcia-Tomás et al., 2006a). This could be explained by the unfavourable maternal effects encountered for this trait in the other line. No relevant differences were found for number of kits born alive or stillborn.

Males from rabbit maternal and paternal lines could have different sexual development patterns according to differences found in their percentages of seminiferous tubules with presence of spermatozoa observed in different ages (García-Tomás et al., 2009).

\section{Crossbreeding parameters}

An improvement in the production of potentially fertile doses could be achieved through the use of crossbreed males thanks to a possible positive heterosis as well as complementarity between parental lines.

Brun et al. (2002a) reported positive heterosis for sperm concentration, total number of sperm per ejaculate, mass motility and percentage of motile spermatozoa when they analysed semen characteristics in two maternal lines and their reciprocal crosses. However, the heterotic effects for seminal traits obtained in crosses between two paternal lines of rabbits were of low relevance and only favourable for the presence of sperm with cytoplasmic droplets.

Brun et al. (2002b) found that crossbreed males and females from two rabbit maternal lines had better conception rate and prolificacy than the purebred ones. However, it was not possible to know from that study whether those differences were due to the effect of crossbred males or crossbreed females. Using paternal lines, García-Tomás et al. (2006a) found unfavourable individual heterosis effects for male fertility but not for total number of kits born alive or stillborn. Therefore, they concluded that the use of a crossbreed male for improving the production of fertile doses did not present more advantage than the use of a 
purebred one and suggested the use of specialized males to improve dose production in the AI centres.

In pigs, the use of a crossbreed male as a terminal sire is widespread. Crossbred boars reached sexual maturity earlier, showed greater weight at a constant age and greater testicular weight and total spermatozoa than purebred ones (Neely and Robison, 1983; Smital et al., 2004). Accordingly, Buchanan (1987) reported that crossbreed boars showed stronger libido, greater semen volume, higher motility, lower abnormal spermatozoa and higher pregnancy rate than purebred boars but this difference in performance diminished at adult age. Finally, Smital et al. (2004) reported favourable heterotic effects in sperm output for certain crossing combinations.

Crossbreed bulls showed a small better performance for several seminal traits and lower age at puberty (Thrift and Aaron, 1987).

\section{Genetic variation within line}

Genetic selection of paternal lines used for AI could be an alternative strategy to improve production of fertile doses from bucks with high genetic merit for growth and feed efficiency. In rabbit, paternal lines used for insemination have been highly selected for growth traits and no emphasis have been placed in semen production and reproductive performance.

With this purpose, it is necessary to determine first what are specifically the traits (or the trait) that should be improved, which in turns depends on their genetic variance, their genetic correlation with all the traits involved in the production of doses, as well as with growth and feed efficiency traits, and on their economical importance. In this section, a review of the information available in the literature concerning genetic parameters of these traits is provided.

\section{Genetic parameters of seminal quality and production traits}

In general, a wide range of heritability $\left(\mathbf{h}^{2}\right)$ and repeatability estimates for the seminal traits can be found in the literature ranging from extremely low to high values $(0.09-0.65$, reviewed in bulls by: Robinson and Buhr, 2005). The variation in the magnitude of this parameter is due to several factors such as: i) different genetic composition of populations of bucks in experiments; ii) variation in defining the trait, which in some cases consist of means of observations of two consecutive ejaculates or means of several records per male, whereas in other cases corresponds to individual ejaculates (Ducrocq and Humblot, 1995; Wolft, 2009); and iii) the possible effect of collection frequency on the individual variation of seminal traits. 
On the other hand, the $\mathrm{h}^{2}$ estimates are imprecise in most of the reviewed studies. This is partly due to analysing small experimental data sets. Moreover, a large amount of environmental variation originates during semen manipulation and time to evaluation and also the subjective manner in which some of the seminal traits are evaluated.

In rabbits, Panella et al. (1994) reported that $\mathrm{h}^{2}$ of male libido was 0.30 when this trait was classified in 3 categories (no collection, collection after $5 \mathrm{~min}$ and intermediate collection). However, in that work all the genetic parameters estimates for seminal traits were unusually high probably because no other permanent effects were included in the model. Khalil et al. (2007) defined male libido in 5 classes (from 1 for low libido to 5 for strong libido) and they obtained $\mathrm{a} \mathrm{h}^{2}$ estimate of 0.17 from data from a heterogeneous population constituted by bucks belonging to two rabbit lines and their reciprocal crosses. In pigs, Flowers (2008) advised against improving those traits trough genetic selection because of the low phenotypic variation obtained in several studies for male libido and mating behaviours.

To our knowledge, there are no $\mathrm{h}^{2}$ or repeatability estimates for qualitative characteristics of the rabbit ejaculate such as the presence of urine, calcium carbonates deposits and gel plugs. However, because of some of these traits are considered major criteria for ejaculate rejection in AI centres (Brun et al., 2002a; Theau-Clément et al., 2003; Garcia-Tomás et al., 2006c), it would be of interest to determine their genetic determinism or, at least, to determine the magnitude of their repeatability in order to be able to make decisions concerning buck replacement in the AI centres.

The estimated $\mathrm{h}^{2}$ for ejaculate volume and sperm concentration in rabbit ranged from 0.06 to 0.13 and from 0.08 to 0.10 , respectively (Brun et al., 2009; Lavara et al., 2011). Moderate values of repeatability were found for these traits in a heterogeneous population constituted by purebred and crossbred bucks obtained from two paternal lines (0.38 \pm 0.03 and 0.39 \pm 0.03 , respectively; Garcia-Tomás et al., 2006b). O’Ferrall and Meacham (1968) also obtained a moderate value of repeatability (0.29) for ejaculate volume in a New Zealand population of bucks. The value of this parameter could be affected by the collection frequency (Bencheikh, 1995).

Several studies in different livestock species have estimated the genetic correlation $\left(\mathbf{r}_{\mathbf{g}}\right)$ between ejaculate volume and sperm concentration indicating the existence of a genetic antagonism: in pigs (-0.60 on average; Smital et al., 2005; Wolft, 2009), bulls (-0.31 on average; Karoui et al., 2011; Ducrocq and Humblot, 1995; Basso et al., 2005), sheep (-0.36 on average in adult males; Rege et al., 2000; David et al., 2007b) and goats (-0.33 on average; Furstoss et al., 2009). In rabbits, the only reported estimate of the $r_{g}$ between sperm concentration and ejaculate volume was very imprecise and cannot be considered to be different from zero (0.38 \pm 0.45 ; Brun et al., 2009). Having an accurate estimate of this 
parameter is important because both traits determine the total amount of sperm produced per ejaculate, which is one of the traits involved in efficient production of AI doses. Lavara et al. (2011) obtained a low estimate (0.07) of the $\mathrm{h}^{2}$ for total number of sperm per ejaculate, which could be explained by the existence of this genetic antagonism between ejaculate volume and sperm concentration.

The only available estimates of $\mathrm{h}^{2}$ for semen $\mathbf{p H}$ were obtained by Brun et al. (2009) who obtained a value for this parameter of 0.06 in a paternal line of rabbits and Khalil et al (2007) who obtained a value of 0.12 in a population of crossbred and purebred bucks. The published repeatability estimates for this trait are variable. Bencheikh (1995) compared seminal characteristics in males under different collection frequency and obtained estimates that ranged from 0.07 to 0.24 , whereas Brun et al. (2009) obtained a value for this parameter of 0.17 in purebred bucks and Garcia-Tomás et al. (2006b) 0.38 in a population of purebred and crossbred bucks, both under a extensive collection frequency.

Low $\mathrm{h}^{2}$ values have been obtained for sperm motility traits when they have been evaluated in a subjective manner. In rabbits, the $\mathrm{h}^{2}$ of mass motility was estimated to be 0.05 (Brun et al., 2009 ) and the repeatability ranged from 0.24 to 0.37 in a population of crossbreed and purebred bucks (Garcia-Tomás et al., 2006b; Brun et al., 2009). The repeatability for individual motility was estimated to be 0.35 (Garcia-Tomás et al., 2006b). Measurements of percentage of motile spermatozoa evaluated with a Computer-Assisted Semen Analyzer system provided higher estimates of $\mathrm{h}^{2}$ that ranged from 0.16 to 0.18 in two paternal lines of rabbits (Lavara et al., 2008b; Brun et al., 2009). Moderate to low $\mathrm{h}^{2}$ estimates were obtained for some sperm kinetic parameters obtained from CASA systems (0.02 to 0.14; Lavara et al., 2008b; Brun et al., 2009).

Regarding measurements of morphology of the spermatozoa and sperm head morphometry traits assessed with the Automated Sperm Morphometry Analysis system, only Lavara et al. (Lavara et al., 2008a) reported $\mathrm{h}^{2}$ estimates obtained in a paternal line of rabbits: 0.25 for percentage of spermatozoa with normal apical rigde, 0.65 for percentage of sperm morphological abnormalities, from 0.08 to 0.52 for several sperm head morphometry traits.

\section{Genetic parameters of fertility and prolificacy}

Because of the female has a long-term effect on the formation of viable offspring, fertility and prolificacy traits in prolific species have been commonly attributed only to the female (Berger, 1998). Thus, there are few studies that analyse the male contribution to these traits.

Concerning fertility in prolific species, Varona and Noguera (2001) estimated the contribution of male and female to environmental and genetic variation for fertility defined as the success or the failure to conception after AI in pigs. They obtained very low estimates of $h^{2}$ for male 
and female fertility ( 0.03 and 0.04 , respectively) and a negative genetic correlation for both traits (-0.51). Using the same threshold model, Piles et al. (2005) analyzed fertility after natural mating in two rabbit lines (paternal and maternal). They found that $\mathrm{h}^{2}$ for male fertility was 0.01 in both lines and male permanent effect did not exceed the $7 \%$ of the total amount of variation in none of them. Regarding the female contribution to fertility, they also obtained low $\mathrm{h}^{2}$ estimates in both lines (around 0.06 ), whereas the female repeatability was estimated to be 0.18 and 0.30 in the paternal and the maternal line, respectively. Contrary to the results obtained in pigs, the genetic correlation between male and female contributions to fertility obtained in this species was found to be moderate to high and positive ( 0.73 and 0.43 in the paternal and maternal lines, respectively). However, genetic correlation estimates between low heritable traits should be taken with caution. Using random regression models to analyze fertility (defined as the proportion of fertile eggs) over the laying period in broiler chickens, Wolc et al. (2009) found that both sexes contributed to fertility. The $\mathrm{h}^{2}$ estimates of weekly records were found to be around 0.10 and 0.07 for the male and female contributions to fertility, respectively, remaining constant toward the period of productive life. Male and female genetic effects for this trait had a positive but small correlation (0.15).

Heritabilities and repeatabilities corresponding to other measurements of fertility have also been found to be low. Thus, the female $\mathrm{h}^{2}$ for kindling interval in rabbit ranged from 0.02 to 0.08 (Moura et al., 2001; Baselga et al., 2003; Ragab and Baselga, 2011). In pigs, sow $\mathrm{h}^{2}$ estimates for fertility defined as different time intervals such as number of days from weaning to service, from weaning to conception, and from weaning to farrowing were $0.12,0.08$ and 0.08, respectively (Adamec and Johnson, 1997). In dairy cows, $\mathrm{h}^{2}$ for non-return-rates are generally low ranging from 0 to 0.05 (Weller and Ron, 1992; Boichard and Manfredi, 1994; Thaller, 1998; Weigel and Rekaya, 2000) whereas female $\mathrm{h}^{2}$ for different intervals of time (calving interval, calving to first insemination, days open, days from first AI to conception) are slightly higher ranging from 0.05 to 0.15 (Thaller, 1998; Weigel and Rekaya, 2000; ToghianiPozveh et al., 2009; Yagüe et al., 2009). In cattle, fertility measurements from higher parities show higher $\mathrm{h}^{2}$ estimates, except for heifer fertility (Thaller, 1998). Male genetic component is commonly not taken into account for the genetic evaluations of cattle fertility in EEUU and only a male permanent effect is included in the model in order to obtain a phenotypic prediction of the bulls to perform the selection (Weigel and Rekaya, 2000; Clay and McDaniel, 2001; Averill et al., 2004). Kuhn and Hutchinson (2008) thought that it could be useful for improving the precision of the prediction of the female fertility, to expand the male component with a genetic effect in the model. Although the precision of the female fertility prediction was slightly improved, the obtained male $\mathrm{h}^{2}$ for fertility was almost zero and, therefore, authors suggested not to include a male genetic component in the model for future female fertility predictions. Similarly, Boichard and Manfredi (1994) found that the service sire permanent 
effect explained the 0.08 and the 0.13 of the total phenotypic variance using a linear and a threshold model to analyse conception rate, respectively. A.-Ranberg et al. (2003) analysed $56-d$ non-return rate in virgin heifers and included a sire and a service sire genetic effects. The obtained direct $h^{2}$ and the $h^{2}$ of the service sire effect for this trait were 0.01 and 0.002 , respectively. Both effects had a correlation of 0.26 .

Estimates of female $\mathrm{h}^{2}$ for litter size traits are generally low as it was reported by Blasco (1996) in his review and in posterior published researches (Lukefahr and Hamilton, 1997; García and Baselga, 2002b; Piles et al., 2006; Ragab and Baselga, 2011). In general, $\mathrm{h}^{2}$ estimates for litter size traits tend to decrease as far from birth those traits are measured. Thus, estimates of female $\mathrm{h}^{2}$ under a repeatability model in those works ranged from 0.10 to 0.14 for total number of kits born, from 0.07 to 0.12 for number of kits born alive, from 0.04 to 0.11 for total number of kits weaned, and from 0.05 to 0.08 for number of marketed rabbits. On the other hand, greater $\mathrm{h}^{2}$ estimates were obtained for prolificacy measurements in different parities considered to be different traits than when they were considered different measurements of the same trait. In pigs, the female $\mathrm{h}^{2}$ estimates for prolificacy traits also ranged from zero to 0.15 (Rydhmer, 2000; Hanenberg et al., 2001; Peskovicová et al., 2002; Holm et al., 2005).

Male genetic contribution to prolificacy traits is also small. Percentages of variation due to male effects for litter size traits after natural mating were 3\%, $2 \%$ and $1 \%$ for total number of kits born alive, total number of kits born and for total number of weaned, respectively (Piles et al., 2006). In pigs, See et al. (1993) reported that the proportion of phenotypic variance due to male genetic effects for number of piglets born alive was low (0.01). In accordance, in three lines of pigs, boar $\mathrm{h}^{2}$ for total number of piglets born and total number of piglets born alive ranged from 0 to 0.04 and from 0.01 to 0.03 (van der Lende et al., 1999). Hamann et al. (2004) obtained a male $\mathrm{h}^{2}$ for number of piglets born alive of 0.05 and 0.03 in the first and subsequent parities, respectively.

\section{Genetic correlation between semen quality traits and male reproductive performance}

The indirect selection of male reproductive performance through the use of seminal quality traits has been proposed as an alternative to overcome some of the difficulties associated with the direct selection for this trait. Obtaining male measurements of seminal traits would be cheaper and more precise than obtaining data of their reproductive performance in the farms. In addition, it could be possible to obtain a higher response in male reproductive performance as a correlated response to selection for seminal traits than the one obtained by direct selection if certain conditions are given. We can assume that generation interval required for 
obtaining male reproductive performance records is approximately the same as the one required for obtaining seminal traits measurements (i.e. response to selection can be calculated for the same unit of time in both cases). Hence, according to Falconer and MacKay (1996) the direct and correlated response to selection for male reproduction performance would be $D R=i h_{F} \sigma_{A F}$ and $C R=i h_{s} r_{g} \sigma_{A F}$, respectively. Where $i$ is the intensity of selection and $h_{F}$ and $h_{S}$ are the square root of the $\mathrm{h}^{2}$ of male reproductive performance and the seminal trait, respectively. The $\sigma_{A F}$ is the additive genetic standard deviation for male reproductive performance and $r_{g}$ is the geneti c correlation between male reproductive performance and the seminal trait. Performing indirect selection for male reproductive performance instead of direct selection could be interesting if $h_{S} r_{g}>h_{F}$ (i.e. $C R / D R>1$ ). Assuming that the same $i$ is applied in both types of selections, this ratio only depends on the $\mathrm{h}^{2}$ of the traits and on their genetic correlation. Figure I.10 shows the ratio between correlated and direct response for male reproductive performance ( $C R / D R$; first column) and the correlated response in units of standard deviation of the trait ( $C R / \sigma$; second column) under different hypothetic scenarios defined by the $r_{g}$ and the $\mathrm{h}^{2}$ of both traits. Only moderate to high values of $r_{g}$ were considered and only 4 different values taken from the literature were assumed for $h_{F}^{2}$ while the values of $h_{s}^{2}$ ranged from 0 to 0.6 . The highest $C R / D R$ ratio is achieved when $h_{F}^{2}$ is very low and it increases with high $r_{g}$ and $h_{s}^{2}$ values. However, the magnitude of $C R$ is low (lower than 0.10 units of standard deviation of male reproductive performance) in a plausible scenario (with $h_{F}^{2}=0.05, h_{s}^{2}=0.25$ and $r_{g}=0.7$ ). 

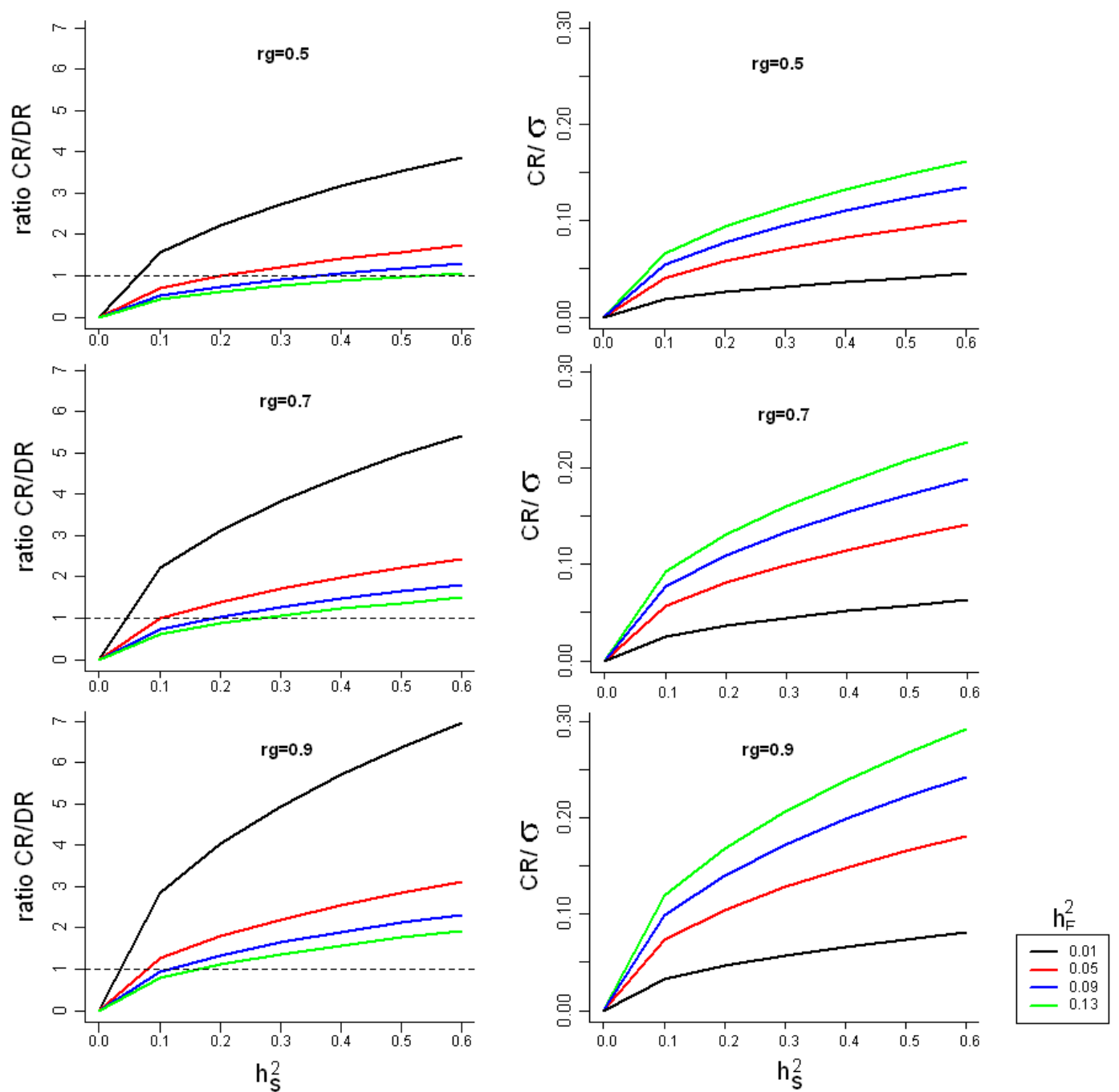

Figure I.10. Ratio between correlated (CR) and direct response (DR) and the correlated response in standard deviation units $(C R / \sigma)$ under different hypothetic scenarios of genetic correlation $\left(\mathrm{r}_{\mathrm{g}}\right)$ and heritability of the seminal trait $\left(\mathrm{h}_{\mathrm{s}}\right)$ and male fertility $\left(\mathrm{h}_{\mathrm{F}}\right)$

Some seminal traits have been found to be heritable but it is not clear that a correlated response in male fertility could be achieved since their relationship with this trait is not clearly established at a phenotypic and genetic level. The predictive ability of male fertility from semen quality traits usually recorded (in the conditions they are recorded) is very low. Therefore, it is not clear which is the trait or the combination of seminal traits that should be improved. In the case of using several traits, the prediction of buck fertility obtained from them using proper models and statistical procedures, could be used as selection criteria. However, its genetic determinism is probably even lower than that of the direct measurement of male reproductive performance.

To our knowledge there is no information in the literature regarding genetic correlations between semen traits and fertility and prolificacy in rabbits. In other species several studies 
have analysed the relation between seminal traits and the female component of the reproductive performance but no research has been encountered regarding the genetic relationship between seminal traits and male contribution to reproductive performance. Therefore, in those studies the genetic relationship can only be estimated via relatives. This makes the precision of the estimate very dependent on the relationship structure of the data (commonly sire-daughter). Genetic correlations between semen characteristics and sow litter traits have been analysed in two studies where some of the obtained results seemed to depend on the breeds and on the parity order (Smital et al., 2005; Wolf, 2010). Both studies showed a non relevant genetic correlation between sperm concentration and female contribution to litter size. Results of the two studies also agreed in the negative genetic correlation between total number of sperm and litter size whereas the genetic correlation between sperm abnormalities and litter size seemed to be breed specific. The genetic correlation between litter size and sperm motility was positive and negative in Smital et al. (2005) and Wolf (2010), respectively. In addition, Smital et al. (2005) obtained a negative genetic correlation between semen volume and litter size whereas the same figure was estimated to be positive in the first parity of one of the two breeds analysed by Wolf (2010). Finally, among several seminal traits analysed, conception rate was only positively correlated with sperm motility (Smital et al., 2005).

In bulls the scrotal circumference has been widely used as a selection criterion for improving cow fertility because several works have shown favourable genetic correlations with reproductive performance of the bull daughters (Moser et al., 1996; Van Melis et al., 2010). However, this correlation is not probably high enough for an effective selection (MartinezVelazquez et al., 2003).

\subsubsection{Genotype $x$ AI conditions interaction for male effect on reproductive performance}

From the reviewed studies, it can be concluded that the expected response to direct selection for the male contribution to reproductive performance after natural mating or after AI under commercial conditions is very low. Moreover, a correlated response by selection for semen quality traits could be very difficult to achieve. An alternative approach could be to find the AI conditions in which male genetic variability for this trait can be better observed (if they exist). Direct selection under these conditions should also lead to a correlated response in male reproductive performance under the conditions of semen utilization. 
At the phenotypic level, Amann and Hammerstedt (2002) addressed the controversial issue of detecting fertility differences among males. Figure I.11 (adapted from: Amann and Hammerstedt, 2002) shows a hypothetic dose-response curve of fertility as a function of the number of total sperm per insemination. The asymptotic part of the curve would correspond to the fertility after natural mating or after AI under commercial conditions: the use of high sperm dosage means that most of the males reach the threshold for fertility success, and therefore, little individual variation is observed. Using a very small amount of sperm would lead to the same effect on individual variation since most of the males are not able to fertilize

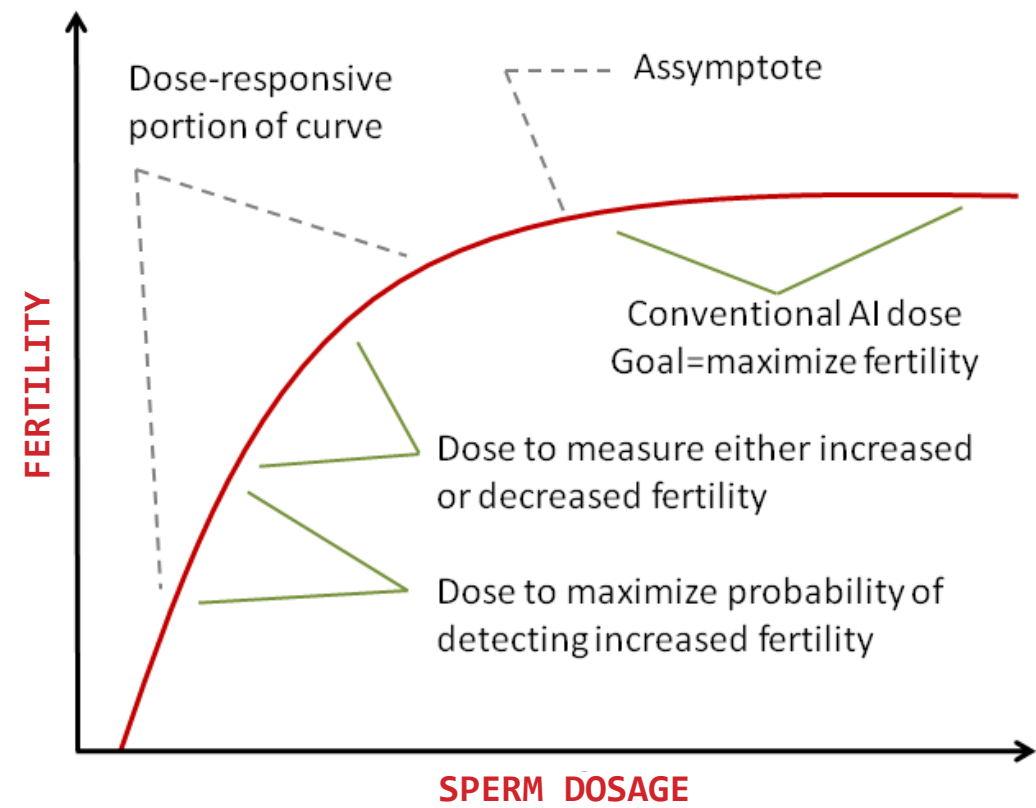

Figure I.11. Hypothetic dose-response curve of fertility as a function of the number of total sperm (adapted from: Amann and Hammerstedt, 2002).

The observed individual variation in fertility at high sperm dosage is due to the individual variation in seminal characteristics whose effect on this trait is independent of the amount of sperm in the AI dose. They are named "uncompensable" traits (Saacke et al., 1994; Den Daas et al., 1998; Saacke et al., 2000). Deficiencies in these characteristics render the sperm unable to maintain the fertilization process or subsequent embryogenesis once initiated. They are mainly related to alterations in the chromatin with an effect on the DNA stability (Saacke et al., 2000). However, there are other deficiencies in seminal characteristics whose negative effect on male reproductive performance can be overcome by increasing the amount of sperm used to inseminate. These seminal characteristics are named "compensable" traits. Deficiencies in these traits prevent the sperm access to or engagement with the ovum. Some examples of these traits are sperm motility, sperm viability, acrosomal normality and sperm abnormalities, 
as well as some functional and molecular characteristics related to the sperm hyperactivation and capacitation in the oviduct. As a consequence of this masking effect, variation in these traits does not contribute to the variation in male reproductive performance when the sperm dosage is high. For this reason, Amann and Hammerstedt (2002) suggested the use of a low number of sperm in the dose in order to obtain the most favourable conditions for detecting differences in fertility among males. This sperm dosage would correspond to the so-called "dose-responsive" portion of the curve (Figure I.11). Lengthening the storage period of the doses would also contribute favourably to enlarging the fertility differences among males because AI conditions would be more restrictive than if fresh semen had been used.

The optimum situation for detecting the highest amount of phenotypic male variability would be to obtain an average fertility of $50 \%$. However, this is not the case in dairy cattle, in which the conception rate had been reduced from $52 \%$ in the 1970 s to $34 \%$ by the end of the 1990 s (Washburn et al., 2002). In dairy cattle, there is almost no variation on fertility attributable to the male because, although inseminations are performed with frozen sperm, bulls have been highly pre-selected for seminal quality. Therefore, the low fertility rate is mainly due to female reproductive problems derived from management practices and high production. This is a clear example of the effect of other sources of variation not related to the male which greatly contribute to fertility results

If the effect of the AI conditions on the phenotypic variation of male reproductive performance also corresponds to an effect on the genetic variation for this trait, it would be possible to find the AI conditions which maximize the selection response. This would be a specific case of the existence of an interaction between the male genotype and the environment.

\section{Genotype x Environment interaction definition}

Under presence of genotype by environment interaction (GxE), phenotypic differences among individuals are not the same in different environments (Kolmodin, 2003). The environmental conditions could be described by one or several factors with an effect on the individual phenotype (temperature, humidity, sperm dosage, time of dose storage, etc) or by a global descriptor of a group of factors with an effect on the phenotype, such as the management system, herd or the AI conditions as a whole (which includes among others: the environmental conditions of the farm and management practices, female genotype, extender, sperm dosage, etc).

Figure I.12 shows four types of phenotypic response (P) of 3 individuals across an environmental variation (E). From left to right, in the two first panels, there is no GxE: in the first one there is no phenotypic response to the environmental variation because individual phenotypes remain constant across the environmental variation; in the second panel, although 
there is a phenotypic response to the environmental variation, the phenotypic differences among individuals remain constant (there is no individual variation in the effect of the environmental conditions). The GxE appear in the two last panels (there is an effect of the environmental conditions and individual variation in the effect of these factors):

in the third one, the phenotypic response changes according to changes in the environment, more variability is observed in certain environmental conditions than in others, which represents an scale effect of the GxE; in the fourth panel, phenotypic differences among individuals changes in sign depending on the environmental conditions leading to a re-ranking of the individuals because of their different phenotype expression in the different environmental conditions.

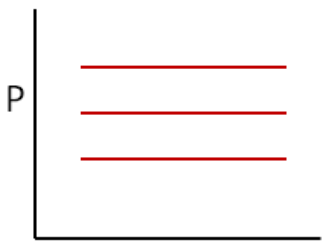

$E$

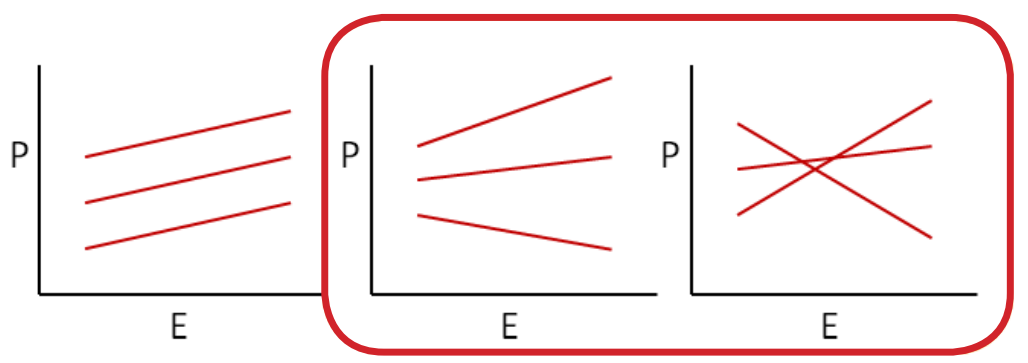

Figure I.12. Four types of phenotypic response $(P)$ of 3 individuals across an environmental variation $(E)$.

Breeders can profit from the existence of GxE. As a genetic progress is a function of the genetic variance, the expected response to selection could be higher under limited conditions of AI if higher genetic variance is observed (Falconer and MacKay, 1996). The deciding factor of the conditions that should be used for selection must come from the comparison of the genetic progress achieved under the conditions of utilizati on from selecting in different environments (Kolmodin, 2003).

\section{Methods for the analysis of GXE}

Phenotypic data of the same individual or relatives measured in different environmental conditions are required to test for the presence of GxE.

The existence of GxE can be detected in an ANOVA if relevant interaction exists between the environment and the genotype, both included as factors in the model. However, under a mixed model genotypes are defined by realizations of random variables (e.g. animals within a single population) and this approach is not applicable. In this case, two types of models (which differ 
in the way in which the environment is defined) can be applied to analyse GxE interaction: the Character State Model and the Reaction Norm Models.

\section{Character State Model}

In the Character State Model (Falconer, 1952), the phenotype measurements in the different environments are analyzed as different traits (or character states). Therefore, under this approach, the different environments are necessarily considered to be discrete factors.

In this model, the interaction variance $\left(\sigma_{G X E}^{2}\right)$ can be estimated from the genetic variances and covariances of the two traits (environments) according to the following formula (Mathur, 2002):

$$
\sigma_{G x E}^{2}=\frac{1}{2}\left(\sigma_{G_{1}}-\sigma_{G_{2}}\right)^{2}+\sigma_{G_{1}} \sigma_{G_{2}}\left(1-r_{g}\right)
$$

Where $\sigma_{G_{i}}$ is the genetic standard deviation in environment $i$. Differences in the magnitude of the genetic variances and genetic correlation different from 1 indicate the existence of GxE due to a scale effect (first component of the sum) or due to a re-ranking of individuals $\left(2^{\text {nd }}\right.$ component of the sum). The magnitude of the genetic correlation between the traits (environments) indicates how likely the same genes are modulating the phenotypic expression of the trait in the two environments.

The Character State approach has been widely used for studying the environmental sensitivity in cattle for productive (milk production, percentage of protein...), reproductive (fertility) and sanitary traits (somatic cell counts, presence of gastrointestinal parasites, etc) in which the environmental factors were defined by levels of production in herds, type of feeding and management systems (Van Vleck, 1963; Carabaño et al., 1990; Kolmodin et al., 2002; Boettcher and Fatehi, 2003; Fikse et al., 2003; Kolmodin et al., 2003; Petersson et al., 2005; Windig et al., 2006; Kearney et al., 2004). It has also been used by The International Bull Evaluation Service (INTERBULL) for the international genetic evaluation of dairy bulls, treating milk production in every country as a different but correlated trait.

\section{Reaction Norm Models}

A reaction norm describes the phenotypic expression of a genotype as a function of the environment.

Reaction Norm models are adequate for the analysis of GxE when the phenotypes change continuously through an environmental gradient i.e., temperature, humidity, nutrient 
availability, etc. Under this approach, each phenotype is expressed as a function over the environmental gradient and the coefficients of this function are assumed to have a genetic determinism. Therefore, different individuals can respond in a different way over the environmental gradient.

If genetic variation exists for the coefficients of the function, GxE exists because different individual sensitivity to the environment exists (Kolmodin, 2003). A change in the environmental sensitivity could be obtained either by direct selection on the coefficients of the function or as a correlated response to selection on the phenotypes within environments (Via et al., 1995). Although linear reaction norms are the most common models used to describe the phenotype over the environmental gradient, other quadratic or sigmoid shaped polynomial functions can also be used (Kolmodin, 2003).

In the reaction norm models it is assumed that the continuous gradient of environmental values defines an infinite number of character states that are related to each other by a covariance function. There are different ways to estimate the parameters of this covariance function:

One way is to choose several points among the longitudinal data treating the different points as different character states. Then the covariance matrix among those points is estimated, and, with the values of the function at each point, the parameters of the covariance function is calculated as a reduced model by for example least squared (Kirkpatrick and Lofsvold, 1989; Kolmodin, 2003). One of the inconveniences of this method is that previous knowledge of the covariance matrix for the elected character states is needed.

Another way to estimate the covariance function is to do it directly from the data by the usage of Random Regression models. In these models a polynomial function of regressors (environmental gradients) is included in the model nested within some random effect (e.g. additive effect) this fit will allow covariance components to change over the environmental gradient. Therefore, it allows modelling individual deviation from a fixed regression of the trait on the environment. In these models, the individual environmental sensitivity is defined as the first derivative of the polynomial function (that corresponds to the slope in a linear function) and the intercept of each individual function gives the level of the response variable in the absence of effect for the environmental descriptor. Random regression models have been used to analyse the environmental sensitivity of some traits such as growth, milk production, fertility, longevity, etc (Oseni et al.; Kolmodin et al., 2002; Windig et al., 2006). 
Finally, another approach is to use hierarchical models (Wakefield et al., 1994a). They allow estimating any type of function and the use of models that allow splitting the parameters in their genetic and environmental components. One of the advantages of this method is that the parameters of the fitted curve have a biological interpretation. Recently, they have been used for analysing non-linear functions in which the traits are affected only if the environment exceeds a certain threshold such as the effect of heat stress on milk production and on reproductive traits (Sánchez et al., 2009a; Sánchez et al., 2009b; Sánchez and Piles, 2010). Hence, individual variation could exist in the level of the response, in the threshold, and in the coefficients that describe the function over the environmental gradient.

If the environment presents a continuous gradient, the covariance function has several advantages over the character state approach. The first one is that when large amounts of records are collected at different points over the environmental gradient, only the coefficients of the function needs to be estimated. The second advantage is that the trait is described along the entire environmental gradient, rather than at specific points, even if data is not available in some points. Finally, measurements are used without being previously grouped in discrete environments (or characters) which leads to obtaining more precision in the estimation of the variance components (Kolmodin, 2003).

\subsection{The relationship between growth rate and the traits involved in the production of fertile doses}

Most of the males used for $\mathrm{AI}$ in the centres come from paternal lines of rabbits which have been highly selected for growth traits (de Rochambeau et al., 1989; Estany et al., 1992; Lukefahr et al., 1996; Larzul et al., 2003) in order to have good genetic merit for growth and feed efficiency. As males to be used for AI should also have good seminal characteristics, it is important to determine the genetic correlation of these traits with the selection criterion of the line in order to determine whether those traits could be affected by the selection for growth or not, and/or if it is feasible to include them in an index of selection for the improvement of the potentially fertile doses from males of paternal lines.

In rabbits, there is only one work reporting estimates of genetic correlation between growth traits and seminal traits. The genetic correlation between sperm concentration, ejaculate volume and total number of sperm produced per ejaculate with average daily gain during the fattening period was estimated to be of $-0.09,0.36$ and 0.17 , respectively, in a paternal line of rabbits (Lavara et al., 2011). However in that study, genetic correlation estimates were 
imprecise making it difficult to establish clear conclusions. The phenotypic results obtained in an experiment of divergent selection for body weight in rabbits showed that the high line had higher sperm concentration and less ejaculate volume than the low line, whereas no difference in male libido was encountered between them (Brun et al., 2006).

Estimates reported in pigs suggested that genetic correlations between growth and seminal traits such as ejaculate volume, sperm concentration, number of sperm produced, sperm motility and percentage of abnormal spermatozoa were negative, null or positive, but always had low magnitude (Oh et al., 2006a; Wolft, 2009).

The effects of selection for body weight in broilers on several semen characteristics such as sperm concentration, volume and motility were not consistent and they depended on the age of selection for growth (reviewed by: Rauw et al., 1998). This could probably be due to the negative correlations found between growth at different ages that are a consequence of the nonlinear pattern of growth (Barbato, 1999).

To our knowledge, there are no studies in rabbits analysing the relationship between the male contribution to fertility and prolificacy and growth. However, several studies involving rabbits (maternal lines selected by prolificacy traits) estimated the genetic correlation between growth and litter size of the female denoting that the observed genetic correlation was negative, null or positive but it had always low magnitude (Camacho and Baselga, 1990; Gomez et al., 1998; Garreau et al., 2000; García and Baselga, 2002a; Bünger et al., 2005). Tusell et al. (2009a) found a negative but low genetic correlation (-0.12) between average daily gain and female component of fertility (defined as success or failure to conception after $\mathrm{AI}$ ) in a rabbit paternal line. Therefore, in general, low genetic correlations have been encountered in the literature between growth traits and the female reproductive performance in rabbits.

In pigs, unfavourable genetic correlations were found for growth rate and several reproductive traits of the gilt such as the age at puberty, ability to show standing reflex, duration of standing oestrus but a positive genetic correlation was observed between growth rate and the intensity of vulvar symptoms (reviewed by: Rauw et al., 1998). Selection for lean growth has no effect on litter size whereas selection for high lean food conversion or low daily food intake caused a decreased effect on litter size (Kerr and Cameron, 1995; Chen et al., 2003).

In the poultry industry, selection for fast growth has resulted in detrimental effects on several reproductive traits. An excessive body weight in broiler breeder hens led to a reduced fertility. Accordingly, broilers selected for high body weight produced a higher number of eggs but a higher percentage of defective eggs. Selection for high body weight at 12 weeks and 8 weeks reduced the hatchability of fertile eggs and increased the frequency of chromosomal abnormalities (reviewed by: Rauw et al., 1998). 
Finally, Bünger et al. (2005) reviewed the genetic relationship between growth and prolificacy traits in several species such as fish, dogs, rabbits, sheep, pigs and mice. The author indicated that the genetic correlation between body weight and litter size in breeds of livestock species that have undergone selection is small and postulates that a positive correlation existed at the beginning of domestication but, as a consequence of the intense selection, this correlation has been reduced.

\subsection{Methods and models for the analyses of seminal traits and fertility}

\subsubsection{Genetic analysis of discrete traits}

Models for the analysis of binary traits are used in the context of this thesis for the analysis of fertility as well as for certain traits involved in the production of fertile doses of semen, such as the presence of certain residuals in the ejaculate and suitability for being used in AI of the ejaculate.

The threshold model was proposed by Wright (1934) for the analysis of categorical traits. This model postulates that a binary observed response is related to an underlying normally distributed variable, called liability (1), and to a fixed threshold that divides the continuous scale of 1 into to 2 intervals that delimit the 2 response categories. The extension to an arbitrary number of categories is relatively straightforward. Sorensen et al. (1995) applied data augmentation technique combined with Gibbs Sampling for the Bayesian analysis of categorical variables in an animal breeding context. The model describing $\mathbf{l}$ can be written as a Gaussian linear mixed model:

$\mathbf{I}=\mathbf{X} \boldsymbol{\beta}+\mathbf{Z} \mathbf{u}+\mathbf{e}$

The elements of $\mathbf{l}$ are assumed to be conditionally independent and distributed as follows:

$$
\mathbf{l} \mid \boldsymbol{\beta}, \mathbf{u} \sim N\left(\mathbf{X} \boldsymbol{\beta}+\mathbf{Z} \mathbf{u}, \mathbf{I} \sigma_{e}^{2}\right)
$$

Being I the identity matrix. As $\mathbf{I}$ is unobserved, to achieve identificability in the likelihood, when dealing with binary responses, both the threshold and the residual variance are usually constrained to 0 and 1 , respectively.

Binary observations are conditionally independent given the parameters of the model. Thus, the conditional distribution of data given the parameters can be written as follows (Sorensen et al., 1995): 


$$
p\left(\mathbf{y} \mid \boldsymbol{\beta}, \mathbf{u}, \mathbf{l}, \sigma_{u}^{2}\right)=\prod_{i=1}^{n}\left\{p\left(l_{i}>0\right) I\left(y_{i}=1\right)+p\left(l_{i} \leq 0\right) I\left(y_{i}=0\right)\right\}
$$

Where $\mathbf{y}=\left[y_{i}\right] \quad(i=1,2, \ldots, n)$ denotes the vector of observations and $I\left(y_{i}=j\right)$ is an indicator function that takes the value of 1 if the response belongs to the $j$ th category $(j=0,1)$ and 0 otherwise. The easiest Gibbs Sampler implementation requires augmenting the joint posterior distribution with the unobserved $\mathbf{l}$, then fully conditional posterior distributions of all parameters will have standard forms easy to sample from.

A linear approximation could be used for the analyses of a binary trait and several authors have concluded that threshold models tend to give larger parameter estimates than the linear ones (Boichard and Manfredi, 1994; Weigel and Rekaya, 2000). However, the main problem associated to the application of the threshold model methodology is the so-called extreme category problem (ECP). This could arise when there are only few observations per level of systematic effect and all the observations fall exclusively into one of the categories, the major consequence of this is that estimates would be biased.

In the specific case of fertility traits, male and female contributions to fertility have been, in general, separately analysed, but as the outcome of an AI event depends on both sexes, the two contributions to the final expression of AI outcome should be jointly analysed.

The additive and the product threshold models are two different approaches for the analysis of fertility defined as a binary trait. Both types of models allow estimating the genetic correlation between male and female contributions to fertility.

The additive threshold model proposes that the underlying variable of fertility is the result of the sum of genetic and environmental effects of the two individuals involved in the mating (Varona and Noguera, 2001; Piles et al., 2005). The conditional probability of a successful AI can be expressed as:

$$
p\left(\mathbf{y}=1 \mid \boldsymbol{\beta}_{m}, \boldsymbol{\beta}_{f}, \mathbf{u}_{m}, \mathbf{u}_{f}\right)=\Phi\left(\mathbf{X}_{m} \boldsymbol{\beta}_{m}+\mathbf{X}_{f} \boldsymbol{\beta}_{f}+\mathbf{Z}_{m} \mathbf{u}_{m}+\mathbf{Z}_{f} \mathbf{u}_{f}\right)
$$

Where $\mathbf{y}$ is the vector of the binary observations, $\Phi($.$) is the standard cumulative distribution$ function of the normal distribution. Terms $\boldsymbol{\beta}_{m}$ and $\boldsymbol{\beta}_{f}$ are vectors of systematic effects related to mating male and female, respectively; and $\mathbf{u}_{m}$ and $\mathbf{u}_{f}$ are vectors of male and female additive genetic effects, respectively. Finally, $\mathbf{X}_{m}, \mathbf{X}_{f}, \mathbf{Z}_{m}$ and $\mathbf{Z}_{f}$ are incidence matrices relating data to the corresponding systematic and additive genetic effects. For simplicity only male and female additive genetic effects are considered in the model above but other random effects could be included. 
David et al. (2009) proposed the product threshold model as another approach for the analysis of binary AI results. This model postulates that male and female contributions to a fertility outcome may not be purely additive. This model assumes that an observed reproduction outcome is the result of the product of two unobserved variables corresponding to the fertility of the two individuals involved in the mating. This approach could better reflect the biology of the fertility trait than the additive model. Within the product model a success in AI can only be achieved when both members of the mating are fertile, whereas with the additive model it would be possible to fit a successful mating of a highly fertile female, that makes liability to exceed the fertility threshold, with an infertile male, or vice versa.

Hence, following similar notation as for the additive threshold model, under the product threshold model, the conditional probability of an AI success resulting from the contributions of both sexes is expressed as the product of the probabilities of success of the 2 binary unobserved phenotypes corresponding to male and female contribution to fertility:

$$
p\left(\mathbf{y}=1 \mid \boldsymbol{\beta}_{m}, \boldsymbol{\beta}_{f}, \mathbf{u}_{m}, \mathbf{u}_{f}\right)=\Phi\left(\mathbf{X}_{m} \boldsymbol{\beta}_{m}+\mathbf{Z}_{m} \mathbf{u}_{m}\right) \times \Phi\left(\mathbf{X}_{f} \boldsymbol{\beta}_{f}+\mathbf{Z}_{f} \mathbf{u}_{f}\right)
$$

When fitting the product threshold model it is implicit that the observed AI result is the result of two conditionally independent events, i.e., male and female unobserved phenotypes (David et al., 2009). Conditional independence assumption does not allow estimating the effect of possible interactions between male and female components, or the contribution to fertility of the embryo. Biological interpretation of $\mathrm{h}^{2}$ obtained with the product threshold model is not straightforward and cannot be compared to the one obtained under an additive threshold approach. However, the product threshold model allows extracting more information from the data than the additive threshold model because it provides different estimates of the effect of factors affecting each unobserved phenotype as well as obtaining the probabilities of fertility success for each sex, which allows evaluating which sex is strongest responsible for an AI failure.

In their study, David et al. (2009) developed a Gibbs sampling algorithm for fitting the product threshold model under a Bayesian approach. They concluded that the product threshold model was able to provide good parameter estimates using data simulated under a product threshold model whereas, under the same scenario of data generation, the additive threshold model provided biased estimates. Performance of the product and the additive threshold model, in terms of predicting ability, was compared using real data coming from 3 livestock species: sheep, cattle and rabbits (David et al., 2011). The results obtained from this work concerning rabbits are discussed in this thesis.

Threshold model methodology can also be used for the analyses of other measurements of fertility such as number of inseminations to conception in which the number of AI occurs in a 
sequential order (i.e., an observation of a certain value of the trait requires to have passed through all previous stages). The ordinal threshold model (Gianola, 1982; Gianola and Foulley, 1983) assumes that the several sequential categories of response are the result of the hypothetical existence of several ordered thresholds in the liability. An alternative approach for the analyses of these type of traits is the sequential threshold model (Albert and Chib, 2001 ) in which the liability represents the individual ability to pass from one stage to the next. Hence, one stage can only be reached after passing the previous ones and, once the stage is reached; either a success or a failure to $\mathrm{AI}$ is observed. This approach has the advantage that it allows including specific factors affecting each stage (e.g. specific effects for each IA).

Another characteristic of number of inseminations to conception as well as other fertility traits is the presence of censored records (e.g. records from females that have been culled after AI, thus they did not have the chance for expressing the trait of interest). However, the assumption of noninformative censoring is not probably correct in most of the data, because females are commonly culled after several unsuccessful matings. Therefore, unexpected results and misleading interpretation can follow (Kalbfleisch and Prentice, 1980). GonzálezRecio et al. (2005) adapted three methods to deal with the presence of censored records on the number of inseminations to conception in dairy cows. First, they extended the ordinal threshold model to accommodate the analysis of censored records of this trait. The ordinal censored threshold model uses a method consisting in augmenting the data by sampling from a left truncated distribution every time that a censored record falls into to one of possible known categories. In that specific case, the truncation point was the threshold corresponding to the last observed insemination of the particular animal. The sequential threshold model was also adapted for these authors for taking into account censored records. Finally, another approach to handle censored records of a sequential trait is to use a particular type of proportional hazard models, the grouped survival model (Prentice and Gloeckler, 1978). This approach treats the number of inseminations to conception as time periods until an event of interest, which is calving. In the absence of calving, a censored record in the last insemination is assumed. This model defines the probability of having a pregnancy given that the cow was inseminated at a certain time period. González-Recio et al. (2005) compared the three approaches in terms of prediction ability of the models and concluded that the sequential threshold model had better predictive ability at the first insemination than the other two but the predictive ability in subsequent AIs was better for the censored threshold model. 


\subsubsection{Models for the analysis of longitudinal data}

One of the main characteristics of seminal and fertility traits data is that several records on the same animal can be measured over a period of time.

Several records from one individual are expected to show more resemblance among them than with other records from other individuals, not only because of common additive genetic effects but also because they will be affected by common non-additive genetic effects and permanent environmental effects. Therefore, repeated records on the same animal are generally higher correlated than two measurements on different animals. Also the correlation between repeated measurements is also expected to decreases as the time between measures increases (van der Werf, 2001).

Different models to analyse these longitudinal data taking into account these characteristics have been proposed in animal breeding.

The repeatability model assumes that different measurements on the same individual have the same genetic determinism and therefore are assumed to be repetitions of the same genetic trait. In this model the higher resemblance among records of the same individual is accounted for by including an individual permanent environmental effect. This model does not take into account in which order of time the records have been measured as it assumes that the correlation between records of the same individual is constant irrespectively of the time elapsed among measurements. Repeated records models are frequently used for the analysis of seminal quality and production traits (Basso et al., 2005) as well as for the analyses of reproductive performance traits (Piles et al., 2006).

Usage of a multiple trait model could be an alternative to the repeatability model when exist evidences indicating that measurements of the trait taken at different time do not have the same genetic basis and therefore it is preferable to consider them as different, but probably correlated traits. Multiple traits models have been widely used for the analyses of cow and heifer fertility traits (Jansen et al., 1987; Thaller, 1998). Litter size traits of different parities have also been analysed with multiple trait models in pigs (Noguera et al., 2002) and rabbits (Piles et al., 2006).

Under the multiple trait model approach, mixed model equations will be expanded and the number of parameters to be estimated will highly increased compared to single trait repeatability analyses, which could lead to computational problems (Strandberg and Malmfors, 2006). On the other hand, obtaining reliable and precise estimates of the correlations of the random effects is not straightforward, especially for the genetic correlation which, for a good estimation, requires from large amount of data with good connectivity 
among traits. Finally, a multiple trait model does not impose any longitudinal trajectory to the measurements, thus covariance structure is always left free and it could be possible to obtain weird results if some level of time is not properly represented in the data (i.e., the correlation between records should be related to the time that lies between the measurements; van der Werf, 2001). In addition, for applying these models grouping of records for being considered different traits is needed, and this lead to a discontinuous treatment of time (Carabaño et al., 2007).

Measurements that are taken along a trajectory of time can be more appropriately modelled as a function of the parameters that define that trajectory. Knowledge of the function that describes how the trait changes along time can help in understanding the behaviour of the trait for making inferences about the expected trajectory. In addition, differences among individuals can exist in the trajectory patterns which could be exploited for genetic selection (Sorensen and Gianola, 2002). Some longitudinal models can incorporate heterogeneous (co)variances among measurements over time, requiring a reduced number of parameters to be estimated than that required under the multiple trait approach.

Random regression models (Henderson, 1982) attempt to model the age-dependent deviations from the population mean due to individual genetic and environmental factors. These models have been used for the analysis of the GxE (already been briefly described in the Reaction Norms models) as well as for the genetic evaluation of dairy cattle using test day records and growth curves in several livestock species (reviewed by: Meyer, 2001; Schaeffer, 2004). More recently, random regression models were used for the longitudinal analysis of sperm motility and ejaculate volume in bulls (Serrano et al., 2006; Carabaño et al., 2007), total number of sperm in boars (Oh et al., 2006b) and male and female contributions to fertility in chickens (Wolc et al., 2009). Another approach is the structured antedependence model (SAD; Jaffrezic et al., 2004) in which records at a given time are defined as a function of previous observations. On the other hand, character process (CP) attempts to model the covariance functions among measurements themselves. This model was used by David et al. (2007a) to analyse longitudinal data of semen volume in rams.

Finally, another approach consists in simultaneously estimating the parameters of the curve that describes the longitudinal trajectory of the trait for each animal and their variance components by using a hierarchical model under a Bayesian framework. This model, proposed by Wakefield et al. (1994b), has the advantage that curve parameters can have a biological interpretation and it has been already briefly described in "Models for the analyses of GxE" section. 


\subsubsection{Models for the joint analysis of seminal and reproductive performance traits}

The joint analyses of seminal traits and male reproductive performance can be done by the usage of multiple trait models or some extension of them, which are the recursive models. The interest in using this last approach is that these models allow considering the effect of seminal traits on the phenotypic expression of fertility but they also take into account that seminal traits in turn, also have genetic and permanent effects contributing to their phenotypic expression.

A recursive multi-trait model is a particular case of a structural equation model, which Gianola and Sorensen (2004) introduced to the field of quantitative genetics. These models are useful for describing biological relationships between traits. For a pair of traits simultaneity or recursiveness, are two types of relationships. The first one indicates that changes in one trait affect a second trait and, in turn, the second trait affects the first trait. The second one refers to a situation where one trait affects the other but the last does not affect the first one. These authors also pointed out that, in the presence of these relationships, if they are not properly taken into account, biased (co)variance estimates can be obtained. After the publication of the aforementioned study several authors have been using these models for describing biological relationships between several types of traits in livestock species (de los Campos et al., 2006; López de Maturana et al., 2007; Varona et al., 2007; Wu et al., 2008). To our knowledge, there are no studies in the literature using recursive models to analyse the relationship between seminal traits and male reproductive performance.

\subsection{Literature cited}

A.-Ranberg, I. M., B. Heringstad, G. Klemetsdal, M. Svendsen, and T. Steine. 2003. Heifer fertility in Norwegian dairy cattle: Variance components and genetic change. J. Dairy Sci. 86:27062714.

Adamec, V., and R. K. Johnson. 1997. Genetic analysis of rebreeding intervals, litter traits, and production traits in sows of the national Czech nucleus. Livest. Prod. Sci. 48:13-22.

Adams, C. E., and M. M. Singh. 1981. Semen characteristics and fertility of rabbits subjected to exhaustive use. Lab. Anim. 15:157-161.

Al-Katanani, Y. M., D. W. Webb, and P. J. Hansen. 1999. Factors affecting seasonal variation in 90-day nonreturn rate to first service in lactating Holstein cows in a hot climate. J. Dairy Sci. 82:2611-2616.

Albert, J. H., and S. Chib. 2001. Sequential ordinal modelling with applications to survival data. Biometrics 57:829-836. 
Alm, K., J. Taponen, M. Dahlbom, E. Tuunainen, E. Koskinen, and M. Andersson. 2001. A novel automated fluorometric assay to evaluate sperm viability and fertility in dairy bulls. Theriogenology 56:677-684.

Alvariño, J. M. R. 2000. Reproductive performance of male rabbits. Proc. 7th World Rabbit Congr., Valencia, Spain A:13-35.

Alvariño, J. M. R., F. J. López, J. A. Del Arco, R. Bueno, and R. Torres. 1996. Effects of semen concentration on rabbit artificial insemination with fresh or 24 hours stored semen. Proc. 6th World Rabbit Congr., Toulouse, France. 2:33-35.

Amann, R. P. 1989. Can the fertility potential of a seminal sample be predicted accurately? J. Androl. 10:89-98.

Amann, R. P., and R. H. Hammerstedt. 2002. Detection of differences in fertility - andrology lab corner. J. Androl. 23:317-325.

Ardón, F., D. Helms, E. Sahin, H. Bollwein, E. Topfer-Petersen, and D. Waberski. 2008. Chromatin-unstable boar spermatozoa have little chance of reaching oocytes in vivo. Reproduction 135:461-470.

Argov, N., U. Moallem, and D. Sklan. 2005. Summer heat stress alters the MRNa expression of selective-uptake and endocytotic receptors in bovine ovarian cells. Theriogenology 64:14751489.

Armero, E., and Blasco, A. 1992. Economic weights for rabbit selection indices. J. Appl. Rabbit Res. 15:637-642.

Arroita, Z., M. V. Falceto, S. Martin-Rillo, C. De Alba, C. Moreno, M. J. Ciudad, and O. Rafel. 2000a. Effect of collection frequency on production, quality and storage of young bucks semen. In Proc. 7th World Rabbit Congress. Valencia, Spain A:81-87.

Arroita, Z., M. V. Falceto, S. Martin-Rillo, C. De Alba, C. Moreno, M. J. Ciudad, and O. Rafel. 2000b. Effect of collection frequency on production, quality and storage of young bucks semen. 7 th World Rabbit Congress A:81-87.

Assumpção, T. I., R. A. A. Torres-Júnior, M. V. Sousa, and C. A. O. Ricart. 2005. Correlation between fertility and levels of protein, sugar and free amino acids in seminal plasma of Nelore bulls. Arq. Bras. Med. Vet. Zootec. 57:55-61.

Averill, T. A., R. Rekaya, and K. Weigel. 2004. Genetic analysis of male and female fertility using longitudinal binary data. J. Dairy Sci. 87:3947-3952.

Ayyat, M. S., I. F. M. Marai, and G. H. A. El-Sayiad. 1995. Genetic and non genetic factors affecting milk production and preweaning litter traits of New Zealand white does under Egyptian conditions. World Rabbit Sci. 3:119-124.

Ballachey, B. E., D. P. Evenson, and R. G. Saacke. 1988. The sperm chromatin structure assay. Relationship with alternate tests of semen quality and heterospermic performance of bulls. J. Androl. 9:109-115.

Bamba, K. 1988. Evaluation of acrosome integrity of boar spermatozoa by bright field microscopy using an eosin-nigrosin stain. Theriogenology 29:1245-1251.

Banks, S., S. A. King, D. S. Irvine, and P. T. K. Saunders. 2005. Impact of a mild scrotal heat stress on DNA integrity in murine spermatozoa. Reproduction 129:505-514.

Barbato, G. 1999. Genetic relationships between selection for growth and reproductive effectiveness. Poult. Sci. 78:444-452.

Barth, A. D., and R. J. Oko. 1989. Abnormal morphology of bovine spermatozoa. Ames, ia: Iowa state university press.

Baselga, M. 2004. Genetic improvement of meat rabbits. Programmes and diffusion. Proc. 8th World Rabbit Congr., Puebla, Mexico. 1:1-13. 
Baselga, M., M. L. Garcia, J. P. Sanchez, J. S. Vicente, and R. Lavara. 2002. Analysis of litter size traits in a three line diallel cross in rabbits. In Proc. $7^{\text {th }}$ World Congress on Genetics Applied to Livestock Production, Montpellier, France, August, 2002. Session 4:0-4.

Baselga, M., M. L. Garcia, J. P. Sanchez, J. C. Vicente, and R. Lavara. 2003. Analysis of reproductive traits in crosses among maternal lines of rabbits. Anim. Res. 52:473-479.

Basso, B., S. Fritz, T. Druet, F. Guillaume, M. N. Rossignil, Y. Amigues, R. Gabriel, E. S.-C. Sellem, L., and P. D. Humblot, X. 2005. Estimation de paramètres génétiques et détection de QTL liés à des caractères de fertilité mâle, de production de semence et de qualité de la semence chez le taureau laitier. In Proc. Rencontre Recherche Ruminants, 7-8 December 2005, Paris. pp. 145148.

Beletti, M. E. Ì. l., and M. L. S. Mello. 2004. Comparison between the toluidine blue stain and the feulgen reaction for evaluation of rabbit sperm chromatin condensation and their relationship with sperm morphology. Theriogenology 62:398-402.

Bencheikh, N. 1995. The effect of frequency of ejaculation on semen characteristics and sperm output in the rabbit. Ann. Zootech. 44:263-279.

Berger, T. 1998. Male effects on reproductive performance. J. Anim. Sci. 76:47-51.

Bishop, C. M. 1995. Neural networks for pattern recognition. Oxford University Press.

Blasco, A. 1996. Genetics of litter size and does fertility in the rabbit. In Proc. $6^{\text {th }}$ World Rabbit Congress. Toulouse. 2:219-227.

Boettcher, P. J., and J. Fatehi. 2003. Genotype x environment interactions in conventional versus pasture-based dairies in Canada. J. Dairy Sci. 83:383-389.

Bohmanova, J., I. Misztal, and J. B. Cole. 2007. Temperature-humidity indices as indicators of milk production losses due to heat stress. J. Dairy Sci. 90:1947-1956.

Boichard, D., and E. Manfredi. 1994. Genetic-analysis of conception rate in French Holstein cattle. Acta Agriculturae Scandinavica Section a-Animal Science 44:138-145.

Boiti, C., C. Castellini, M. Theau-clement, U. Besenfelder, L. Liguori, T. Renieri, and F. Pizzi. 2005. Guidelines for the handling of rabbit bucks and semen. World Rabbit Sci. 13:71-91.

Brandon, C. I., G. L. Heusner, A. B. Caudle, and R. A. Fayrer-Hosken. 1999. Two-dimensional polyacrylamide gel electrophoresis of equine seminal plasma proteins and their correlation with fertility. Theriogenology 52:863-873.

Braundmeier, A. G., J. M. Demers, R. D. Shanks, and D. J. Miller. 2004. The relationship of porcine sperm zona-binding ability to fertility. J. Anim. Sci. 82:452-458.

Braundmeier, A. G., and D. J. Miller. 2001. Invited review: The search is on: Finding accurate molecular markers of male fertility. J. Dairy Sci. 84:1915-1925.

Brun, J. M., A. Sanchez, R. Duzert, G. Saleil, and M. Theau-Clément. 2009. Paramètres génétiques des caractéristiques de la semence de lapin. 13èmes Journ. Rech. Cunicole, Le Mans, France. 11:17-18

Brun, J. M., M. Theau-Clement, and G. Bolet. 2002a. Evidence for heterosis and maternal effects on rabbit semen characteristics. Anim. Res. 51:433-442.

Brun, J. M., M. Theau-Clement, and G. Bolet. 2002b. The relationship between rabbit semen characteristics and reproductive performance after artificial insemination. Anim. Reprod. Sci. 70:139-149.

Brun, J. M., M. Theau-Clément, J. Esparbié, J. Falières, G. Saleil, and C. Larzul. 2006. Semen production in two rabbit lines divergently selected for 63-d body weight. Theriogenology 66:2165-2172. 
Buchanan, D. S. 1987. The crossbred sire: Experimental results for swine. J. Anim Sci. 65: 117127.

Bünger, L., R. M. Lewis, M. F. Rothschild, A. Blasco, U. Renne, and G. Simm. 2005. Relationships between quantitative and reproductive fitness traits in animals. Phil. Trans. R. Soc. B. 360:1489-1502.

Camacho, J., and M. Baselga. 1990. Genetic correlation between reproductive and growth traits in rabbits. In Proc: 4th World Congress on Genetics Applied to the Livestock Production, Edinburgh, Scotland 16:366-369.

Cancel, A. M., D. Lobdell, P. Mendola, and S. D. Perreault. 2000. Objective evaluation of hyperactivated motility in rat spermatozoa using computer-assisted sperm analysis. Hum. Reprod. 15: 1322-1328.

Carabaño, M. J., C. Díaz, C. Ugarte, and M. Serrano. 2007. Exploring the use of random regression models with Legendre polynomials to analyze measures of volume of ejaculate in Holstein bulls. J. Dairy Sci. 90:1044-1057.

Carabaño, M. J., K. M. Wade, and L. D. Van Vleck. 1990. Genotype by environment interactions for milk and fat production across regions of the United States. J. Dairy Sci. 73:173-180.

Casey, P. J., R. B. Hillman, K. R. Robertson, A. I. Yudin, I. K. Liu, and E. Z. Drobnis. 1993. Validation of an acrosomal stain for equine sperm that differentiates between living and dead sperm. J. Androl. 14:289-297.

Castellini, C. 2008. Semen production and management of rabbit bucks. In Proc. 9th World Rabbit Congress.Verona, Italy.

Castellini, C., and P. Lattaioli. 1999. Effect of number of motile sperms inseminated on reproductive performance of rabbit does. Anim. Reprod. Sci. 57:111-120.

Castellini, C., P. Lattaioli, R. Cardinali, and A. Dal Bosco. 2006. Effect of collection rhythm on spermatozoa and droplet concentration of rabbit semen World Rabbit Sci. 14:101-106.

Castellini, C., P. Lattaioli, R. Cardinali, A. Dal Bosco, and E. Mourvaki. 2007. Validation of a spectrophometric method used for the measurement of spermatozoa concentration in rabbit semen 15:115-119.

Castellini, C., P. Lattaioli, M. Moroni, and A. Minelli. 2000. Effect of seminal plasma on the characteristics and fertility of rabbit spermatozoa. Anim. Reprod. Sci. 63:275-282.

Chen, P., T. J. Baas, J. W. Mabry, and K. J. Koehler. 2003. Genetic correlations between lean growth and litter traits in U.S. Yorkshire, Duroc, Hampshire, and Landrace pigs. J. Anim Sci. 81:1700-1705.

Cheng, H., M. P. Dooley, S. M. Hopkins, L. L. Anderson, S. Yibchok-anun, and W. H. Hsu. 1999. Development of rabbit embryos during a 96-h period of in vitro culture after superovulatory treatment under conditions of elevated ambient temperature. Anim. Reprod. Sci. 56:279-290.

Christensen, P., D. Boelling, K. M. Pedersen, I. R. Korsgaard, and J. Jensen. 2005. Relationship between sperm viability as determined by flow cytometry and nonreturn rate of dairy bulls. J. Androl. 26:98-106.

Clay, J. S., and B. T. McDaniel. 2001. Computing mating bull fertility from DHI nonreturn data. J. Dairy Sci. 84:1238-1245.

Coffey, D. S. 1988. Androgen action and the sex accessory tissues. In: Physiology of reproduction, knobill. E., neill, j.D. (eds.), raven press, new york, pp. 1081-119.

Colenbrander, B., B. M. Gadella, and T. A. E. Stout. 2003. The predictive value of semen analysis in the evaluation of stallion fertility. Reproduction in Domestic Animals 38:305-311. 
Correa, J. R., M. M. Pace, and P. M. Zavos. 1997. Relationships among frozen-thawed sperm characteristics assessed via the routine semen analysis, sperm functional tests and fertility of bulls in an artificial insemination program. Theriogenology 48:721-731.

Courtens, J. L., G. Bolet, and M. Theauclement. 1994. Effect of acrosome defects and sperm chromatin decondensation on fertility and litter size in the rabbit - preliminary electronmicroscopic study. Reprod. Nutr. Dev. 34: 427-437.

Cross, N. L., P. Morales, J. W. Overstreet, and F. W. Hanson. 1986. Two simple methods for detecting acrosome-reacted human sperm. Gamete Res. 15:213-226.

D'Occhio, M. J., K. J. Hengstberger, and S. D. Johnston. 2007. Biology of sperm chromatin structure and relationship to male fertility and embryonic survival. Anim. Reprod. Sci. 101:117.

David, I., L. Bodin, D. Gianola, A. Legarra, E. Manfredi, and C. Robert-Granié. 2009. Product versus additive threshold models for analysis of reproduction outcomes in animal genetics. J. Anim. Sci. 87:2510-2518.

David, I., L. Bodin, G. Lagriffoul, E. Manfredi, and C. l. Robert-Granié. 2007a. Character process model for semen volume in AI rams: Evaluation of correlation structures for long and shortterm environmental effects. Genet. Sel. Evol. 39:55-71.

David, I., M. J. Carabano, L. Tusell, C. Diaz, O. Gonzalez-Recio, E. Lopez de Maturana, M. Piles, E. Ugarte, and L. Bodin. 2011. Product versus additive model for studying artificial insemination results in several livestock populations. J. Anim Sci. 89:321-328.

David, I., X. Druart, G. Lagriffoul, E. Manfredi, C. l. Robert-Granié, and L. Bodin. 2007b. Genetic and environmental effects on semen traits in lacaune and manech tête rousse ai rams. Genet. Sel. Evol. 39: 405-419.

De Rochambeau, H., L. de la Fuente, F., R. Rouvier, and J. Ouhayoun. 1989. Sélection sur la vitesse de croissance post-sevrage chez le lapin. Genet. Sel. Evol. 21:527-546.

DeJarnette, J. M., C. E. Marshall, R. W. Lenz, D. R. Monke, W. H. Ayars, and C. G. Sattler. 2004. Sustaining the fertility of artificially inseminated dairy cattle: The role of the artificial insemination industry. J. Dairy Sci. 87:E93-104.

Den Daas, J. H. G., G. De Jong, L. Lansbergen, and A. M. Van Wagtendonk-De Leeuw. 1998. The relationship between the number of spermatozoa inseminated and the reproductive efficiency of individual dairy bulls. J. Dairy Sci. 81:1714-1723.

Desjardins, C., K. T. Kirton, and H. D. Hafs. 1968. Sperm output of rabbits at various ejaculation frequencies and their use in the design of experiments. J. Reprod. Fert. 15:27-32.

Doney, J. M., R. G. Gunn, and J. G. Griffiths. 1973. The effect of premating stress on the onset of oestrus and on ovulation rate in Scottish blackface ewes. J. Reprod. Fertil. 35:381-384.

Ducrocq, V., and P. Humblot. 1995. Genetic characteristics and evolution of semen production of young normande bulls. Livestock Production Science 41:1-10.

Ealy, A. D., M. Drost, and P. J. Hansen. 1993. Developmental changes in embryonic resistance to adverse effects of maternal heat stress in cows. J. Dairy Sci. 76:2899-2905.

Enciso, M., L. Muriel, J. L. Fernandez, V. Goyanes, E. Segrelles, M. Marcos, J. M. Montejo, M. Ardoy, A. Pacheco, and J. Gosalvez. 2006. Infertile men with varicocele show a high relative proportion of sperm cells with intense nuclear damage level, evidenced by the sperm chromatin dispersion test. J. Androl. 27:106-111.

ESHRE-SIGA, N. a. 2002. Manual on basic semen analysis. Available on line: http://www.nafa.nu/manual2002.pdf.

Estany, J., J. Camacho, M. Baselga, and A. Blasco. 1992. Selection response of growth rate in rabbits for meat production. Genet. Sel. Evol. 24:527-537. 
Evenson, D. P., L. Thompson, and L. Jost. 1994. Flow cytometric evaluation of boar semen by the sperm chromatin structure assay as related to cryopreservation and fertility. Theriogenology 41:637-651.

Evenson, D. P., and R. Wixon. 2006. Clinical aspects of sperm DNA fragmentation detection and male infertility. Theriogenology 65:979-991.

Falconer, D. S. 1952. The problem of environment and selection. Am. Nat. 86:293-298.

Falconer, D. S., and T. F. C. MacKay. 1996. Introduction to quantitative genetics 4th edition. Longman Scientific \& Technical, Burnt Mill, Harlow, United Kingdom.

FAO. 2001. Fao recognizes the increasingly important role of rabbit breeding. Press release 01/57. Available on line at:

Http://www.Fao.Org/waicent/ois/press_ne/presseng/2001/pren0157.Htm.

FAO. 2006. Livestock report. Available online at:

Ftp://ftp.Fao.Org/docrep/fao/009/a0255e/a0255e.Pdf.

Farrell, B. P., R. H. Foote, M. E. Simkin, E. D. Clegg, and R. J. Wall. 1993. Relationship of semen quality, number of sperm inseminated, and fertility in rabbits. J. Androl. 14:464-471.

Farrell, P. B., G. A. Presicce, C. C. Brockett, and R. H. Foote. 1998. Quantification of bull sperm characteristics measured by computer-assisted sperm analysis (CASA) and the relationship to fertility. Theriogenology 49:871-879.

Fernández-Carmona, J., C. Cervera, and J. J. Pascual. 1997. Parámetros productivos de conejas a tres temperaturas ambientales. In: Proc. XXII Symposium de Cunicultura. Las Palmas de Gran Canarias, Spain.

Fernández-Carmona, J., C. Cervera, C. Sabater, and E. Blas. 1995. Effect of diet composition on the production of rabbit breeding does housed in a traditional building and at $30^{\circ} \mathrm{c}$. Anim. Feed Sci. Technol. 52:289-297.

Fikse, W. F., R. Rekaya, and K. A. Weigel. 2003. Genotype x environment interaction for milk production in Guernsey cattle. J. Dairy Sci. 86:1821-1827.

Finzi, A., P. Morera, and G. Kuzminsky. 1995. Sperm abnormalities as possible indicators of rabbit chronic heat stress. World Rabbit Sci. 3:157-161.

Flowers, W. L. 1997. Management of boars for efficient semen production. J. Reprod. Fertil. 52:67-78.

Flowers, W. L. 2008. Genetic and phenotypic variation in reproductive traits of AI boars. Theriogenology 70:1297-1303.

Foote, R. H. 2003. Fertility estimation: A review of past experience and future prospects. Anim. Reprod. Sci. 75:119-139.

Fortun, F., and G. Bolet. 1995. Les effets de la lactation sur les performances de reproduction chez le lapine. INRA Prod. Anim. 8:49-56.

Francavilla, F., R. Santucci, B. Macerola, G. Ruvolo, and R. Romano. 2000. Nitric oxide synthase inhibition in human sperm affects sperm-oocyte fusion but not zona pellucida binding. Biol. Reprod. 63:425-429.

Furstoss, V., I. David, B. Leboeuf, P. Guillouet, P. Boue, and L. Bodin. 2009. Genetic and nongenetic parameters of several characteristics of production and semen quality in young bucks. Anim. Reprod. Sci. 110:25-36.

Gadea, J. 2005. Sperm factors related to in vitro and in vivo porcine fertility. Theriogenology 63:431-444.

Gadea, J., E. Selles, and M. A. Marco. 2004. The predictive value of porcine seminal parameters on fertility outcome under commercial conditions. Reprod. Dom. Anim. 39:303-308. 
García-Ispierto, I., F. López-Gatius, G. Bech-Sabat, P. Santolaria, J. L. Yániz, C. Nogareda, F. De Rensis, and M. López-Béjar. 2007. Climate factors affecting conception rate of high producing dairy cows in northeastern Spain. Theriogenology 67:1379-1385.

García-Macías, V., P. De Paz, F. Martinez-Pastor, M. Álvarez, S. Gomes-Alves, J. Bernardo, E. Anel, and L. Anel. 2007. DNA fragmentation assessment by flow cytometry and sperm-bosHalomax (bright-field microscopy and fluorescence microscopy) in bull sperm. Int. J. Androl. 30:88-98.

Garcia-Tomás, M. 2006. Estudi de la millora en lús de mascles d'inseminació artificial en conills. Phd diss., Universitat de Barcelona, Barcelona.

García-Tomás, M., J. Sánchez, and M. Piles. 2009. Post-natal sexual development of testis and epididymis in the rabbit: Variability and relationships among macroscopic and microscopic markers. Anim. Reprod. Sci. 110:347-355.

Garcia-Tomás, M., J. Sanchez, O. Rafel, J. Ramon, and M. Piles. 2006a. Reproductive performance of crossbred and purebred male rabbits. Livest. Sci. 104:233-243.

Garcia-Tomás, M., J. Sanchez, O. Rafel, J. Ramon, and M. Piles. 2006b. Variability, repeatability and phenotypic relationships of several characteristics of production and semen quality in rabbit. Anim. Reprod. Sci. 93:88-100.

Garcia-Tomás, M., J. Sanchez, O. Rafel, J. Ramon, and M. Plies. 2006c. Heterosis, direct and maternal genetic effects on semen quality traits of rabbits. Livestock Science 100:111-120.

Garcia-Tomas, M., L. Tusell, M. López-Béjar, J. Ramon, O. Rafel, and M. Piles. 2008. Influence of environmental temperature and relative humidity on quantitative and qualitative semen traits in rabbits. Proc. 9th World Rabbit Congr. Verona, Italy. 72:111.

García, M. L., and M. Baselga. 2002a. Estimation of correlated response on growth traits to selection in litter size of rabbits using a cryopreserved control population and genetic trends. Livestock Production Science 78:91-98.

García, M. L., and M. Baselga. 2002b. Estimation of genetic response to selection in litter size of rabbits using a cryopreserved control population. Livest. Prod. Sci. 74:45-53.

Garreau, H., Z. S. Szendro, C. Larzul, and H. Rochambeau. 2000. Genetic parameters and genetic trends of growth and litter size traits in the white Pannon breed. In Proc. 7th World Rabbit Congress, Valencia, Spain.

Gianola, D. 1982. Theory and analysis of threshold characters. J. Anim Sci. 54: 1079-1096.

Gianola, D., and J. Foulley, L. 1983. Sire evaluation for ordered categorical data with a threshold model. Genet. Sel. Evol. 15:201-224.

Gianola, D., and D. Sorensen. 2004. Quantitative genetic models for describing simultaneous and recursive relationships between phenotypes. Genetics 167:1407-1424.

Gómez, E. 2006. Producción industrial de gazapos: Algunos puntos críticos. Main components affecting productivity in rabbit breeding XXXI Simposium de Cunicultura, Lorca, Spain.

Gomez, E. A., O. Rafel, J. Ramon, and 552-555. 1998. Genetic relationships between growth and litter size traits at first parity in a specialized dam line. In Proc. 6th World Congress on Genetics Applied to Livestock Production, Armidale, Australia. 25.

González-Recio, 0. 2006. Selection for female fertility in spanish dairy cattle. Phd diss, Escuela Técnica de Ingenieros Agrónomos. Universidad Politécnica de Madrid, Madrid.

González-Recio, O., Y. M. Chang, D. Gianola, and K. A. Weigel. 2005. Number of inseminations to conception in Holstein cows using censored records and time-dependent covariates. J. Dairy Sci. 88:3655-3662.

Gravance, C. G., and R. O. Davis. 1995. Automated sperm morphometry analysis (ASMA) in the rabbit. J. Androl. 16:88-93. 
Gravance, C. G., I. K. M. Liu, R. O. Davis, J. P. Hughes, and P. J. Casey. 1996. Quantification of normal head morphometry of stallion spermatozoa. J. Reprod. Fertil. 108:41-46.

Gregoire, A. T., R. W. Bratton, and R. H. Foote. 1958. Sperm output and fertility of rabbits ejaculated either once a week or once a day for forty-three weeks. J. Anim Sci. 17:243-248.

Hagen, D. R., A. L. Gilkey, and R. H. Foote. 2002. Spermatozoal velocity and motility and its relationship to fertility in the rabbit inseminated with low sperm numbers. 10:135-140.

Hamann, H., R. Steinheuer, and O. Distl. 2004. Estimation of genetic parameters for litter size as a sow and boar trait in German herdbook Landrace and Pietrain swine. Livest. Prod. Sci. 85:201-207.

Hanenberg, E. H. A. T., E. F. Knol, and J. W. M. Merks. 2001. Estimates of genetic parameters for reproduction traits at different parities in Dutch Landrace pigs. Livestock Production Science 69:179-186.

Hansen, P. J. 2009. Effects of heat stress on mammalian reproduction. Phil. Trans. R. Soc. B. 364:3341-3350.

Hansen, P. J., M. Drost, R. M. Rivera, F. F. Paula-Lopes, Y. M. Al-Katanani, C. E. Krininger, and C. C. Chase. 2001. Adverse impact of heat stress on embryo production: Causes and strategies for mitigation. Theriogenology. 55:91-103.

Harkness, J. E. 1988. Rabbit behaviour as related to environmental stress. J. Appl. Rabbit Res. $11: 227-236$

Haugan, T., Y. T. Gröhn, E. Kommisrud, E. Ropstad, and O. Reksen. 2007. Effects of sperm concentration at semen collection and storage period of frozen semen on dairy cow conception. Anim. Reprod. Sci. 97:1-11.

Henderson, C. R. J. 1982. Analysis of covariance in the mixed model: Higher-level, nonhomogeneous, and random regressions Biometrics 38:623-640.

Holm, B., M. Bakken, O. Vangen, and R. Rekaya. 2005. Genetic analysis of age at first service, return rate, litter size, and weaning-to-first service interval of gilts and sows. J. Anim. Sci. 83:41-48.

Howarth, B., Jr, C. W. Alliston, and L. C. Ulberg. 1965. Importance of uterine environment on rabbit sperm prior to fertilization. J. Anim Sci. 24:1027-1032.

Hulet, C. V., and S. K. Ercanbrack. 1962. A fertility index for rams. J. Anim Sci. 21:489-493.

Iraqi, M. M., M. E. Shenana, and M. Baselga. 2007. Some factors affecting production and milk composition characters in a crossbreeding experiment involving Gabali and V-line rabbits in Egypt. World Rabbit Sci. 15:151-159.

ITAVI. 2007. Reseau de fermes de references cunicoles. Programme cunimieux. Comité de pilotage de 11 de juin 2007. Available on line at: http://www.Itavi.Asso.Fr.

ITAVI. 2008. Gestion technico-économique des éleveurs de lapins de chair (programmes renaceb et renalap) résultats 2008. Comité de pilotage de 10 de septembre 2009. Available on line at: http://www.Itavi.Asso.Fr/economie/references/lapins.Php.

Jaffrezic, F., E. Venot, D. Laloe, A. Vinet, and G. Renand. 2004. Use of structured antedependence models for the genetic analysis of growth curves. J. Anim Sci. 82:3465-3473.

Jansen, J., J. van der Werf, and W. de Boer. 1987. Genetic relationships between fertility traits for dairy cows in different parities. Livest. Prod. Sci. 17:337-349.

Jordan, E. R. 2003. Effects of heat stress on reproduction. J. Dairy Sci. 86:E104-E114.

Kalbfleisch, J. D., and R. L. Prentice. 1980. The statistical analysis of failure time data. John Willey and Sons, New York, USA. 
Karoui, S., C. Díaz, M. Serrano, R. Cue, I. Celorrio, and M. J. Carabaño. 2011. Time trends, environmental factors and genetic basis of semen traits collected in holstein bulls under commercial conditions. Anim. Reprod. Sci. 124:28-38.

Kearney, J. F., S. M.M., and P. J. Boettcher. 2004. Genotype x environment interaction for grazing vs. confinement. II. Health and reproduction traits. J. Dairy Sci. 87:510-516.

Keel, B. A., and T. K. Schaule. 2000. Correlation of the bovine cervical mucus penetration test with human sperm characteristics 1406 ejaculates. Arch. Andrology. 44:109-115.

Kerr, J. C., and N. D. Cameron. 1995. Reproductive performance of pigs selected for components of efficient lean growth. Anim. Sci. 60:281-290.

Khalil, M. H., K. A. Al-Sobayil, A. M. Al-Saef, M. L. García, and M. Baselga. 2007. Genetic evaluation for semen characteristics in a crossbreeding project involving Saudi and Spanish Vline rabbits. Animal 1:923-928.

Killian, G. J., D. A. Chapman, and L. A. Rogowski. 1993. Fertility-associated proteins in Holstein bull seminal plasma. Biol. Reprod. 49:1202-1207.

Kirkpatrick, M., and D. Lofsvold. 1989. The evolution of growth trajectories and other complex quantitative characters. Genome 31:778-783.

Kolmodin, R. 2003. Reaction norms for the study of genotype by environment interaction in animal breeding. Phd diss. Dept. of animal breeding and genetics. Swedish univ. of agricultural sciences. Uppsala.

Kolmodin, R., E. Strandberg, H. Jorjani, and B. Danell. 2003. Selection in presence of a genotype by environment interaction: Response in environmental sensitivity. Anim. Sci. 76:375-385.

Kolmodin, R., E. Strandberg, P. Madsen, J. Jensen, and H. Jorjani. 2002. Genotype by environment interaction in nordic dairy cattle studied using reaction norms. Acta Agric. Scand., Section A, Anim. Sci. 52:11-24.

Koops, W. J., M. Grossman, and J. H. G. den Daas. 1995. A model for reproductive efficiency in dairy bulls. J. Dairy Sci.: 921-928.

Kuhn, M. T., and J. L. Hutchison. 2008. Prediction of dairy bull fertility from field data: Use of multiple services and identification and utilization of factors affecting bull fertility. J. Dairy Sci. 91:2481-2492.

Kuzminsky, G., A. M. Fausto, and P. Morera. 1996. Morphological abnormalities of rabbit spermatozoa studied by scanning electron microscope and quantified by light microscope. Reprod. Nutr. Dev. 36:565-575.

Larzul, C., F. Gondret, S. Combes, H. Garreau, and H. Rochambeau. 2003. Analyse d'une expérience de sélection sur le poids à 63 jours :I - déterminisme génétique de la croissance. 10èmes Journ. Rech. Cunicole, Paris, France.: 149-152.

Lavara, R., M. L. García, C. Torres, J. C. Vicente, and M. Baselga. 2008a. Genetic parameters for semen traits of rabbit males: I. Production, morphology, and sperm head morphometry. In Proc. 9th World Rabbit Congress.Verona, Italy. 72:58-58.

Lavara, R., M. L. García, C. Torres, J. C. Vicente, and M. Baselga. 2008b. Genetic parameters for semen traits of rabbit males: Ii. Motility. In Proc. 9th World Rabbit Congress. Verona, Italy. 72:59-59.

Lavara, R., E. Moce, F. Lavara, M. P. V. de Castro, and J. S. Vicente. 2005. Do parameters of seminal quality correlate with the results of on-farm inseminations in rabbits? Theriogenology 64:1130-1141.

Lavara, R., J. S. Vicente, and M. Baselga. 2011. Genetic parameter estimates for semen production traits and growth rate of a paternal rabbit line. J. Anim. Breed. Genet. 128:44-51. 
Lebas, F. 1997. The rabbit: Husbandry, health and production (new revised version). Available on line at: http://www.Fao.Org/docrep/t1690e/t1690e00.Htm\#contents. FAO Animal Production and Health Series 21.

Legault, C., F. Menissier, P. Merat, G. Rilcordeau, and R. Rouvier. 1996. X. INRA Prod. Anim. Hors série, 41-56.

López, F. J., J. M. R. Alvariño, J. A. Del Arco, F. Delgado, and J. L. Ramiro. 1996. Effect of cooling temperature on 24 hours stored semen for artificial insemination. In Proc. $6^{\text {th }}$ World Rabbit Congress, Toulouse, France. 2:79-81.

Lopez, J., J. M. R. Alvariño, J. A. Del Arco, A. Bueno, and C. Sanz. 1996. Effect of male rabbit management on semen porduction. In Proc. 6th World Rabbit Congress. Toulouse. 1996 2:8386.

LPHSI. 1990. Livestock and poultry heat stress indices, agriculture engineering technology guide, clemson university, clemson, SC (1990).

Lukefahr, S. D., and H. H. Hamilton. 1997. Heritability and repeatability estimates of maternal performance traits in purebred and crossbred does. World Rabbit Sci. 5:99-105.

Lukefahr, S. D., H. B. Odi, and J. K. Atakora. 1996. Mass selection for 70-day body weight in rabbits. J. Anim Sci. 74:1481-1489.

Macpherson, M. L., R. C. M. Simmen, F. A. Simmen, J. Hernandez, B. R. Sheerin, D. D. Varner, P. Loomis, M. E. Cadario, C. D. Miller, S. P. Brinsko, S. Rigby, and T. L. Blanchard. 2002. Insulin-like growth factor-I and insulin-like growth factor binding protein-2 and -5 in equine seminal plasma: Association with sperm characteristics and fertility. Biol. Reprod. 67:648-654.

Maertens, L., and F. Luzi. 1997. Effect of the diet on sexual ardour and quality of semen in male rabbits. : 105-108.

Makarevich, A. V., L. Olexikova, P. Chrenek, E. Kubovicova, K. Freharova, and J. Pivko. 2007. The effect of hyperthermia in vitro on vitality of rabbit preimplantation embryos. Physiol. Res. 56:789-796.

Marai, I. F. M., A. A. Askar, and L. B. Bahgat. 2006. Tolerance of New Zealand white and californian doe rabbits at first parity to the sub-tropical environment of Egypt. Livest. Sci. 104:165-172.

Marai, I. F. M., M. S. Ayyat, and U. M. Abd El-Monem. 2001. Growth performance and reproductive traits at first parity of new zealand white female rabbits as affected by heat stress and its alleviation under egyptian conditions. J. Trop. Animal Health Prod. 33:451-462.

Marai, I. F. M., A. A. El-Darawany, A. Fadiel, and M. A. M. Abdel-Hafez. 2007. Physiological traits as affected by heat stress in sheep--a review. Small Ruminant Res 71: 1-12.

Marai, I. F. M., A. A. M. Habeeb, and A. E. Gad. 2002. Rabbits' productive, reproductive and physiological performance traits as affected by heat stress: A review. Livest. Prod. Sci. 78: 7190.

Martinez-Velazquez, G., K. E. Gregory, G. L. Bennett, and L. D. Van Vleck. 2003. Genetic relationships between scrotal circumference and female reproductive traits. J. Anim Sci. 81:395-401.

Mathur, P. K. 2002. Methods for estimation and use of genotype-environment interaction. In Proc. $7^{\text {th }}$ World Congress on Genetics Applied to Livestock Production, Montpellier, France. 32:325-332.

Meiser, H., A. Boersma, H. Bollwein, R. Stolla, and R. Schulz. 2000. The alteration of bull sperm motility by nitric oxide. Naunyn Schmiedebergs Arch. Pharmacol. 361:184.

Meyer, K. 2001. Estimates of direct and maternal covariance functions for growth of Australian beef calves from birth to weaning. Genet. Sel. Evol. 33:487-514. 
Mocé, E., R. Lavara, F. Lavara, and J. C. Vicente. 2000. Effect of reproductive rhythm on seminal parameters from a rabbit line with high growth rate. In Proc. 7th World Rabbit Congress.Valencia, Spain A:197-201.

More O'Ferrall, G. J., and T. N. Meacham. 1968. Relationship between pH, other semen traits and fertility in rabbits. VI ${ }^{6}$ Cong. Intern. Reprod. Anim. Insem. Artif. Paris. 2:1279-1281.

Morrell, J. M. 1995. Artificial insemination in rabbits. Br. Vet. J. 151:477-488.

Mortimer, D., E. F. Curtis, and R. G. Miller. 1987. Specific labelling by peanut agglutinin of the outer acrosomal membrane of the human spermatozoon. J. Reprod. Fertil. 81:127-135.

Mortimer, D., and R. Menkveld. 2001. Sperm morphology assessment - historical perspectives and current opinions. J. Androl. 22:192-205.

Moser, D. W., J. K. Bertrand, L. L. Benyshek, M. A. McCann, and T. E. Kiser. 1996. Effects of selection for scrotal circumference in Limousin bulls on reproductive and growth traits of progeny. J. Anim Sci. 74:2052-2057.

Moura, A. S. A. M. T., A. R. C. Costa, and R. Polastre. 2001. Litter and growth traits through a multi-purpose index. World Rabbit Sci. 9:77-86.

Neely, J. D., and O. W. Robison. 1983. Estimates of heterosis for sexual activity in boars. J. Anim Sci. 56:1033-1038.

Neild, D., G. Chaves, M. Flores, N. Mora, M. Beconi, and A. Agüero. 1999. Hypoosmotic test in equine spermatozoa. Theriogenology 51:721-727.

Nizza, A., C. Di Meo, and S. Taranto. 2003. Effect of collection rhythms and season on rabbit semen production. Reproduction in Domestic Animals 38:436-439.

Noguera, J. L., L. Varona, D. Babot, and J. Estany. 2002. Multivariate analysis of litter size for multiple parities with production traits in pigs: I. Bayesian variance component estimation. J. Anim Sci. 80:2540-2547.

Oh, S. H., M. T. See, T. E. Long, and J. M. Galvin. 2006a. Estimates of genetic correlations between production and semen traits in boar. Asian-Australas. J. Anim. Sci. 19:160-164.

Oh, S. H., M. T. See, T. E. Long, and J. M. Galvin. 2006b. Genetic parameters for various random regression models to describe total sperm cells per ejaculate over the reproductive lifetime of boars. J. Anim Sci. 84:538-545.

Ombelet, W., R. Menkveld, T. F. K. Kruger, and O. Steeno. 1995. Sperm morphology assessment: Historical review in relation to fertility. Hum. Reprod. Update 1:543-557.

Oseni, S., I. Misztal, S. Tsuruta, and R. Rekaya. Genetic components of days open under heat stress. J. Dairy Sci. 87:3022-3028.

Panella, F., and C. Castellini. 1990. Fattori ambientali e genetici che influiscono sulle caratteristiche del seme di coniglio. Riv. Coniglic. 8:39-41.

Panella, F., C. Castellini, and E. Facchin. 1994. Heritability of some male reproductive traits in rabbit. Cah. Options Mediterr. 8:279-283.

Papp, Z., and P. Rafai. 1988. Impact of heat stress on pregnant rabbits and on the development and viability of their foetuses. In Proc. 4th World Rabbit Congr., Budapest, Hungary. 3:470478.

Paul, C., A. A. Murray, N. Spears, and P. T. K. Saunders. 2008. A single, mild, transient scrotal heat stress causes DNA damage, subfertility and impairs formation of blastocysts in mice. Reproduction 136:73-84.

Pérez-Crespo, M., B. Pintado, and A. Gutiérrez-Adán. 2008. Scrotal heat stress effects on sperm viability, sperm DNA integrity, and the offspring sex ratio in mice. Mol. Reprod. Dev. 75:40-47. 
Perez-Sanchez, B., L. Tablado, and C. Soler. 1997. Sperm morphological abnormalities appearing in the male rabbit reproductive tract. Theriogenology 47:893-901.

Pesch, S., H. Bostedt, K. Failing, and M. Bergmann. 2006. Advanced fertility diagnosis in stallion semen using transmission electron microscopy. Anim. Reprod. Sci. 91:285-298.

Peskovicová, D., J. Wolf, E. Groeneveld, and M. Wolfová. 2002. Simultaneous estimation of the covariance structure of traits from field test, station test and litter recording in pigs. Livestock Production Science 77:155-165.

Petersson, K. J., R. Kolmodin, and E. Strandberg. 2005. Genotype by environment interaction for length of productive life in Swedish red and white dairy cattle. Acta Agriculturae Scandinavica - Section A: Anim. Sci. 55:9-15.

Piles, M., M. L. Garcia, O. Rafel, J. Ramon, and M. Baselga. 2006. Genetics of litter size in three maternal lines of rabbits: Repeatability versus multiple-trait models. Journal of Animal Science 84:2309-2315.

Piles, M., O. Rafel, J. Ramon, and L. Varona. 2005. Genetic parameters of fertility in two lines of rabbits with different reproductive potential. J. Anim. Sci. 83:340-343.

Piles, M., J. P. Sánchez, M. García-Tomás, O. Rafel, J. Ramon, and L. Tusell. 2010. Predicting male fertility from semen quality traits: Performance of different statistical procedures for model selection In Proc. 9th World Congress on Genetics Applied to Livestock Production, Leipzig, Germany. Available on line at: http://www.kongressband.de/wcgalp2010/assets/pdf/0817.pdf.

Prentice, R. L., and L. A. Gloeckler. 1978. Regression analysis of grouped survival data with application to breast cancer data. Biometrics 34:57-67.

Prud'hon, M. 1975. Le comportamnet alimentaire du lapin dépend beaucup de l'abreuvement. . Elevage, № nors série: une production d'avenir - Le lapin, 55-59.

Putney, D. J., M. Drost, and W. W. Thatcher. 1988. Embryonic development in superovulated dairy cattle exposed to elevated temperatures between days 1 to 7 after insemination. J. Reprod. Biol. 39:717-728.

Ragab, M., and M. Baselga. 2011. A comparison of reproductive traits of four maternal lines of rabbits selected for litter size at weaning and founded on different criteria. Livest. Sci. 136:201-206.

Rauw, W. M., E. Kanis, E. N. Noordhuizen-Stassen, and F. J. Grommers. 1998. Undesirable side effects of selection for high production efficiency in farm animals: A review. 56:15-33.

Ravagnolo, O., and I. Misztal. 2002. Effect of heat stress on nonreturn rate in holsteins: Fixedmodel analyses. J. Dairy Sci. 85:3101-3106.

Rege, J. E. O., F. Toe, E. Mukasa-Mugerwa, S. Tembely, D. Anindo, R. L. Baker, and A. LahlouKassi. 2000. Reproductive characteristics of ethiopian highland sheep: Ii. Genetic parameters of semen characteristics and their relationships with testicular measurements in ram lambs. Small Ruminant Res. 37:173-187.

Revelli, A., C. Costamagna, F. Moffa, E. Aldieri, S. Ochetti, A. Bosia, M. Massobrio, B. Lindblom, and D. Ghigo. 2001. Signaling pathway of nitric oxide-induced acrosome reaction in human spermatozoa. Biol. Reprod. 64:1708-1712.

Robinson, J. A. B., and M. M. Buhr. 2005. Impact of genetic selection on management of boar replacement. Theriogenology 63:668-678.

Roca, J., S. Martinez, J. M. Vazquez, X. Lucas, I. Parrilla, and E. A. Martinez. 2000. Viability and fertility of rabbit spermatozoa diluted in tris-buffer extenders and stored at 15 degrees $c$. Anim. Reprod. Sci. 64:103-112. 
Rodríguez-Martínez, H. 2003. Laboratory semen assessment and prediction of fertility: Still utopia? Reprod. Domestic Anim. 38:312-318.

Rosato, M. P., P. G. Rebollar, and N. Iaffaldano. 2006. Comparación de diluyentes en las características cualitativas del semen de conejo durante su conservación. XXXI Symposium de Cunicultura, Lorca, España. 9-13.

Rosell, J. M., and L. F. de la Fuente. 2009. Culling and mortality in breeding rabbits. Prev. Vet. Med. 88:120-127.

Roth, Z. 2008. Heat stress, the follicle, and its enclosed oocyte: Mechanisms and potential strategies to improve fertility in dairy cows. Reprod. in Domestic Anim. 43:238-244.

Roth, Z., R. Meidan, A. Shaham-Albalancy, R. Braw-Tal, and D. Wolfenson. 2001. Delayed effect of heat stress on steroid production in medium-sized and preovulatory bovine follicles. Reproduction 121:745-751.

Rydhmer, L. 2000. Genetics of sow reproduction, including puberty, oestrus, pregnancy, farrowing and lactation. Livestock Production Science 66:1-12.

Saacke, R. G., J. C. Dalton, S. Nadir, R. L. Nebel, and J. H. Bame. 2000. Relationship of seminal traits and insemination time to fertilization rate and embryo quality. Anim. Reprod. Sci. 60:663-677.

Saacke, R. G., S. Nadir, and R. L. Nebel. 1994. Relationship of semen quality to sperm transport, fertilization, and embryo quality in ruminants Theriogenology 41:45-50.

Safaa, H. M., M. E. Emarah, and N. F. A. Saleh. 2008. Seasonal effects on semen quality in black baladi and white New Zealand rabbit bucks World Rabbit Sci. 16:13-20.

Sailer, B. L., L. K. Jost, and D. P. Evenson. 1995. Mammalian sperm DNA susceptibility to in situ denaturation associated with the presence of DNA strand breaks as measured by the terminal deoxynucleotidyl transferase assay. J. Androl. 16:80-87.

Sánchez, J. P., I. Misztal, I. Aguilar, B. Zumbach, and R. Rekaya. 2009a. Genetic determination of the onset of heat stress on daily milk production in the us Holstein cattle. J. Dairy Sci. 92:40354045 .

Sánchez, J. P., and M. Piles. 2010. Genetic control of prolificacy and weaning production traits in rabbits shows interaction with in farm temperature. In Proc. 9th World Congress on Genetics Applied to Livestock Production, Leipzig, Germany. Available on line at: http://www.kongressband.de/wcgalp2010/assets/pdf/0557.pdf.

Sánchez, J. P., R. R. Rekaya, and I. Misztal. 2009b. Model for fitting longitudinal traits subject to threshold response applied to genetic evaluation for heat tolerance. Genet. Sel. Evol. 41: 10.

Santacreu, M. A. 2002. Estado y demandas actuales de los programas de mejora del conejo de carne. XI reunión nacional de mejora genética animal. Pamplona, Spain.

Santacreu, M. A., M. J. Argente, M. L. Mocé, and A. Blasco. 2000. Selection for uterine capacity. Ii response to selection estimated with a cryopreserved control population. In Proc. 7th World Rabbit Congress. Valencia, Spain. A:491-495.

Schaeffer, L. R. 2004. Application of random regression models in animal breeding. Livest. Prod. Sci. 86:35-45.

See, M. T., J. W. Mabry, and J. K. Bertrand. 1993. Restricted maximum likelihood estimation of variance components from field data for number of pigs born alive. J. Anim. Sci. 71:2905-2909.

Serrano, M., C. Diaz, and M. J. Carabaño. 2006. Modelling sperm motility of Holstein bulls using random regression methodology. In proc. 8th World Congress on Genetics Applied to Livestock Production. Belo Horizonte, Brazil. 13-18.

Shen, Q., J. H. Jiang, J. C. Tao, G. L. Shen, and R. Q. Yu. 2005. J. Chem. Inf. Model. 45:1024-1029. 
Sittmann, D. B., W. C. Rollins, K. Sittmann, and R. B. Casady. 1964. Seasonal variation in reproductive traits of New Zealand white rabbits. J. Reprod. Fert. 8:29-37.

Smital, J., L. L. De Sousa, and A. Mohsen. 2004. Differences among breeds and manifestation of heterosis in AI boar sperm output. Anim. Reprod. Sci. 80:121-130.

Smital, J., J. Wolf, and L. L. De Sousa. 2005. Estimation of genetic parameters of semen characteristics and reproductive traits in AI boars. Anim. Reprod. Sci. 86:119-130.

Sorensen, D., and D. Gianola. 2002. Likelihood, bayesian, and MCMC methods in quantitative genetics. Springer Science and Business Media, LLC, New York, NY.

Sorensen, D. A., S. Andersen, D. Gianola, and I. Korsgaard. 1995. Bayesian-inference in threshold models using Gibbs sampling. Genet. Sel. Evol. 27:229-249.

Strandberg, E., and B. Malmfors. 2006. Genetic evaluation. Available on line at: http://agtr.Ilri.Cgiar.Org/compendia/doc/comp\%20geneval.Pdf.

Swierstra, E. E., and G. W. Dyck. 1976. Influence of the boar and ejaculation frequency on pregnancy rate and embryonic survival in swine. J. Anim Sci. 42:455-460.

Thaller, G. 1998. Genetic and breeding for fertility. Interbull Bulletin 18. Proceedings International Workshop on Genetic Improvement of Functional Traits in Cattle - Fertility and Reproduction, Grub, Germany, November, 1997. 55-61.

Theau-Clément, M., J. M. Brun, J. Esparbié, J. Falières, J. Garvanèse, E. Lamothe, C. Larzul, N. Milcent, and G. Saleil. 2007. Une sélection pour la vitesse de croissance influence-t-elle la fécondance de la semence de lapin? 12èmes Journées de la Recherche Cunicole. Le Mans. France: 53-56.

Theau-Clément, M., J. M. Brun, E. Sabbioni, C. Castellini, T. Renieri, U. Besenfelder, J. Falieres, J. Esparbie, and G. Saleil. 2003. Comparaison de la production spermatique de trois souches de lapins: Moyennes et variabilités. 10èmes Journ. Rech. Cunicole, Paris, France.: 81-84.

Theau-Clément, M., C. Castellini, L. Maertens, and C. Boiti. 1998. Biostimulations applied to rabbit reproduction: Theory and practice. World Rabbit Sci. 6:179-184.

Theau-Clément, M., and J. Falières. 2005. Evaluation de la concentration de semence de lapins selon 2 méthodes: Hématimètre et nucleocounter SP100. In Proc. 11èmes Journées de la Recherche Cunicole. Paris: 95-99.

Theau-Clément, M., N. Michel, J. Esparbié, and G. Bolet. 1994. Effect of artificial photoperiods on sexual behaviour and sperm output in the rabbit. Anim. Sci. 60:143-149.

Theau-Clément, M., and A. Roustan. 1992. A study on relationships between receptivity and lactation in the doe and their influence on reproductive performances. J. Appl. Res. 15:412421.

Thom, E. C. 1958. Cooling degrees-days. Air Cond. Heating Ventil. 53:65-72.

Thrift, F. A., and D. K. Aaron. 1987. The crossbred sire: Experimental results for cattle. J. Anim Sci. 65:128-135.

Toghiani-Pozveh, S., A. A. Shadparvar, M. Moradi-Shahrbabak, and M. D. Taromsari. 2009. Genetic analysis of reproduction traits and their relationship with conformation traits in Holstein cows. Livest. Sci. 125:84-87.

Trenkle, A., and R. L. Willham. 1977. Beef production efficiency. Science 198:1009-1015.

Tusell, L., O. Rafel, J. Ramon, and M. Piles. 2009a. Genetic analysis of fertility and average daily gain in rabbit EAAP- 60th Annual Meeting of the European Federation of Animal Science EAAP, 2009, Barcelona, Spain. 15:172-172.

Tusell, L., R. Rekaya, M. López-Bejar, M. García-Tomás, C. Andreu, O. Rafel, J. Ramon, and M. Piles. 2009b. A neural networks approach for prediction fertility in rabbit using semen quality 
parameters. Joint Annual Meeting. Montreal, Québec, Canada. Breeding and Genetics: Dairy Cattle Breeding II and Rabbit Breeding. 2009. J. Anim. Sci.

van der Lende, T., M. H. A. Willemsen, J. A. M. van Arendonk, and E. B. P. G. van Haandel. 1999. Genetic analysis of the service sire effect on litter size in swine. Livest. Prod. Sci. 58:91-94.

van der Werf, J. 2001. Random regression in animal breeding. Course notes. Jaboticabal, sp Brazil november 2001. Available online at:

http://www.personal.Une.Edu.Au/ jvanderw/cfcoursenotes.Pdf. University of New England, Armidale, Australia.

Van Melis, M. H., J. P. Eler, G. J. M. Rosa, J. B. S. Ferraz, L. G. G. Figueiredo, E. C. Mattos, and H. N. Oliveira. 2010. Additive genetic relationships between scrotal circumference, heifer pregnancy, and stayability in nellore cattle. J. Anim Sci. 88:3809-3813.

Van Vleck, L. D. 1963. Genotype and environment in sire evaluation. J. Dairy Sci. 46:983-987.

Varona, L., and J. L. Noguera. 2001. Variance components of fertility in Spanish Landrace pigs. Livest. Prod. Sci. 67:217-221.

Verstegen, J., M. Iguer-Ouada, and K. Onclin. 2002. Computer assisted semen analyzers in andrology research and veterinary practice. Theriogenology 57:149-179.

Via, S., R. Gomulkiewics, G. de Jong, S. M. Scheiner, and P. H. van Tienderen. 1995. Adaptive phenotypic plasticity: Consensus and controversy. Trends in ecology and evolution 10, 212 217. 10: 212-217.

Vicente, J. S., M. P. Viudes-de-Castro, R. Lavara, and F. Lavara. 2000. Effect of male line on prolificacy from does inseminated with low sperm doses. In Proc. 7th World Rabbit Congress. Valencia, Spain A:273-277.

Vishwanath, R., and P. Shannon. 1997. Do sperm cells age? A review of the physiological changes in sperm during storage at ambient temperature. Reprod. Fertil. Dev. 9(3):321- 332.

Viudes-de-Castro, M. P., and J. S. Vicente. 1997. Effect of sperm count on the fertility and prolificity rates of meat rabbits. Anim. Reprod. Sci. 46:313-319.

Wakefield, J. C., A. F. M. Smith, A. Racine-Poon, and A. E. Gelfand. 1994a. Bayesian analysis of linear and non-linear population models by using the Gibbs sampler. Appl. Statist. 43:22012221.

Wakefield, J. C., A. F. M. Smith, A. Racine-Poon, and A. E. Gelfand. 1994b. Bayesian analysis of linear and non-linear population models by using the gibbs sampler. Journal of the Royal Statistical Society. Series C (Applied Statistics) 43:201-221.

Weigel, K. A., and R. Rekaya. 2000. Genetic parameters for reproductive traits of holstein cattle in california and minnesota. J. Dairy Sci. 83:1072-1080.

Weller, J. I., and M. Ron. 1992. Genetic analysis of fertility traits in Israeli Holsteins by linear and threshold models. J. Dairy Sci. 75:2541-2548.

Whitfield, C. H., and T. J. Parkinson. 1995. Assessment of the fertilizing potential of frozen bovine spermatozoa by in vitro induction of acrosome reactions with calcium ionophore (A23187). Theriogenology 44:413-422.

Windig, J. J., M. P. L. Calus, B. Beerda, and R. F. Veerkamp. 2006. Genetic correlations between milk production and health and fertility depending on herd environment. J. Dairy Sci. 89:17651775.

Wolc, A., I. White, V. Olori, and W. Hill. 2009. Inheritance of fertility in broiler chickens. Genet. Sel. Evol. 41:47.

Wolf, J. 2010. Heritabilities and genetic correlations for litter size and semen traits in Czech large white and Landrace pigs. J. Anim Sci. 88:2893-2903. 
Wolft, J. 2009. Genetic correlations between production and semen traits in pig. Animal 3:1094-1099.

Wright, S. 1934. An analysis of variability in number of digits in an inbred strain of Guinea pigs. Genetics 19:0506-0536.

Yagüe, G., F. Goyache, J. Becerra, C. Moreno, L. Sánchez, and J. Altarriba. 2009. Bayesian estimates of genetic parameters for pre-conception traits, gestation length and calving interval in beef cattle. Anim. Reprod. Sci. 114:72-80.

Yassein, S. A., K. G. M. Mahmoud, N. Maghraby, and O. H. Ezzo. 2008. Hot climate effects and their amelioration on some productive and reproductive traits in rabbit does. World Rabbit Sci. 16:173-181.

Zaini, A., M. G. Jennings, and H. W. G. baker. 1985. Are conventional sperm morphology and motility assessments of predictive value in subfertile men. J. Andrology 8:427-435.

Zeginiadou, T., J. Papadimas, and S. Mantalenakis. 2000. Acrosome reaction: Methods for detection and clinical significance. Andrologia 32:335-343 


\section{Chapter one. Genetic basis of semen}

\section{traits and their relationship with growth rate in rabbits}

L. Tusell, A. Legarra, M. García-Tomás, O. Rafel, J. Ramon and M. Piles

Submitted to Journal of Animal Science

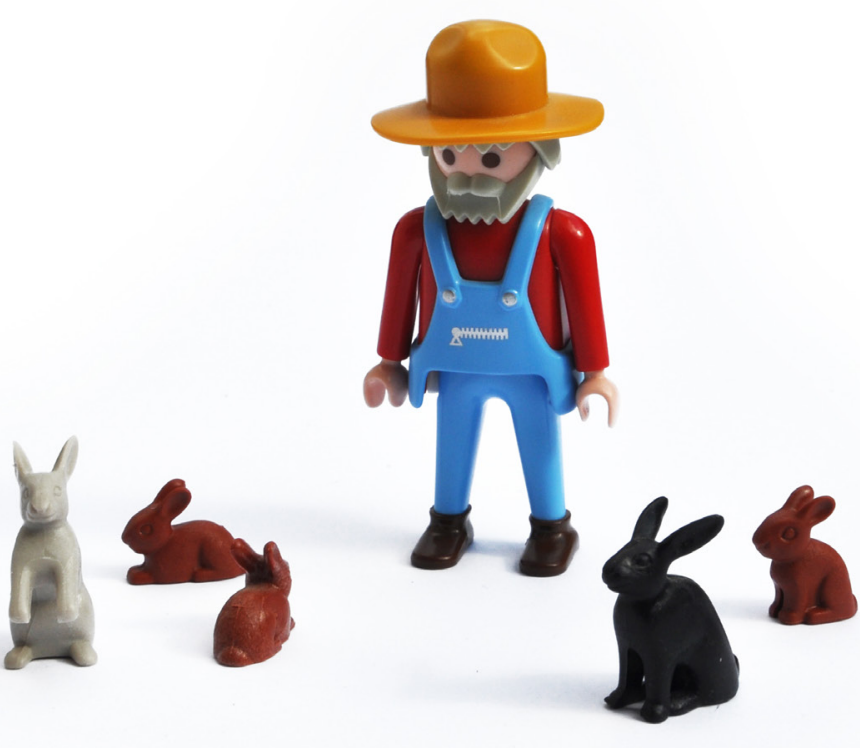

This research was supported by the Instituto Nacional de Investigación y Tecnología Agraria y Alimentaria (INIA, Madrid, Spain) project RTA2005-00088-C02. Part of it was carried out during a visit of the first author to INRA UR 631 Station d'Amélioration Génétique des Animaux (Castanet-Tolosan, France). Project partly supported by Toulouse Midi-Pyrénées bioinformatic platform (Toulouse, France). Llibertat Tusell Palomero received a fellowship from the INIA. The authors are grateful to the staff of Unitat de Cunicultura, IRTA (Caldes de Montbui, Barcelona, Spain) for their invaluable cooperation and Jamie Williams (Eolia, Missouri) for the suggestions and the English revision of the manuscript. 


\section{Abstract}

This work aims to estimate the genetic parameters of seminal and production traits in a paternal line of rabbits selected for average daily gain during the fattening period (ADG). The considered traits were: male libido (Lib) defined as successful mounting to an artificial vagina; presence of urine (Ur) and calcium carbonate deposits (Ca) in the ejaculate; semen $\mathrm{pH}$; individual sperm motility (IM); the suitability for AI of the ejaculate (Sui), which involves the subjective combination of several quality traits; the average ejaculate volume (Vol); sperm concentration (Conc); and the average sperm production per ejaculate (Prod=Vol x C). The genetic relationship between all of these traits with ADG is also provided. Male libido and seminal data came either from routine evaluations of the ejaculates in an AI center or from two experiments concerning those traits, in which bucks from the same population were used. Two consecutive ejaculates per male and per week were collected leaving 7 days within weekly collections. A linear tri-trait model was used to analyze Conc, Vol and ADG whereas linear and threshold-linear two-trait models were used to analyze male libido and the remaining seminal traits with ADG. A Bayesian approach was adopted for inference. Approximately $38 \%$ of ejaculates were rejected for AI primarily due to low IM scores. Variables related to the quality of the ejaculate (Ur, Ca, pH, IM, Sui) and Lib were found to be lowly heritable $\left(\mathrm{h}^{2}\right.$ ranged from 0.04 to 0.11 ), but repeatable. This indicates performance of bucks for seminal quality traits and libido in AI centers would be more strongly affected by management practices rather than genetic selection. Semen production traits exhibited moderate values of $\mathrm{h}^{2}(0.22,0.27$ and 0.23 for Conc, Vol and Prod, respectively) suggesting the possibility of effective selection for these traits. A moderate to high negative genetic correlation $\left(\mathbf{r}_{\mathbf{g}}\right)$ (posterior mean; highest posterior density at 95\%, HPD ${ }_{95 \%}$ ) was estimated between Conc and Vol $\left(-0.53, \mathrm{HPD}_{95 \%}=-0.76,-0.27\right)$. Because of the existence of this genetic antagonism selecting for Prod would be of most interest. The ADG was estimated to have a $\mathrm{h}^{2}$ of 0.16 , to have a low, positive $\mathrm{r}_{\mathrm{g}}$ with Conc $\left(0.21, \mathrm{HPD}_{95 \%}=-0.03,0.48\right)$, to have a low, negative $r_{g}$ with Vol $\left(-0.19\right.$, HPD $\left._{95 \%}=-0.47,0.08\right)$, and to be genetically uncorrelated with all remaining traits analyzed. Therefore, selection for increasing ADG in paternal lines is expected to have no detrimental effects on Ur, Ca, pH, IM, Sui and Lib and little to no effect on Conc, Vol and Prod.

Keywords: ejaculate quality, genetic parameters, growth, semen production, rabbit 


\section{Introduction}

Terminal bucks used for AI come from lines exclusively selected for growth traits (Baselga, 2004). Although they have good genetic merit for growth and feed efficiency no attention is placed on their reproductive performance and seminal characteristics. However, bucks used to produce doses to inseminate in commercial farms should also have good semen production and quality to potentially produce a large number of fertile doses. Optimal reproductive results are achieved with commercial AI in rabbits (e.g. $80.5 \%$ of conception rate and 10.34 number of total kits born per litter were obtained on average in French rabbit farms; ITAVI, 2008) largely because the procedures used for AI in rabbits aim to maximize the probability of fertilization of oocytes. However, efficiency of the AI centers seems to be far from optimal: the production and characteristics of semen are highly variable between collections (GarciaTomás et al., 2006b), the ejaculate rejection rate in AI centers is high (38-52\%; Brun et al., 2002a; Theau-Clément et al., 2003) and lack of libido and infertility are the most important causes for culling males in rabbit farms (Rosell and de la Fuente, 2009).

To examine the possibility of genetic improvement for increasing AI dose production per buck, this work aims to estimate the genetic parameters of the following seminal and production traits: male libido, defined as successful mounting to an artificial vagina; presence of urine and calcium carbonate deposits in the ejaculate; semen $\mathrm{pH}$; individual sperm motility; the suitability for AI of the ejaculate, which involves the subjective combination of several quality traits; the average ejaculate volume; sperm concentration; and the average sperm production per ejaculate. Additionally, genetic correlations between each semen characteristic with average daily gain were estimated to determine if selection for growth would have a correlated effect on male semen production and quality.

\section{Material and methods}

The research protocol was approved by the animal care and use committee of the Institut de Recerca i Tecnologia Agroalimentàries.

\section{Management}

Bucks belonged to the Caldes line which is selected for growth rate during the fattening period. They were bred and reared in the nucleus of selection in Caldes de Montbui (Barcelona, Spain). This farm has insulated roof and walls and cooling equipment to avoid animal exposure to extreme temperatures [e.g. the average temperature (SD) of the whole period in which the seminal data was collected was 19.5으 (3.04)]. Following weaning at $32 \mathrm{~d}$, males were housed in cages of 8 individuals with a photoperiod of $16 \mathrm{~h} \mathrm{light/d}$. Animals were 
fed a commercial diet ad libitum (15.5\% CP, 2.3\% fat, 17.2\% fiber) until d 60. Average daily gain (ADG) was measured during the fattening period (from 32 days-old to 60 days-old). After the fattening period, animals were individually housed and their feed was restricted to 180 g/d of another commercial diet (16\% CP, $4.3 \%$ fat, 17\% fiber). Fresh water was always available.

Good health status (i.e. animals free from illness, injury or pain) was the sole criterion utilized for selecting young bucks to be used both in the AI center and in the experimental studies where males were evaluated for seminal production traits.

Selected males were trained at $4.5 \mathrm{mo}$ of age to use an artificial vagina for ejaculate collection. A homemade polyvinyl chloride artificial vagina containing water at a temperature of $50^{\circ} \mathrm{C}$ was used. For ejaculate collection, the artificial vagina was hand-held beneath a doe with the open end pointed in a caudal direction and together they were placed inside the buck's cage to allow the male to mount the doe. As the buck began to mount, penetration of the male penis into the artificial vagina was allowed and the ejaculate was collected in a tube connected to the artificial vagina (for further details of the procedure refer to Morrell, 1995). In order to train young males to use an artificial vagina for ejaculate collection, one ejaculate was collected per male each week for the first $2 \mathrm{wk}$. At 5 mo of age, males were considered sexually mature, and 2 ejaculates per male each wk were collected with an interval of $30 \mathrm{~min}$ between collections within wk. Time period comprised between male ejaculate collections of two consecutive weeks was 7 days. Semen data analyzed in this study come from sexually mature males.

\section{Male libido and seminal traits data}

Male libido (sexual desire) was recorded as a binary trait (Lib $=1$ if male successfully mounted i.e., if male showed signs of falling off the doe when he did mating; 0 otherwise). Visual detection was used to identify and discard for further evaluation ejaculates contaminated with urine ( $\mathbf{U r}$, assessed by the yellowish colour of the semen instead of the typically translucent with white, grey colour), calcium carbonate deposits ( $\mathbf{C a}$, assessed by the presence of sandy sediments in the ejaculate) and blood (assessed by the pink or reddish color of the semen). Both the Ur and Ca traits were defined as binary: $1=$ presence, $0=$ absence. All gel plugs were removed. Ejaculates were stored at $37^{\circ} \mathrm{C}$ and were evaluated within $15 \mathrm{~min}$ after collection. The $\mathrm{pH}$ of the ejaculate $(\mathbf{p H})$ was determined using a 507 Crison pH-meter (Crison Instruments, S.A., Alella, Barcelona, Spain). Ejaculate volume was determined either using a graduate tube or a micro-pipette.

Ejaculates were diluted 1:4 (vol/ vol) in a commercial extender (Galap, IMV Technologies, Saint Ouen sur Iton, France). Aliquots $(25 \mu \mathrm{L})$ were evaluated under a microscope with a 
phase-contrast optic (Nikon, Lewisville, TX) at 400X magnification to assess individual sperm motility (IM). The IM of each sample was recorded and analyzed on a subjective scale that ranged from 0 to 5 , which corresponded to a percentage of sperm showing progressive movement: 0 to 10,11 to 25,26 to 50,51 to 70,71 to 90 , or 91 to $100 \%$, respectively (Roca et al., 2000).

The suitability for AI of the ejaculate (Sui) was defined as a binary trait $(1=$ suitable, $0=$ unsuitable for AI) and was assessed subjectively by a technician. An ejaculate was considered unsuitable for AI if presented any of the following characteristics: the presence of Ur, blood, and $\mathrm{Ca}$ in the ejaculate, an IM score $\leq 2$, presence of a high number (approximately $>50 \%$ ) of dead spermatozoa and the presence of clustered spermatozoa (both assessed by visual detection under microscope). As an ejaculate could present more than one characteristic of unsuitability for AI, it could be discarded for AI for more than one reason at the same time.

Seminal data of Lib, Ur, Ca, IM and Sui came from routine evaluations performed in the IRTA's AI center from December 2001 to December 2009. Within this period, data of semen $\mathrm{pH}, \mathrm{Vol}$ and Conc were collected in two experimental periods: January 2002 to December 2002 and January 2006 to September 2007. In the first experimental period, Conc was measured in each ejaculate using a Thoma Zeiss counting cell chamber. In cases where there were two ejaculates suitable for AI per male on a given day, Conc per male on the day of collection (Conc) was calculated as $\left(\mathrm{Conc}_{1} \times \mathrm{Vol}_{1}+\mathrm{Conc}_{2} \times \mathrm{Vol}_{2}\right) /\left(\mathrm{Vol}_{1}+\mathrm{Vol}_{2}\right)$ where subscripts 1 and 2 are the first and second ejaculate of the male on the day of ejaculate collection. In the second experimental period, Conc was measured using a counter of sperm cells (NucleoCounter SP-100, ChemoMetec A/S, Allerod, Denmark) after pooling semen from both suitable ejaculates for AI obtained from the same buck on the same day. No differences in Conc measurements have previously been encountered using either a haemocytometer or the Nucleocounter SP100 (Theau-Clément and Falières, 2005).

The average ejaculate volume per male each day ( Vol) was calculated as: $\left(\operatorname{Vol}_{1}+\mathrm{Vol}_{2}\right) / \boldsymbol{n}$ where $n$ is the total number of ejaculates obtained per male on the day of collection $(n=1,2)$. Collections in which the male successfully mounted the doe but no ejaculate was collected in the collection tube were considered as Vol=0 $\mathrm{mL}$.

Whenever a nonzero Vol was obtained, the average sperm production per ejaculate (Prod) was determined by multiplying Vol by Conc.

Seminal traits Lib, Ur, Ca, IM and Sui involved 883 males from approximately 740 litters, whereas $\mathrm{pH}, \mathrm{Vol}$, Conc and Prod involved 541 males from approximately 470 litters. Total numbers of records obtained for each seminal trait are presented in Table 1.1. 
There were a total of 118,306 records of ADG which corresponds to all the data from the foundation of the line. The pedigree included 118,574 animals.

Table 1.1. Summary statistics of average daily gain and seminal traits expressed as average percentage per buck

\begin{tabular}{llllll}
\hline Trait & Min. & Mean & Max. & CV & No. records \\
\hline $\mathrm{ADG}^{1}$ & 10.78 & 45.98 & 88.95 & 0.18 & 118,306 \\
$\mathrm{Lib}^{2}$ & 0 & 0.80 & 1 & 1.58 & 13,914 \\
$\mathrm{Ur}^{3}$ & 0 & 0.08 & 1 & 2.15 & 14,383 \\
$\mathrm{Ca}^{4}$ & 0 & 0.22 & 1 & 1.18 & 14,449 \\
$\mathrm{pH}^{5}$ & 6.35 & 7.45 & 8.66 & 0.05 & 1,386 \\
$\mathrm{IM}^{6}$ & 0 & 2.69 & 4.67 & 0.28 & 13,727 \\
$\mathrm{Sui}^{7}$ & 0 & 0.61 & 1 & 0.50 & 14,240 \\
$\mathrm{Conc}^{8}$ & 0 & 331.82 & 1616.04 & 0.67 & 1,290 \\
$\mathrm{Vol}^{9}$ & 0.07 & 0.77 & 2.1 & 0.53 & 1,225 \\
$\mathrm{Prod}^{10}$ & 29.875 & 670.83 & 2450.50 & 0.49 & 1,077 \\
\hline
\end{tabular}

${ }^{1} \mathrm{ADG}=$ Average daily gain during the fattening period (g/day)

${ }^{2} \mathrm{Lib}=$ male libido (binary trait: 1 = success to mount artificial vagina, $\theta=$ failure)

${ }^{3} \mathrm{Ur}=$ presence of urine in the ejaculate (binary trait: $1=$ presence, $\theta=$ absence)

${ }^{4} \mathrm{Ca}=$ presence of calcium carbonate deposits in the ejaculate (binary trait: 1 = presence, $\theta$ $=$ absence)

${ }^{5} \mathrm{pH}=\mathrm{pH}$ of the ejaculate

${ }^{6} \mathrm{IM}=$ individual sperm motility (subjective scale from $\theta$ to 5 corresponding to a percentage of sperm showing progressive movement of: $\theta$ to 10,11 to 25,26 to 50,51 to 70,71 to 90 ,

or 91 to $100 \%$, respectively)

${ }^{10} \mathrm{Sui}=$ ejaculate suitability for AI. (binary trait: $1=$ suitable, $\theta=$ unsuitable)

${ }^{4} \mathrm{Conc}=$ average sperm concentration of the ejaculate per male on the day of collection ( $\times 10^{6}$ spermatozoa/mL)

${ }^{5} \mathrm{Vol}=$ average volume of the ejaculate per male on the day of collection ( $\mathrm{mL}$ )

\section{Model and statistical analysis}

The seminal traits Lib, Ur, Ca, pH, IM, Prod and Sui were each analysed with ADG in a bivariate analysis in order to avoid selection bias in the estimates of the (co)variance components and to determine the relationship between ADG and the seminal traits. The Vol and Conc were analysed jointly with ADG in a trivariate analysis in order to estimate the correlations among the three traits. Models were Gaussian for the continuous traits pH, IM, Vol, Conc, Prod and ADG whereas threshold models were used to analyse the binary traits Lib, Ur, Ca and Sui.

The threshold model assumes the observed binary responses are indicators of an underlying continuous random variable (I) (liability; Falconer 1965) and a fixed threshold, which divides the continuous scale into two intervals and forms the two response categories (Wright, 1934).

The general model assumed for the analysis of the seminal traits was:

$$
\mathbf{y}_{s}=\mathbf{X}_{s} \boldsymbol{\beta}_{s}+\mathbf{Z}_{s} \mathbf{u}_{s}+\mathbf{W}_{1, s} \mathbf{p}_{s}+\mathbf{W}_{2, s} \mathbf{c}_{s}+\mathbf{e}_{s}
$$

where $\mathbf{y}_{\mathrm{s}}$ is a vector of data for the corresponding continuous seminal traits $(s=\mathrm{pH}, \mathrm{IM}, \mathrm{Vol}$, Conc, Prod) or a vector of liabilities corresponding to the binary seminal traits ( $s=\mathrm{Lib}, \mathrm{Ur}, \mathrm{Ca}$ and Sui), $\boldsymbol{\beta}_{\mathrm{s}}$ is a vector of systematic effects, $\mathbf{u}_{\mathrm{s}}$ is a vector of male additive genetic effects, $\mathbf{p}_{\mathrm{s}}$ is a vector of random male permanent environmental effects, $\mathbf{c}_{\mathrm{s}}$ is a vector of common litter 
environmental effects and $\mathbf{e}_{\mathrm{s}}$ is a vector of residuals. Terms $\mathbf{X}_{\mathrm{s}}, \mathbf{Z}_{\mathrm{s}} \mathbf{W}_{1, s}$ and $\mathbf{W}_{2, \mathrm{~s}}$ are incidence matrices relating data with the systematic, random genetic, random permanent environmental effects, and common litter environmental effects, respectively. The systematic effects included in the model were: order of the ejaculate ( 2 levels, first or second, this effect was not included in Vol, Conc and Prod models), year-season of collection (two mo intervals: 33 levels for Lib, Ur, Ca, IM and Sui, and 13 levels for pH, Vol, Conc and Prod) and male age (7 levels for Lib, Ur, Ca, IM and Sui: 4-6, >6-8, >8-10, >10-12, >12-16, >16-24, >20 mo and 3 levels for pH, Vol, Conc and Prod: 4-6, >6-8, >8-10 mo).

The following model was assumed for ADG:

$\mathbf{y}_{a d g}=\mathbf{X}_{a d g} \boldsymbol{\beta}_{a d g}+\mathbf{Z}_{a d g} \mathbf{u}_{a d g}+\mathbf{W}_{1, a d g} \mathbf{p}_{a d g}+\mathbf{W}_{2, a d g} \mathbf{c}_{a d g}+\mathbf{e}_{a d g}$

where $\mathbf{y}_{\text {adg }}$ is a vector of ADG measurements, $\boldsymbol{\beta}_{\text {adg }}, \mathbf{u}_{\text {adg }}$, and $\mathbf{c}_{\text {adg }}$ correspond to the same effects as those defined for seminal traits in the previous model. Because seminal traits and ADG were collected at two different time periods in a given buck's lifetime, the residual was decomposed into two terms, $\mathbf{p}_{\text {adg }}$ and $\mathbf{e}_{\text {adg }}$ where $\mathbf{p}_{\text {adg }}$ relates to the male permanent environmental effect of the corresponding seminal trait. This decomposition of the residual was carried out to increase data connectivity and to allow for estimation of a possible environmental correlation between ADG and the each seminal trait. Incidence matrices $\mathbf{X}_{\text {adg }}$ $\mathbf{Z}_{\text {,adg, }} \mathbf{W}_{1, \text { adg }}$ and $\mathbf{W}_{2, \text { adg }}$ relate growth data with the systematic, random genetic and random permanent environmental effects, respectively. The systematic effects included in the ADG model were: year-season of birth (105 levels), parity order (6 levels: 1,..,5, >5 parities) and number of kits born alive in the litter to which the individual was born (8 levels: $\leq 5,6, \ldots, 11, \geq$ 12 kits born alive).

A Bayesian framework was adopted for inference. Denote $\boldsymbol{\Omega}=\{\boldsymbol{\beta}, \mathbf{u}, \mathbf{p}, \mathbf{c}, \mathbf{G}, \mathbf{P}, \mathbf{C}, \mathbf{R}\}$ as the vector including all the unknown parameters in the model. Where $\boldsymbol{\beta}^{\prime}=\left(\boldsymbol{\beta}_{s}^{\prime}, \boldsymbol{\beta}_{a d g}^{\prime}\right)$, $\mathbf{u}^{\prime}=\left(\mathbf{u}_{s}^{\prime}, \mathbf{u}_{a d g}^{\prime}\right), \mathbf{p}^{\prime}=\left(\mathbf{p}_{s}^{\prime}, \mathbf{p}_{a d g}^{\prime}\right)$ and $\mathbf{c}^{\prime}=\left(\mathbf{c}_{s}^{\prime}, \mathbf{c}_{a d g}^{\prime}\right)$. The terms $\mathbf{G}, \mathbf{P}, \mathbf{C}$ are the different (co)variance matrices of the corresponding random effects defined above and $\mathbf{R}$ is the residual (co)variance matrix. The joint posterior distribution of all parameters for the joint analyses of two continuous traits was:

$$
p\left(\boldsymbol{\Omega} \mid \mathbf{y}_{s}, \mathbf{y}_{\text {adg }}\right) \propto p\left(\mathbf{y}_{s}, \mathbf{y}_{\text {adg }} \mid \mathbf{\Omega}\right) \times p(\mathbf{\Omega})
$$

Whereas the joint posterior distribution of all parameters for the analysis of a categorical and a continuous trait was: 


$$
p\left(\mathbf{\Omega}, \mathbf{l} \mid \mathbf{y}_{a d g}, \mathbf{y}_{s}\right) \propto p\left(\mathbf{y}_{a d g}, \mathbf{l} \mid \mathbf{\Omega}\right) \times p\left(\mathbf{y}_{S} \mid \mathbf{l}, \mathbf{\Omega}\right) \times p(\mathbf{\Omega})
$$

The assigned prior distributions for the parameters of the models were:

$$
\begin{aligned}
& p(\boldsymbol{\beta}) \sim k \quad p(\mathbf{u} \mid \mathbf{G}) \sim N(\mathbf{0}, \mathbf{G} \otimes \mathbf{A}) \quad p(\mathbf{p} \mid \mathbf{P}) \sim N(\mathbf{0}, \mathbf{P} \otimes \mathbf{I}) \\
& p(\mathbf{c} \mid \mathbf{C}) \sim N(\mathbf{0}, \mathbf{C} \otimes \mathbf{I}) \text { where } k \text { is a constant and } \mathbf{A} \text { is the numerator relationship matrix of }
\end{aligned}
$$
all the individuals. Bounded uniform prior distributions were assumed for $\boldsymbol{\beta}$ and the components of $\mathbf{G}, \mathbf{P}$ and $\mathbf{C}$. For the binary traits, the threshold and the residual variance were fixed to 0 and 1 , respectively.

For the continuous traits, the prior distribution for the residuals was $p(\mathbf{e} \mid \mathbf{R}) \sim N(\mathbf{0}, \mathbf{R} \otimes \mathbf{I})$ and bounded uniform priors were assumed for the elements of $\mathbf{R}$.

The off-diagonal elements of $\mathbf{R}$ were always set to zero except in the trivariate analyses were the elements corresponding to the residual covariance between Vol and Conc was estimated.

The marginal posterior distributions of the parameters of interest were derived from the joint posterior density of all the unknowns. The Gibbs sampler algorithm was used to estimate the marginal posterior distributions of the systematic effects and the (co)variance components using the TM software developed by Legarra et al. 2008. Conditional distributions of the model parameters, necessary for the implementation of this algorithm, can be found in Sorensen and Gianola (2002). Single chains of 1,000,000 and 3,000,000 iterations were run discarding the first 250,000 and 1,000,000 iterations of each chain in the bivariate and trivariate analyses, respectively. Samples of the parameters of interest were saved every 100 rounds. The number of discarded samples was, in all cases, much larger than the required burn-in determined by the procedures of Raftery and Lewis (1992) and Geweke (1992). The sampling variance of the chains was obtained by computing Monte Carlo standard errors (Geyer, 1992). Summary statistics from the marginal posterior distributions were calculated directly from the samples saved.

\section{Results and discussion}

\section{Summary statistics of ADG and seminal traits}

Summary statistics for the seminal traits and ADG are shown in Table 1.1.

Means of the different seminal traits were within the range of values obtained for rabbits in previous studies reviewed by Alvariño (2000). The mean of ADG was also in accordance with 
those obtained in other rabbit lines (Vogt, 1979; Moura et al., 1997; Lavara et al., 2011). A large portion of the seminal and Lib data came from routine evaluations performed in the AI center; therefore it is possible that there is some bias associated with these raw means. This potential for bias stems from the selection strategy followed by this AI center in which bucks are replaced based upon a lack of libido and poor sperm production. After 3 mo in production, buck replacement is only performed in older bucks, for reasons of lack of libido, poor sperm production and quality and poor health status, being the last one the most common reason for buck culling in the AI centre. Because bucks with poor libido and poor sperm production and quality are only replaced after being 3 mo in production; presumably this selection strategy will not have a large effect on the estimates of male variance components because enough data is colleted per individual.

The percentage of successful collection rate with the artificial vagina was very high and, in agreement with the one obtained in previous studies. This result contributes to reflect the high adaptability of this species to be used in AI centers for dose production (Brun et al., 2002a; Theau-Clément et al., 2003; Brun et al., 2006).

However, the efficiency in the use of bucks in AI centers still seems to be less than optimal. A low percentage $(62 \%)$ of ejaculates were considered suitable for AI and this estimate is in agreement with similar studies performed on rabbits (Brun et al., 2002a; Theau-Clément et al., 2003; Brun et al., 2006; Garcia-Tomás et al., 2006c). These results suggest criteria for ejaculate rejection could be too restrictive and/or that, in some cases, it could be necessary to improve the qualitative characteristics of the ejaculate through management procedures or genetic selection. Low IM was the main reason for ejaculate rejection in this line (representing a $66 \%$ of total rejections), followed by the presence of $\mathrm{Ca}$ and Ur in the ejaculates (see Figure 1.1).

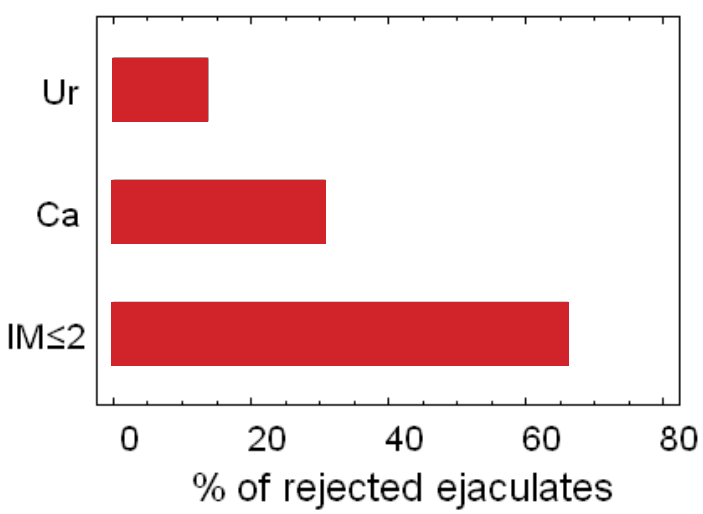

Figure 1.1. Relative importance of several causes of ejaculate rejection for AI: presence of urine (Ur), presence of calcium carbonate deposits (Ca) and individual motility score less than or equal to 2 (IM 2) in a subjective scale from 0 to 5 corresponding to a percentage of sperm showing progressive movement of: 0 to 10,11 to 25,26 to 50,51 to 70 , 71 to 90 , or 91 to $100 \%$, respectively. 
Sperm concentration and sperm motility are considered important parameters influencing fertility (Castellini and Lattaioli, 1999; Brun et al., 2002b; Lavara et al., 2005; Garcia-Tomás et al., 2006a). For that reason, individual and/or mass motility score are commonly used as criteria for ejaculate rejection in most AI centers. Conversely, individual sperm concentration is not commonly evaluated in rabbits because pooling ejaculates from several bucks is a common practice in rabbit AI centers. Thus, sperm concentration is only measured in the pooled ejaculate in order to perform the proper dilution to reach the standardized concentration of a heterospermic commercial dose.

Presence of urine in the ejaculate has been found to be one of the principal factors for ejaculate rejection in rabbits (Brun et al., 2002a; Theau-Clément et al., 2003; Brun et al., 2006). Calcium carbonate deposits, which in this line were present in $17 \%$ of ejaculates, are also encountered in the bladder. However, sources of this Ca origin are still unknown and, to our knowledge, their presence has only been noted in a previous study carried out on the same experimental farm (Garcia-Tomás et al., 2006c). In that study, presence of Ca was observed in another line but at a lower frequency, indicating there could be differences between lines in the expression of this trait. In order to optimize the management of the bucks in the AI center, further research should be carried out to establish the origin and causes of the presence of $\mathrm{Ca}$ in the ejaculates. The presence of $\mathrm{Ca}$ in the ejaculates complicates the evaluation of the ejaculate for seminal quality in the lab and may have a detrimental effect on reproductive performance.

The $\mathrm{pH}$ of the semen was within the range of values obtained in the same line and in other rabbit breeds (Brun et al., 2002b; Garcia-Tomás et al., 2006c; Brun et al., 2009). The pH could be considered a general semen quality indicator: the higher the concentration and motility of the spermatozoids in the ejaculate, the higher the production of lactic acid due to the greater metabolic activity and the lower the pH (Coffey, 1988; Brun et al., 2009). As a consequence, the value of this trait lies in its relationship with fertility (Brun et al., 2002b; Tusell et al., 2010). As this trait is not expensive to measure, it could be of interest to include semen $\mathrm{pH}$ in routine measurements of the AI centers in order to select ejaculates to be used for AI to improve both conception rates and the selection of the most fertile males to use in the AI centers.

\section{(Co)variance components estimates}

Table 1.2 shows features of the estimated marginal posterior distributions (EMPD) corresponding to the ratios between variance components and phenotypic variances for ADG and the seminal traits. Parameter estimates of the effects included in the ADG model did not change among the analyses. Therefore, for simplicity, only ADG estimates obtained in one of the models are presented (bivariate model with ADG and Lib). 
Table 1.2. Mean (Highest posterior density interval at $95 \%$ in brackets, and Monte Carlo standard error in parentheses) of the marginal distribution of heritability ( ${ }^{2}$ ), phenotypic variance $\left(\sigma^{2}\right)$, ratio of variance of male permanent (pm) and common litter (c) environmental effects to phenotypic variance for average daily gain and seminal traits

\begin{tabular}{|c|c|c|c|c|}
\hline Trait & $\begin{array}{l}\text { Parameter } \\
\mathrm{h}^{2}\end{array}$ & $\mathrm{pm}$ & C & $\sigma^{2}$ \\
\hline & 0.16 & 0.27 & 0.29 & 52.17 \\
\hline $\mathrm{ADG}^{1}$ & $\begin{array}{l}{[0.14,0.18]} \\
(0.001)\end{array}$ & $\begin{array}{l}{[0.13,0.44]} \\
(0.011)\end{array}$ & $\begin{array}{l}{[0.28,0.30]} \\
(0.000)\end{array}$ & $\begin{array}{l}{[51.49,52.82]} \\
(0.015)\end{array}$ \\
\hline $\mathrm{Lib}^{2,11}$ & $\begin{array}{l}0.06 \\
{[0.03,0.09]} \\
(0.002)\end{array}$ & $\begin{array}{l}0.10 \\
{[0.05,0.14]} \\
(0.003)\end{array}$ & $\begin{array}{l}0.04 \\
{[0.00,0.08]} \\
(0.003)\end{array}$ & $\begin{array}{l}1.24 \\
{[1.20,1.28]} \\
(0.001)\end{array}$ \\
\hline$U r^{3,11}$ & $\begin{array}{l}0.04 \\
{[0.02,0.07]} \\
(0.002)\end{array}$ & $\begin{array}{l}0.07 \\
{[0.04,0.10]} \\
(0.002)\end{array}$ & $\begin{array}{l}0.02 \\
{[0.00,0.04]} \\
(0.001)\end{array}$ & $\begin{array}{l}1.15 \\
{[1.12,1.18]} \\
(0.001)\end{array}$ \\
\hline $\mathrm{Ca}^{4,11}$ & $\begin{array}{l}0.08 \\
{[0.04,0.12]} \\
(0.003)\end{array}$ & $\begin{array}{l}0.11 \\
{[0.08,0.15]} \\
(0.002)\end{array}$ & $\begin{array}{l}0.02 \\
{[0.00,0.04]} \\
(0.001)\end{array}$ & $\begin{array}{l}1.27 \\
{[1.24,1.31]} \\
(0.001)\end{array}$ \\
\hline $\mathrm{pH}^{5}$ & $\begin{array}{l}0.11 \\
{[0.05,0.18]} \\
(0.005)\end{array}$ & $\begin{array}{l}0.18 \\
{[0.11,0.25]} \\
(0.004)\end{array}$ & $\begin{array}{l}0.03 \\
{[0.00,0.06]} \\
(0.002)\end{array}$ & $\begin{array}{l}0.23 \\
{[0.21,0.26]} \\
(0.001)\end{array}$ \\
\hline $\mathrm{IM}^{6}$ & $\begin{array}{l}0.08 \\
{[0.04,0.13]} \\
(0.003)\end{array}$ & $\begin{array}{l}0.14 \\
{[0.10,0.19]} \\
(0.002)\end{array}$ & $\begin{array}{l}0.02 \\
{[0.00,0.05]} \\
(0.001)\end{array}$ & $\begin{array}{l}1.16 \\
{[1.12,1.21]} \\
(0.001)\end{array}$ \\
\hline Sui ${ }^{7,11}$ & $\begin{array}{l}0.06 \\
{[0.03,0.09]} \\
(0.002)\end{array}$ & $\begin{array}{l}0.12 \\
{[0.08,0.15]} \\
(0.002)\end{array}$ & $\begin{array}{l}0.02 \\
{[0.00,0.05]} \\
(0.001)\end{array}$ & $\begin{array}{l}1.25 \\
{[1.22,1.29]} \\
(0.001)\end{array}$ \\
\hline Conc $^{8}$ & $\begin{array}{l}0.27 \\
{[0.14,0.31]} \\
(0.005)\end{array}$ & $\begin{array}{l}0.17 \\
{[0.09,0.25]} \\
(0.004)\end{array}$ & $\begin{array}{l}0.05 \\
{[0.01,0.11]} \\
(0.003)\end{array}$ & $\begin{array}{l}57,459.38 \\
{[51,263.54} \\
63,775.80] \\
(193.05)\end{array}$ \\
\hline $\operatorname{Vol}^{9}$ & $\begin{array}{l}0.23 \\
{[0.14,0.31]} \\
(0.004)\end{array}$ & $\begin{array}{l}0.18 \\
{[0.09,0.26]} \\
(0.004)\end{array}$ & $\begin{array}{l}0.06 \\
{[0.01,0.11]} \\
(0.002)\end{array}$ & $\begin{array}{l}0.21 \\
{[0.19,0.23]} \\
(0.000)\end{array}$ \\
\hline $\operatorname{Prod}^{10}$ & $\begin{array}{l}0.23 \\
{[0.13,0.32]} \\
(0.005)\end{array}$ & $\begin{array}{l}0.15 \\
{[0.06,0.23]} \\
(0.005)\end{array}$ & $\begin{array}{l}0.05 \\
{[0.01,0.10]} \\
(0.002)\end{array}$ & $\begin{array}{l}134,269.6 \\
{[120,109.75} \\
148,660.45] \\
(465.94)\end{array}$ \\
\hline \multicolumn{5}{|c|}{ 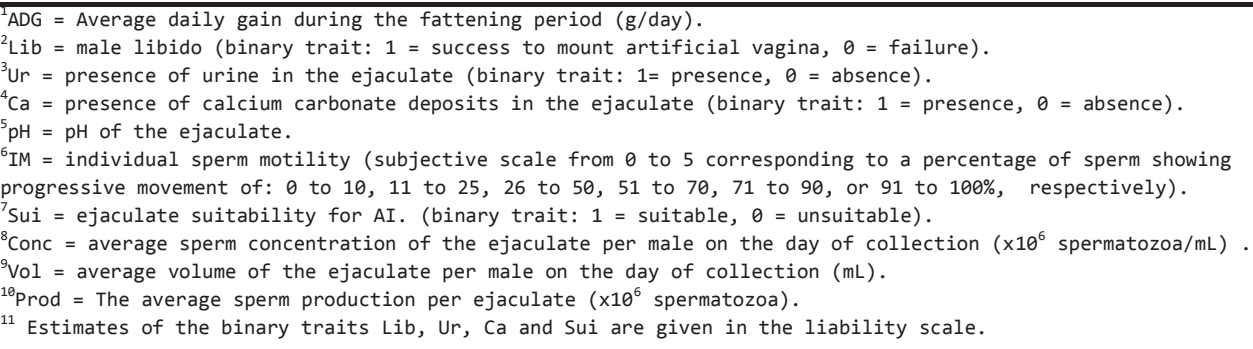 } \\
\hline
\end{tabular}

The heritability $\left(\mathbf{h}^{2}\right)$ for ADG was in accordance with estimates from previous studies obtained in other rabbit lines (Larzul and Gondret, 2005; Lavara et al., 2011) and in the same line (Piles et al., 2004).

Seminal traits showed low to moderate values of $\mathrm{h}^{2}$ and repeatability ( $\mathrm{r}$; calculated as the sum of the $\mathrm{h}^{2}$ and the ratios of variance of male permanent and common litter environmental effects). The ratios of variance of the male permanent environmental effects ranged from 0.07 to 0.18 for all the seminal traits. The proportion of variance due to the common litter effect 
was almost null for the seminal traits whereas it represented a high proportion of the total phenotypic variance for ADG in agreement with results obtained by Lavara et al. (2011) and Piles et al. (2004).

Male libido and presence of urine and calcium carbonate deposits in the ejaculate

Traits Lib, Ur and Ca were found to be lowly heritable, which could be attributed in part to the great variability inherent in these traits due to factors involved in semen collection (i.e.: variation in the temperature of the artificial vagina that could lead to a higher presence of $\mathrm{Ur}$ and $\mathrm{Ca}$ in the ejaculate or unsuccessful mountings) (Morrell, 1995). Therefore, genetic selection for increasing semen production by improving Lib and reducing the number of rejected ejaculates may not be effective. To our knowledge, there is no information in the literature concerning male $\mathrm{h}^{2}$ for presence of Ur and Ca in the ejaculates. Classifying Lib into 3 categories (no mating, collection after 5 min and intermediate collection), Panella et al. (1994) reported $\mathrm{a} \mathrm{h}^{2}$ of Lib of 0.30 in rabbits. However, results obtained in that work should be taken with caution because all the genetic parameter estimates for seminal traits were unusually high, likely due to the absence in their model of a permanent environmental effect related to the male. Khalil et al. (2007) estimated the $\mathrm{h}^{2}$ of Lib divided into 5 classes (from 1 for low libido to 5 for strong libido) using data from bucks coming from two rabbit lines and their reciprocal crosses. They found a higher estimate for this parameter than the one obtained in our study, due in part to the heterogeneity of the genetic type of the bucks. Flowers (2008) concluded that it would be difficult to improve Lib and mating behaviors in boars trough genetic selection due to the low phenotypic variation they observed for these traits in several studies.

The posterior mean [High posterior density interval at 95\%] (PM [HPD ${ }_{95 \%}$ ]) of the male repeatability (r) for Ca was $0.21[0.19,0.24]$ indicating a certain stability of the values of this trait over collections of the same male. However, the magnitude of this parameter is not high enough to make decisions concerning buck replacement according to this trait at the beginning of the production period of the male.

\section{Individual sperm motility and semen $\mathrm{pH}$}

The IM was also found to be lowly heritable and repeatable. The PM [HPD ${ }_{95 \%}$ ] of $\mathrm{r}$ was 0.25 $[0.22,0.28]$. Estimates reported by other authors in rabbits are in agreement with these results for IM or mass motility score (Bencheikh, 1995; Brun et al., 2009) and with the percentage of progressive motility in different breeds of boars (Wolft, 2009) and bulls (Karoui et al., 2011). This low heritability and repeatability could be due in part to the great variability 
of this trait originating from semen manipulation and time elapsed until evaluation as well as to the subjective manner in which this trait is measured since it is determined by the technician.

The low $\mathrm{h}^{2}$ for Sui is in accordance with the estimate obtained for the subjective semen score used in bulls (Knights et al., 1984) which, in turn, had a high $r_{g}$ with Conc and Vol, perhaps because they were the most important traits taken into consideration for scoring ejaculates. The effect of the technician (Theau-Clément et al., 2009) probably introduces some error to the criterion that determines Sui, lowering the obtained $\mathrm{h}^{2}$.

The PM of the $\mathrm{pH} \mathrm{h} \mathrm{h}^{2}$ was similar to the value previously reported in rabbits by Brun et al. (2009) and lower than the one obtained in a previous study using a subset of the data analyzed here (0.18; Tusell et al., 2010). The difference between the $\mathrm{h}^{2}$ values obtained with these two sets of data could be due to the fact that in the previous study the analyzed trait was the $\mathrm{pH}$ corresponding to the pooled semen obtained from each male on the day of collection. Higher $\mathrm{h}^{2}$ estimates are obtained if traits consist of means (or weighted means) of observations of two consecutive measurements or means of several records than if the trait comes from the data of individual records. This fact has been previously denoted for seminal traits by several authors (Ducrocq and Humblot, 1995; Wolft, 2009). The PM [HPD ${ }_{95 \%}$ ] of repeatability of $\mathrm{pH}$ was $0.33[0.26,0.39]$, similar to the value obtained in a previous study where a subset of the data analyzed here were jointly analyzed with data corresponding to bucks from another paternal line and their reciprocal crosses (0.38; Garcia-Tomás et al., 2006b).

\section{Sperm production traits}

The Conc and Vol traits showed moderate to high values of repeatability (PM [HPD ${ }_{95 \%}$ ]: 0.48 $[0.42,0.55]$ for Conc and $0.46[0.40,0.53]$ for Vol) indicating the existence of important individual variation for both traits. Similar values were obtained by García-Tomás et al. (2006b). Bencheikh (1995) estimated a repeatability around 0.38 for Vol and 0.35 for Conc whereas More O'Ferrall and Meacham (1968) obtained a value of 0.29 for Vol, all of them in rabbit.

The $\mathrm{h}^{2}$ for these traits (Conc and Vol) were higher than estimates previously reported in rabbits by Brun et al. (Brun et al., 2009) and Lavara et al. (2011) analyzing records from single ejaculates ( 0.10 and 0.08 for Conc, 0.13 and 0.10 for Vol, respectively), whereas the ratios of permanent environmental effects for males were similar. In general, there is a wide range of values of heritability and repeatability of $\mathrm{Vol}$ and Conc in different species varying from extremely low to high values (Robinson and Buhr, 2005) and it is clear that the variation in 
magnitude found in the literature depends highly upon the definition of the trait (i.e. individual ejaculates or average values).

The EMPD of the genetic, non-additive genetic plus permanent environmental male effect and phenotypic correlations between Conc and Vol are shown in Figure 1.2. All the Monte Carlo standard errors (MCse) for the estimates of these correlations were lower than 0.02 .
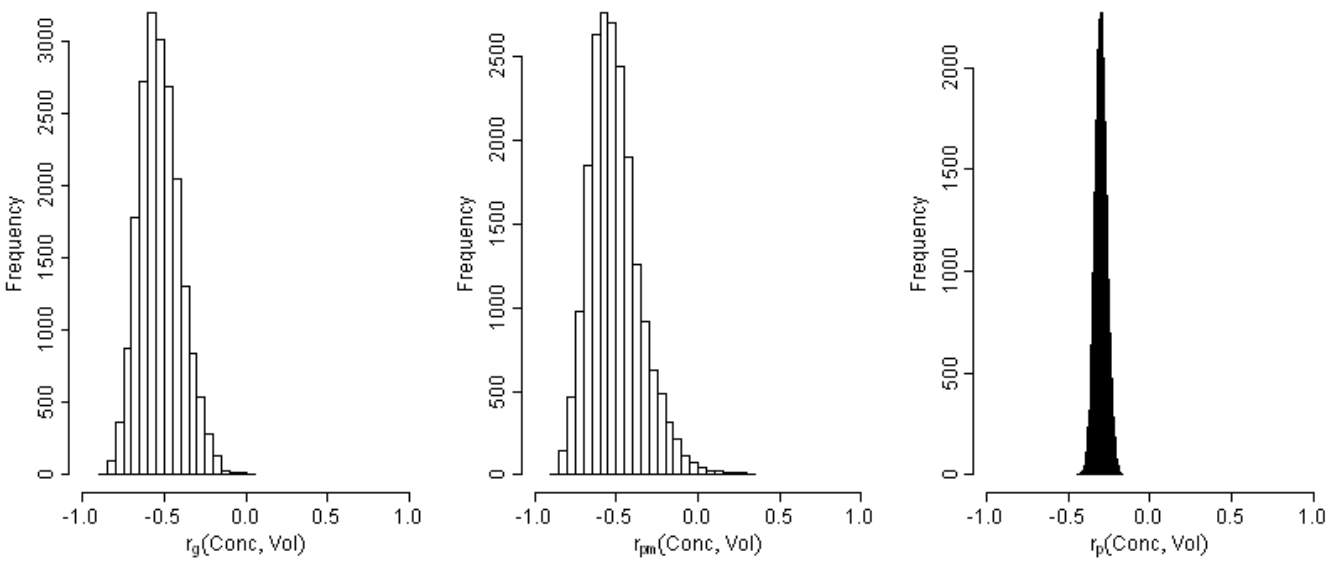

Figure 1.2. Estimated marginal posterior distributions of the genetic $(r()$.$) , male non-$ additive genetic permanent environmental $(r()$.$) and phenotypic (r()$.$) correlation$ between average sperm concentration (Conc) and average volume (Vol) of the ejaculate on the day of collection.

The genetic correlation $\left(\mathbf{r}_{\mathbf{g}}\right)$ between Conc and Vol was moderate and negative (PM:-0.53; $\mathrm{HPD}_{95 \%}$ : $\left.[-0.76,-0.27]\right)$. Several studies also reported similar values of this $r_{\mathrm{g}}$ in cattle $(-0.4$ on average; Ducrocq and Humblot, 1995; Basso et al., 2005), sheep (-0.36 on average in adult males; Rege et al., 2000; David et al., 2007), goats (-0.33 on average; Furstoss et al., 2009) and pigs (-0.60 on average; Smital et al., 2005; Wolf and Smital, 2009). Conversely, Brun et al. (2009) obtained in rabbits a $r_{g}$ between Conc and Vol that could not be considered different from $0(0.38 \pm 0.45)$. Their estimate of the correlation between Conc and Vol did not agree with that in the current study, their negative correlation between permanent environmental effects of the male did $(-0.47 \pm 0.14$ and PM:-0.51, HPD $95 \%$ : $[-0.78,0.18]$ in Brun et al. (2009) and in our work, respectively). In boars, Smital et al. (2005) also estimated the $r_{g}$ between Conc and Prod (0.21) and between Vol and Prod (0.63), respectively. They obtained a similar $\mathrm{r}_{\mathrm{g}}$ between Conc and Vol to that in the current study $(-0.61)$ indicating that a higher ejaculate volume does not seem to be associated with a higher number of sperm in the ejaculate that could remain constant or even decrease. Alternatively, Karoui et al. (2011), in bulls, the cause of higher concentration of sperm in the ejaculates seems to be the higher number of sperm, leading them to obtain a negative but smaller $r_{g}$ between Conc and Vol because the $r_{g}$ between Conc and Prod and $\mathrm{r}_{\mathrm{g}}$ between Vol and Prod were 0.60 and 0.66 , respectively. 
Prod exhibited a moderate $\mathrm{h}^{2}$ and a moderate to high repeatability (PM [HPD $95 \%$ ]: 0.42 [0.35, 0.49]), both values being higher than the corresponding values obtained by Lavara et al. (2011) and Brun et al. (2009) for individual ejaculates. The repeatability for Prod was estimated to be 0.33 in previous research by Garcia-Tomás et al. (2006b) with both purebred and crossbred bucks. Smital et al. (2005) proposed either total number of spermatozoa or number of insemination doses produced at a certain dosage for developing a composite trait for breeding purposes.

\section{Correlations between ADG and seminal traits}

The correlation $\left(\mathbf{r}_{\mathbf{c o}}\right)$ between common birth litter effects for ADG and the seminal traits was very low, including zero in the HPD ${ }_{95 \%}$ except for Ca. For the last trait, the PM [HPD $\left.{ }_{95 \%}\right]$ of $\mathrm{r}_{\mathrm{co}}$ was $0.37[0.01,0.81]$ suggesting that favourable effects for growth could be detrimental for the production of ejaculates free of Ca. However, the accuracy of this correlation estimate is very low because of the low magnitude of this variance component for Ca. It is necessary to know the origin and causes of this trait in order to better understand the nature of this relationship. The EMPD of the genetic, the non-additive genetic permanent environmental male effects, and the phenotypic correlations between ADG and the seminal traits are shown in Figures 1.3, 1.4, and 1.5, respectively. All the MCse for the estimates of these correlations were lower than 0.02 . 

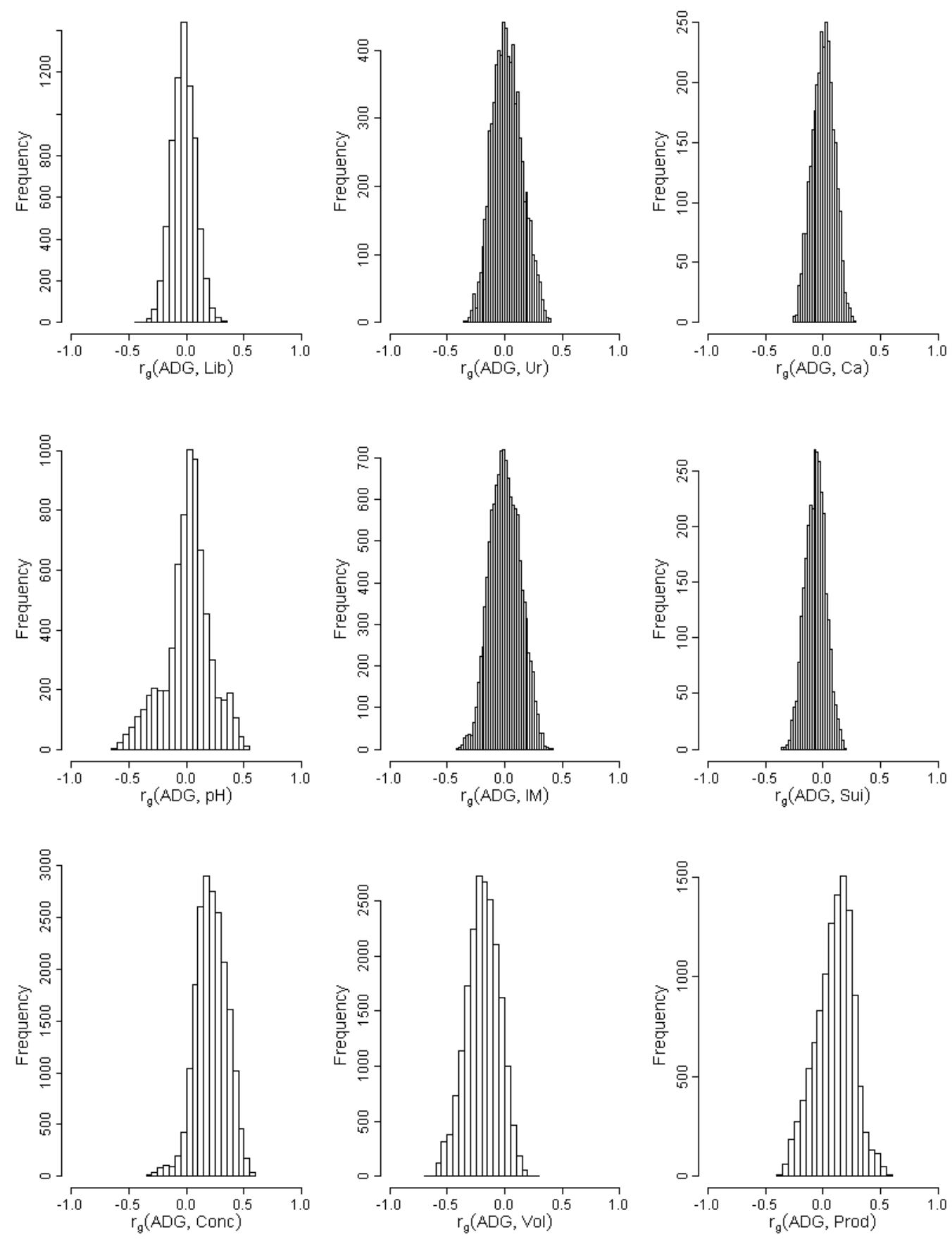

Figure 1.3. Estimated marginal posterior distributions of the genetic correlation $(r()$. between average daily gain during the fattening period (ADG) and the following seminal traits: male libido (Lib), presence of urine (Ur) and calcium carbonate deposits (Ca) in the ejaculate, semen $\mathrm{pH}$, individual motility score (IM), and suitability for AI (Sui) of the ejaculate, average sperm concentration (Conc), average volume (Vol), and average sperm production per ejaculate (Prod). 

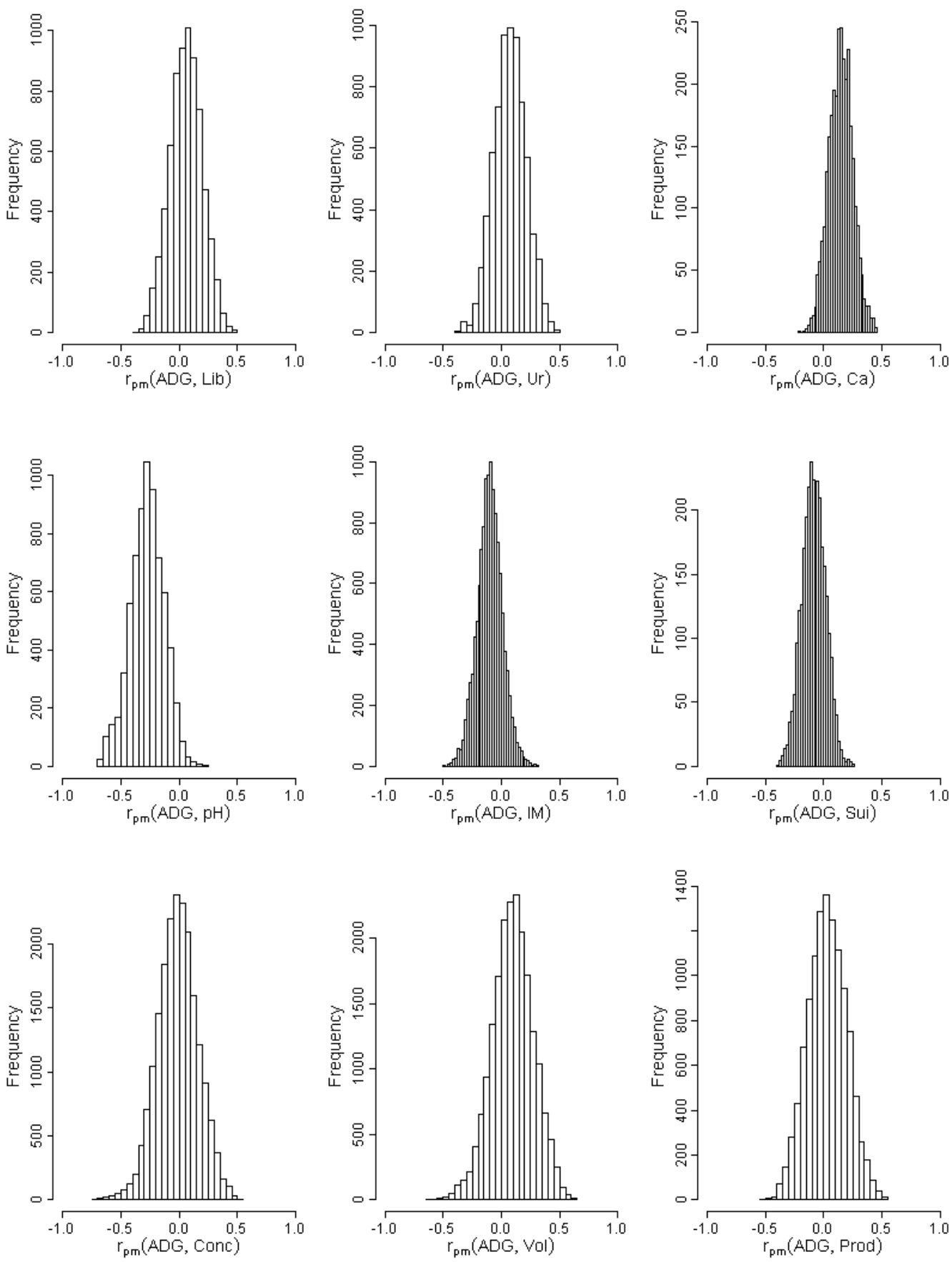

Figure 1.4. Estimated marginal posterior distributions of the male non-additive genetic permanent environmental correlation $(r()$.$) between average daily gain during the fattening$ period ( $A D G$ ) and the following seminal traits: male libido (Lib), presence of urine (Ur) and calcium carbonate deposits ( $\mathrm{Ca}$ ) in the ejaculate, semen $\mathrm{pH}$, individual motility score (IM), and suitability for AI (Sui) of the ejaculate, average sperm concentration (Conc), average volume ( $\mathrm{Vol})$, and average sperm production per ejaculate (Prod) 

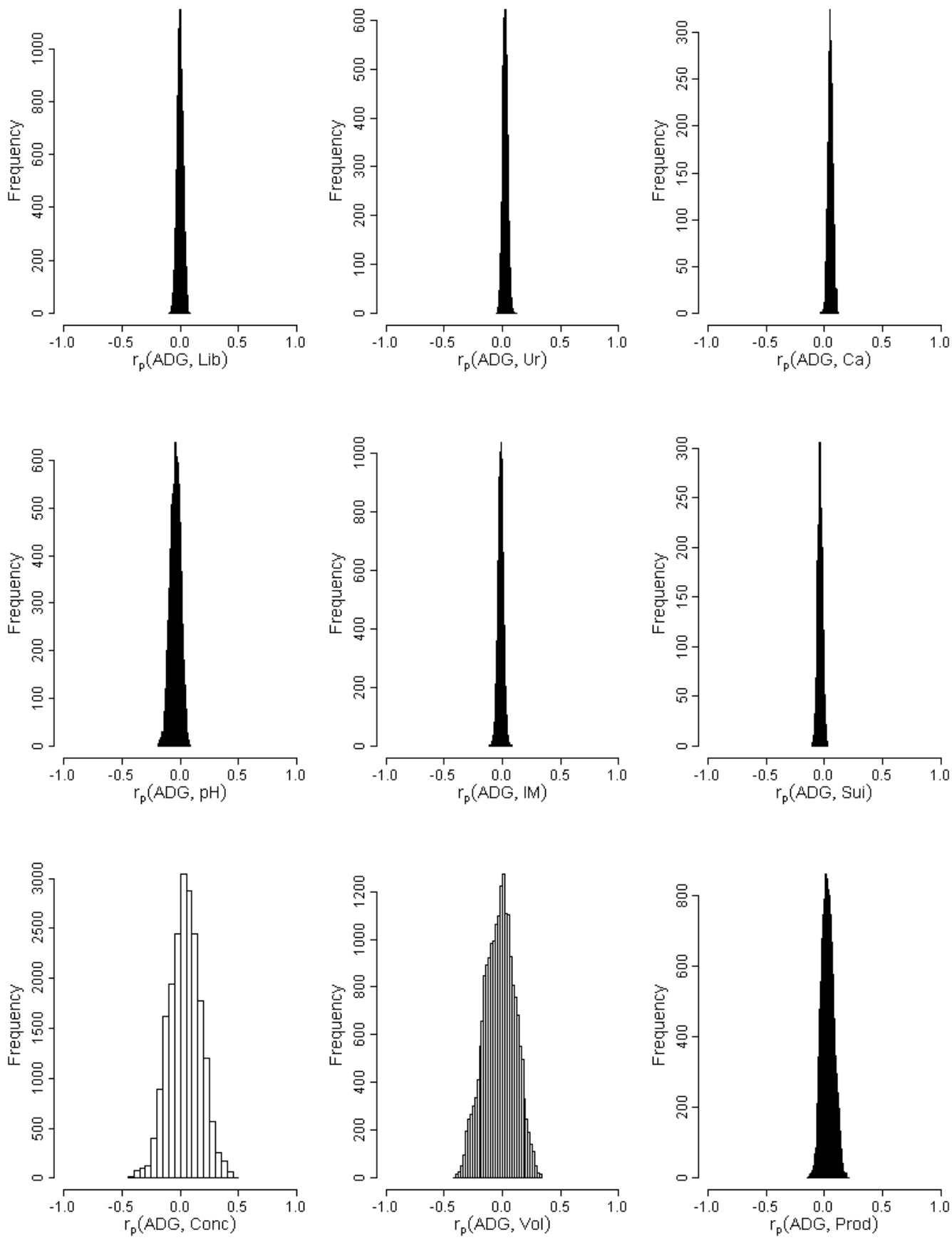

Figure 1.5. Estimated marginal posterior distributions of the phenotypic correlation $(r()$. between average daily gain during the fattening period (ADG) and the following seminal traits: male libido ( $\mathrm{Lib}$ ), presence of urine (Ur) and calcium carbonate deposits (Ca) in the ejaculate, semen $\mathrm{pH}$, individual motility score (IM), and suitability for AI (Sui) of the ejaculate, average sperm concentration (Conc), average volume (Vol), and average sperm production per ejaculate (Prod). Phenotypic correlation between ADG and binary traits (Lib, Ur, Ca and Sui) were based on liability scale. 
All the correlations between male non-additive genetic permanent environmental effects for $\mathrm{ADG}$ and the seminal traits were of low magnitude (Figure 1.4) and a similar pattern was observed for the phenotypic correlations (Figure 1.5).

Selection for increasing ADG would have a favourably correlated response on sperm concentration because the $r_{g}\left(P M\left[\mathrm{HPD}_{95 \%}\right]\right.$ ) between ADG and Conc, although low, was positive $\left(0.21[-0.03,0.48]\right.$; Figure 1.3). This result is consistent with the low, but negative $r_{g}$ between ADG and Vol (-0.19 [-0.47, 0.08]); Figure 1.3). The antagonism between Conc-ADG and Vol-ADG seems to influence the near zero genetic relationship between Prod and ADG $(0.10[-0.26,0.38])$. In another paternal line of rabbits also selected for growth rate, the $r_{g}$ between Conc, Vol and Prod with ADG was estimated to be $-0.09,0.36$ and 0.17 , respectively (Lavara et al., 2011). However in that work, estimated $r_{g}$ had wide HPD $95 \%$ making it difficult to draw unambiguous conclusions. Our estimates are in accordance with the phenotypic results obtained in an experiment of divergent selection for body weight in rabbits in which the high line had higher sperm concentration and less ejaculate volume than the low line (Brun et al., 2006). Other estimates, reported in pigs, confirm that genetic correlations between growth and Vol, Conc and Prod were negative, null or positive, but always had low magnitude (Oh et al., 2006; Wolft, 2009).

None of the genetic correlations between ADG and the other seminal traits analysed in this work can be considered different from zero. Because of the null or very low magnitude of the genetic correlation between ADG and seminal traits, we would not expect selection for growth rate in this paternal line of rabbits to damage semen production. No effect in Lib was encountered when two rabbit lines divergently selected for body weight were compared in terms of rate of successful solicitations and in the average time until ejaculation (Brun et al., 2006). In boars, Wolft (2009) reported low values of the genetic correlations between ADG and sperm motility, percentage of abnormal spermatozoa and, the composite trait, number of functional spermatozoa.

\section{Conclusions}

Male libido and seminal traits related to the quality of the ejaculate (Ca, Ur, pH and IM) seemed to be lowly heritable but repeatable. This indicates performance of bucks for seminal quality traits and libido in AI centers would be more strongly affected by management practices rather than genetic selection.

Moderate $\mathrm{h}^{2}$ were estimated for Conc, Vol and Prod suggesting the possibility of effectively selecting for increased sperm production in paternal lines. Because of the existence of a genetic antagonism between Conc and Vol, selecting for Prod would be of most interest as it encompasses both traits. 
Average daily gain had a slightly favorable genetic correlation with Conc, slightly unfavorable genetic correlation with Vol, and was genetically uncorrelated with all remaining seminal traits analyzed. Therefore, selection for increasing ADG in paternal lines is not expected to have detrimental correlated effects on seminal traits involved in sperm production. However, in order to improve the efficiency of bucks for AI dose production, it would be necessary to evaluate the expected response to selection applying different strategies and under different scenarios.

\section{Literature cited}

Alvariño, J. M. R. 2000. Reproductive performance of male rabbits. Proc. 7th World Rabbit Congr., Valencia, Spain A:13-35.

Baselga, M. 2004. Genetic improvement of meat rabbits. Programmes and diffusion. Proc. 8th World Rabbit Congr., Puebla, Mexico 1:1-13.

Basso, B., S. Fritz, T. Druet, F. Guillaume, M. N. Rossignil, Y. Amigues, R. Gabriel, E. Sellem, L. Salas-Cortes, P. Humblot, and X. Druart. 2005. Estimation de paramètres génétiques et détection de QTL liés à des caractères de fertilité mâle, de production de semence et de qualité de la semence chez le taureau laitier. 2005. In: Rencontre Recherche Ruminants, Paris 145148.

Bencheikh, N. 1995. The effect of frequency of ejaculation on semen characteristics and sperm output in the rabbit. Ann. Zootech. 44:263-279.

Brun, J. M., A. Sanchez, R. Duzert, G. Saleil, and M. Theau-Clément. 2009. Paramètres génétiques des caractéristiques de la semence de lapin. 13èmes Journ. Rech. Cunicole, Le Mans, France. 11:17-18.

Brun, J. M., M. Theau-Clément, and G. Bolet. 2002a. Evidence for heterosis and maternal effects on rabbit semen characteristics. Anim. Res. 51:433-442.

Brun, J. M., M. Theau-Clément, and G. Bolet. 2002b. The relationship between rabbit semen characteristics and reproductive performance after artificial insemination. Anim. Reprod. Sci. 70:139-149.

Brun, J. M., M. Theau-Clément, J. Esparbié, J. Falières, G. Saleil, and C. Larzul. 2006. Semen production in two rabbit lines divergently selected for 63-d body weight. Theriogenology 66:2165-2172.

Castellini, C., and P. Lattaioli. 1999. Effect of motile sperms inseminated on reproductive performance of rabbit does. Anim. Sci. 57:111-120.

Coffey, D. S. 1988. Androgen action and the sex accessory tissues. In: Physiology of reproduction, Knobill. E., Neill, J.D. (eds.), Raven Press, New York, 1081-119.

David, I., X. Druart, G. Lagriffoul, E. Manfredi, C. l. Robert-GraniÃ@), and L. Bodin. 2007. Genetic and environmental effects on semen traits in Lacaune and Manech tête rousse AI rams. Genet. Sel. Evol. 39:405-419.

Ducrocq, V., and P. Humblot. 1995. Genetic characteristics and evolution of semen production of young normande bulls. Livest. Prod. Sci. 41:1-10.

Falconer, D. S. 1965. The inheritance of liability to certain diseases, estimated from the incidence among relatives. Ann. Hum. Genet. 29:51-76.

Flowers, W. L. 2008. Genetic and phenotypic variation in reproductive traits of AI boars. Theriogenology 70:1297-1303. 
Furstoss, V., I. David, B. Leboeuf, P. Guillouet, P. Boue, and L. Bodin. 2009. Genetic and nongenetic parameters of several characteristics of production and semen quality in young bucks. Anim. Reprod. Sci. 110:25-36.

Garcia-Tomás, M., J. Sanchez, O. Rafel, J. Ramon, and M. Piles. 2006a. Reproductive performance of crossbred and purebred male rabbits. Livest. Sci. 104:233-243.

Garcia-Tomás, M., J. Sanchez, O. Rafel, J. Ramon, and M. Piles. 2006b. Variability, repeatability and phenotypic relationships of several characteristics of production and semen quality in rabbit. Anim. Reprod. Sci. 93:88-100.

Garcia-Tomás, M., J. Sanchez, O. Rafel, J. Ramon, and M. Plies. 2006c. Heterosis, direct and maternal genetic effects on semen quality traits of rabbits. Livestock Science 100:111-120.

Geweke, J. 1992. Evaluating the accuracy of sampling-based approaches to the calculation of posterior moments. Oxford Univ. Press, Oxford, UK.

Geyer, C. J. 1992. Practical markov chain monte carlo. Stat. Sci. 7:473-511.

Karoui, S., Díaz, C., Serrano, M., Cue, R., Celorrio, I.,Carabaño, M.J., Time trends, environmental factors and genetic basis of semen traits collected in Holstein bulls under commercial conditions, Anim. Reprod. Sci. (2010), doi:10.1016/j.anireprosci.2011.02.008

Khalil, M. H., K. A. Al-Sobayil, A. M. Al-Saef, M. L. García, and M. Baselga. 2007. Genetic evaluation for semen characteristics in a crossbreeding project involving Saudi and Spanish Vline rabbits. Animal 1:923-928.

Knights, S. A., R. L. Baker, D. Gianola, and J. B. Gibb. 1984. Estimates of heritabilities and of genetic and phenotypic correlations among growth and reproductive traits in yearling Angus bulls. J. Anim Sci. 58:887-893.

Larzul, C., and F. Gondret. 2005. Genetics of growth traits and meat quality in the rabbit. INRA Prod. Anim. 18(2):119-129.

Lavara, R., E. Moce, F. Lavara, M. P. V. de Castro, and J. S. Vicente. 2005. Do parameters of seminal quality correlate with the results of on-farm inseminations in rabbits? Theriogenology 64:1130-1141.

Lavara, R., J. S. Vicente, and M. Baselga. 2011. Genetic parameter estimates for semen production traits and growth rate of a paternal rabbit line. J. Anim. Breed. Genet. 128:44-51.

Legarra, A., L. Varona, and E. Lopez de Maturana. 2008. TM Threshold Model. Accessed Oct. 31, 2008. http://snp.toulouse. inra.fr/ alegarra/manualtm.pdf.

More O'Ferrall, G. J., and T. N. Meacham. 1968. Relationship between ph, other semen traits and fertility in rabbits. VI Cong. Intern. Reprod. Anim. Insem. Artif. Paris 2:1279-1281.

Morrell, J. M. 1995. Artificial insemination in rabbits. Br. Vet. J. 151:477-488.

Moura, A. S., M. Kaps, D. W. Vogt, and W. R. Lamberson. 1997. Two-way selection for daily gain and feed conversion in a composite rabbit population. J. Anim Sci. 75:2344-2349.

Oh, S. H., M. T. See, T. E. Long, and J. M. Galvin. 2006. Estimates of genetic correlations between production and semen traits in boar. Asian-Australasian J. Anim. Sci. 19:160-164.

Panella, F., C. Castellini, and E. Facchin. 1994. Heritability of some male reproductive traits in rabbit. Cah. Options Mediterr. 8:279-283.

Piles, M., E. A. Gomez, O. Rafel, J. Ramon, and A. Blasco. 2004. Elliptical selection experiment for the estimation of genetic parameters of the growth rate and feed conversion ratio in rabbits. J. Anim. Sci. 82:654-660.

Raftery, A. E., and S. Lewis (Editors). 1992. How many iterations in the gibbs sampler? Bayesian statistics 4. Oxford Univ. Press, NY. 
Rege, J. E. O., F. Toe, E. Mukasa-Mugerwa, S. Tembely, D. Anindo, R. L. Baker, and A. LahlouKassi. 2000. Reproductive characteristics of Ethiopian highland sheep: II. Genetic parameters of semen characteristics and their relationships with testicular measurements in ram lambs. Small Ruminant Res. 37:173-187.

ITAVI, 2008. Gestion technico-économique des éleveurs de lapins de chair (programmes RENACEB et RENALAP) Résultats 2008. Comité de pilotage de 10 de septembre 2009. http://www.itavi.asso.fr/economie/references/lapins.php.

Robinson, J. A. B., and M. M. Buhr. 2005. Impact of genetic selection on management of boar replacement. Theriogenology. 63:668-678.

Roca, J., S. Martinez, J. M. Vazquez, X. Lucas, I. Parrilla, and E. A. Martinez. 2000. Viability and fertility of rabbit spermatozoa diluted in Tris-buffer extenders and stored at 15 degrees C. Anim. Reprod. Sci. 64:103-112.

Rosell, J. M., and L. F. de la Fuente. 2009. Culling and mortality in breeding rabbits. Prev. Vet. Med. 88:120-127.

Smital, J., J. Wolf, and L. L. De Sousa. 2005. Estimation of genetic parameters of semen characteristics and reproductive traits in AI boars. Anim. Reprod. Sci. 86:119-130.

Sorensen, D., and D. Gianola. 2002. Likelihood, bayesian, and mcmc methods in quantitative genetics. . Springer Science and Business Media, LLC, New York, NY.

Theau-Clément, M., J. M. Brun, E. Sabbioni, C. Castellini, T. Renieri, U. Besenfelder, J. Falieres, J. Esparbie, and G. Saleil. 2003. Comparaison de la production spermatique de trois souches de lapins: Moyennes et variabilités. 10èmes Journ. Rech. Cunicole, Paris, France. 81-84.

Theau-Clément, M., A. Sanchez, and R. Duzert. 2009. Etude de facteurs de variation de la production spermatique chez le lapin. 13èmes Journées de la Recherche Cunicole. Le Mans. France.

Theau-Clément, M., and J. Falières. 2005. Evaluation de la concentration de semence de lapins selon 2 méthodes: Hématimètre et nucleocounter sp100. In Proc.: 11èmes Journées de la Recherche Cunicole. Paris. 95-99.

Tusell, L., A. Legarra, M. Garcia-Tomas, O. Rafel, J. Ramon, and M. Piles. 2010. Different ways to model biological relationships between fertility and the $\mathrm{pH}$ of the semen in rabbits J. Anim Sci. Accepted.

Vogt, D. W. 1979. Selection experiment with domestic rabbits. J. Hered. 70:421-422.

Wolf, J., and J. Smital. 2009. Quantification of factors affecting semen traits in artificial insemination boars from animal model analyses. J. Anim. Sci. 87:1620-1627.

Wolft, J. 2009. Genetic correlations between production and semen traits in pig. Animal 3:1094-1099.

Wright, S. 1934. An analysis of variability in number of digits in an inbred strain of guinea pigs. Genetics 19:0506-0536 


\section{Chapter two. Different ways to model}

\section{biological relationships between fertility and $\mathrm{pH}$ of the semen in rabbits}

L. Tusell, A. Legarra, M. Garcia-Tomás, O. Rafel, J. Ramon, and M. Piles

J. Anim. Sci. 2011. 89:1294-1303

This research was supported by Instituto Nacional de Investigacion y Tecnologia Agraria y Alimentaria (INIA, Madrid, Spain) project RTA2005-00088-CO2. Part of it was carried out during a visit by the first author to INRA, Toulouse. Llibertat Tusell Palomero received a fellowship from the INIA. The authors dedicate this work to Josep Terrades $\mathrm{i}$ Colom for his valuable cooperation with IRTA and his dedication and love of the rabbit industry during his life. The authors also thank Anna Perez, Carme Requena, and Oscar Perucho (Unitat de Cunicultura, IRTA, Caldes de Montbui, Barcelona, Spain), and Daniel Mozer Schonborn and Sinela Mozer Schonborn (Montmajor, Barcelona, Spain) for their invaluable cooperation during the experimental phase of this work and Rod Cantlay (Sant Feliu de Codines, Barce lona, Spain) and Jules Hernandez (Genetica i Millora Animal, IRTA, Lleida, Spain) for the English revision of the manuscript. 


\section{Abstract}

This work aimed to study the relationship between $\mathrm{pH}$ of the semen and fertility (Fert, de fined as the success or failure of conception), which is of special interest because $\mathrm{pH}$ of the semen can be considered a global marker of the expression of some seminal quality traits. Different methods used to model the relationship between Fert and $\mathrm{pH}$ are presented here: 1) ignoring genetic and environmental correlations and including $\mathrm{pH}$ either as a covariate or as a cross-classified effect on fertility, 2) a bivariate mixed model, and 3) recursive bivariate mixed models. A total of $653 \mathrm{pH}$ records and 6,365 Fert records after AI were used. Crossbreed does from 2 maternal lines were artificially inseminated with buck semen from a paternal line in a commercial environment. A negative, and almost linear, effect of $\mathrm{pH}$ on Fert was detected. The posterior median of $\mathrm{pH}$ and Fert heritabilities, and the highest posterior density interval at $95 \%$ (in parentheses) were approximately $0.18(0.05,0.29)$ and approximately $0.10(0.02$, 0.20 ) across all the models, respectively. Genetic correlations between traits were negative, but the highest posterior density interval at $95 \%$ included zero [i.e., $-0.31(-0.91,0.33)$ in the bivariate mixed model and $-0.17(-0.99,0.48)$ and $-0.44(-0.99,0.10)$ in the recursive bivariate mixed models including $\mathrm{pH}$ as a covariate or as a cross-classified effect, respectively]. All models predicted Fert data reasonably well (i.e., 76 and $62 \%$ correct predictions for success and failure, respectively). No differences in the prediction of the EBV for male fertility were encountered between models, showing a good concordance in the animals ranked by their EBV (the correlation between EBV in all models was close to 1). Thus, no differences in results were obtained considering, or not considering, genetic and environmental correlations between $\mathrm{pH}$ and Fert and assuming, or not assuming, recursiveness between each trait. This is because the magnitude of the effect of $\mathrm{pH}$ on Fert was not large enough; therefore, the same results were obtained even though the models were of different complexity.

Key words: (co)variance component, fertility, $\mathrm{pH}$ of semen, rabbit, recursive model 


\section{Introduction}

Male fertility (Fert) is one of the most economically interesting traits in rabbit breeding, especially with the use of AI (Alvariño, 2000). However, because of the low heritability of this trait in both natural and AI mating systems (Piles et al., 2005; Tusell et al., 2010), finding seminal quality traits to be used as criteria for indirect selection to increase male Fert has been paramount (More O'Ferrall and Meacham, 1968; Bencheikh, 1995; Brun et al., 2002; Lavara et al., 2005). The hydrogen-ion concentration in semen (pH) is a by-product of sperm metabolism associated with the number and activity of spermatozoids. Thus, it can be considered an indicator of seminal quality traits (More O'Ferrall and Meacham, 1968; Bencheikh, 1995); therefore, it is of special interest to determine its relationship to Fert.

Fertility and $\mathrm{pH}$ have a complex biological relationship. The $\mathrm{pH}$ of semen could affect the phenotypical expression of Fert but, contrary to some environmental effects (e.g., type of extender, AI technician, farm), pH is not an external effect of the animal, so, in turn, $\mathrm{pH}$ could also have genetic and permanent effects. Recursive models can accommodate this kind of biological relationship.

A recursive multitrait model is a particular case of structural equation models, which Gianola and Sorensen (2004) applied in a quantitative genetic context. These models are useful in describing biological relationships between traits that have simultaneity or recursiveness between their phenotypes, leading to a better interpretation of results. Gianola and Sorensen (2004) also pointed out that, in the presence of feedback and recursiveness, biased (co)variance estimates can be obtained if these relationships are not taken into account. Since then, several authors have been using these models to describe biological relationships between several traits in livestock species (de los Campos et al., 2006; Lopez de Maturana et al., 2007; Varona et al., 2007; Wu et al., 2008).

In this work, we studied the relationship between semen $\mathrm{pH}$ and male Fert by using different odels: 1) ignoring genetic and environmental correlations between each trait, 2) a classical multitrait model, and 3) recursive multitrait models. Models were compared according to their ability to predict Fert and the across-model EBV correlations. Ratios for genetic and environmental sources of variation were also estimated for both $\mathrm{pH}$ and Fert.

\section{Materials and methods}

The research protocol was approved by the animal care and use committee of the Institut de Recerca i Tecnologia Agroalimentaries. 


\section{Animals and Experimental Design}

Bucks came from the Caldes line, selected for growth rate during the fattening period (Gomez et al., 2002). They were bred and reared on an experimental farm from the Institut de Recerca i Tecnologia Agroalimentaries in Caldes de Montbui (Barcelona, Spain). After weaning at $32 \mathrm{~d}$, males were housed in cages of 8 individuals with a photoperiod of $16 \mathrm{~h}$ of light/d. Animals were fed a commercial diet ad libitum (15.5\% CP, 2.3\% fat, 17.2\% fiber; DM basis) until d 60 . After this period, they were individually housed and feed was restricted to $180 \mathrm{~g} / \mathrm{d}$ of another commercial diet (16\% CP, 4.3\% fat, 17\% fiber; DM basis). Fresh water was always available. All males began the training to an artificial vagina at 4.5 mo of age. One ejaculate per male and per week was collected for 2 wk. Their reproductive life began at 5 mo. At this age, 2 ejaculates per male and per week were collected, with an interval of $30 \mathrm{~min}$ between collections. From 5 to 9 mo of age, all males were evaluated at 3 different times for seminal quality traits and Fert score after AI of crossbred females on a commercial farm.

All semen evaluations and preparations of the AI doses were performed in a laboratory located beside the experimental farm of the Caldes line. Ejaculates were stored in a dry bath at $35^{\circ} \mathrm{C}$ until evaluation, for no more than $15 \mathrm{~min}$ after collection. Ejaculates containing urine and calcium carbonate deposits were discarded, and gel plugs were removed. Individual motility of the ejaculate was measured in aliquots $(25 \mu \mathrm{L})$ under a light microscope (Nikon, Lewisville, TX) at 400X magnification according to a subjective scale from 0 to $5(0,1,2,3,4$, or $5=0$ to $10,<10$ to $25,<25$ to $50,<50$ to $70,<70$ to 90 , or $<90$ to 100 , respectively, of the motile spermatozoa showing progressive movement). A small preselection of ejaculates was performed, discarding for AI only those with individual motility scores less than 2 and a percentage of dead spermatozoa greater than $50 \%$.

Semen pH was determined using a 507 Crison pH meter (Crison Instruments, SA, Barcelona, Spain). Preselecting good-quality ejaculates could have biased the sample. However, most of the rejections $(60.5 \%)$ were due to the presence of urine or calcium carbonate deposits from the bladder, which are not part of a normal ejaculate and could also affect the $\mathrm{pH}$ measurement. Semen was immediately prediluted 1:1 with a commercial extender (Cunigel, IMV Technologies France, L'Aigle, France). The semen from each buck obtained on the same day was pooled, and cell sperm concentration was measured by using a sperm cell counter (NucleoCounter SP-100, ChemoMetec A/S, Allerød, Denmark). The resultant pool was divided into 2 parts, which were diluted to $10 \times 10^{6}$ and $40 \times 10^{6}$ spermatozoa/mL, respectively, to obtain AI doses at 2 different sperm concentrations. Semen doses were stored in straws of 0.5 $\mathrm{mL}$ at $18^{\circ} \mathrm{C}$ for $24 \mathrm{~h}$ until their use.

Artificial insemination was performed on crossbred does [P $\times$ V; V line: Estany et al., 1989; P (Prat) line: Gómez et al., 1996] on a commercial farm. Females followed a semi-intensive 
reproductive rhythm: first mating at about 4.5 mo of age, with subsequent $42-\mathrm{d}$ reproductive cycles. All females were treated $48 \mathrm{~h}$ before AI with 15 IU of eCG (subcutaneously; Foligon, Intervet International B.V., Booxmeer, the Netherlands), and ovulation was induced immediately after AI with $0.02 \mathrm{mg}$ of gonadorelin (intermuscularly; Fertagyl, Intervet International B.V., Booxmeer, the Netherlands).

\section{Data}

Diagnosis of pregnancy was made by palpation, $14 \mathrm{~d}$ after AI, confirming the result at parity. The assigned Fert score was 1 when the female was diagnosed as pregnant and 0 otherwise. A total of 6,613 Fert records, involving 243 males and 2,293 females, were obtained between November 2006 and July 2007. Different Fert records had the same pH measurement. From the total amount of data, Fert records without a corresponding $\mathrm{pH}$ measurement were not included in the analysis, leading to a final figure of Fert data of 6,363. The pH was measured separately in each ejaculate and pooled whenever 2 ejaculates per male and day were obtained, as follows:

$$
p H=-\log _{10}\left[\left(10^{-p H_{1}} \times V_{o l} l_{1}+10^{-p H_{2}} \times V_{o l}\right) \times\left(V_{o l}+V_{1} l_{2}\right)^{-1}\right]
$$

where $\mathrm{pH}_{1}, \mathrm{Vol}_{1}, \mathrm{pH}_{2}$, and $\mathrm{Vol}_{2}$ are $\mathrm{pH}$ and volume measures for the first and the second ejaculate of the pool of each male, respectively. To increase the accuracy of the estimates concerning $\mathrm{pH}, 223 \mathrm{pH}$ data values without Fert results coming from 96 additional males were also incorporated into the analyses. These data were obtained between June 2006 and October 2006 as described above, but with the first and second ejaculate pooled before measuring $\mathrm{pH}$. Thus, from the final $653 \mathrm{pH}$ records, 490 had a paired Fert record.

\section{Model and Statistical Analysis}

Semen $\mathrm{pH}$ was assumed to be normally distributed and was analyzed jointly with Fert in a bivariate Gaussian-threshold model (Foulley et al., 1983). In a threshold model, the observed Fert $y_{\text {Fert }}$ is considered the expression of an underlying continuous variable $\mathrm{l}$, often called the liability (Falconer, 1965), which is rendered discrete by a fixed threshold that divides the observed response into 2 categories (Wright, 1934): the failure or the success of conception.

The probability that an observed Fert data value $\left(y_{i, \text { Fert }}\right)$ falls into 1 of these 2 categories given the liability is

$$
p\left(y_{i, F e r t} \mid l_{i}\right)=p\left(l_{i}>0\right) I\left(y_{i, F e r t}=1\right)+p\left(l_{i} \leq 0\right) I\left(y_{i, F e r t}=0\right)
$$


The threshold being fixed at $0, I($.$) is an indicator function that takes the value of 1$ or 0 .

A bivariate recursive model postulates that trait 1 has an effect on trait 2, but that trait 2 has no effect on trait 1 . In the case of recursiveness (but not for simultaneity), the model presented by Gianola and Sorensen (2004) can be expressed as a classical multitrait model in which trait 1 is included as a systematic effect in the model for trait 2 (López de Maturana et al., 2007). In this work, $\mathrm{pH}$ is trait 1 and Fert is trait 2. Thus, in our case, the jth pair of records for an individual i had the following linear relationship:

$$
\begin{aligned}
& \left(\begin{array}{l}
y_{i j, p H} \\
l_{i j, F e r t}
\end{array}\right)=\left(\begin{array}{cc}
\mathbf{x}_{i j, p H}^{\prime} & 0 \\
0 & \mathbf{x}_{i j, \text { Fert }}^{\prime}
\end{array}\right)\left(\begin{array}{l}
\boldsymbol{\beta}_{p H} \\
\boldsymbol{\beta}_{\text {Fert }}
\end{array}\right)+\left(\begin{array}{cc}
0 & 0 \\
0 & y_{i j, p H}
\end{array}\right)\left(\begin{array}{c}
0 \\
\lambda_{\text {Fert } \leftarrow p H}
\end{array}\right) \\
& +\left(\begin{array}{l}
u_{i, p H} \\
u_{i, F e r t}
\end{array}\right)+\left(\begin{array}{l}
p m_{i, p H} \\
p m_{i, F e r t}
\end{array}\right)+\left(\begin{array}{c}
0 \\
p f_{m, F e r t}
\end{array}\right)+\left(\begin{array}{l}
p m d_{i j, p H} \\
p m d_{i j, F e r t}
\end{array}\right)+\left(\begin{array}{l}
e_{i j, p H} \\
e_{i j, F e r t}
\end{array}\right)
\end{aligned}
$$

The coefficient $\lambda_{\text {Fert } \leftarrow p H}$ denotes the phenotypical rate of change of the liability of Fert with respect to $\mathrm{pH}$, i.e., models the recursive effect of $\mathrm{pH}$ on Fert. The different $\lambda_{\text {Fert } \leftarrow p H}$ assumed in the models were always estimated as systematic effects in equation (1). The $y_{i j, p H}$ and $l_{i j, F e r t}$ were the $j$ th data value for the observed $\mathrm{pH}$ and the unobserved liability for male $i$. Term $\boldsymbol{\beta}_{p H}$ was the vector of systematic effects affecting $\mathrm{pH}$, including day of ejaculate collection $(27$ levels) and male age ( 4 levels at about 1 mo intervals from 5 mo to 9 mo old). The term $\boldsymbol{\beta}_{\text {Fert }}$ was the vector of systematic effects for Fert, including concentration of the AI dose (2 levels: 10 or 40 million of spermatozoa per $\mathrm{mL}$ ), physiological status of the female (3 levels: nulliparous does, multiparous does in lactation and multiparous does not in lactation at AI), a combined effect between day and inseminator (19 levels at $14 \mathrm{~d}$ intervals between November 2006 and July 2007), and a combined effect between the age of the male and the building (9 levels, about 1 mo intervals from 5 mo until 9 mo of age combined with the two buildings of the commercial farm where AI was performed). The term $\mathbf{x}_{i j, k}$ ( $\left.k=p H, F e r t\right)$ was the corresponding row of an incidence matrix relating data with systematic effects. The $u_{i, k}$ was the male genetic additive effect, $p m_{i, k}$ was the male permanent environmental effect, $p f_{m, \text { Fert }}$ was the $m$ th female effect for Fert trait, $p m d_{i j, k}$ was the environmental permanent effect resulting from the combination between male and day of AI and, finally, $e_{i j, k}$ was the random residual effect. Note that for the $\mathrm{pH}, p m d_{i j, p H}$ is also a residual component and it can be 
separated from the residual only because it is related to the $p m d_{i j, F e r t}$ of the Fert model. This residual decomposition increases the data connectivity and permits the estimation of a possible environmental correlation between the traits.

A Bayesian approach was adopted for inference. Note that

$\boldsymbol{\Omega}=\left\{\boldsymbol{\beta}, \lambda_{\text {Fert } \leftarrow p H}, \mathbf{u}, \mathbf{p}_{\mathbf{m}}, \mathbf{p}_{\mathbf{f}}, \mathbf{p}_{\mathbf{m d}}, \mathbf{G}, \mathbf{P}_{\mathbf{m}}, \mathbf{P}_{\mathbf{f}}, \mathbf{P}_{\mathbf{m d}}, \mathbf{R}\right\}$ is the vector including all the unknown parameters in the model. The term $\boldsymbol{\beta}$ is the vector of systematic effects, $\mathbf{u}_{\mathrm{m}}$ is the vector of male genetic additive effects, $\mathbf{p}_{\mathbf{m}}$ is the vector of the male non-additive genetic plus permanent environmental effects, $\mathbf{p}_{\mathbf{f}}$ is the vector of the female effects, $\mathbf{p}_{\mathbf{m d}}$ is the vector of the permanent environmental effects resulting from the combination between the male and the day on which the AI was performed. The terms $\mathbf{G}, \mathbf{P}_{\mathbf{m}}, \mathbf{P}_{\mathbf{f}}, \mathbf{P}_{\mathbf{m d}}$ are the different (co)variance matrices of the corresponding random effects defined above and $\mathbf{R}$ is the residual (co)variance matrix. The joint posterior distribution of all parameters was:

$$
\begin{aligned}
& p\left(\mathbf{\Omega}, \mathbf{l} \mid \mathbf{y}_{p H}, \mathbf{y}_{\text {Fert }}\right) \propto p\left(\mathbf{y}_{p H} \mid \mathbf{\Omega}\right) \times \\
& \prod_{i=1}^{n}\left\{p\left(l_{i}>0\right) I\left(y_{i}=1\right)+p\left(l_{i} \leq 0\right) I\left(y_{i}=0\right)\right\} \times p(\mathbf{l} \mid \mathbf{\Omega}) \times p(\mathbf{\Omega})
\end{aligned}
$$

The prior distributions for the parameters of the model were:

$$
\begin{aligned}
& p(\boldsymbol{\beta}) \sim k ; p\left(\mathbf{u}_{m} \mid \mathbf{G}\right) \sim N(\mathbf{0}, \mathbf{A} \otimes \mathbf{G}) ; p\left(\mathbf{p}_{m} \mid \mathbf{P}_{m}\right) \sim N\left(\mathbf{0}, \mathbf{I} \otimes \mathbf{P}_{m}\right) ; \\
& p\left(\mathbf{p}_{f} \mid \mathbf{P}_{f}\right) \sim N\left(\mathbf{0}, \mathbf{I} \otimes \mathbf{P}_{f}\right) ; p\left(\mathbf{p}_{m d} \mid \mathbf{P}_{m d}\right) \sim N\left(\mathbf{0}, \mathbf{I} \otimes \mathbf{P}_{m d}\right) ; \\
& p(\mathbf{e} \mid \mathbf{R}) \sim N(\mathbf{0}, \mathbf{I} \otimes \mathbf{R})
\end{aligned}
$$

where $k$ is a constant and $\mathbf{A}$ is the numerator relationship matrix. Bounded uniform prior distributions were assumed for $\boldsymbol{\beta}, \lambda_{\text {Fert } \leftarrow p H}$ and the components of $\mathbf{G}, \mathbf{P}_{\mathbf{m}}, \mathbf{P}_{\mathbf{f}}, \mathbf{P}_{\mathbf{m d}}$ and $\mathbf{R}$. The $\mathbf{R}$ was a diagonal matrix with the residual variance for Fert set to 1. Data augmentation was used to deal with the missing Fert data (Sorensen and Gianola, 2002).

Three sets of models to describe the $\mathrm{pH}$ and Fert relationship were used. Within each model, different types of $\lambda_{\text {Fert } \leftarrow p H}$ were assumed, i.e. null, covariate or cross-classified effect, in order to accommodate null, linear and non-linear recursive effects (López de Maturana et al., 2009) of $\mathrm{pH}$ on Fert. Table 2.1 shows the summary statistics for the different levels of $\lambda_{F e r t \leftarrow p H}$ as a cross-classified effect in the Fert model. 
Table 2.1. Summary statistics of the cross-classified effect of pH ( 1 to 8 ) included in the fertility model

\begin{tabular}{lcccccccc}
\hline Item & 1 & 2 & 3 & 4 & 5 & 6 & 7 & 8 \\
\hline Range & $\leq 7$ & $(>7$, & $(>7.13$, & $(>7.25$, & $(>7.38$, & $(>7.5$, & $(>7.75$, & $(>8$, \\
$\begin{array}{l}\text { Mean } \\
\begin{array}{l}\text { No. of } \\
\text { fertility }\end{array}\end{array}$ & 7.80 & 7.06 & 7.19 & 7.31 & 7.44 & 7.60 & 7.88 & 8.21 \\
records & 796 & 710 & 915 & 1,074 & 881 & 1,001 & 601 & 387 \\
\hline
\end{tabular}

\section{Univariate Mixed Models}

In these models, the genetic and environmental correlations between each trait were set to zero. This implies that the phenotypic recursion is the only cause of correlation between any of the random effects (López de Maturana et al., 2010). The effect of pH on Fertility ( $\lambda_{\text {Fert } \leftarrow p H}$ ) was estimated as a covariate in $\mathbf{U M M}_{\text {cov }}$ model or as a cross-classified effect of eight categories (as described in Table 2.1) in $\mathbf{U M M}_{\text {cross }}$ model.

\section{Bivariate Mixed Model}

The two traits were genetically and environmentally correlated. In $\mathbf{B M M}_{\mathbf{0}}$ model, the genetic and environmental relationships between each trait were accounted for by the covariances and no recursive effect was assumed $\left(\lambda_{\text {Fert } \leftarrow p H}=0\right)$.

\section{Bivariate Recursive Mixed Models}

In order to take into account the phenotypical influence of $\mathrm{pH}$ on Fert, and also the genetic and environmental relationships between each trait, two recursive Gaussian-threshold models were proposed. First, model $\mathbf{R} \mathbf{M M}_{\text {cov }}$ had $\lambda_{F e r t<H}$ as a covariate. Some identification problems appeared in this model. Because the $\mathrm{p}_{\mathrm{md}}$ effect is also a residual component in the $\mathrm{pH}$ model, the restriction that $\mathbf{P}_{\mathrm{md}}$ was diagonal was added to ensure likelihood identification (Varona et al., 2007). Second, model $\mathbf{R M M}_{\text {cross }}$ had $\lambda_{\text {Fert } \leftarrow p H}$ as a cross-classified effect of eight categories (as described in Table 2.1).

Table 2.2 shows the type of structural coefficient $\lambda_{\text {Fert } \leftarrow p H}$ and the structure of the (co)variance component matrices used in each of the models. 
Table 2.2. Structural coefficients $\left(\lambda_{\text {Fert } \leftarrow \text { HH}}\right.$ ) and (co)variance component matrices for the male additive effects (G), the male nonadditive plus environmental permanent effects ( $\boldsymbol{P}_{\mathrm{m}}$ ), the female effects $\left(\mathbf{P}_{\mathbf{f}}\right)$, the permanent environmental effects of male and day of AI ( $\boldsymbol{P}_{\mathrm{md}}$ ), and the residual effects ( $\mathbf{R})$ for $\mathrm{pH}$ of the semen and fertility (Fert) assumed in the different models ${ }^{1}$

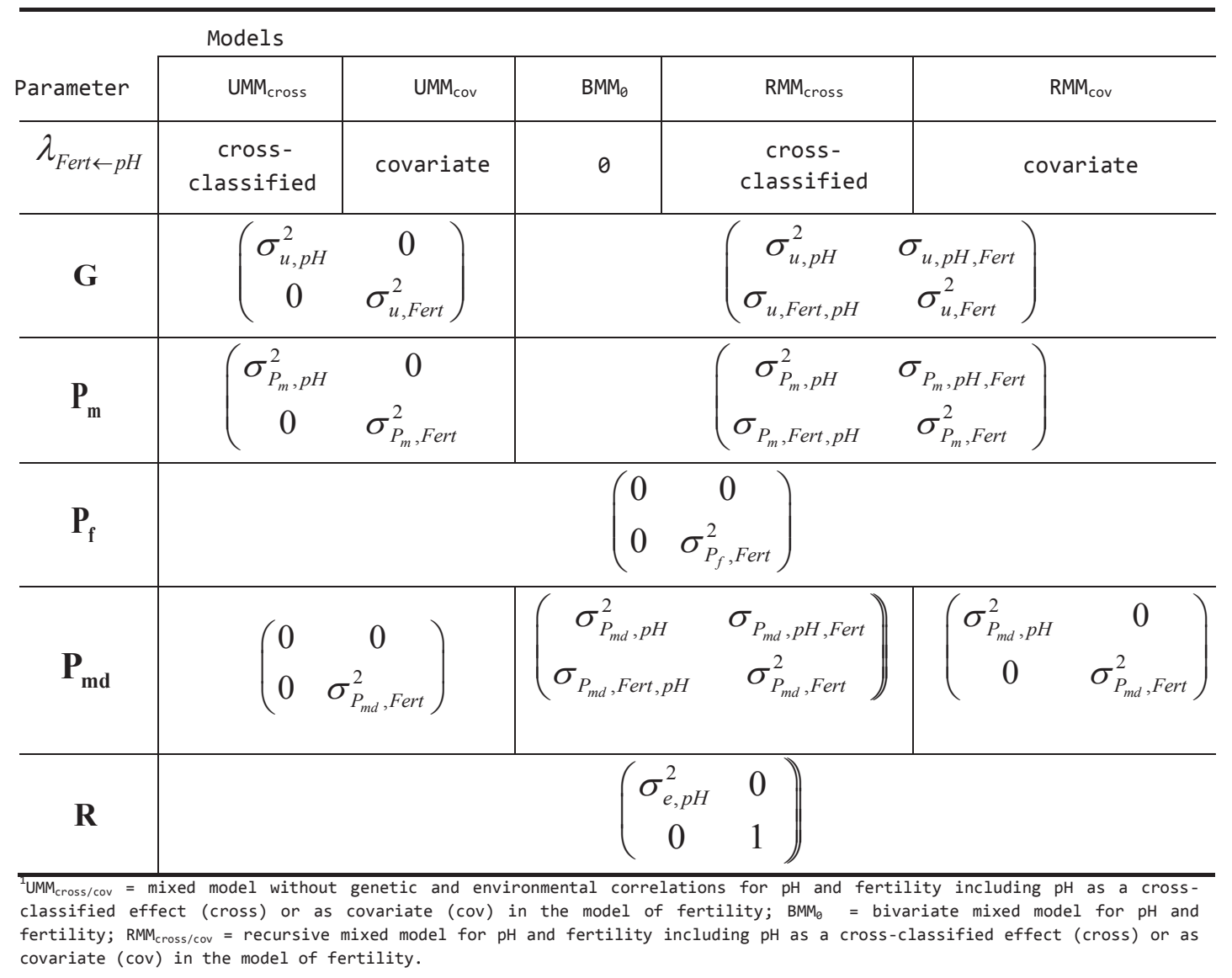

\section{The Gibbs sampler}

Procedures developed by Sorensen et al. (1995) and extensions of them, based on Markov Chain Monte Carlo methods, allow the univariate and joint analysis of categorical and continuous traits. Marginal posterior distributions of the parameters of interest were approximated using the Gibbs sampler algorithm (using the TM software developed by Legarra et al. 2008). Fully conditional posterior distributions of the model parameters needed for the implementation of this algorithm can be found in Sorensen and Gianola (2002). Single chains of 500,000 iterations were run for all the models, discarding the first 50,000 iterations of each chain and saving 1 of every 10 samples. The number of samples discarded in the burnin was, in all the analyses, much larger than the value recommended by Raftery and Lewis (1992) and Geweke (1992) for assessing convergence. The sampling variance of the chains was obtained by computing Monte Carlo standard errors (Geyer, 1992). 
Recursive model as an alternative parameterization of a classical bivariate model

Following Varona et al. (2007) a recursive model can have an equivalent parameterization in a classical bivariate model. This equivalence is as follows:

\section{$\boldsymbol{\Lambda}^{-1} \mathbf{H}^{*}\left(\boldsymbol{\Lambda}^{-1}\right)^{\prime}=\mathbf{H}$}

where $\boldsymbol{\Lambda}=\left(\begin{array}{cc}1 & 0 \\ -\lambda_{F e r \leftarrow<p H} & 1\end{array}\right)$ is the matrix of structural coefficients, and $\mathbf{H}^{*}$ and $\mathbf{H}$ are the different (co)variance components of the recursive and the bivariate mixed model, respectively. In our study, $\mathbf{H}$ corresponded to the $\mathbf{G}, \mathbf{P}_{\mathbf{m}}, \mathbf{P}_{\mathbf{f}}, \mathbf{P}_{\mathbf{m d}}, \mathbf{R}$ described above and this equivalence was assessed between $\mathrm{RMM}_{\mathrm{cov}}$ and $\mathrm{BMM}_{0}$ models.

\section{Data prediction ability and EBV comparison}

Posterior predictive distribution of Fert data was calculated in all the models.

Thus, the ability to predict success or failure in each Fert record was averaged as follows:

$$
E\left(\hat{\mathbf{y}}_{\text {Fert }} \mid \mathbf{y}_{\text {Fert }}, \mathbf{\Omega}, \mathbf{l}, M\right)=\frac{1}{n} \sum_{i=1}^{n}\left(\hat{\mathbf{y}}_{\text {Fert }, i} \mid \mathbf{y}_{\text {Fert }}, \mathbf{\Omega}_{i}, \mathbf{l}_{i}, M\right)
$$

where $\hat{\mathbf{y}}_{\text {Fert }}$ is the vector of predicted data on the observed scale, $\mathbf{y}_{\text {Fert }}$ the observed fertility data, $\boldsymbol{\Omega}$ the vector of unknown parameters, $\mathbf{l}$ the vector of liabilities, $M$ the model used and $n$ the total number of iterations. Each predicted Fert value was assumed to be correct when the absolute value of the difference between the observed Fert and the posterior mean (PM) of the posterior distribution did not differ more than 0.25 . Thus, good fertility record prediction was achieved when the probability of correctly predicting the record was $\geq 75 \%$.

$y_{\text {Fert }, i}-E\left(\hat{y}_{\text {Fert }, i} \mid \mathbf{y}_{\text {Fert },-i}, \mathbf{\Omega}, \mathbf{l}, M\right) \leq 0.25$

Correlations between the posterior means of the EBV for Fert obtained in the models were calculated to evaluate possible differences in the estimation of male additive genetic effects. The average EBV of the top 10\% animals was also calculated in each of the models. 


\section{Results and discussion}

The average semen pH was 7.43 (s.d. 0.42), well within the range of values obtained previously in the same line and in other rabbit breeds (Bencheikh, 1995; Brun et al., 2002; Garcia-Tomás et al., 2006b, Brun et al., 2009). The current fertility (52\%) was lower than had been previously observed in the nucleus of selection of this paternal line over purebred females using either natural mating (86.2\%; Piles et al., 2005) or AI (71.7\%, Tusell et al. 2010). The AI conditions of this experiment (lower sperm dosage and $24 \mathrm{~h}$ of storage period of the doses before $\mathrm{AI}$ in a commercial farm over crossbred females) could be more unfavorable than natural mating conditions and the AI conditions in the nucleus of selection over purebred females (high sperm dosage, no storage period). To our knowledge, there is only one published research work reporting fertility results after AI using homospermic doses (Brun et al., 2002). After rejecting a larger number of ejaculates, Brun et al. (2002) obtained similar fertility rates (ranging from $49.4 \%$ to $63.6 \%$ in two purebred lines and their reciprocal crosses). However, female receptivity was not artificially induced and could contribute to lowering fertility even after strong sperm quality selection.

\section{Effect of structural coefficients of pH on Fertility}

Table 2.3 shows the estimates in the liability scale of the $\lambda_{\text {Fert } \leftarrow p H}$ effects in each model.

Table 2.3. Means (SD) of the posterior distributions of the recursive effect of the $\mathrm{pH}$ in the liability of fertility with $\lambda$ and $\lambda_{i}$ (for $i=1, \ldots 8$ ) a covariate or as a cross-classified effect

\begin{tabular}{|c|c|c|c|c|c|c|c|c|c|}
\hline Model $^{1}$ & $\lambda$ & $\lambda_{1}$ & $\lambda_{2}$ & $\lambda_{3}$ & $\lambda_{4}$ & $\lambda_{5}$ & $\lambda_{6}$ & $\lambda_{7}$ & $\lambda_{8}$ \\
\hline $\mathrm{UMM}_{\text {cross }}$ & - & $\begin{array}{c}0.42 \\
(0.16)\end{array}$ & $\begin{array}{c}0.17 \\
(0.15)\end{array}$ & $\begin{array}{c}0.08 \\
(0.14)\end{array}$ & $\begin{array}{c}-0.03 \\
(0.15)\end{array}$ & $\begin{array}{c}-0.09 \\
(0.14)\end{array}$ & $\begin{array}{c}-0.41 \\
(0.16)\end{array}$ & $\begin{array}{c}-0.49 \\
(0.19)\end{array}$ & $\begin{array}{c}0.08 \\
(0.14)\end{array}$ \\
\hline $\mathrm{UMM}_{\mathrm{cov}}$ & $\begin{array}{c}-0.63 \\
(0.11)\end{array}$ & - & - & - & - & - & - & - & - \\
\hline $\mathrm{RMM}_{\text {cross }}$ & - & $\begin{array}{c}0.19 \\
(0.21)\end{array}$ & $\begin{array}{c}0.14 \\
(0.18)\end{array}$ & $\begin{array}{c}0.07 \\
(0.16)\end{array}$ & $\begin{array}{c}0.03 \\
(0.14)\end{array}$ & $\begin{array}{c}-0.02 \\
(0.15)\end{array}$ & $\begin{array}{c}-0.01 \\
(0.15)\end{array}$ & $\begin{array}{c}-0.25 \\
(0.20)\end{array}$ & $\begin{array}{c}-0.19 \\
(0.28)\end{array}$ \\
\hline $\mathrm{RMM}_{\mathrm{cov}}$ & $\begin{array}{c}-0.15 \\
(0.07)\end{array}$ & - & - & - & - & - & - & - & - \\
\hline
\end{tabular}

(xed model for $\mathrm{pH}$ and fertility without genetic and environmental correlations including $\mathrm{pH}$ as a cross fertility including $\mathrm{pH}$ as a cross-classified effect (cross) or as covariate (cov) in the model of fertility.

Estimates of each level within each cross-classified effect $\lambda_{\text {Fert } \leftarrow p H}$ were obtained as deviations from the estimated marginal posterior distribution (EMPD) of the mean Fert liability. Transformations from the underlying scale to the observed scale of the effects of the structural coefficients on Fert are plotted in Figure 2.1. The estimated values of $\lambda_{\text {Fert } \leftarrow p H}$ as a covariate or as a cross-classified effect were consistent across all the models indicating that an increase in $\mathrm{pH}$ leads to a decrease in Fert and this relation seems to be almost lineal. The recursive models were the ones that had a shallower slope in this decrease, probably because part of the $\mathrm{pH}$ effect got included in the covariances between the random effects of the traits. 
The observed negative relationship between $\mathrm{pH}$ and Fert agrees with previous studies that evidenced negative correlation between the $\mathrm{pH}$ of the ejaculate and fertility (Coffey, 1988; Brun et al., 2002) and also with litter size (More O'Ferrall and Meacham, 1968). The higher the concentration and motility of spermatozoids in ejaculates, the lower the $\mathrm{pH}$ due to a greater production of lactic acid (Coffey, 1988;Hulet and Ercanbrack, 1962; Bencheikh, 1995; Brun et al., 2002; Garcia-Tomás et al., 2006a). Thus, pH can be an indicator of semen quality, offering to AI centers an easy way to select ejaculates and males for AI in order to improve fertility.

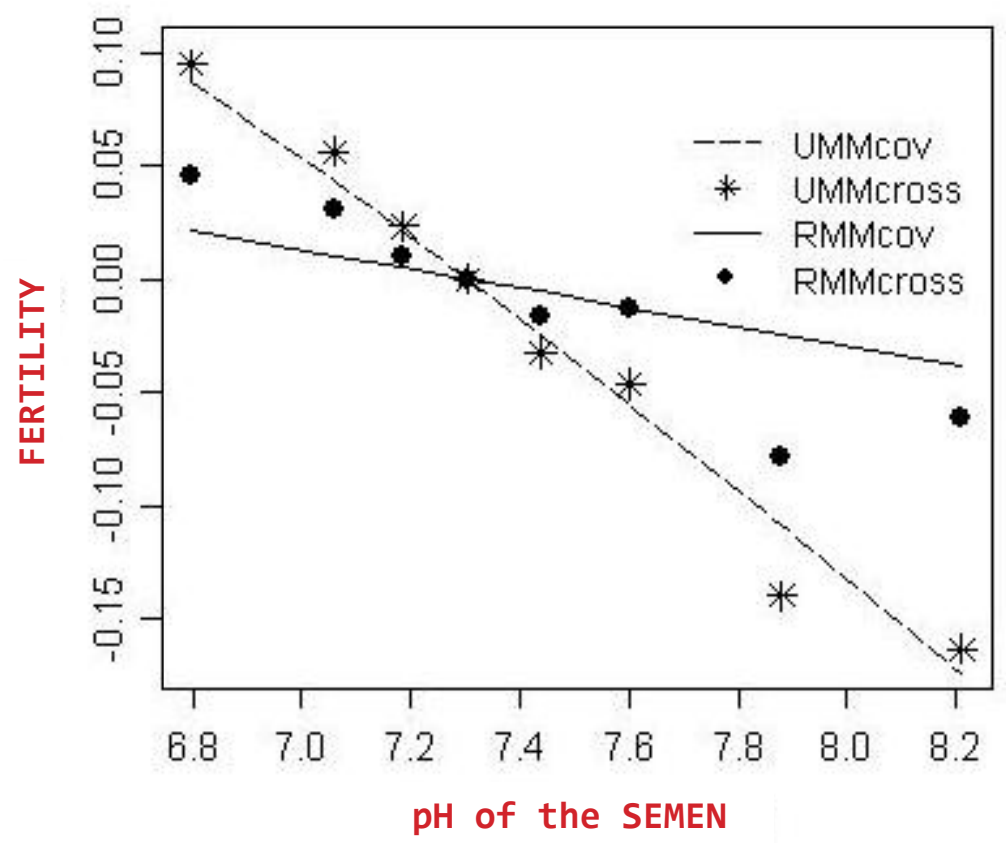

Figure 2.1. Effect of $\mathrm{pH}$ on fertility on the observed scale in the different models for $\mathrm{pH}$ of the semen and fertility: a mixed model without genetic and environmental correlations including $\mathrm{pH}$ as a covariate or as cross-classified effect in the model of fertility (models $\mathrm{UMM}_{\text {cov }}$ and $\mathrm{UMM}_{\text {cross, }}$ respectively), and recursive mixed model including $\mathrm{pH}$ as a covariate or as a cross-classified effect in the model of fertility (RMMcross and RMMcross, respectively).

Although the relationship between $\mathrm{pH}$ and Fert is almost linear, the inclusion of $\lambda_{\text {Fert } \leftarrow p H}$ as a cross-classified effect allows checking nonlinearity without apparent loss of accuracy or computing problems.

\section{(Co)variance components}

Table 2.4 shows features of the posterior distributions of phenotypic variances, ratios of variances and correlations between traits 


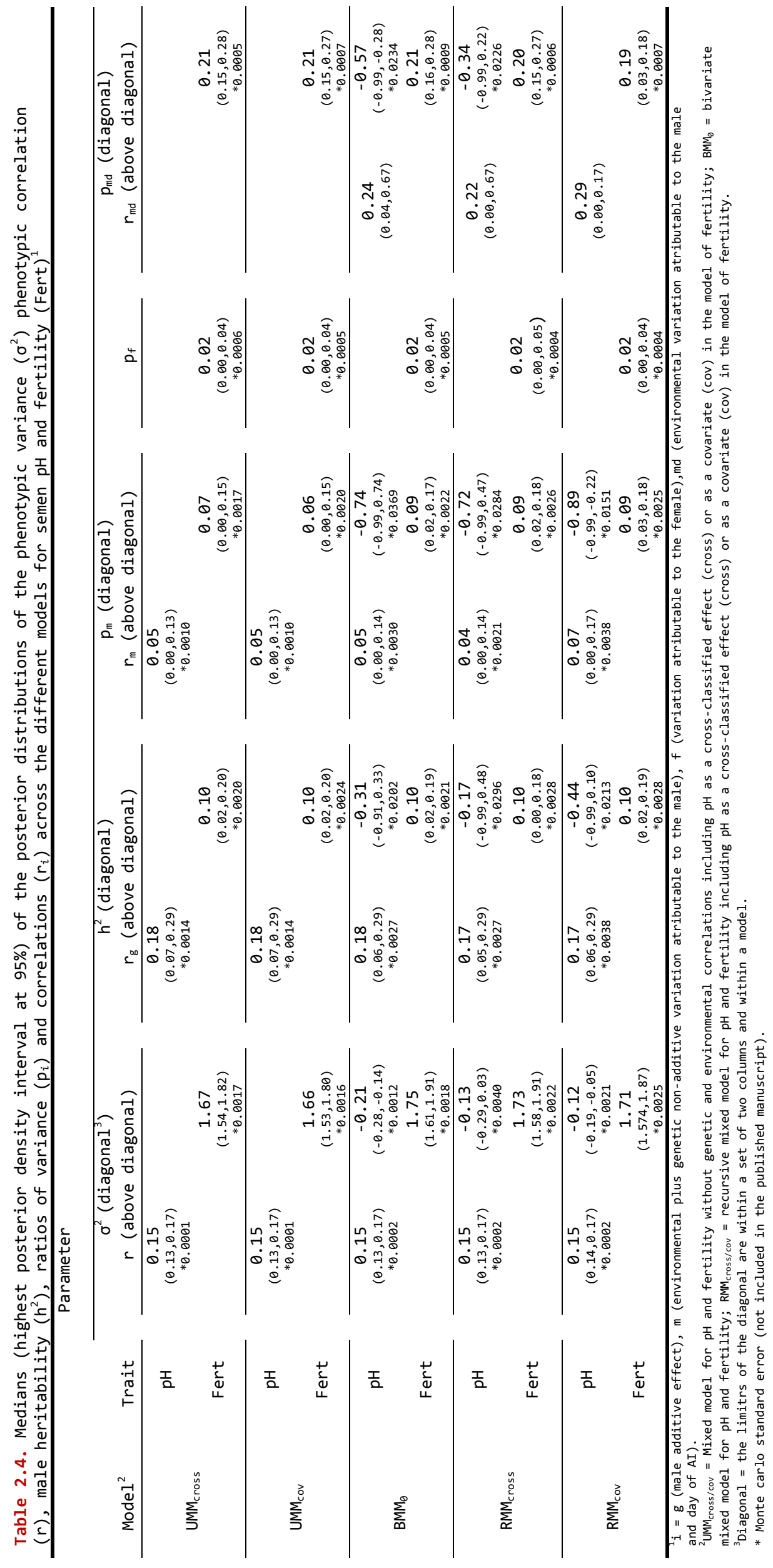


The posterior median of $\mathrm{pH}$ heritability $\left(\mathbf{h}^{2}\right)$ was equal in all the models (0.18) but higher than had been previously reported (Brun et al. 2009). The posterior median of the pH repeatability $\left(\mathbf{r}_{\mathbf{p H}}\right)$ was $\sim 0.23$ with highest posterior probability density interval at 95\% (HPD $\left.{ }_{95 \%}\right) \sim[0.13$, $0.34]$ in the models presented. Previous studies in rabbits showed similar values of $\mathrm{r}_{\mathrm{pH}}: 0.07-$ 0.24 by Bencheikh (1995) who compared between groups with different frequencies of ejaculate extraction; and, 0.17 by Brun et al. (2009). Garcia-Tomás et al. (2006a) obtained a $\mathrm{r}_{\mathrm{pH}}$ of 0.38 in two paternal lines of rabbits (one of them being the Caldes line) and its reciprocal crosses.

The posterior median of $\mathrm{h}^{2}$ for male Fert was 0.10 and its repeatability ( $\mathbf{r}_{\text {Fert }}$ ) was $\sim 0.19$ with $\mathrm{HPD}_{95 \%} \sim[0.12,0.26]$ across all the models. Both estimates were higher than had been previously reported $\left(\mathrm{HPD}_{95 \%}\right.$ of $\mathrm{h}^{2}=[0.004,0.024], \mathrm{r}_{\mathrm{Fert}}=0.044$; Piles et al., 2005). The probability of $\mathrm{h}^{2}>0.02$ was greater than $96 \%$ in all the models. The AI procedure used in this work (stringent ejaculate selection, less spermatic concentration and use of the doses after a storage period) were probably optimal to detect fertility differences between males (Amman and Hammerstedt 2002). This fact could lead obtaining a higher genetic variability of this trait than the one obtained after natural mating. This is probably due to the observation of other genetic effects in underlying fertility that are masked in optimal conditions of AI or after natural mating (Tusell et al., 2010).

Biased trait parameters could be obtained if the selection criterion (growth rate) is correlated with the analyzed traits (Gianola and Fernando, 1986). To our knowledge, these correlations have not been estimated. Nevertheless, genetic correlation between female fertility and growth rate was low (-0.13; Tusell et al. 2009). Since the genetic correlation for male and female fertility seems to be positive in this line (Piles et al., 2005), it is expected that the genetic correlation between male fertility and growth rate is negligible too.

Although estimates were very imprecise, the posterior median of genetic correlation $\left(\mathbf{r}_{\mathbf{g}}\right)$ between $\mathrm{pH}$ and Fert was moderately negative in all the models, i.e. $\mathrm{P}\left(\mathrm{r}_{\mathrm{g}}<0\right)$ of $0.83,0.68$ and 0.91 for $\mathrm{BMM}_{0}, \mathrm{RMM}_{\text {cov, }}$ and $\mathrm{RMM}_{\text {cross, }}$, respectively. The semen $\mathrm{pH}$ is also genetically correlated with several motility parameters which, in turn, are related to fertility (Brun et al., 2002; 2009).

Recursive model as an alternative parameterization of a classical bivariate model

Following Varona et al. (2007), the expression which defines the equivalence for the phenotypic (co)variance components between a recursive and a classical bivariate model is $\Lambda_{\text {RMM }_{\text {cov }}}^{-1}\left(\mathbf{V}_{\text {RMM }_{\text {cov }}}\right)\left(\Lambda_{\text {RMM }_{\text {cov }}}^{-1}\right)^{\prime}=\mathbf{V}_{\text {BMM }_{0}}$. The matrix of structural coefficients containing the 
regression coefficient of pH on Fert is $\boldsymbol{\Lambda}_{\mathrm{RMMcov}}=\left(\begin{array}{cc}1 & 0 \\ -0.15(0.07) & 1\end{array}\right)$ (Table 2.3, $\mathrm{RMM}_{\text {cov }}$ model). The term $\mathbf{V}_{\text {RMM }_{\text {cov }}}$ denotes the phenotypic (co)variance matrix estimated with model $\mathrm{RMM}_{\mathrm{cov}}$ (Table 2.4), and therefore

$\boldsymbol{\Lambda}_{\mathrm{RMM}_{\mathrm{cov}}}^{-1}\left(\mathbf{V}_{\text {RMM }_{\text {cov }}}\right)\left(\boldsymbol{\Lambda}_{\mathrm{RMM}_{\mathrm{cov}}}^{-1}\right)^{\prime}=\left(\begin{array}{cc}0.15(0.01) & -0.08(0.02) \\ -0.08(0.02) & 1.74(0.08)\end{array}\right)$. These values are almost equal to the phenotypic (co)variance matrix obtained with $\mathrm{BMM}_{0}$ model: $\mathbf{V}_{\text {BMм }_{0}}=\left(\begin{array}{cc}0.15(0.01) & -0.11(0.02) \\ -0.11(0.02) & 1.76(0.08)\end{array}\right)$.

\section{Model comparison}

The ability to predict fertility data was similar across all the models: $76 \%$ of correctly predicted successes and $62 \%$ of correctly predicted failures.

Figure 2.2 shows the histograms of the mean of posterior predictive distributions for success and failure fertility data estimated using models $\mathrm{UMM}_{\text {cov }}, \mathrm{BMM}_{0}$ and $\mathrm{RMM}_{\text {cross. }}$

Correlations between posterior means of the EBV for male fertility across models were close to 1 . No differences were encountered in the average EBV of the top $10 \%$ animals among the models. Thus, after performing a truncated selection of the best $10 \%$ ranked by its EBV, the same the genetic gain would be obtained by using any of the models studied.

The highest correlations were between models that only differed in the type of $\lambda_{\text {Fert } \leftarrow p H}$ included in the model (covariate or cross-classified effect) confirming the linear effect of $\mathrm{pH}$ on Fert.

Despite differing in complexity, models did not differ in terms of fertility predictions. This is due by both the imprecision of parameters estimation and the low magnitude of those parameters. 

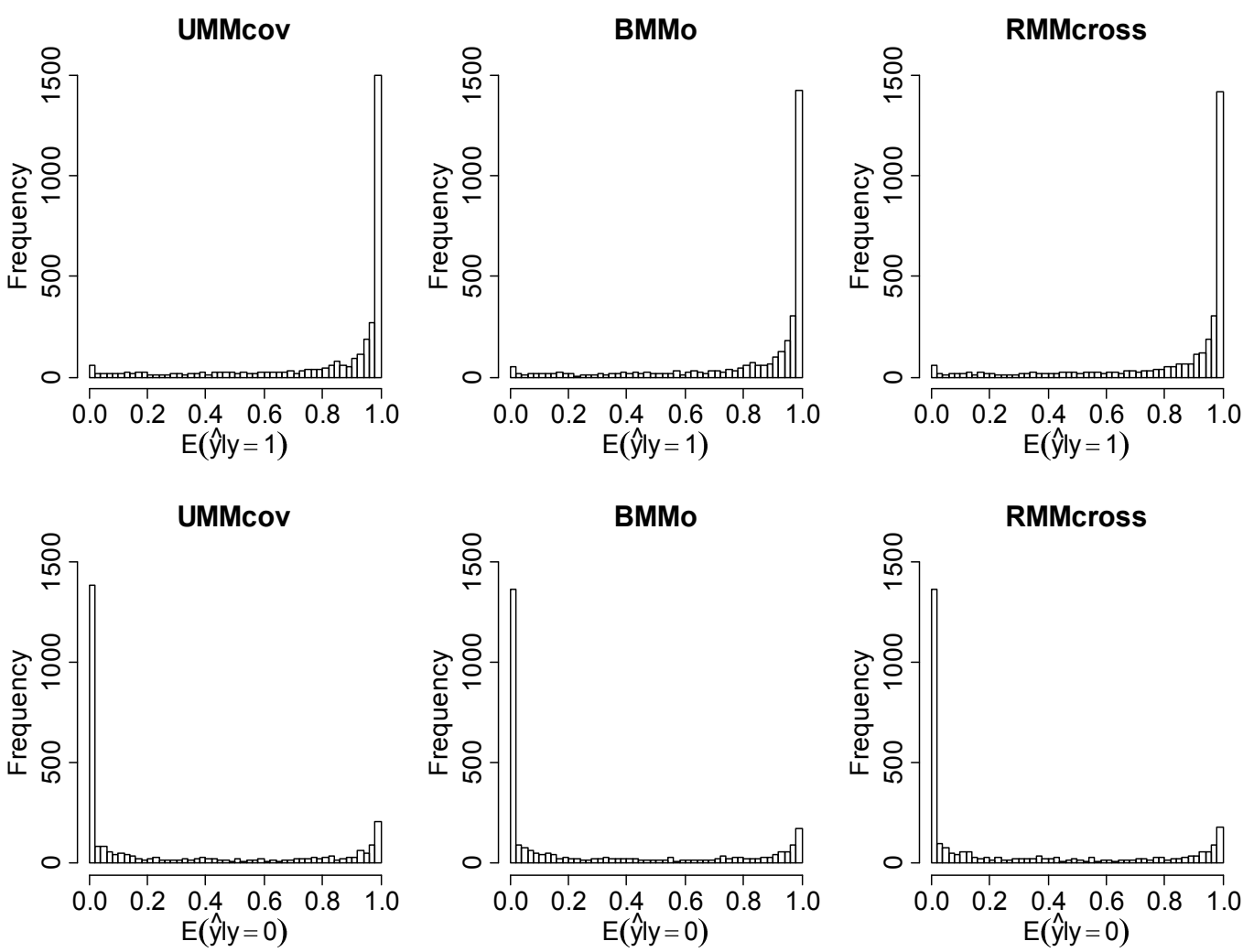

Figure 2.2. Posterior predictive distributions of the mean of a fertility success [E( $\hat{y}$ ] $y=1)]$ and the mean of a fertility failure $[E(\hat{y} \mid y=0)]$ estimated in the following models for fertility and $\mathrm{pH}$ of the semen: a mixed model without genetic and environmental correlations including $\mathrm{pH}$ as a covariate in the model of fertility (model $U \mathbf{M M}_{\text {cov }}$ ), a bivariate mixed model $\left(\mathrm{BMM}_{\ominus}\right)$, and a recursive mixed model including $\mathrm{pH}$ as a cross-classified effect in the in the model of fertility ( RMM $\left._{\text {cross }}\right)$.

\section{Effect of AI dose concentration and physiological status of the female on fertility}

For simplicity, only results from model $\mathrm{UMM}_{\text {cov }}$ are presented (the other models give similar results).

The amount of sperm per dose had and important effect on Fert. The EMPD of differences in Fert\% between AI at 40 or $10 \times 10^{6}$ of spermatozoa /mL was 10.0 (HPD $95 \%: 11.8,8.0$ ). It is known that increasing concentration can compensate for some seminal deficiencies associated with low fertility (Saacke et al., 2000, Farrell et al., 1993; Alvariño et al., 1996; Viudes-deCastro and Vicente, 1997).

Lactation had a negative effect on Fert. The EMPD of differences in Fert \% between lactating and not lactating females was $-5.2 \mathrm{HPD}_{95 \%}=[-8.1,-2.5]$. This result agrees with previous estimates obtained after natural mating in the same line (Piles et al., 2005) and in another breed, where receptive and lactating females had a lower kindling rate than the ones not in 
lactation (Brun et al., 2002). Lactation produces a decrease in female receptivity, ovulation rate and ovulation frequency, and also increases the number of embryo deaths and post implantation mortality (Théau-Clément and Roustan, 1992; Fortun and Bolet, 1995). Although in this work ovulation was hormonally induced, some negative effects of lactation on female fertility had not been totally suppressed.

\section{Conclusions}

There is a quasi linear negative effect of $\mathrm{pH}$ of semen on fertility in rabbits. This effect could be equally estimated using either recursive or classical multivariate models. Both types of models predicted fertility data reasonably well. No differences in the prediction of the EBV for male fertility were encountered between models showing a good concordance when the animals were ranked by their EBV and in their average EBV of the top $10 \%$ best animals. Thus, from the point of view of selection, irrespective of the model of choice, small changes would be encountered in the animal's evaluation for male fertility. The fact that models were almost equivalent despite differing in complexity could be due to the small recursiveness effect of $\mathrm{pH}$ on Fert and the low precision obtained for the parameter estimates.

The $\mathrm{pH}$ of semen could be used to select qualitatively better ejaculates in order to increase fertility. However, despite the moderate value of heritability obtained for this trait, it does not seem to be advisable to use the semen $\mathrm{pH}$ as selection criterion to improve male fertility by indirect selection since the genetic correlation between the two traits might not be high enough.

\section{Literature cited}

Alvariño, J. M. R. 2000. Reproductive performance of male rabbits. Proc. 7th World Rabbit Congr., Valencia, Spain. A:13-35.

Alvariño, J. M. R., F. J. López, J. A. Del Arco, R. Bueno, and R. Torres. 1996. Effects of semen concentration on rabbit artificial insemination with fresh or 24 hours stored semen. Proc. 6th World Rabbit Congr., Toulouse, France 2:33-35.

Amann, R. P., and R. H. Hammerstedt. 2002. Detection of differences in fertility. J. Androl. 23: 317-325.

Bencheikh, N. 1995. The effect of frequency of ejaculation on semen characteristics and sperm output in the rabbit. Ann. Zootech. 44:263-279.

Brun, J.M., A. Sanchez, R. Duzert, G. Saleil, and M. Theau-Clément. 2009. Paramètres génétiques des caractéristiques de la semence de lapin. 13 èmes Journ. Rech. Cunicole, Le Mans, France. 11:17-18.

Brun, J. M., M. Theau-Clement, and G. Bolet. 2002. The relationship between rabbit semen characteristics and reproductive performance after artificial insemination. Anim. Reprod. Sci. 70:139-149. 
Coffey, D. S. 1988. Androgen action and the sex accessory tissues. In: Physiology of reproduction, knobil, E., Neill, J. D. (Eds.), Raven Press, New York, pp. 1081-119.

de los Campos, G., D. Gianola, P. Boettcher, and P. Moroni. 2006. A structural equation model for describing relationships between somatic cell score and milk yield in dairy goats. J. Anim Sci. 84:2934-2941.

Estany, J., M. Baselga, A. Blasco, and J. Camacho. 1989. Mixed model methodology for the estimation of genetic response to selection in litter size of rabbits. Livest. Prod. Sci. 21:67-75.

Falconer, D. S. 1965. The inheritance of liability to certain diseases, estimated from the incidence among relatives. Ann. Hum. Genet. 29: 51-76.

Farrell, B. P., R. H. Foote, M. E. Simkin, E. D. Clegg, and R. J. Wall. 1993. Relationship of semen quality, number of sperm inseminated, and fertility in rabbits. J. Androl. 14:464-471.

Fortun, F., and G. Bolet. 1995. Les effets de la lactation sur les performances de reproduction chez le lapine. INRA Prod. Anim. 8:49-56.

Foulley, J. L., D. Gianola, and R. Thompson. 1983. Prediction of genetic merit from data on binary and quantitative variates with an application to calving difficulty, birth weight and pelvic opening. Genet. Sel. Evol. 15(3):401-424.

Garcia-Tomás, M., J. Sanchez, O. Rafel, J. Ramon, and M. Piles. 2006a. Variability, repeatability and phenotypic relationships of several characteristics of production and semen quality in rabbit. Anim. Reprod. Sci. 93:88-100.

Garcia-Tomás, M., J. Sanchez, O. Rafel, J. Ramon, and M. Plies. 2006b. Heterosis, direct and maternal genetic effects on semen quality traits of rabbits. Livestock Science 100: 111-120.

Geweke, J. 1992. Evaluating the accuracy of sampling-based approaches to the calculation of posterior moments. Oxford University Press, 1992.

Geyer, C. J. 1992. Practical Markov Chain Monte Carlo. Stat. Sci. 7:473-511.

Gianola, D., and D. Sorensen. 2004. Quantitative genetic models for describing simultaneous and recursive relationships between phenotypes. Genetics 167:1407-1424.

Gianola, D., and R. L. Fernando. 1986. Bayesian methods in animal breeding theory. J. Anim Sci. 63: $217-244$

Gómez, E.A., O. Rafel, J. Ramon. 2002. The Caldes strain (Spain). Options Méditerranéennes. Série B, Études et Recherches 38:193-198.

Gómez, E. A., O. Rafel, J. Ramon, and M. Baselga. 1996. A genetic study of a line selected on litter size at weaning. Proc. 6th World Rabbit Congr., Toulouse, France 2:289-292.

Hulet, C. V., and S. K. Ercanbrack. 1962. A fertility index for rams. J. Anim Sci. 21:489-493.

Lavara, R., E. Moce, F. Lavara, M. P. V. de Castro, and J. S. Vicente. 2005. Do parameters of seminal quality correlate with the results of on-farm inseminations in rabbits? Theriogenology. 64:1130-1141.

Legarra, A., L. Varona, and E. López de Maturana. 2008. TM Threshold Model. http://snp.toulouse.inra.fr/ alegarra/manualtm.pdf Accessed Oct 31, 2008.

López de Maturana, E., A. Legarra, L. Varona, and E. Ugarte. 2007. Analysis of fertility and dystocia in holsteins using recursive models to handle censored and categorical data. J. Dairy Sci. 90:2012-2024.

López de Maturana, E., X.-L. Wu, D. Gianola, K. A. Weigel, and G. J. M. Rosa. 2009. Exploring biological relationships between calving traits in primiparous cattle with a bayesian recursive model. Genetics 181: 277-287. 
López de Maturana, E., G. de los Campos, X-L.Wu, D. Gianola , K. Weigel, and G.J.M. Rosa. 2010. Modeling relationships between calving traits: a comparison between standard and recursive mixed models. Genet. Sel. Evol. 42:1. doi:10.1186/1297-9686-42-1.

More O'Ferrall, G. J., and T. N. Meacham. 1968. Relationship between pH, other semen traits and fertility in rabbits. VIe Cong. Intern. Reprod. Anim. Insem. Artif. Paris 2:1279-1281.

Piles, M., O. Rafel, J. Ramon, and L. Varona. 2005. Genetic parameters of fertility in two lines of rabbits with different reproductive potential. J. Anim. Sci. 83:340-343.

Raftery, A. E., and S. Lewis. 1992. How many iterations in the Gibbs Sampler? Bayesian Statistics 4. Oxford Univ. Press, NY.

Saacke, R. G., J. C. Dalton, S. Nadir, R. L. Nebel, and J. H. Bame. 2000. Relationship of seminal traits and insemination time to fertilization rate and embryo quality. Anim. Reprod. Sci. 60:663-677.

Sorensen, D., and D. Gianola. 2002. Likelihood, bayesian, and MCMC methods in quantitative genetics. Springer Science + Business Media, LLC, 233 Spring Street, NY.

Sorensen, D. A., S. Andersen, D. Gianola, and I. Korsgaard. 1995. Bayesian-Inference in Threshold Models using Gibbs Sampling. Genet. Sel. Evol. 27:229-249.

Théau-Clément, M., and A. Roustan. 1992. A study on relationships between receptivity and lactation in the doe and their influence on reproductive performances. J. Appl. Res. 15:412421.

Tusell, L., M. García-Tomás, M. Baselga, R. Rekaya, O. Rafel, J. Ramon, M. López-Bejar, and M. Piles. 2010. Genotype x AI conditions interaction for male effect on fertility and prolificacy. J. Anim. Sci. 88: 3475-3485.

Tusell, L., O. Rafel, J. Ramon, and M. Piles. 2009. Genetic analysis of fertility and average daily gain in rabbit EAAP- 60th Annual Meeting of the European Federation of Animal Science EAAP, 2009, Barcelona, Spain. 15: 172-172.

Varona, L., D. Sorensen, and R. Thompson. 2007. Analysis of litter size and average litter weight in pigs using a recursive model. Genetics 177:1791-1799.

Viudes-de-Castro, M. P., and J. S. Vicente. 1997. Effect of sperm count on the fertility and prolificity rates of meat rabbits. Anim. Reprod. Sci. 46:313-319.

Wright, S. 1934. An analysis of variability in number of digits in an inbred strain of guinea pigs. Genetics 19:0506-0536.

Wu, X.-L., B. Heringstad, and D. Gianola. 2008. Exploration of lagged relationships between mastitis and milk yield in dairy cows using a bayesian structural equation gaussian-threshold model. Gen. Sel. Evol. 40:333-357 


\section{Chapter three. Product versus}

\section{additive model for studying artificial insemination results in several livestock species: Rabbits}

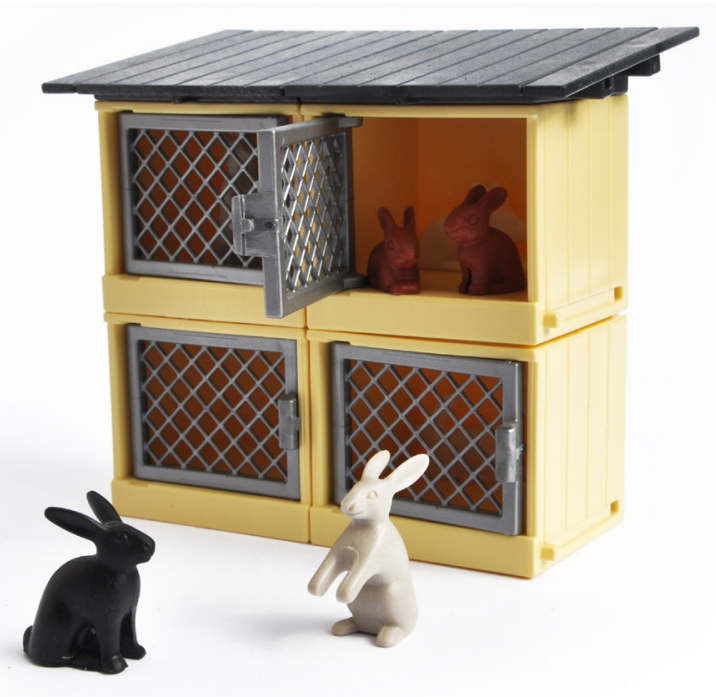

In this chapter rabbit male and female contributions to fertility were analysed under two different approches: the additive and the product threshold model. Rabbit results and discussion presented in this chapter are included in a study published in J. Anim. Sci. 2011. 89:321-328 in which two other species were also analysed. Refer to the APPENDIX of this thesis for further details of the whole study. 


\section{Abstract}

The additive and the product threshold models for the analysis of success or failure to AI were compared in terms of their predictive ability. These models have different assumptions. In the additive threshold model, the observed phenotype is linked to a liability which is the sum of all genetic and environmental factors affecting male and female fertility. However, the product threshold model considers that the conditional probability of AI success is the product of the probability of success of 2 binary unobserved phenotypes: the male and female fertilities. The 2 corresponding liabilities are the sum of genetic and environmental factors specific to the considered mate-sex and also those common to both sexes.

A total of 6,543 records corresponding to the output of $\mathrm{AI}$ in a paternal line of rabbits were used for the analysis. AI were performed with fresh semen diluted 1:4 in a commercial extender. No evaluation of seminal characteristics was performed. Success or failure of AI was obtained from the diagnosis of pregnancy made by palpation $14 \mathrm{~d}$ after AI, and confirmed with the information on the day of parturition. The observed probability of AI success was $72 \%$.

The ability to predict fertility data of the product model was similar to the additive model (percentage of wrong prediction $=27$ in the additive model; 28 in the product model in rabbits). Correlations between predicted breeding values obtained in the two models were very high ( 0.93 and 0.96 for male and female EBV, respectively). The product model can determine which sex is responsible for an AI failure. The female was the responsible in $54 \%$ of the cases and the male in $39 \%$ of them.

Key words: additive model, fertility, predictive ability, product model. 


\section{Introduction}

The outcome of $\mathrm{AI}$ is affected by factors related to the male, the female, or factors common to both sexes. The outcome of AI may be registered as a binary code indicating pregnancy or nonpregnancy. The most common approach in animal genetic models for such a binary trait is the additive threshold model, which proposes a underlying variable resulting from the addition of environmental and genetic effects from the 2 individuals involved in the mating (Varona and Noguera, 2001; Piles et al., 2005). However, some authors have pointed out that the combination of those sources of variation may not be purely additive (Speirs et al., 1983). Recently, David et al. (2009) proposed a product threshold model assuming that conception in a given mating is the product of the outcome of each mating member. Hence, the conditional probability of AI success is the product of the probabilities of the success of 2 unobserved binary phenotypes (one is the male fertility; the other is the female fertility). This assumption has several advantages over that assumed in the additive model. First, it describes in a better manner the biological mechanism of the mating. Second, it provides distinct estimates of environmental effects affecting each of the 2 unobserved phenotypes, and as a result allows more information to be extracted from the data. David et al. (2009) showed the feasibility of this model in a genetic context using simulated data. However, the product threshold model has not been applied to real data yet. The purpose of this study was to compare the performance, in terms of predictive ability, of the product and additive threshold models for studying AI result in rabbits.

\section{Materials and methods}

\section{Materials}

Data came from a population of a sire line selected for growth rate (Caldes line: Gomez et al., 2002). Data collected from June 2003 to November 2008 were used in this study. For the preparation of AI doses, ejaculates containing urine and calcium carbonate deposits were discarded, and gel plugs were removed. No evaluation of seminal characteristics was performed. Ejaculates were diluted 1:4 (vol/vol) immediately after collection to obtain the AI doses. Female estrus and ovulation were induced by hormonal treatment. Artificial insemination doses of $0.5 \mathrm{~mL}$ were applied within $1 \mathrm{~h}$ after preparation on females from the same sire line, also reared in the nucleus of selection. Success or failure of AI was obtained from the diagnosis of pregnancy made by palpation $14 \mathrm{~d}$ after AI. Information on the day of parturition helped to confirm the previous diagnosis of palpation. A total of 6,543 AI records were used for the analysis. The observed probability of AI success was $72 \%$. Basic summary statistics of the AI data are presented in Table 3.1. The pedigree included 3,302 individuals. 
Table 3.1. Description of fertility data

\begin{tabular}{lc}
\hline Item & \\
\hline Number of females & 2,601 \\
Number of males & 300 \\
Number of AI records & 6,543 \\
Number of animals in the pedigree & 3,302 \\
Mean [P25,P75] ${ }^{1}$ number of & 21.8 \\
observations per male & {$[9,30]$} \\
Mean [P25,P75] ${ }^{1}$ number of & 2.5 \\
observations per female & {$[1,3]$} \\
Mean [P25,P75] ${ }^{1}$ number of different & 19 \\
inseminated females per male & {$[9,26]$} \\
Mean [P25,P75] ${ }^{1}$ number of different & 2.2 \\
males per female & {$[1,3]$} \\
Mean [P25,P75] ${ }^{1}$ probability of AI & 0.70 \\
success per male & {$[0.60,0.83]$} \\
Mean [P25,P75] ${ }^{1}$ probability of AI & 0.69 \\
success per female & {$[0.50,1.00]$} \\
Observed probability of AI success & 0.72 \\
Values presented as mean [P25, P75]. P25, P75: 25th and 75th percentile
\end{tabular}

\section{Methods}

Additive and product threshold models suppose different assumptions. In the additive threshold model, the observed phenotype is linked (probit link function) to a liability which is the sum of all genetic and environmental factors affecting male and female fertility. Thus, under the additive model the conditional probability of success given the genetic and environmental factors can be expressed as:

$$
\operatorname{Pr}(y=1 \mid \theta)=\Phi\left(X_{f} \beta_{f}+X_{c} \beta_{c}+Z_{f} u_{f}+Z_{m} \boldsymbol{u}_{m}+W_{m} p_{m}+W_{f} p_{f}+M_{n} \boldsymbol{m}_{n}\right)
$$

where $\boldsymbol{y}$ is the vector of the binary results of inseminations; $\operatorname{Pr}(\boldsymbol{y}=1 \mid \boldsymbol{\theta})$ is the conditional (given the genetic and environmental factors variables $\boldsymbol{\theta}$ ) probability of AI success. The $\Phi($. is the standard cumulative distribution function of the normal distribution. Term $\boldsymbol{\beta}_{\boldsymbol{f}}$ is the vector of systematic effects related to the female including the physiological status of the female (3 levels: nulliparous does, multiparous does in lactation, and multiparous does not in lactation). Term $\beta_{c}$ is the vector of systematic effects common to both sexes which included the day of AI (22 levels, approximately 3 mo intervals). Although it could be included in the model, no systematic effect specifically related to the male was considered in this study. The $u_{f}$ and $u_{m}$ are the vectors of female and male fertility additive genetic effects, respectively. The $\boldsymbol{p}_{\boldsymbol{m}}$ and $\boldsymbol{p}_{\boldsymbol{f}}$ correspond to the vectors of male and female random permanent environmental effects; and $\boldsymbol{m}_{\boldsymbol{n}}$ is the vector of permanent environmental effects resulting from the combination between the male and the day on which AI was eprformed. $\boldsymbol{X}_{f}, \boldsymbol{X}_{m}, \boldsymbol{X}_{c}, \boldsymbol{Z}_{f}, \boldsymbol{Z}_{m}, \boldsymbol{W}_{f}, \boldsymbol{W}_{m}$ and $\boldsymbol{M}_{\boldsymbol{m}}$ are the corresponding known incidence matrices. 
On the other hand, the product threshold model considers that the conditional probability of AI success is the product of the probability of success of 2 binary unobserved phenotypes: the male and female fertilities (David et al., 2009). The 2 corresponding liabilities are the sum of genetic and environmental factors specific to the considered mate-sex and also those common to both sexes:

$$
\begin{aligned}
& \operatorname{Pr}(\boldsymbol{y}=1 \mid \boldsymbol{\theta})=\Phi\left(\boldsymbol{X}_{f} \boldsymbol{\beta}_{f}+\boldsymbol{X}_{c} \boldsymbol{\beta}_{c}+\boldsymbol{Z}_{f} \boldsymbol{u}_{f}+\boldsymbol{W}_{f} \boldsymbol{p}_{f}\right) \\
& \times \Phi\left(\boldsymbol{X}_{c} \boldsymbol{\beta}_{c}+\boldsymbol{Z}_{\boldsymbol{m}} \boldsymbol{u}_{\boldsymbol{m}}+\boldsymbol{W}_{\boldsymbol{m}} \boldsymbol{p}_{\boldsymbol{m}}+\boldsymbol{M}_{\boldsymbol{n}} \boldsymbol{m}_{\boldsymbol{n}}\right)
\end{aligned}
$$

In both models, all random effects were assumed to be distributed following centered normal distributions with (co)variance matrices equal to $\left[\begin{array}{cc}\sigma_{u_{m}}^{2} & \sigma_{u_{f} u_{m}} \\ \sigma_{u_{f} u_{m}} & \sigma_{u_{f}}^{2}\end{array}\right] \otimes \mathbf{A}$ for the correlated genetic effects and $\boldsymbol{I}_{q} \sigma_{q}^{2}$ for the other random effects $\left(q=p_{f}, p_{m}, m_{n}\right)$, being $\mathbf{A}$ the known relationship matrix and $\otimes$ represents the Kronecker product, $I_{q}$ is an identity matrix of appropriate dimension, and $\sigma_{q}^{2}$ is the corresponding variance for the effect $q$. Nongenetic random effects were assumed to be independent to each other and to genetic effects.

Heritabilities on the observed scale were computed following the transformation proposed by Dempster and Lerner (1950):

In the additive threshold model, $h_{\text {female_fertility }}^{2}=\frac{\sigma_{u_{f}}^{2}}{\sigma_{T}^{2}} \times z^{2} /\left(P_{o b s} \times\left(1-P_{o b s}\right)\right)$ and $h_{\text {male_fertility }}^{2}=\frac{\sigma_{u_{m}}^{2}}{\sigma_{T}^{2}} \times z^{2} /\left(P_{o b s} \times\left(1-P_{o b s}\right)\right)$, for the female and male fertility, respectively, where $P_{o b s}$ is the observed probability of AI success. The total variance $\sigma_{T}^{2}$ was calculated as $\sigma_{T}^{2}=\sigma_{u_{f}}^{2}+\sigma_{u_{m}}^{2}+\sigma_{p_{f}}^{2}+\sigma_{p_{m}}^{2}+\sigma_{m_{n}}^{2}+\sigma_{e}^{2}$, term $z$ is the ordinate of a standard normal distribution function corresponding to a threshold equal to $\Phi^{-1}\left(P_{o b s}\right)$ and $\sigma_{e}^{2}$ is the residual variance of the liability fixed to 1 .

For the product threshold model,

$$
h_{\text {female_fertility }}^{2}=\frac{\sigma_{u_{f}}^{2}}{\sigma_{T_{1}}^{2}} \times z_{f}^{2} /\left(P_{o b s} \times\left(1-P_{o b s}\right)\right) \text { and }
$$


$h_{\text {male_fertility }}^{2}=\frac{\sigma_{u_{m}}^{2}}{\sigma_{T_{2}}^{2}} \times z_{m}^{2} /\left(P_{o b s} \times\left(1-P_{o b s}\right)\right)$, for female and male fertility, respectively. Where $\sigma_{T_{1}}^{2}=\sigma_{u_{f}}^{2}+\sigma_{p_{f}}^{2}+\sigma_{e_{f}}^{2}$ and $\sigma_{T_{2}}^{2}=\sigma_{u_{m}}^{2}+\sigma_{p_{m}}^{2}+\sigma_{m_{n}}^{2}+\sigma_{e_{m}}^{2}$. The $z_{f}$ and $z_{m}$ are the ordinates of a standard normal distribution functions corresponding to thresholds equal to $\Phi^{-1}\left(P_{f}\right)$ and $\Phi^{-1}\left(P_{m}\right) . P_{f}, P_{m}$ are the probabilities of success for the unobserved phenotypes of female and male fertility, respectively, and $\sigma_{e_{f}}^{2}$ and $\sigma_{e_{m}}^{2}$ are the residual variances of the male and female liabilities fixed to 1 , respectively.

\section{Implementation}

Data set was analyzed using the additive and product threshold model. The same random, systematic, and genetic effects were included in both models. Under the product model, effects were considered as specific to the male, to the female, or common to both sexes. In a first step, additive and product threshold models were compared based on their ability of predicting new records as follows: 75\% of records were used to estimate parameters, and the new records were predicted in the remaining $25 \%$. Five replicates of this design were randomly sampled. Different statistics were computed to evaluate the predictive ability of the 2 models using the same record sets: a) the percentage of wrong prediction; b) the mean square error of prediction (MSEP) defined as $M S E P=\frac{1}{n} \sum_{i}^{n}\left(y_{i}-\hat{P}\left(y_{i}=1\right)\right)^{2}$, where $y_{i}$ and $\hat{P}\left(y_{i}=1\right)$ correspond to the observed AI outcome and predicted probability of success, respectively, and $n$ is the number of data in a testing subset; c) the sensitivity of the prediction defined as the probability to predict a success given that the observation is a success; d) the specificity or the probability to predict a failure given that the observation is a failure; e) the negative predictive value defined as the probability to observe a failure given that the prediction is a failure; and f) the positive predictive value or the probability to observe a success given that the prediction is a success. In a second step, the estimated parameters obtained with the 2 models on the whole data set were compared. The Pearson correlation between predicted breeding values and the percentage of animals in common in the top and bottom $10 \%$ animals were used to evaluate the differences in results between the 2 models.

Estimates were obtained using a Bayesian approach via Gibbs sampling. The core of the program is the TM (threshold model) software developed by Legarra et al. (2008). Flat priors were used for systematic effects and variance components, and starting values were randomly 
sampled. The Gibbs sampler analysis was implemented using one single chain consisting of 500,000 iterations. After discarding the first 50,000 iterations, samples of the parameters of interest were saved every 100 iterations. Inferences on the marginal posterior distributions were directly performed from the retained samples. Posterior means were used as parameter estimates.

\section{Results}

Table 3.2 shows the predictive ability estimates for each model obtained for each criterion used. The MSEP estimates were similar between the product and additive model. The percentages of wrong prediction for both models were in agreement. The negative and positive predictive values are quite similar between models, whereas the product model tended to be more sensitive and less specific than the additive one.

Table 3.2. Predictive ability of the product and additive threshold models

\begin{tabular}{lcc}
\hline Item & $\begin{array}{c}\text { Product } \\
\text { model }\end{array}$ & $\begin{array}{c}\text { Additive } \\
\text { model }\end{array}$ \\
\hline$\%$ of wrong prediction & 28 & 27 \\
MSEP $^{1}$ & 0.16 & 0.15 \\
Sensitivity & 0.99 & 0.98 \\
Specificity & 0.06 & 0.10 \\
Negative predictive & 0.66 & 0.66 \\
value & & \\
Positive predictive & 0.72 & 0.73 \\
value & & \\
TMSEP = mean square error of prediction & &
\end{tabular}

Results obtained for the whole data sets (Table 3.3) showed that the probability of success estimates for the unobserved phenotypes obtained from the product model were similar for both sexes: the probability of success of male and female fertility was 0.87 and 0.83 , respectively.

The estimated heritabilities on the observed scale were low for male and female contributions to fertility in both models but greater for the product than for the additive model. The posterior means of the genetic correlation $\left(\mathbf{r}_{\mathrm{g}}\right)$ between male and female fertilities were estimated with reduced credibility irrespectively of the models. The probability of a positive value of the $r_{g}$ was 0.67 and 0.78 in the product and in the additive threshold model, respectively. The correlations between EBV for all animals in the pedigree as well as for animals with records obtained with the additive or product threshold models were very large (all of them higher than 92\%). Accordingly with the EBV correlations, the percentage of animals in common in the $10 \%$ best/worst animals was large $(\geq 0.73)$. 
Table 3.3. Posterior means and highest posterior density interval at $95 \%$ (in brackets) of the probability of success for the unobserved phenotypes, genetic and environmental variances, heritabilities, and correlation between breeding values obtained with the product and additive threshold model

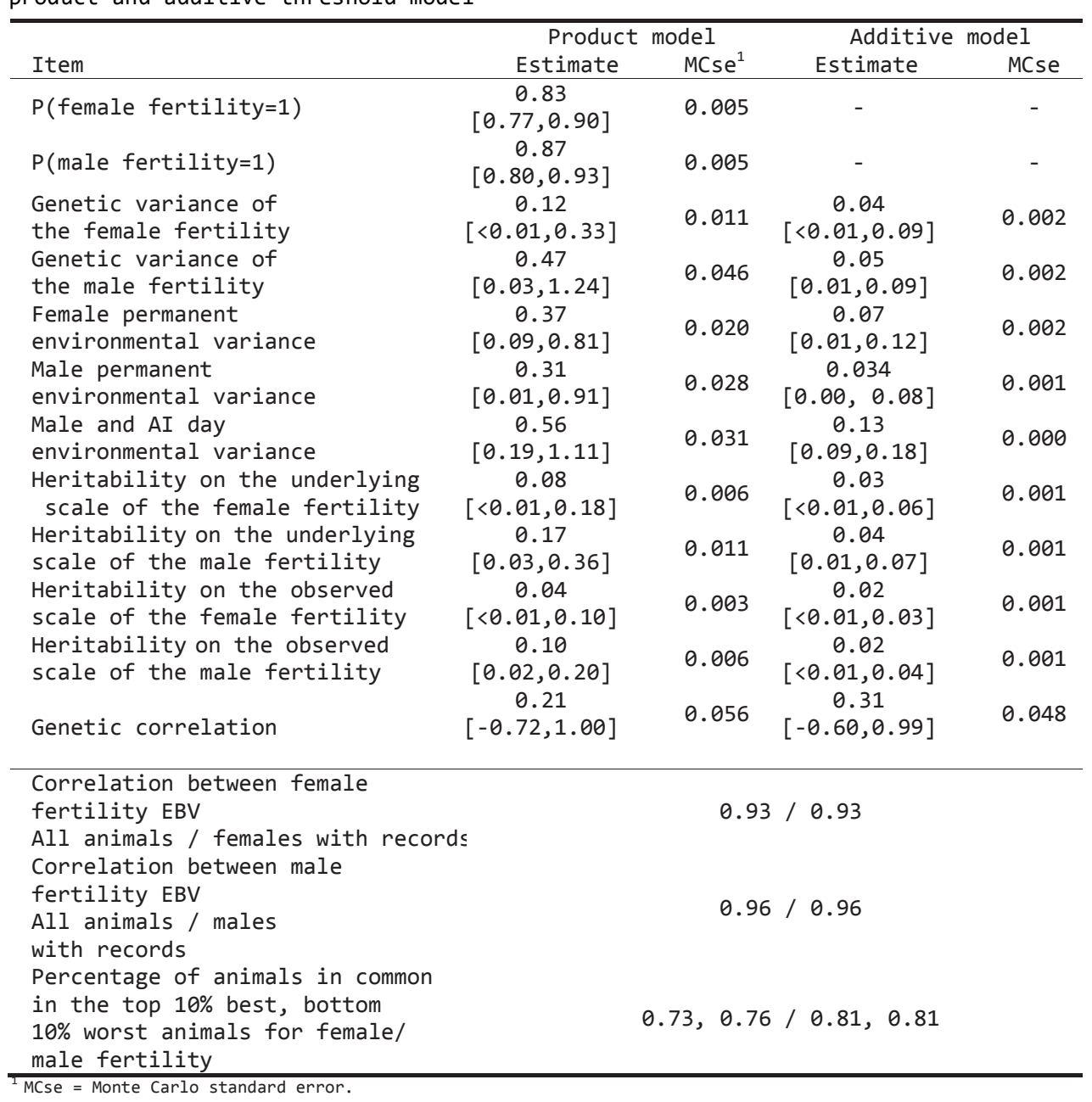

\section{Discussion}

The observed probabilities of AI success are in accordance with previous studies in rabbits (El Gaafary and Marai, 1994). Under the product model, environmental factors can be distinctly attached to male, female, or to both, which cannot be done under an additive model. This choice is straightforward for some effects (e.g., physiological status of the female) but not for all (e.g., AI day). The relevance of alternative effects acting on male or female fertility can be explored by classical model comparison techniques. We explored for a subset of data the selection of effects in the product threshold model. We first estimated parameters in a saturated model including all factors for male and female fertility. We removed step-by-step factors for which all highest posterior density intervals at 95\% (HPD ${ }_{95 \%}$ ) included 0 . The final model obtained is consistent in the face of the factors included in both sides, illustrating the ability of the product model to correctly assign a factor as acting on male or female fertility, or both (results not shown). 
The sampling method that we used to evaluate the predictive ability of the 2 models does not correspond to a standard 5 -fold cross-validation (Shao, 1993). In this paper, random sampling was repeated 5 times, making sure that all random and systematic effect levels (except female permanent effect) in the testing sample were estimated previously in the training sample. This sampling method was used to avoid unexpected consequences of missing estimation for the additive or product models. Nonetheless, a 5-fold cross-validation was performed with the data and provided results very close to those presented in this study (results not shown). The similar results obtained for MSEP and percentage of wrong prediction show that product and additive threshold models have the same predictive ability. Nonetheless, as reported in previous studies for comparison with other models (Vazquez et al., 2009a,b), predictive ability of the models is different depending on the observed result. Therefore, differences in predictive ability between the models could appear if dataset of other characteristics is used. The product model was more sensitive and less specific than the additive one. Therefore, the product model had a better ability to predict a success and a worse ability to predict a failure than the additive model.

Although correlations between EBV obtained in the two models were very high, animals will not be identically selected with the 2 models. These results suggest that either the additive or the product model may provide inaccurate predictions for male fertility. As true breeding values are unknown, further studies are necessary to determine what model is more accurate in predicting male fertility. An experimental selection with the 2 models, could be a way to give an answer to this question.

Heritabilities estimated with the additive threshold model were small for male and female contributions to fertility, but in accordance with the ones obtained in a study in the same line after natural mating (Piles et al., 2005). Heritabilities obtained with the product model cannot be related to the accuracy of the estimation or the genetic progress in the same manner as in the additive model. Therefore, estimation of heritabilities obtained with the 2 models cannot be properly compared, even if they are expressed in the observed scale. Further investigations are needed to give a practical interpretation of the heritability in the product threshold model. Under the additive threshold model one studied the liability to conception (observable phenotype) and heritability referred to the genetic variation contributed by male or female to liability to conception. Under the product threshold model one studied the liability to being a fertile male (non-observable male phenotype) and the liability to being a fertile female (nonobservable female phenotype), and the estimated heritabilities referred to genetic contribution to those two liabilities by male and female.

Conversely to the heritabilities, the genetic correlation between male and female fertilities can be compared across models. The $\mathrm{HPD}_{95 \%}$ for the 2 estimates were very large and the 
probability of a positive value were not very high, but the posterior mean was similar in magnitude. This result was in accordance with the genetic correlation between male and female contributions to fertility obtained after natural mating in the same paternal line of rabbits $\left(0.73, \mathrm{HPD}_{95 \%}=-0.36,0.99\right.$; Piles et al., 2005). Estimated probabilities of success for the unobserved phenotypes indicated that an AI failure was specifically due to female fertility problems for $54 \%$ of the cases and was specifically due to male fertility problems for $39 \%$ of the cases. Therefore, it seems that the product model reports that an AI failure is mainly due to impairment in female. It is difficult to compare these results with those reported previously in the literature. Actually, the only species where origin of infertility is well documented is humans after natural mating (Forti and Krausz, 1998). Forti and Krausz (1998) reported that in $35 \%$ of cases, infertility is mainly due to a female factor, in $30 \%$ to a male factor, in $20 \%$ to abnormalities detected in both partners, and in $15 \%$ of cases no diagnosis can be made after a complete investigation. In our study, there was almost no ejaculate selection upon its seminal characteristics (except urine or calcium deposits), and there was no standardization of the AI dose concentration. This process may induce a decrease in the potential sperm fertility and explain the relative importance of the male in the AI failure. For female fertility, ovulation is induced after insemination in rabbits; therefore, the probability that the oocyte is released at the optimum time in the female reproductive tract is very large, which might explain the high percentage of female fertility success observed (0.83).

We think that the product model is, at present, an interesting model to test for studying AI results, or other traits with the same kind of associated binary unobserved phenotypes, in an experimental context.

The objective of this study was to evaluate the performance of the product threshold model for the modeling of the outcome of AI. We have shown that its predictive ability is similar to the additive model. The product model has the advantage of extracting more information from the data than the additive threshold model. It is possible to evaluate which sex is responsible for an AI failure, and this would help to improve fertility. However, product model suffers from some drawbacks. Interpretation of genetic parameters estimates is not straightforward and it is necessary to work on the estimation of the genetic progress in this model. At present, estimations are obtained using a Bayesian approach and the computing time could be very long if data set used is very large.

\section{Literature cited}

Briois, M., and Y. Guerin. 1995. Essais de diminution du nombre de spermatozoides par dose conduits au centre d'insemination artificielle ovine de la confederation de roquefort. Pages 421-424 in Proc. 2nd Renc. Rech. Rumin., Paris, France. Institute de l'Elevage-INRA, Paris, France. 
David, I., L. Bodin, D. Gianola, A. Legarra, E. Manfredi, and C. Robert-Granie. 2009. Product versus additive threshold models for analysis of reproduction outcomes in animal genetics. J. Anim. Sci. 87:2510-2518.

David, I., L. Bodin, G. Lagriffoul, C. Leymarie, E. Manfredi, and C. Robert-Granie. 2007. Genetic analysis of male and female fertility after AI in sheep: Comparison of single trait and joint models. J. Dairy Sci. 90:3917-3923.

David, I., C. Robert-Granie, E. Manfredi, G. Lagriffoul, and L. Bodin. 2008. Environmental and genetic variation factors of artificial insemination success in French dairy sheep. Animal 2:979-986.

Dempster, E. R., and I. M. Lerner. 1950. Heritability of threshold characters. Genetics 35:212236.

Donovan, A., J. P. Hanrahan, E. Kummen, P. Duffy, and M. P. Boland. 2004. Fertility in the ewe following cervical insemination with fresh or frozen-thawed semen at a natural or synchronised oestrus. Anim. Reprod. Sci. 84:359-368.

El Gaafary, M. N., and I. F. M. Marai. 1994. Artificial insemination in rabbits. Pages 95-110 in Proc. 1st Int. Conf. on Rabbit Prod. in Hot Climates, Cairo, Egypt. CIHEAM, Paris, France.

Fernandez-Abella, D., M. O. Preve, and N. Villegas. 2003. Insemination time and dilution rate of cooled and chilled ram semen affects fertility. Theriogenology 60:21-26.

Foote, R. H. 2003. Fertility estimation: A review of past experience and future prospects. Anim. Reprod. Sci. 75:119-139.

Forti, G., and C. Krausz. 1998. Clinical review 100: Evaluation and treatment of the infertile couple. J. Clin. Endocrinol. Metab. 83:4177-4188.

Gomez, E. A., O. Rafel, and J. Ramon. 2002. The Caldes strain. Rabbit genetic resources in Mediterranean countries. Options mediterraneennes, serie B: Etudes et recherches 189-198.

Gonzalez-Recio, 0., and R. Alenda. 2005. Genetic parameters for female fertility traits and a fertility index in Spanish dairy cattle. J. Dairy Sci. 88:3282-3289.

Legarra, A., L. Varona, and E. Lopez de Maturana. 2008. TM Threshold Model. Accessed Oct. 31, 2008. http://snp.toulouse. inra.fr/ alegarra/manualtm.pdf.

Lucy, M. C. 2001. Reproductive loss in high-producing dairy cattle: Where will it end? J. Dairy Sci. 84:1277-1293.

Moreno, C., D. Sorensen, L. A. Garcia-Cortes, L. Varona, and J. Altarriba. 1997. On biased inferences about variance components in the binary threshold model. Gen. Sel. Evol. 29:145160.

Piles, M., O. Rafel, J. Ramon, and L. Varona. 2005. Genetic parameters of fertility in two lines of rabbits with different reproductive potential. J. Anim. Sci. 83:340-343.

Shao, J. 1993. Linear model selection by cross-validation. J. Am. Stat. Assoc. 88:486-494.

Speirs, A. L., A. Lopata, M. J. Grnow, G. N. Kellow, and W. I. H. Johnston. 1983. Analysis of the benefits and risks of multiple embryo transfer. Fertil. Steril. 39:468-471.

Varona, L., and J. L. Noguera. 2001. Variance components of fertility in Spanish Landrace pigs. Livest. Prod. Sci. 67:217-221.

Vazquez, A. I., D. Gianola, D. Bates, K. A. Weigel, and B. Heringstad. 2009a. Assessment of Poisson, logit, and linear models for genetic analysis of clinical mastitis in Norwegian Red cows. J. Dairy Sci. 92:739-748.

Vazquez, A. I., K. A. Weigel, D. Gianola, D. M. Bates, M. A. Perez- Cabal, G. J. M. Rosa, and Y. M. Chang. 2009b. Poisson versus threshold models for genetic analysis of clinical mastitis in US Holsteins. J. Dairy Sci. 92:5239-5247 


\section{Chapter four. Interaction of}

\section{genotype $\times$ artificial insemination conditions for male effect on fertility and prolificacy}

L. Tusell, M. García-Tomás, M. Baselga, R. Rekaya, O. Rafel, J. Ramon, M. López-Bejar

and M. Piles

J. Anim. Sci. 2010. 88:3475-3485

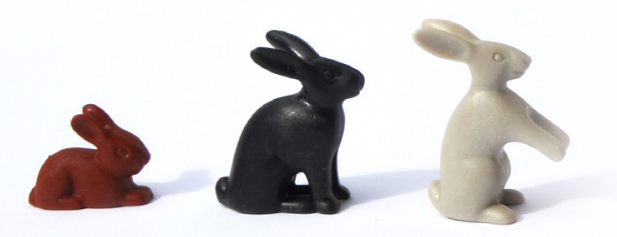

This research was supported by the Instituto Nacional de Investigacion y Tecnologia Agraria y Alimentaria (INIA, Madrid, Spain) project RTA2005-00088-CO2. Part of the research was carried out during a visit by the first author to the Animal and Dairy Science Department, University of Georgia, Athens. Llibertat Tusell Palomero received a fellowship from the INIA. The authors thank Anna Perez, Carme Requena and Oscar Perucho (Unitat de Cunicultura, IRTA, Caldes de Montbui, Barcelona, Spain), and Daniel and Sinela Mozer Schonborn (Montmajor, Barcelona, Spain) for their valuable cooperation during the experimental phase of this study and Andres Legarra (INRA UR 631 Station d'Amelioration Genetique des Animaux, Castanet-Tolosan, France) and Ignacio Aguilar (University of Georgia, Athens) for their comments and suggestions. 


\section{Abstract}

Failures in fertilization or embryogenesis have been shown to be partly the result of poor semen quality. When AI is practiced, fertilization rate depends on the number and quality of spermatozoa in the insemination dose around the time of application. Individual variation in the male effect on fertility (success or failure to conceive; Fert) and prolificacy (total number of kits born per litter; TB) could also depend on these factors, and it could be better observed under limited conditions of $\mathrm{AI}$, such as decreased sperm concentration, small or null preselection of ejaculates for any semen quality trait, or a long storage period of the AI doses. The aim of this research was to determine if an interaction existed between male genotype and the AI conditions for male effects on Fert and TB after AI was performed under different conditions. Fertility and TB were assumed to be different traits and were analyzed in 2 sets of independent analyses. In the first step, the different conditions were determined uniquely by the sperm dosage. Artificial insemination was performed at 10 and $40 \times 10^{6}$ spermatozoa $/ \mathrm{mL}$. In the second step, the different conditions were determined by all the factors involved in the AI process as a whole (conditions and duration of the storage period of the dose, genetic type of the female, and environmental conditions on the farm). Data from AI from the former experiment were analyzed with data from AI performed under different conditions. Threshold and linear 2-trait models were assumed for Fert and TB, respectively. The sperm dosage had a clear effect on Fert and TB, which favored the greater dosage $(+0.13 \%$ and +1.25 kits born, respectively). Prolificacy was more sensitive to sperm reduction than was fertility. Male heritabilities for Fert were 0.09 for both sperm dosages, and were 0.08 and 0.06 for male TB with a smaller and larger sperm dosage, respectively. No genotype $\times$ sperm dosage interaction was found. Therefore, the same response to selection to improve male Fert and TB could be achieved at any sperm concentration. However, an interaction between male genotype and the $\mathrm{AI}$ conditions as a whole seemed to exist, indicating that the AI conditions for selection for Fert and TB could be modified to maximize genetic progress. Consequently, the optimization of a breeding program for male Fert and TB under a given set of semen utilization conditions is achievable.

Key words: artificial insemination, (co)variance component, genotype $\times$ environment interaction, male fertility, male prolificacy, rabbit. 


\section{Introduction}

The outcome of mating is dependent on the contribution of the male, the female, and environmental factors (Koops et al., 1995). The effect of the number and quality of sperm involved in the fertilization process and subsequent embryogenesis is well documented (Den Daas et al., 1998; Saacke et al., 2000). However, when fertility (success or failure to conceive; Fert) and prolificacy (total number of kits born per litter; $\mathbf{T B}$ ) are evaluated after natural mating (NM) or after AI under commercial conditions, the observed variation attributable to the contribution of the male is very small or almost null (in rabbits after NM: Piles et al., 2005, 2006; in swine after AI: Van der Lende et al., 1999; Varona and Noguera, 2001). These commercial conditions are not optimal for detecting individual variation among males because the number of sperm is very large and most of the males exceed the threshold needed to reach Fert (Amann and Hammerstedt, 2002). Thus, whereas differences among males that are independent of sperm dosage are maintained, differences among males that can, at least in part, be overcome by increasing the amount of sperm are not detected (Saacke et al., 2000). Moreover, when $\mathrm{AI}$ is performed, there is a strong preselection of the ejaculates used, reducing the amount of observed variation. Concerning the masking effect of a large sperm dosage on the observed variance for male Fert and TB, the first aim of this research was to determine if an interaction existed between the male genotype and concentration of the AI dose. Other factors involved in the AI process (conditions and duration of the storage period of the dose, genetic type of the female, environmental conditions on the farm) could also lead to an interaction with the male genotype. Therefore, the second aim of this study was to investigate and quantify the interaction between male genotype and AI conditions.

\section{Materials and methods}

The research protocol was approved by the animal care and use committee of the Institut de Recerca i Tecnologia Agroalimentàries.

\section{Animals and data}

Data on male Fert and TB were analyzed from bucks belonging to a population of a paternal line selected for growth rate during the fattening period (Caldes line: Gomez et al., 2002). Data originated from 2 different sources. For data set 1, AI was performed on a commercial farm with semen from a random sample of males from the Caldes line. Doses were prepared after conducting a small preselection of the ejaculates for seminal quality traits and were stored for $24 \mathrm{~h}$ until AI was performed on crossbred females from 2 dam lines. For data set 2, AI was performed in the nucleus of selection of the Caldes line on females from the same paternal 
line. In this case, AI doses were prepared and used within 30 min after ejaculate collection, with no selection for semen quality traits.

Males from both data sets were contemporary and closely related. Bucks were bred and reared in thenucleus of selection in Caldes de Montbui (Barcelona, Spain). This farm has an insulated roof and walls and the proper cooling equipment to avoid animal exposure to extreme temperatures. After weaning at $32 \mathrm{~d}$, males were housed in collective cages of 8 individuals, with a photoperiod of $16 \mathrm{~h}$ of light/d. Animals were fed a commercial diet of rabbit pellets ad libitum $(15.5 \% \mathrm{CP}, 2.3 \%$ fat, $17.2 \%$ fiber) until d 60 . Subsequently, they were housed on the farm of the AI center (which had the same environmental conditions as the nucleus of selection and was located next to it) and were restricted to $180 \mathrm{~g} / \mathrm{d}$ of another commercial diet (16\% CP, 4.3\% fat, 17\% fiber). Fresh water was always available.

All males began training to use an artificial vagina at $4.5 \mathrm{mo}$. A homemade polyvinyl chloride artificial vagina containing water at a temperature of $50^{\circ} \mathrm{C}$ was used. One ejaculate was collected per male each week for the first $2 \mathrm{wk}$. After this period, 2 ejaculates per male were collected each week, with an interval of 30 min between collections.

\section{Preparation of the AI doses used in the experiment}

Ejaculates were stored, for no more than $15 \mathrm{~min}$ after collection, in a dry bath at $35^{\circ} \mathrm{C}$ until their evaluation for seminal quality. Ejaculates containing urine and calcium carbonate deposits were discarded, and gel plugs were removed. Individual motility of the ejaculate was measured in aliquots $(25 \mu \mathrm{L})$ under a microscope with a phase-contrast optic (Nikon, Lewisville, TX) at 400× magnification, according to a subjective scale from 0 to $5(0,1,2,3,4$, or $5=0$ to $10,<10$ to $25,<25$ to $50,<50$ to $70,<70$ to 90 , or $<90$ to $100 \%$, respectively, of the motile spermatozoa showing progressive movement; Roca et al., 2000). A small preselection of ejaculates was performed, discarding only those with individual motility scores of less than 2 and a percentage of dead spermatozoa greater than $50 \%$. After evaluation, the 2 ejaculates from each buck were pooled and diluted $(1: 1, \mathrm{vol} / \mathrm{vol})$ in a commercial saline extender for rabbit semen (Cunigel, IMV Technologies, Saint Ouen sur Iton, France), and the cell sperm concentration was measured using a sperm cell counter (NucleoCounter SP-100, ChemoMetec A/S, Allerod, Denmark). The pooled semen from each buck was divided into 2 parts and diluted to $10 \times 10^{6}$ spermatozoa/mL (referred to as type 10 doses) or $40 \times 10^{6}$ spermatozoa/mL (referred to as type 40 doses). These concentrations were chosen as a compromise between 1) the number of data per male and day necessary to separate the male effect from other random factors and to maximize the accuracy of the estimates, and 2) the difference in sperm concentrations necessary to distinguish the effects of seminal 
characteristics that could and could not be compensated for by a large number of spermatozoa in the $\mathrm{AI}$ dose. The $\mathrm{AI}$ doses were stored in straws of $0.5 \mathrm{~mL}$ at $18^{\circ} \mathrm{C}$ for $24 \mathrm{~h}$ until use.

\section{Preparation of AI doses used in the nucleus of selection of the paternal line}

Only ejaculates containing urine and calcium carbonate deposits were discarded, and gel plugs were removed. No evaluation of seminal characteristics was performed. Ejaculates were diluted 1:4 (vol/vol) in a commercial liquid extender (Galap, IMV Technologies, Saint Ouen sur Iton, France) immediately after collection with an unknown sperm concentration (referred to as type $\mathrm{N}$ doses). Artificial insemination doses of $0.5 \mathrm{~mL}$ were applied within $1 \mathrm{~h}$ after preparation.

AI

The experiment was performed from November 2006 until July 2007. Type 10 and type 40 doses from each buck were applied on 2,293 crossbreed does (Prat $\times \mathrm{V}$ lines), which were crossbred between animals from 2 maternal lines selected for litter size at weaning (V line: Estany et al., 1989; Prat line: Gomez et al., 1996). Females were reared on a commercial farm located in Montmajor (Barcelona, Spain). This farm has 2 buildings with an insulated roof and walls and systems to avoid extreme temperatures. Females had water and food ad libitum and were raised under a photoperiod of $16 \mathrm{~h}$ of light/d.

Data from the nucleus of selection of the paternal line corresponded to the period from June 2003 to November 2008. Type $\mathrm{N}$ doses were applied on 2,601 females from the same paternal line reared in the nucleus of selection described above. After weaning at $32 \mathrm{~d}$, the young females were housed together with the males in collective cages until $60 \mathrm{~d}$. Subsequently, they were placed in individual cages and restricted to $180 \mathrm{~g} / \mathrm{d}$ of a commercial diet consisting of $16 \% \mathrm{CP}, 4.3 \%$ fat, and $17 \%$ fiber. Fresh water was always available.

Both groups of females (Caldes and Prat $\times \mathrm{V}$ lines) followed a semi-intensive reproductive rhythm. The first AI occurred at approximately 4.5 mo of age, with subsequent 42 -d reproductive cycles. Two weeks before first parity, does were placed in maternal cages and fed ad libitum with the same commercial pellets.

At $48 \mathrm{~h}$ before AI, all females were treated with 15 IU of eCG (subcutaneously; Foligon, Intervet International B.V., Booxmeer, the Netherlands). Ovulation was induced immediately after AI with $0.02 \mathrm{mg}$ of gonadorelin (intramuscularly; Fertagyl, Intervet Internacional B.V.).

Pregnancy was diagnosed by abdominal palpation $14 \mathrm{~d}$ after AI. The assigned fertility score was 1 when the female was diagnosed as pregnant and was 0 otherwise. These fertility data 
were confirmed at parturition. Therefore, errors in diagnosis of gestation were possible only in the case of females that died before the date of parturition, which represented less than $1 \%$ of all records. Prolificacy was defined as the total number of kits born per litter and was recorded at kindling. Table 4.1 shows the summary statistics for male fertility, $\mathbf{F}_{i}$, and prolificacy, $\mathbf{T B}_{\boldsymbol{i}}$, for $i=10,40$, and $\mathrm{N}$, corresponding to AI performed with type 10 , type 40 , and type $\mathrm{N}$ doses, respectively. The pedigree included 1,437 individuals.

Table 4.1. Summary statistics for fertility $\left(F_{i}\right)$ and number of total kits born (TB ${ }_{i}$ across the 3 different types of AI doses $\left(i=10^{1}, 40^{2}, N^{3}\right)$

\begin{tabular}{|c|c|c|c|}
\hline \multicolumn{4}{|l|}{ Fertility data } \\
\hline & $\mathrm{F}_{10}$ & $\mathrm{~F}_{40}$ & $\mathrm{~F}_{\mathrm{N}}$ \\
\hline No. of males & 248 & 232 & 300 \\
\hline No. of females & 1,777 & 1,660 & 2,601 \\
\hline Mean of No. of records per male & 14.6 & 12.9 & 21.8 \\
\hline Mean of No. of records per female & 2.0 & 1.8 & 2.5 \\
\hline No. of data & 3,617 & 2,996 & 6,543 \\
\hline \multicolumn{4}{|l|}{ Prolificacy data } \\
\hline & $\mathrm{TB}_{10}$ & $\mathrm{~TB}_{40}$ & $\mathrm{~TB}_{\mathrm{N}}$ \\
\hline No. of males & 202 & 206 & 290 \\
\hline No. of females & 1,129 & 1,159 & 1,786 \\
\hline Mean of No. of records per male & 8.2 & 8.4 & 14.9 \\
\hline Mean of No. of records per female & 1.5 & 1.5 & 2.4 \\
\hline No. of data & 1,647 & 1,732 & 4,325 \\
\hline
\end{tabular}

$10=$ AI with $24-\mathrm{h}$ stored doses with $10 \times 10^{6}$ spermatozoa $/ \mathrm{mL}$ applied on crossbred females from 2 maternal lines on a commercial farm.

$40=$ AI with $24-\mathrm{h}$ stored doses with $40 \times 10^{6}$ spermatozoa $/ \mathrm{mL}$ applied on crossbred females

from 2 maternal lines on a commercial farm.

${ }^{3} \mathrm{~N}=$ AI with fresh doses with an unknown sperm concentration applied on purebred females

from a paternal line in a nucleus of selection.

\section{Models and Statistical Analysis}

Fertility and prolificacy traits were analyzed independently, and for each of these traits, the following analyses were performed. First, insemination outcomes from data set 1, obtained using type 10 and type 40 doses, were considered different traits: $\mathbf{F}_{\mathbf{1 0}}$ and $\mathbf{F}_{\mathbf{4 0}}$ for fertility, and $\mathbf{T B}_{10}$ and $\mathbf{T B}_{40}$ for prolificacy. To determine the effect of AI dose concentration and its interaction with male genotype, 2 bivariate models were used to analyze Fert and TB separately. The effect of sperm dosage was obtained from the estimated marginal posterior distribution (EMPD) for the difference between the overall means of both traits. Second, the outcomes from data set 1 , obtained with type 10 and type 40 doses, were combined and treated as 1 trait for fertility $\left(\mathbf{F}_{\mathrm{EXP}}\right)$ and prolificacy $\left(\mathbf{T B}_{\mathrm{EXP}}\right)$. Each of these 2 traits was analyzed jointly with the corresponding response from data set 2, obtained using type $\mathrm{N}$ doses $\left(\mathbf{F}_{\mathbf{N}}\right.$ or $\mathbf{T B}_{\mathrm{N}}$ ), via a bivariate model with the specific objective of assessing the interaction of genotype $\times$ AI conditions. 


\section{Analysis of Fertility}

We assumed a threshold model for Fert. This model postulates that the observed binary responses are indicators of an underlying continuous random variable $\mathbf{l}$ (liability) and a fixed threshold that divides the continuous scale into 2 intervals that delimit the 2 response categories (Wright, 1934). Procedures developed by Sorensen et al. (1995), based on Markov chain Monte Carlo methods, allow the analysis of categorical traïts using this model. In matrix notation, the following model was assumed:

$\mathbf{l}=\mathbf{X} \boldsymbol{\beta}+\mathbf{Z}_{1} \mathbf{u}_{m}+\mathbf{Z}_{2} \mathbf{p}_{m}+\mathbf{Z}_{3} \mathbf{p}_{f}+\mathbf{Z}_{4} \mathbf{p}_{m d}+\mathbf{e}$

where $\mathbf{l}$ is the vector of liability for F; $\boldsymbol{\beta}$ is the vector of systematic effects; $\mathbf{u}_{\mathrm{m}}$ is the vector of male genetic additive effects; $\mathbf{p}_{\mathrm{m}}$ is the vector of male nonadditive genetic plus permanent environmental effects; $\mathbf{p}_{\mathrm{f}}$ is the vector of female effects; $\mathbf{p}_{\mathrm{md}}$ is the vector of permanent environmental effects resulting from the combination between the male and the day on which the AI was performed, and $\mathbf{e}$ is the residual. $\mathbf{X}$ and $\mathbf{Z}_{i}(i=1, \ldots, 4)$ are incidence matrices relating the variable $l$ to the systematic, genetic, and permanent environmental effects described above. The definition and number of levels of systematic effects for Fert included in the different models are shown in Table 4.2. The systematic effect resulting from the combination of buck age and building on the farm was defined as the result of combining $20-\mathrm{d}$ intervals from 5 to 9 mo of age and the 2 buildings on the commercial farm where the AI were performed. The systematic effect of buck age was defined as 3.5-mo intervals from 4.5 to 32 mo of age. 


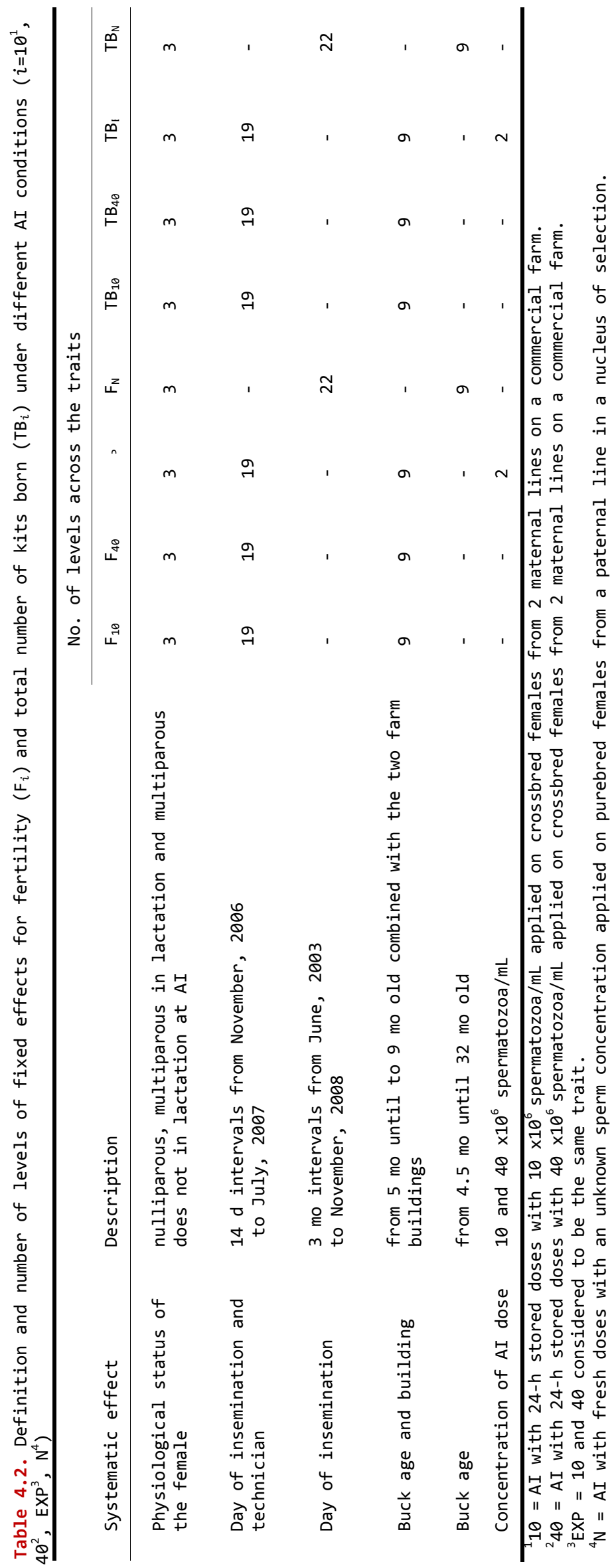


The thresholds and residual variances were fixed at 0 and 1, respectively, and the covariance between residuals, regardless of the trait, was always set to 0 because the observations were measured on different does. A Bayesian approach was adopted for inference. The prior distributions for the parameters of the model were $p(\boldsymbol{\beta}) \sim k$;

$$
\begin{array}{ll}
p\left(\mathbf{u}_{m} \mid \mathbf{G}\right) \sim N(\mathbf{0}, \mathbf{G} \otimes \mathbf{A}) ; & p\left(\mathbf{p}_{m} \mid \mathbf{P}_{m}\right) \sim N\left(\mathbf{0}, \mathbf{P}_{m} \otimes \mathbf{I}\right) ; \\
p\left(\mathbf{p}_{f} \mid \mathbf{P}_{f}\right) \sim N\left(\mathbf{0}, \mathbf{P}_{f} \otimes \mathbf{I}\right) ; & p\left(\mathbf{p}_{m d} \mid \mathbf{P}_{m d}\right) \sim N\left(\mathbf{0}, \mathbf{P}_{m d} \otimes \mathbf{I}\right), \text { where k }
\end{array}
$$

is a constant, $\mathbf{A}$ is the numerator relationship matrix, $\mathbf{I}$ is the identity matrix, $\mathbf{G}$ is the additive genetic (co)variance matrix, $\mathbf{P}_{\mathrm{m}}$ is the (co)variance matrix of male nonadditive genetic plus permanent environmental effects, $\mathbf{P}_{\mathrm{f}}$ is the (co)variance matrix of female effects, $\mathbf{P}_{\mathrm{md}}$ is the (co)variance matrix of permanent environmental effects resulting from the combination of male and day of AI.

Table 4.3 shows the structure of matrices used in the analysis. In the analyses of traits after AI was conducted with different sperm dosages, a correlation was considered to exist between the 2 traits for all permanent effects, whereas in the analysis of traits after AI under different conditions, all the random effects were considered uncorrelated, except the male additive effect, because different groups of males from the same population were used and females were of a different genetic type. Given the complexity of the model, a simulation study using the same data structure and pedigree as the real data used for the Fert experiment confirmed the ability of the statistical procedure to recover the simulated parameters (results not shown).

\section{Analysis of Prolificacy}

Total number of kits born per litter was considered a continuous trait and was analyzed with the same linear model used for the liability of Fert. The same assumptions for the structure of (co)variances of all random effects were made (Table 4.3), except for the residual (co)variance matrix, which was, in this case, a diagonal matrix with unknown elements. The number of levels of systematic effects included in the model for each trait is also shown in Table 4.2 .

Prior distributions for systematic and random effects and (co)variance components were the same for Fert but with different hyper-parameters. The prior distribution for the residuals was $p(\mathbf{e} \mid \mathbf{R}) \sim N(\mathbf{0}, \mathbf{R} \otimes \mathbf{I})$, and bounded uniform priors were assumed for the elements of $\mathbf{R}$. 
Table 4.3. Structure of the (co)variance matrices assumed for fertility and total number of kits born in the 2 groups of analysis ${ }^{1}$

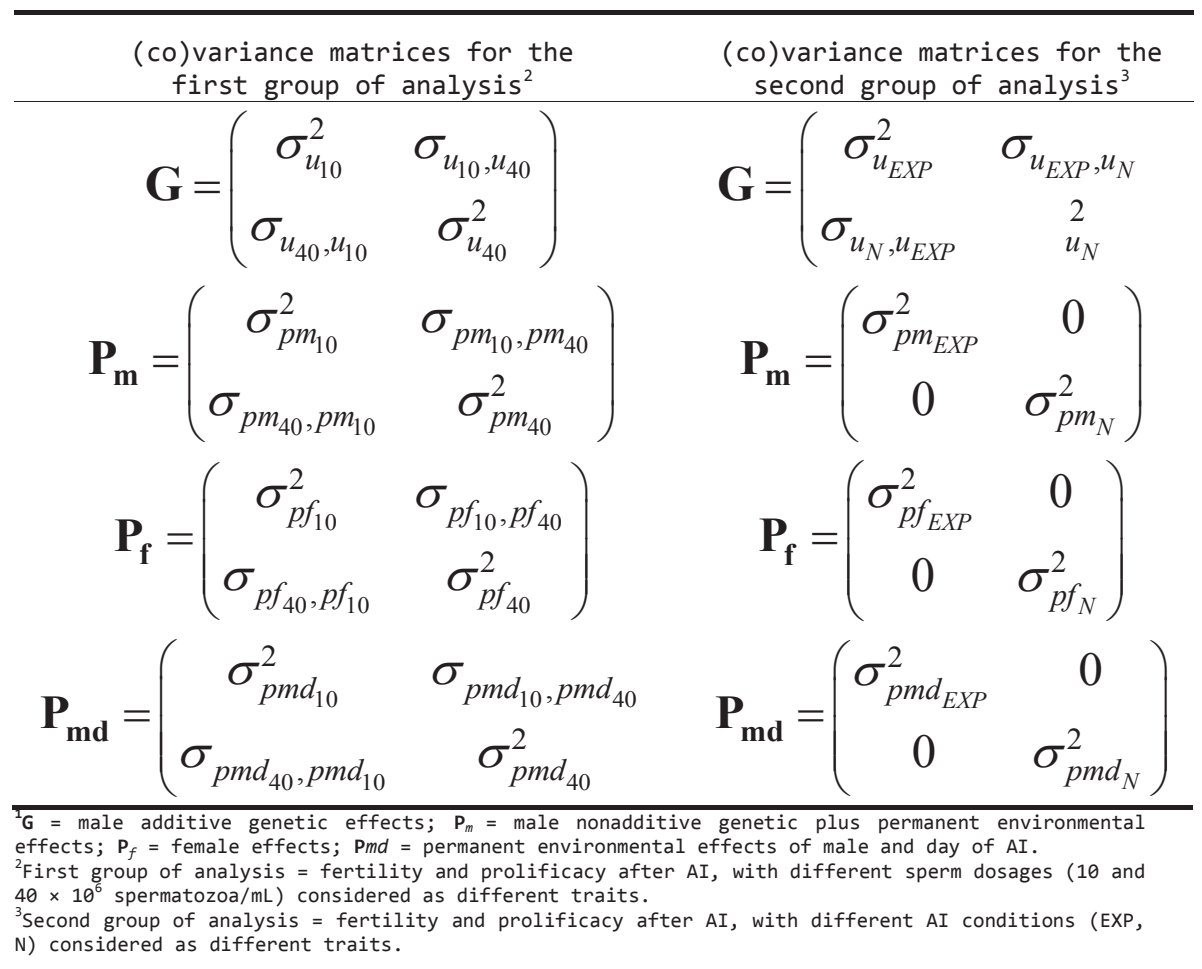

\section{The Gibbs Sampler}

The marginal posterior distributions of the variables of interest were approximated using the Gibbs sampler algorithm. Conditional distributions of the model parameters that are necessary for its implementation can be found in the report by Sorensen and Gianola (2002). Single chains of 500,000 iterations were run for all the analyses. The first 50,000 iterations of each chain were discarded, and samples of the parameters of interest were saved every 25 rounds. The number of discarded samples was, in all cases, much larger than the required burn-in determined by using the procedures of Raftery and Lewis (1992) and Geweke (1992). The sampling variance of the chains was obtained by computing Monte Carlo SE (Geyer, 1992).

\section{The Variance of the Genotype $\times$ Environment Interaction}

A genotype $\times$ environment interaction $(\mathbf{G} \times \mathbf{E})$ appears when there are differences in environmental sensitivity between individuals. By treating the observations under different environments or conditions as different traits, the genetic correlation $\left(\mathbf{r}_{\mathrm{g}}\right)$ measures the possible existence of $\mathrm{G} \times \mathrm{E}$ caused by a reranking of the genotypes by the expression of their phenotypes across environments, whereas the difference in magnitude of the genetic variances $\left(\sigma_{G_{i}}^{2}\right)$ across environments measures the possible existence of G $\times$ E caused by a scale effect (Kolmodin, 2003). The posterior distributions of the 
interaction variance $\left(\sigma_{G x E}^{2}\right)$ for Fert and TB were estimated from the samples of genetic variances and covariances according to the following formula (Mathur, 2002):

$\sigma_{\mathrm{GxE}}^{2}=\frac{1}{2}\left(\sigma_{\mathrm{G}_{1}}-\sigma_{\mathrm{G}_{2}}\right)^{2}+\sigma_{\mathrm{G}_{1}} \sigma_{\mathrm{G}_{2}}\left(1-\mathrm{r}_{\mathrm{g}}\right)$

where $\sigma_{G_{i}}$ is the genetic SD in environment $i$.

\section{Results and discussion}

\section{Effect of Concentration of the AI Dose and Its Interaction with Male Genotype}

\section{Fertility}

The overall means (SD) of the EMPD for $F_{10}$ and $F_{40}$ were $0.42(0.04)$ and $0.55(0.04)$, respectively. This result indicates a clear effect of sperm dosage on Fert, as shown in Figure 4.1 (approximately 31\% of the overall mean of the EMPD for $\mathrm{F}_{10}$ ). This illustrates that the effect of deficiencies in some seminal characteristics (viability, motility, morphology, and other unknown functional and molecular traits; Saacke et al., 2000) can be compensated for by increasing the amount of sperm. In a previous study, the sperm concentration of the ejaculate (which was the maximum value for the dose concentration) in this line was estimated to be $252 \times 10^{6}$ spermatozoa/mL (Garcia-Tomas et al., 2006), and the Fert rate after NM with purebred females of the same line was 80.5\% (Piles et al., 2005). Therefore, in this experiment, a sperm dosage of $40 \times 10^{6}$ spermatozoa/ $\mathrm{mL}$ did not seem to be large enough to compensate for the deficiencies in sperm characteristics, precluding access of sperm to the ovum or their ability to engage the ovum sufficiently to initiate fertilization and block polyspermy when homospermic doses were used. In addition, a greater dilution of the ejaculate implies a greater dilution of the seminal plasma, which has been shown to have a role in promoting Fert. The seminal plasma is the vehicle for the spermatozoa, stimulating their motility and protecting membrane integrity and functionality (Maxwell and Johnson, 1999). The effect of sperm dosage could be nonlinear; moreover, there could be an effect of other factors related to the AI process (different from the semen characteristics) that could explain differences in conception rate after AI with a large sperm dosage and the same ratio after NM. Individual differences in factors with an effect that cannot be compensated for with a large number of spermatozoa (traits affecting embryo quality, such as defective chromatin; Saacke et al., 2000) would explain the small variation attributable to male Fert after NM. 

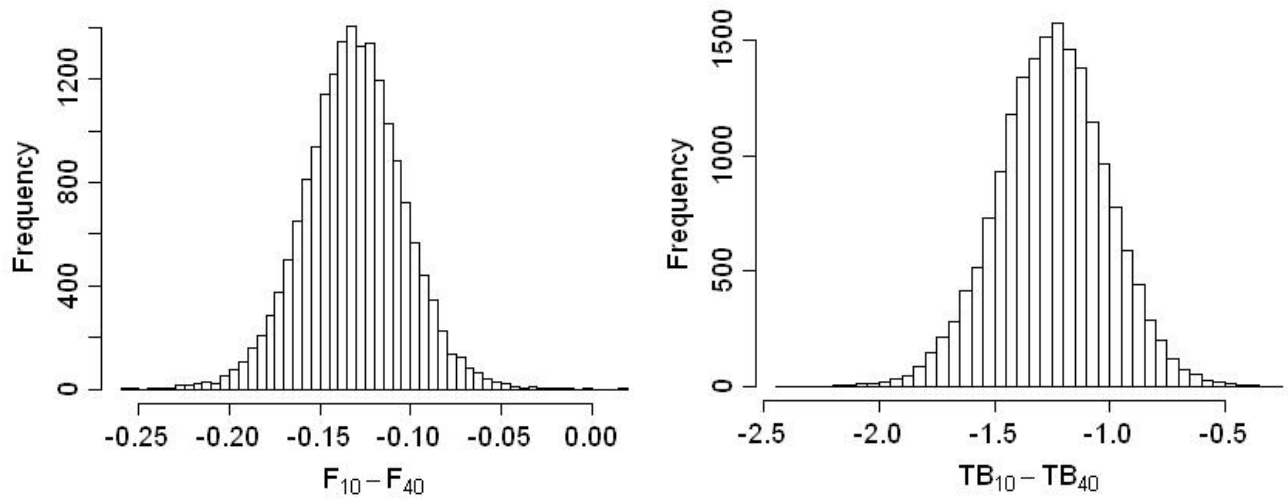

Figure 4.1. Estimated marginal posterior distribution of the difference between fertility in the observed scale $\left(F_{i}\right)$ and total number of kits born (TB ${ }_{i}$ at 2 different sperm concentrations of the AI dose $(i=10,40) .10=A I$ with $24-h$ stored doses with 10 $\times 10^{6}$ spermatozoa/mL applied on crossbreed females from 2 maternal lines on a commercial farm. $40=A I$ with $24-\mathrm{h}$ stored doses with $40 \times 10$ spermatozoa/mL applied on crossbreed females from 2 maternal lines on a commercial farm.

The EMPD corresponding to the ratios between variance components for $\mathrm{F}_{10}$ and $\mathrm{F}_{40}$ are summarized in Table 4.4. Although imprecise, heritabilities were similar for $F_{10}$ and $F_{40}$, and both were greater than the corresponding value after NM (0.013; Piles et al. 2005), with a probability of 95 and $99 \%$ for $\mathrm{F}_{10} 10$ and $\mathrm{F}_{40}$, respectively. This suggests that genetic variance after NM could mainly be due to individual genetic variation in deficiencies of semen characteristics, with an effect that could not be compensated for by a large sperm dosage. Such characteristics are associated with the ability of the sperm to maintain the fertilization process or subsequent embryogenesis once initiated. However, the genetic variance for male Fert after AI was due to individual genetic variation in any kind of semen characteristic (seminal deficiencies that were and were not able to be compensated for by increasing the amount of sperm). Variance in the genotype $\times$ sperm dosage interaction was small. In fact, it represented only $8.1 \%$ of the additive variance. This is because the genetic variance was the same for both traits and their genetic correlation was almost 1 (Table 4.5). This means that mostly the same genes were affecting $F_{10}$ and $F_{40}$; thus, the responses to selection for increased male Fert obtained after AI within this range of sperm dosage would be the same. In addition, the proportion of the response to selection for 1 trait that could be expected for the other trait, as a correlated response, would be large. Thus, within the studied range of sperm dosage, selection to improve male Fert after AI could be performed at any sperm dosage and could have a greater response to selection than selection for male Fert after NM. Thus, although there is an effect of sperm dosage on Fert, there is a negligible change in the magnitude of the male genetic variance across sperm dosages. This indicates that almost no genetic control is involved in the effect of semen characteristics (as a whole) on Fert after AI that could be compensated for by increasing the sperm dosage. Thus, if the objective is to improve male Fert through indirect selection for semen quality, with no restriction on dose concentration, the selection criteria should be characteristics whose deficiencies could not be compensated for 


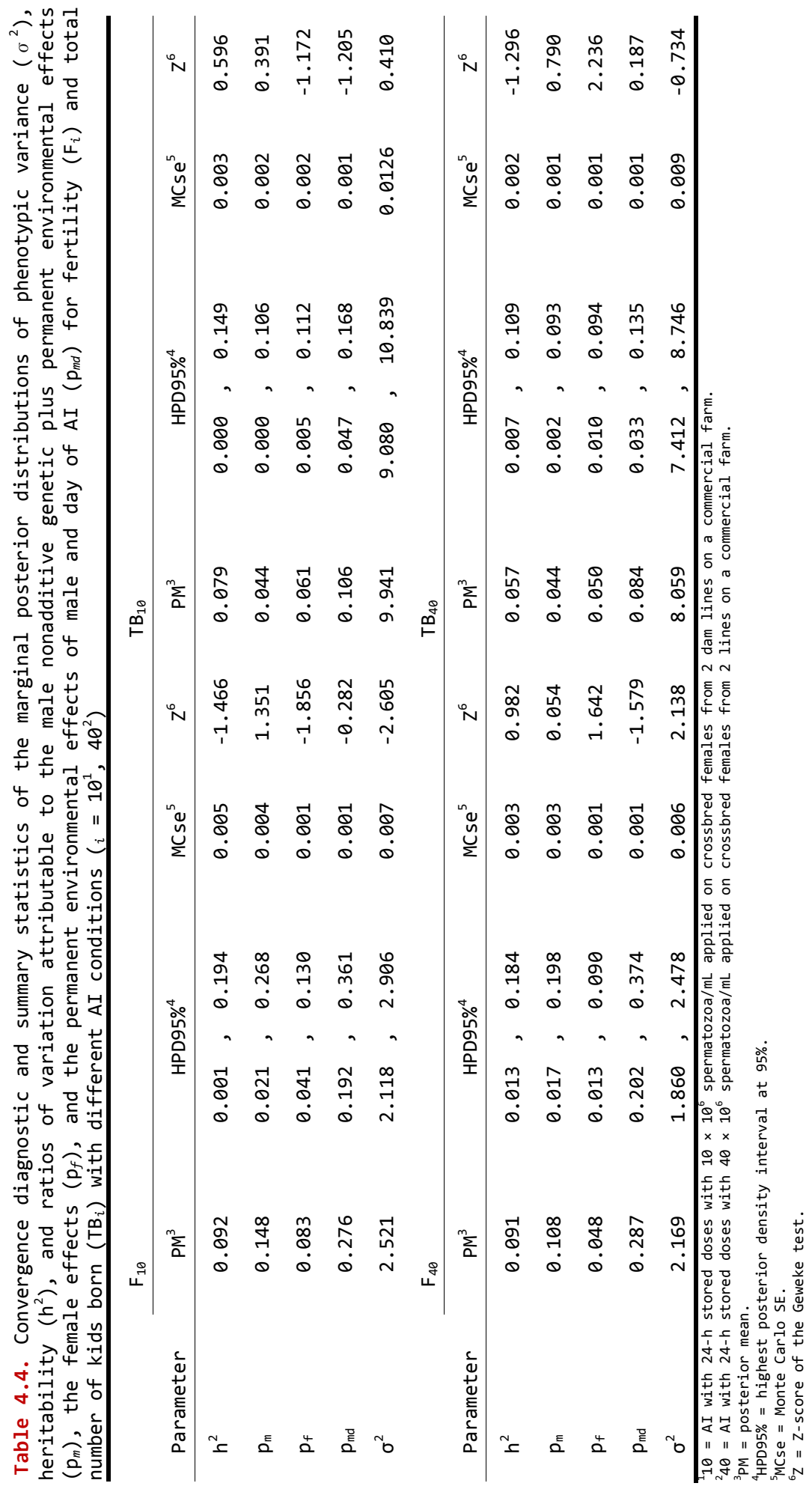


by increasing the sperm dosage. However, if the objective is to optimize the use of ejaculates to obtain a greater number of doses for $\mathrm{AI}$, the selection criteria should be semen quality traits whose deficiencies could be compensated for by increasing the sperm dosage or both types.

The most important environmental factor affecting both traits was the permanent environmental effect of the combination of male and day on which the AI was performed. This result highlights the sensitivity of male Fert to environmental conditions during ejaculate collection, dose preparation, and storage. The correlation between the 2 traits for permanent effects was $0.89,0.85$, and 0.85 for $\mathbf{p}_{\mathrm{f}}, \mathbf{p}_{\mathrm{m}}$, and $\mathbf{p}_{\mathrm{md}}$, respectively.

Table 4.5. Convergence diagnostic and summary statistics of the marginal posterior distribution of genetic correlation $\left(r_{g}\right)$ and variance of the genotype per type of AI dose interaction $\left(\sigma_{G \times E}^{2}\right)$ for fertility $\left(F_{i}\right)$ and total number of kids born (TB ${ }_{i}$ ) at different $A I$ conditions $\left(=10,{ }^{1} 40,{ }^{2} \operatorname{EXP}^{3} \mathrm{~N}^{4}\right)$

\begin{tabular}{|c|c|c|c|c|c|c|c|}
\hline Parameter & Traits & $\mathrm{PM}^{5}$ & \multicolumn{3}{|c|}{ HPD95\% ${ }^{6}$} & $M C \operatorname{se}^{7}$ & $z^{8}$ \\
\hline \multirow{4}{*}{$\mathrm{rg}$} & $F_{10}, F_{4 \theta}$ & 0.851 & 0.475 & , & 1.000 & 0.017 & -0.573 \\
\hline & $F_{\text {EXP }}, F_{N}$ & -0.038 & -0.999 & , & 0.891 & 0.027 & 0.952 \\
\hline & $\mathrm{TB}_{10}, \mathrm{~TB}_{40}$ & 0.865 & 0.499 & , & 1.000 & 0.027 & -0.905 \\
\hline & $\mathrm{TB}_{\mathrm{EXP}}, \quad \mathrm{TB}_{\mathrm{N}}$ & -0.404 & -0.999 & , & 0.541 & 0.045 & -4.758 \\
\hline \multirow{4}{*}{$\sigma_{\mathrm{GXE}}^{2}$} & $F_{10}, F_{40}$ & 0.035 & 0.000 & , & 0.093 & 0.002 & 0.206 \\
\hline & $F_{E X P}, F_{N}$ & 0.094 & 0.000 & , & 0.214 & 0.003 & -1.222 \\
\hline & $\mathrm{TB}_{10}, \mathrm{~TB}_{40}$ & 0.103 & 0.001 & , & 0.293 & 0.009 & 2.922 \\
\hline & $\mathrm{TB}_{\mathrm{EXP}}, \mathrm{TB}_{\mathrm{N}}$ & 0.459 & 0.049 & , & 0.870 & 0.013 & 1.753 \\
\hline
\end{tabular}

$10=$ AI with $24-\mathrm{h}$ stored doses with $10 \times 10^{6}$ spermatozoa/mL applied on crossbred females from 2 maternal

lines in a commercial farm.

${ }^{2} 40=$ AI with 24 -h stored doses with $40 \times 10^{6}$ spermatozoa/mL applied on crossbred females from 2 maternal

lines in a commercial farm.

${ }^{3} \operatorname{EXP}=10$ and 40 considered to be the same trait.

${ }^{4} \mathrm{~N}=$ AI with fresh doses with unknown sperm concentration applied on purebred females from a paternal line in

a nucleus of selection.

${ }^{5} \mathrm{PM}=$ posterior mean.

${ }^{6} \mathrm{HPD} 95 \%$ = highest posterior density interval at $95 \%$.

${ }^{7} \mathrm{MCse}=$ Monte Carlo SE.

${ }^{8} \mathrm{Z}=\mathrm{Z}$-score of the Geweke test.

\section{Prolificacy}

The overall means (SD) of the EMPD for $\mathrm{TB}_{10}$ and $\mathrm{TB}_{40}$ were $7.25(0.30)$ and $8.50(0.24)$, respectively. This was an increase of $17.2 \%$ in $\mathrm{TB}$ with the increase in dose concentration. Thus, the effect of sperm dosage also seemed to be expressed as the number of fertilized ova and developed embryos (Figure 4.1). Nadir et al. (1993) suggested that by increasing the number of spermatozoa at the site of fertilization, the sperm would increase their competition to fertilize the ovum, resulting in a greater probability of the ovum being fertilized by normal spermatozoa and thus ensuring the success of the fertilization event as well as subsequent normal embryonic development. A summary of the posterior distributions of the variance components and heritabilities for $\mathrm{TB}_{10}$ and $\mathrm{TB}_{40}$ is presented in Table 4.4. The heritability of male litter size after AI was greater than the estimated ratios of male permanent variance with respect to the phenotypic variance after NM in 3 maternal lines of rabbits, which ranged from 
0.02 to 0.03 (Piles et al., 2006). Similarly, in swine, a very small boar effect has been found in several studies (See et al., 1993; Van der Lende et al., 1999; Hamann et al., 2004). The additive variances for $\mathrm{TB}_{10}$ and $\mathrm{TB}_{40}$ were not different. The genetic correlation between the 2 traits was near 1 (Table 4.5), and the genotype $\times$ sperm dosage interaction was almost $0(1.1 \%$ of the phenotypic variance). The conclusions regarding the success of the selection for improving TB through the male genetic effect would be the same as those described above for Fert. No differences were found in the ratios of phenotypic variance concerning the permanent effects between $\mathrm{TB}_{10}$ and $\mathrm{TB}_{40}$. The permanent environmental effect resulting from the combination between male and timing of AI was also the most important effect for both traits. The correlations between traits for $\mathbf{p}_{\mathrm{f}}$ and $\mathbf{p}_{\mathrm{m}}$ were 0.75 and 0.72 , respectively, but surprisingly, the correlation was null for $\mathbf{p}_{\mathrm{md}}$.

Comparison between the effect of sperm dosage in Fert and prolificacy

To compare the effect of sperm dosage across traits regardless of their units of measure, the EMPD of the ratio between the overall mean of the traits with different sperm dosages were obtained for Fert and TB. Prolificacy was $10 \%$ more sensitive to the reduction in sperm concentration in the AI dose than was Fert (Figure 4.2). This could be explained by the fact that more sperm are needed to obtain a greater number of kits, whereas only 1 capable spermatozoid could be enough for conception. Brun et al. (2002) used homospermic AI doses in rabbits and concluded that kindling rate seemed to depend on qualitative and quantitative seminal traits, whereas TB seemed to be more dependent on quantitative traits such as concentration. In the pig, Alm et al. (2006) found that although a remarkable reduction in farrowing rate was observed with a decrease in AI dose concentration, litter size was more sensitive to this reduction. Xu et al. (1998) found no reduction in farrowing rate when sperm concentration was reduced; however, they did find a reduction in litter size. 

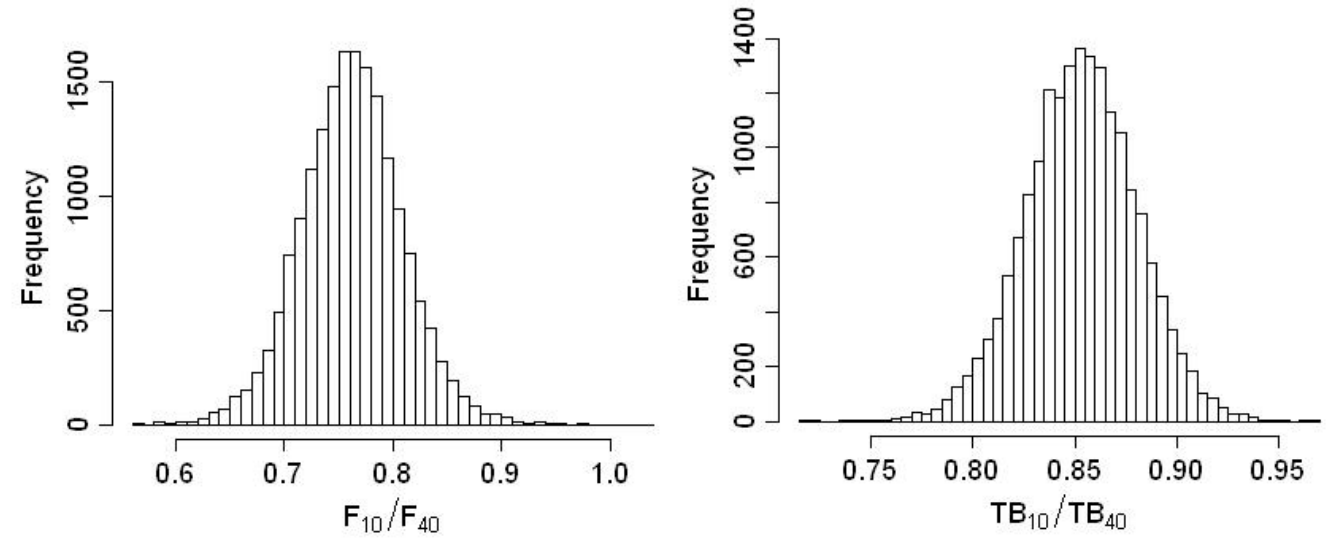

Figure 4.2. Estimated marginal posterior distribution of ratio between fertility in the observed scale $\left(F_{i}\right)$ and total number of kits born (TBi) at 2 different sperm concentrations of the AI dose $(i=10,40) .10=$ AI with $24-\mathrm{h}$ stored doses with $10 \times 10^{6}$ spermatozoa/mL applied on crosbreed females from 2 maternal lines on a commercial farm; $40=$ AI with $24-h$ stored doses with $40 \times 10^{6}$ spermatozoa/mL applied on crosbreed females from 2 maternal lines on a commercial farm.

Although the male genetic effect was of the same magnitude for Fert and TB, all permanent environmental factors related to the male were important for Fert after AI but had little influence on TB under the same conditions. This fact shows that permanent environmental factors related to the male, including those related to dose preparation and conservation, were important in the success or failure of an insemination, but once conception was reached, the contribution of the male in the number of embryos that developed until birth was very limited. Thus, TB seems to depend more on the female because it exerts a long-term effect on the formation of viable offspring.

\section{Effect of AI conditions and their interaction with male genotype}

From the previous results, it was found that under the conditions of this experiment, sperm dosage was not the factor that could explain eventual differences in male genetic additive variance. Additive variances different from those observed in this experiment have been estimated in the same paternal line after NM and after AI with other conditions (Piles et al., 2005). Thus, other factors related to the AI process could be responsible for differences in male additive variance. The following analysis aimed to answer the question of whether there was any interaction between the male genotype and other factors involved in the AI process as a whole, such as the timing and storage conditions of the AI doses, female genotype, or the environment. Conditions for dose preparation and $\mathrm{AI}$ in the nucleus of selection of the Caldes line were different from those used to obtain the experimental data on Fert and TB. Therefore, data coming from the AI performed in the nucleus of selection were analyzed in a 2-trait 
model with data coming from the AI performed in that experiment. To do that, the experimental data on Fert and TB obtained after AI with different sperm concentrations were grouped into a unique type of data named $\mathrm{F}_{\mathrm{EXP}}$ and $\mathrm{TB}_{\mathrm{EXP}}$ because they were established from the previous results such that the outcomes of AI with both types of doses could be considered the same trait.

\section{Fertility}

The EMPD corresponding to the ratios between variance components for $F_{\text {EXP }}$ and $F_{N}$ are summarized in Table 4.6. The estimates of genetic parameters were not precise, but there was some evidence of an interaction between male genotype and AI conditions. There could be a scale effect because of differences in the magnitude of the additive variances (the probability of the ratio between both male additive variances of being greater than 1.25 was 83\%). In addition, the genetic correlation between the 2 traits could be said to be different from 1 because the probability of being less than 0.75 was $90 \%$. The existence of this interaction would indicate that there could be genetic differences among males, at least in part because of differences in the capacity of the AI doses to maintain characteristics of the semen after a storage period under certain conditions. Thus, if this were confirmed, it could be possible to improve dose conservation in the AI centers by genetic selection of the paternal line, leading to a more efficient use of the bucks in the AI center. To do that, AI conditions that give the maximum genetic progress could be chosen to optimize the breeding program for male Fert under given conditions of semen utilization. This could be achieved by expressing the genetic progress in some conditions as a correlated response to selection in other conditions and then comparing the genetic progress from selection under different conditions (Kolmodin, 2003). Male permanent environmental effects were much greater for $\mathrm{F}_{\mathrm{EXP}}$ than for $\mathrm{F}_{\mathrm{N}}$. The ratio of this variance component to the total phenotypic variance was approximately 3 times greater for the first trait than for the second one, and the probability of a positive value for the difference between the corresponding variances for both traits was $97 \%$. Similarly, the magnitude of the environmental effects resulting from the combination of male and day of AI was greater for $F_{\text {EXP }}$ than for $F_{N}$ (the probability of a positive value for the difference between the corresponding variances for both traits was 100\%). This factor encompasses all the environmental effects that have in common the doses of only 1 male on a specific day, which are more important the longer the time that elapses between dose preparation and application. The variation in this factor includes the variation in seminal characteristics between different ejaculates from the same male (Garcia-Tomas et al., 2006) and the variation originating from all the handling processes in the AI center during the preparation and conservation of the AI doses until the time of insemination. As long as the conservation time of the AI doses increases, there is an increase in the oxidative processes derived by the metabolic 
activity of the spermatozoa, which results in a decrease in the fertilizing ability of the AI dose (Vishwanath and Shannon, 1997; Castellini et al., 2000). In rabbits, several authors have noted that time and storage conditions cause a decrease in sperm quality (Rosato et al., 2006) and also in Fert and TB (Lopez et al., 1996; Roca et al., 2000). Farrell et al. (1993) indicated in their study the need for rapid and careful handling of sperm so as not to compromise the fertilizing ability of the rabbit AI doses. They also indicated that variation caused by manipulation of the sperm in preparing, storing, and applying the AI doses was one of the most important factors explaining the low prediction capacity of male reproductive performance based on semen quality traits. 


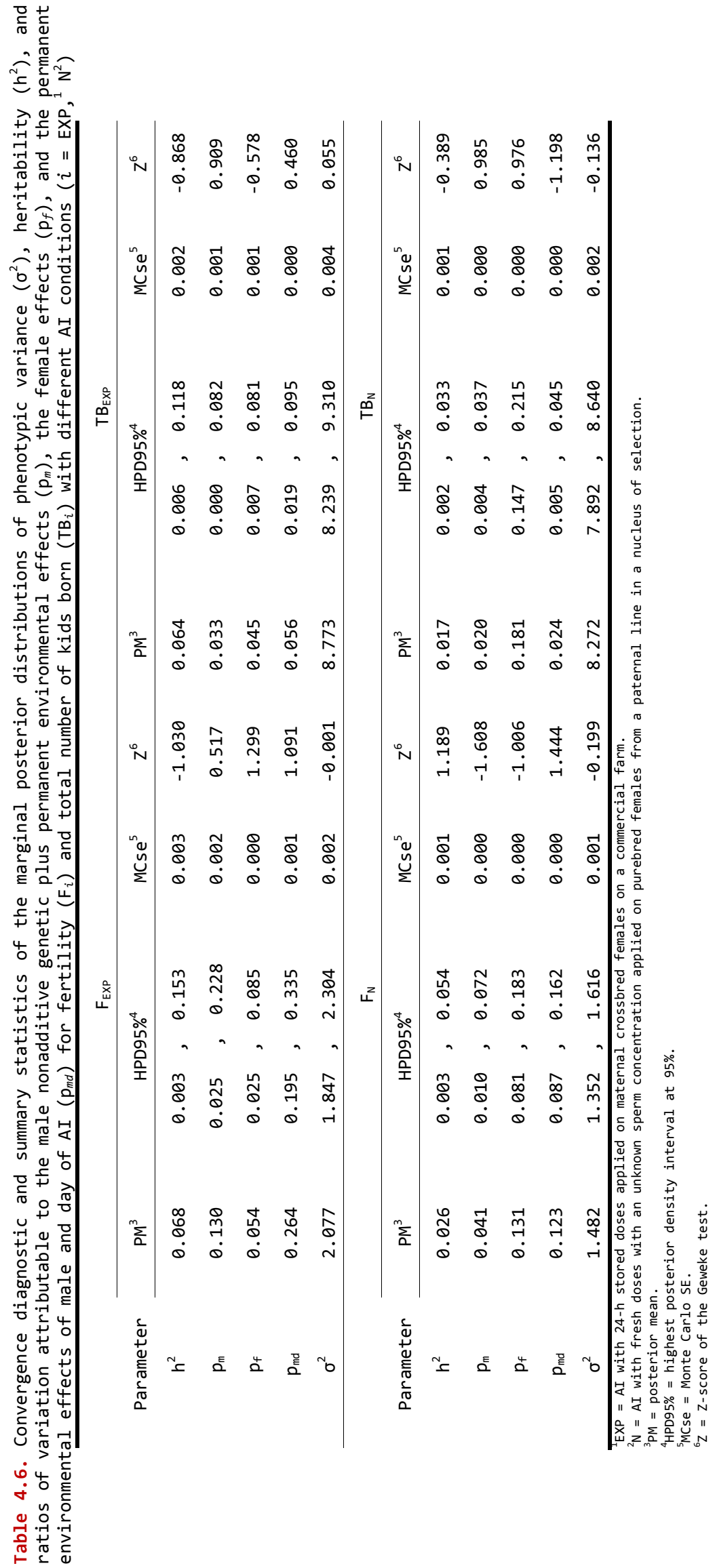




\section{Prolificacy}

Table 4.6 shows the EMPD corresponding to the ratios between variance components for $\mathrm{TB}_{\mathrm{EXP}}$ and $\mathrm{TB}_{\mathrm{N}}$.

Permanent male effects were greater after $\mathrm{AI}$ (for both traits, $\mathrm{TB}_{\mathrm{EXP}}$ and $\mathrm{TB}_{\mathrm{N}}$ ) than the corresponding values obtained for litter size after NM (Piles et al., 2006). The permanent effect attributable to the female was almost 4 times smaller for animals on the commercial farm, which were crossbred, than for those in the nucleus, which were purebred. The ratio of the variance of the interaction to the average means of the EMPD for additive variances was 1.30 (Table 4.5). This was due to the difference between the male additive variance for $\mathrm{TB}_{\mathrm{EXP}}$ and the same variance component for $\mathrm{TB}_{\mathrm{N}}$ (the probability of the ratio between them being greater than 1.25 was equal to $87 \%$ ). It was also due to a genetic correlation that could be different from 1 (the probability of the genetic correlation between the 2 traits being less than 0.75 was $100 \%)$. Here, the same conclusions could be drawn for male TB with respect to selection for male Fert according to the evidence of an interaction for genotype $\times$ AI conditions.

In a prolific species, litter size is one of the most economically important traits and is the most common selection criterion of the maternal lines. In most of the breeding programs, selection for this trait is performed with consideration only for the female. However, if the male additive variance is greater under limited conditions of AI than under conditions of AI of the nucleus of selection, the response to selection for litter size could be improved by selection based on an index that includes the female EBV predicted under the nucleus conditions and the male EBV predicted from data coming from AI.

\section{Conclusions}

There was a clear effect of sperm concentration on male Fert and TB; however, almost no genetic determinism was involved in this effect. Therefore, within the range of sperm dosage used in this study, selection to improve male Fert and TB after AI with stored doses could be done at any seminal concentration. Under these conditions, response to selection could be greater than the expected response after NM or AI with fresh doses because the male additive variance obtained for both traits in this study was greater than the corresponding values obtained in the other conditions. On the other hand, an interaction could exist between the male genotype and AI conditions, such as the time and storage conditions of the AI doses, the female genotype, or the environment. The existence of this interaction also implies that the conditions that give the maximum genetic progress could be chosen to optimize the breeding program for male Fert and TB under given conditions of semen utilization. Moreover, the response to selection for Fert and TB could be improved by including the male additive effect 
predicted from information obtained from AI performed under limited AI conditions. Finally, if part of the interaction between the male genotype and AI conditions is due to the effect of time and storage conditions of the AI doses, then any existing differences among males in the ability to maintain seminal characteristics after storage might also result in differences in their fertilization potential. Thus, it could be possible to change the sensitivity of sperm to conservation with genetic selection.

\section{Literature cited}

Alm, K., O. A. T. Peltoniemi, E. Koskinen, and M. Andersson. 2006. Porcine field fertility with two different insemination doses and the effect of sperm morphology. Reprod. Domestic Anim. 41:210-213.

Amann, R. P., and R. H. Hammerstedt. 2002. Detection of differences in fertility. J. Androl. 23: 317-325.

Brun, J. M., M. Theau-Clement, and G. Bolet. 2002. The relationship between rabbit semen characteristics and reproductive performance after artificial insemination. Anim. Reprod. Sci. 70:139-149.

Castellini, C., P. Lattaioli, M. Moroni, and A. Minelli. 2000. Effect of seminal plasma on the characteristics and fertility of rabbit spermatozoa. Anim. Reprod. Sci. 63:275-282.

Den Daas, J. H. G., G. De Jong, L. Lansbergen, and A. M. Van Wagtendonk-De Leeuw. 1998. The relationship between the number of spermatozoa inseminated and the reproductive efficiency of individual dairy bulls. J. Dairy Sci. 81:1714-1723.

Estany, J., M. Baselga, A. Blasco, and J. Camacho. 1989. Mixed model methodology for the estimation of genetic response to selection in litter size of rabbits. Livest. Prod. Sci. 21:67-75.

Farrell, B. P., R. H. Foote, M. E. Simkin, E. D. Clegg, and R. J. Wall. 1993. Relationship of semen quality, number of sperm inseminated, and fertility in rabbits. J. Androl. 14:464-471.

Garcia-Tomás, M., J. Sanchez, O. Rafel, J. Ramon, and M. Piles. 2006. Variability, repeatability and phenotypic relationships of several characteristics of production and semen quality in rabbit. Anim. Reprod. Sci. 93:88-100.

Geweke, J. 1992. Evaluating the accuracy of sampling-based approaches to the calculation of posterior moments. Oxford Univ. Press, UK.

Geyer, C. J. 1992. Practical Markov Chain Monte Carlo. Stat. Sci. 7:473-511.

Gómez, E.A., O. Rafel, J. Ramon. 2002. The Caldes strain (Spain). Options Méditerranéennes. Série B, Études et Recherches 38:193-198.

Gómez, E. A., O. Rafel, J. Ramon, and M. Baselga. 1996. A genetic study of a line selected on litter size at weaning. Proc. 6th World Rabbit Congr., Toulouse, France 2:289-292.

Hamann, H., R. Steinheuer, and O. Distl. 2004. Estimation of genetic parameters for litter size as a sow and boar trait in German herdbook Landrace and Pietrain swine. Livest. Prod. Sci. 85:201-207.

Kolmodin, R. 2003. Reaction Norms for the study of genotype by environment interaction in animal breeding. PhD Diss. Swedish Univ. of Agricultural Sciences, Uppsala, Sweden.

Koops, W. J., M. Grossman, and J. H. G. den Daas. 1995. A model for reproductive efficiency in dairy bulls. J. Dairy Sci. 78:921-928. 
López, F. J., J. M. R. Alvariño, J. A. Del Arco, F. Delgado, and J. L. Ramiro. 1996. Effect of cooling temperature on 24 hours stored semen for artificial insemination. Proc. 6th World Rabbit Congr., Toulouse, France 2:79-81.

Mathur, P. K. 2002. Methods for estimation and use of genotype-environment interaction. Proc. 7th World Congr. Genet. Appl. Livest. Prod., Montpellier, France XVI: 32:325-332.

Maxwell, W. M. C., and L. A. Johnson. 1999. Physiology of spermatozoa at high dilution rates: The influence of seminal plasma. Theriogenology 52:1353-1362.

Nadir, S., R. G. Saacke, J. Bame, J. Mullins, and S. Degelos. 1993. Effect of freezing semen and dosage of sperm on number of accessory sperm, fertility, and embryo quality in artificially inseminated cattle. J. Anim. Sci. 71:199-204.

Piles, M., M. L. Garcia, O. Rafel, J. Ramon, and M. Baselga. 2006. Genetics of litter size in three maternal lines of rabbits: Repeatability versus multiple-trait models. J. Anim. Sci. 84:23092315.

Piles, M., O. Rafel, J. Ramon, and L. Varona. 2005. Genetic parameters of fertility in two lines of rabbits with different reproductive potential. J. Anim. Sci. 83:340-343.

Raftery, A. E., and S. Lewis. 1992. How many iterations in the Gibbs Sampler? Bayesian Statistics 4. Oxford Univ. Press, NY.

Roca, J., S. Martinez, J. M. Vazquez, X. Lucas, I. Parrilla, and E. A. Martinez. 2000. Viability and fertility of rabbit spermatozoa diluted in tris-buffer extenders and stored at 15 degrees C. Anim. Reprod. Sci. 64:103-112.

Rosato, M. P., P. G. Rebollar, and N. Iaffaldano. 2006. Comparación de diluyentes en las características cualitativas del semen de conejo durante su conservación. Symposium de Cunicultura, Lorca, Spain XXXI:9-13.

Saacke, R. G., J. C. Dalton, S. Nadir, R. L. Nebel, and J. H. Bame. 2000. Relationship of seminal traits and insemination time to fertilization rate and embryo quality. Anim. Reprod. Sci. 60:663-677.

See, M. T., J. W. Mabry, and J. K. Bertrand. 1993. Restricted maximum likelihood estimation of variance components from field data for number of pigs born alive. J. Anim. Sci. 71:2905-2909.

Sorensen, D., and D. Gianola. 2002. Likelihood, bayesian, and MCMC methods in quantitative genetics. Springer Science + Business Media, LLC, 233 Spring Street, NY.

Sorensen, D. A., S. Andersen, D. Gianola, and I. Korsgaard. 1995. Bayesian-Inference in Threshold Models using Gibbs Sampling. Genet. Sel. Evol. 27:229-249.

Van der Lende, T., M. H. A. Willemsen, J. A. M. van Arendonk, and E. B. P. G. van Haandel. 1999. Genetic analysis of the service sire effect on litter size in swine. Livest. Prod. Sci. 58:91-94.

Varona, L., and J. L. Noguera. 2001. Variance components of fertility in spanish landrace pigs. Livest. Prod. Sci. 67:217-221.

Vishwanath, R., and P. Shannon. 1997. Do sperm cells age? A review of the physiological changes in sperm during storage at ambient temperature. Reprod. Fertil. Dev. 9(3):321-332.

Wright, S. 1934. An analysis of variability in number of digits in an inbred strain of Guinea pigs. Genetics 19:506-536.

Xu, X., S. Pommier, T. Arbov, B. Hutchings, W. Sotto, and G. R. Foxcroft. 1998. In vitro maturation and fertilization techniques for assessment of semen quality and boar fertility. J. Anim. Sci. 76:3079-3089 


\section{Chapter five. Using the product}

\section{threshold model for estimating}

\section{separately the effect of temperature on}

\section{male and female fertility}

L. Tusell, I. David, L. Bodin, A. Legarra, O. Rafel, M. López-Bejar and M. Piles

J. Anim. Sci. July 15, 2011 jas.2011-3924; published ahead of print July 15,

2011, doi:10.2527/jas.2011-3924

Accepted for publication in Journal of Animal Science

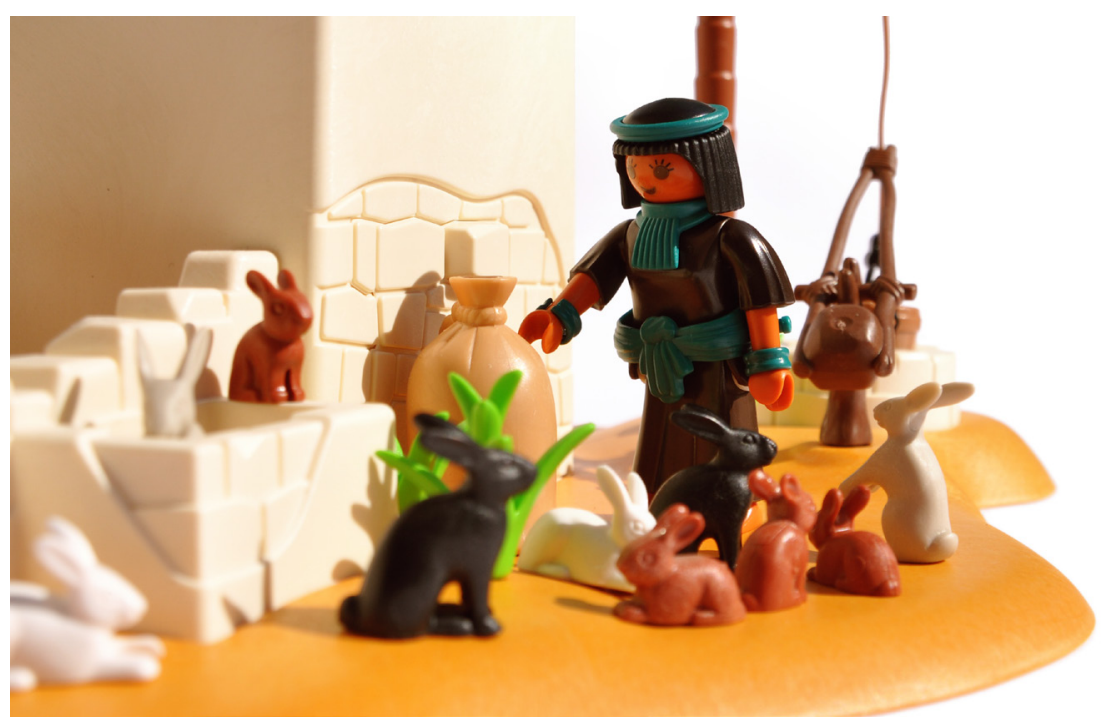

This research was supported by the Instituto Nacional de Investigación y Tecnología Agraria y Alimentatia (INIA, madrid, Spain) project RTA2005-00088-C02. Part of it was carried out during a visit of the first author to INRA (Castanet-Tolosan, France), Toulouse. Llibertat Tusell Palomero received a fellowship from the INIA. The authors are grateful to the staff of Unitat de Cunicultura, IRTA (Caldes de Montbui, Barcelona, Spain) for their valuable cooperation. 


\section{Abstract}

Animals under environmental thermal stress conditions have reduced fertility due to impairment of some mechanisms involved in their reproductive performance that are different in males and females. As a consequence, the most sensitive periods of time and the magnitude of effect of temperature on fertility can differ between sexes. The objective of this study was to estimate separately the effect of temperature in different periods around the insemination time on male and on female fertility by using the product threshold model. This model assumes that an observed reproduction outcome is the result of the product of two unobserved variables corresponding to the unobserved fertilities of the two individuals involved in the mating. A total of 7,625 AI records from rabbits belonging to a line selected for growth rate and indoor daily temperature records were used. The average maximum daily temperature and the proportion of days in which the maximum temperature was above $25^{\circ} \mathrm{C}$ were used as temperature descriptors. These descriptors were calculated for several periods around the AI day. In the case of males, four periods of time covered different stages of the spermatogenesis, the transit through the epididymus of the sperm and the AI day. For females, 5 periods of time covered the phases of preovulatory follicular maturation including AI day and ovulation, fertilization and peri-implantational stage of the embryos, embryonic and early fetal periods of gestation, and finally, late gestation until birth. The effect of the different temperature descriptors was estimated in the corresponding male and female liabilities in a set of threshold product models. The temperature of the AI day seems to be the most relevant temperature descriptor affecting male fertility, since high temperature records in the AI day caused a decrease in male fertility $(-6 \%$ in male fertility rate with respect to thermoneutrality). Departures from the thermal zone in temperature descriptors covering several periods before AI until early gestation had a negative effect on female fertility, being especially sensitive the peri-implantational period of the embryos (from -5 to $-6 \%$ in female fertility rate with respect to thermoneutrality). The latest period of gestation was unaffected by the temperature. Overall, magnitude and persistency of the temperatures reached in the conditions of this study do not seem to be high enough to have a large effect on male and female rabbit fertility.

Keywords: heat stress, fertility, product threshold model, rabbit, temperature. 


\section{Introduction}

Animals exposed to climatic thermal stress have problems in the maintenance of their regular productive and reproductive performances. Males and females are affected in a different way by thermal stress (see review by Marai et al., 2002): rabbit does exposed to heat stress reach the age at puberty later and have reduced conception and embryonic developmental rates whereas, in the case of bucks, testosterone concentration, spermatogenesis, libido, and some seminal traits are also factors affected by heat stress. Success of AI involves different male and female physiological events which could be specifically affected by temperature conditions. Therefore, the most sensitive period around the insemination time and the effect of the intensity and/or the duration of the exposure to this environmental factor could also be sex dependent. The knowledge of the existence of these sexual differences concerning sensitivity to environmental temperature could lead to implement different strategies of farm and breeding management and even of selection if the goal is to obtain tolerant animals to thermal stress.

The product threshold model (David et al., 2009) is an interesting model to separately establish the effect of temperature conditions on male and female fertility. This model assumes that an observed reproduction outcome is the result of the product of two unobserved variables corresponding to the fertility of the two individuals involved in the mating. This approach, compared with the classical analysis using the additive threshold model, has the advantage to provide specific estimates of the effects affecting each one of the members involved in the process.

The objective of the present study was to determine the effect of temperature conditions at different periods around the insemination time on male and on female rabbit fertility and to find the temperature descriptor which gives a better description of the effect of temperature on these traits.

\section{Materials and methods}

The research protocol was approved by the animal care and use committee of the Institut de Recerca i Tecnologia Agroalimentàries (IRTA).

\section{Fertility Data}

Animals used in this study came from the Caldes line (Gómez et al., 2002) which is selected for growth rate during the fattening period. This line is bred and reared on an experimental farm belonging to IRTA in Caldes de Montbui (Barcelona, Spain). After weaning at $32 \mathrm{~d}$, animals are 
housed in cages of eight individuals with a photoperiod of $16 \mathrm{~h}$ light/d. They are fed ad libitum with a commercial diet (15.5\% CP, 2.3\% fat, 17.2\% fiber) until $60 \mathrm{~d}$. After this period, selected replacement males are allocated in another building of the farm whereas replacement females remain in the same building. Since then, males and females are individually housed and fed restricted to $180 \mathrm{~g} / \mathrm{d}$ of another commercial diet (16\% crude protein, $4.3 \%$ fat, $17 \%$ fiber). Fresh water is always available.

Young males start the training to ejaculate extraction with artificial vagina at 4.5 mo of age. One ejaculate per male is collected weekly during the following 2 wk. At 5 mo of age males started their reproductive life and 2 ejaculates per male are collected weekly, with an interval of $30 \mathrm{~min}$ between collections. To prepare the AI doses, gel plugs are removed and, by visual detection, only the ejaculates with presence of urine or calcium carbonate deposits are discarded. Ejaculates are diluted 1:4 (vol/vol) in a commercial extender (Galap, IMV Technologies, Saint Ouen sur Iton, France) and the AI doses of $0.5 \mathrm{~mL}$ are applied within no more than $1 \mathrm{~h}$ after collection.

Females follow a semi-intensive reproductive rhythm: first AI at approximately 4.5 mo of age, with subsequent $42 \mathrm{~d}$ reproductive cycles. At $48 \mathrm{~h}$ before AI, all females are treated with $15 \mathrm{IU}$ eCG (subcutaneously; Foligon, Intervet International B.V., Booxmeer, Holland). Ovulation is induced immediately after AI with $0.02 \mathrm{mg}$ of Gonadorelin (intramuscularly; Fertagyl, Intervet internacional B.V. Booxmeer, Holland). Does are placed in maternal cages and fed ad libitum 2 wk before parity.

Diagnosis of pregnancy is made by abdominal palpation $14 \mathrm{~d}$ after the AI; but the fertility score is finally assigned at birth: 1 if the female give birth and 0 otherwise.

A total of 7,625 fertility records after AI were obtained from June 2006 to October 2009.

\section{Temperature Records}

Daily temperature was automatically recorded every $30 \mathrm{~min}$ in a data logger (Tinytag, Gemini Data Loggers, Chichester, United Kingdom) in the male and female buildings during the same period of collection of fertility data. Both buildings have isolated roof, walls and cooling ventilation systems to avoid animal exposure to extreme temperatures. However, because of the not total isolation of the buildings, the indoor temperature records partially reflected the seasonality of the outdoor temperature.

Table 5.1 shows summary statistics of the AI data and the daily maximum temperature records of the male and female buildings. 
Table 5.1. Distribution of AI data and maximum temperature in the AI day

\begin{tabular}{|c|c|}
\hline Fertility data & \\
\hline Number of records & 7,625 \\
\hline Number of females & 2,960 \\
\hline Number of males & 331 \\
\hline Mean (SD) number of records per female & $2.58(2.13)$ \\
\hline Mean (SD) number of records per male & $23.03(15.99)$ \\
\hline Observed Fertility (\%) & 71 \\
\hline \multicolumn{2}{|l|}{ Maximum temperature records, Co } \\
\hline $\begin{array}{l}\text { Female building } \\
23.11(3.52)\end{array}$ & $\begin{array}{l}\text { Male building } \\
22.63(3.56)\end{array}$ \\
\hline Minimum, maximum & $10.4,39.9$ \\
\hline
\end{tabular}

Three types of temperature descriptors were used: 1) the maximum temperature on the day of $\mathrm{AI}\left(\operatorname{Tmax},{ }^{\circ} \mathrm{C}\right), 2$ ) the average of maximum daily temperatures during a time period (avgTmax, ${ }^{\circ} \mathrm{C}$ ), and 3) over the same period, the proportion of days with maximum temperature higher than $25^{\circ} \mathrm{C}$ (DI, percentage). This last type of descriptor quotes for the duration and intensity of the hot conditions.

In order to accommodate possible non-linear effect of these variables on AI success, the continuous values of the Tmax and avgTmax descriptors were classified into to 5 categories: $\leq$ $18^{\circ} \mathrm{C}, 19$ to $22^{\circ} \mathrm{C}, 23$ to $24^{\circ} \mathrm{C}, 25$ to $26^{\circ} \mathrm{C}$, and $\geq 27^{\circ} \mathrm{C}$. The DI descriptors were classified into to 5 categories as well: 0 to $20 \%,>20$ to $40 \%$, > 40 to $60 \%$, > 60 to $80 \%$, and $>80$ to $100 \%$.

The temperature descriptors were calculated for several periods covering the main physiological events which lead from gametes maturation in both sexes to gestation and birth after AI. Figure 5.1 shows these different events and the corresponding temperature descriptors. 


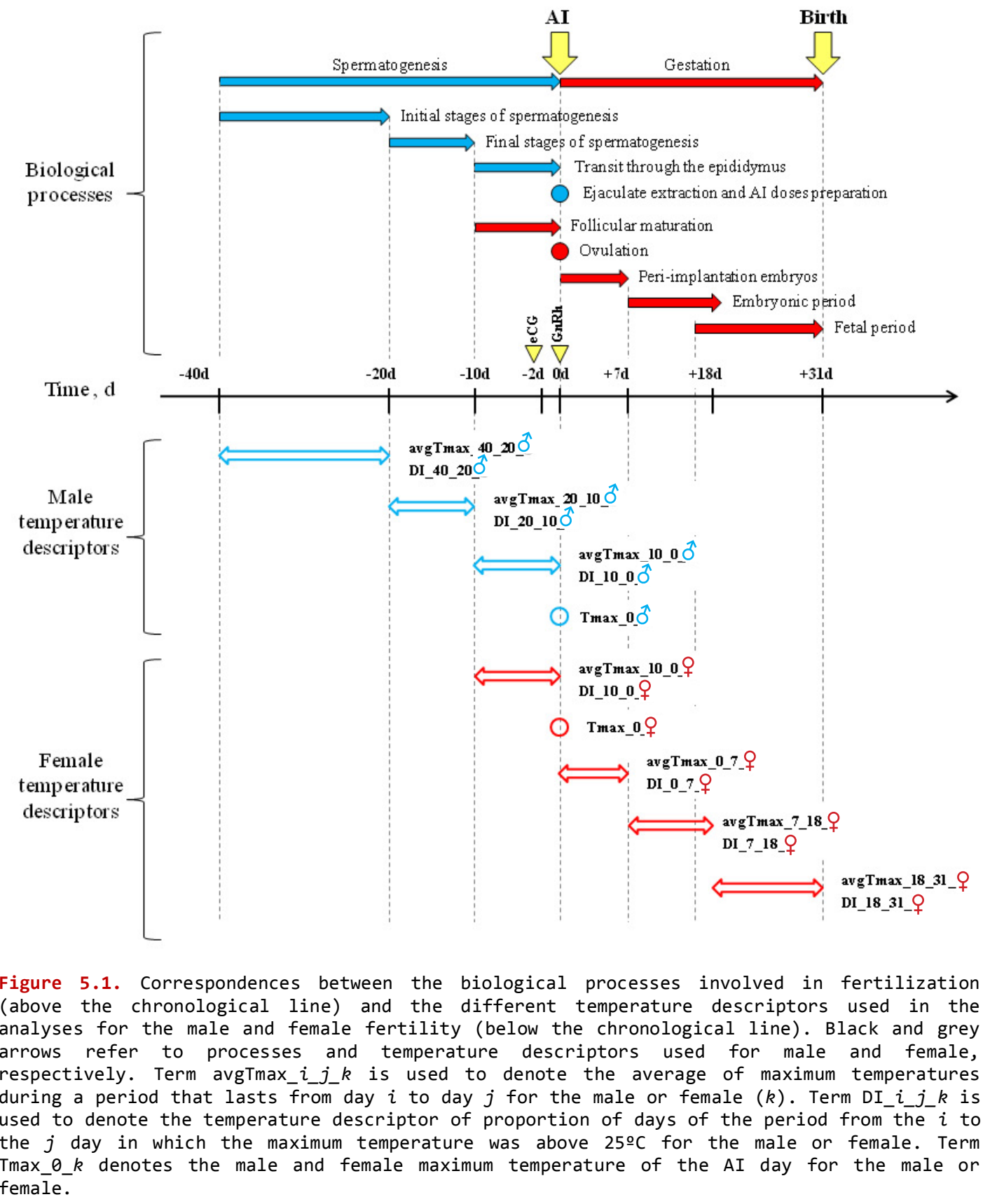

\section{Temperature Descriptors used for Male $\left(\beta_{0^{*}}\right)$}

The temperature descriptors used for the male covered the whole spermatogenesis period which lasts approximately 38 to $41 \mathrm{~d}$ in the adult buck (Alvariño, 2000). Subsequently, four temperature descriptors from the day of AI to $40 \mathrm{~d}$ backwards according to the main phases established in rabbits by Swierstra and Foote (1965) were used (see Figure 5.1): 
1) The avgTmax_40_20_ô and DI_40_20_@ were calculated in the period from d 40 to $\mathrm{d} 21$ prior to AI, which comprises the initial stages of spermatogenesis where proliferation and maintenance of spermatogonia by mitotic divisions and the subsequent meiosis until the formation of spermatids is undergone.

2) The avgTmaxT_20_10_ô and DI_20_10_ô were calculated in the period ranging from day 20 to day 11 prior to AI day which covers from spermatid stage until the end of spermatogenesis.

3) The avgTmax_10_0_ô and DI_10_0_ô were calculated in the period from d 10 until the day previous to $\mathrm{AI}$ and covers the maturation processes occurred during the transit and the storage of the sperm through the epididymus.

4) The Tmax_0_o is the maximum temperature in the AI day, which encompasses the AI doses preparation, insemination and changes related to the fertilization process.

\section{Temperature Descriptors used for Female $\left(\beta_{q}\right)$}

The following temperature descriptors were used for the female (see Figure 5.1):

1) The avgTmax_10_0_ㅇ and DI_10_0_P were calculated in the period from d 10 before AI until the day previous to AI. That approximately covers the period of lifespan of the mature follicles (Hill and White, 1933) which can be present in the ovarian surface until the period previous to ovulation. Under commercial conditions of AI, does are superovulated by hormonal treatment $48 \mathrm{~h}$ before AI (Alvariño, 1993), which improves receptivity and increases and synchronizes follicle growth as well as ovulation rate (Maertens et al., 1995).

2) The Tmax_0_+ is the maximum temperature in the AI day. That encompasses the ovulation event, the migration of the ova to the fertilization site and the fertilization process (Harper, 1963).

The gestation length in the female rabbit lasts 30 to $32 \mathrm{~d}$ (Prud'hon, 1970).

3) The avgTmax_0_7_+ and DI_0_7_o were calculated in the period from the day after AI until d 7 after AI to cover the period of peri-implantation embryonic development (Nomina Embryologica Veterinaria 1994; Lee and De Mayo, 2004).

4) The avgTmax_7_18_o and DI_7_18_우 were calculated in the period from d 8 to d 18 after AI which covers the embryo and early fetal gestation (Nomina Embryologica Veterinaria 1994). 
5) The avgTmax_18_31_o and DI_18_31_- were calculated in the period from d 19 to d 31 after AI covering the late gestation until birth.

\section{Model and Statistical Analysis}

The product threshold model assumes that conception after AI (the observed phenotype) occurs when both male and female are fertile. Thus, the probability of AI success is the product of the probability of two binary unobserved phenotypes corresponding to the male and female fertilities (David et al., 2009). These hidden phenotypes can be modeled using two unobserved, underlying continuous variables (liabilities) having each one a fixed threshold that divides its continuous scale into 2 response categories: success and failure (Wright, 1934). In matrix notation, the product threshold model used in this study can be expressed as follows:

$$
\begin{aligned}
& \operatorname{Pr}\left(\mathbf{y}=1 \mid \boldsymbol{\beta}_{m}, \boldsymbol{\beta}_{f}, \boldsymbol{\beta}_{p s}, \mathbf{p}_{m}, \mathbf{p}_{m d}, \mathbf{p}_{f}\right)=\Phi\left(\mathbf{X}_{m} \boldsymbol{\beta}_{m}+\mathbf{Z}_{1, m} \mathbf{p}_{m}+\mathbf{Z}_{2, m} \mathbf{p}_{m d}\right) \\
& \times \Phi\left(\mathbf{X}_{1, f} \boldsymbol{\beta}_{f}+\mathbf{X}_{2, f} \boldsymbol{\beta}_{p s}+\mathbf{Z}_{f} \mathbf{p}_{f}\right)
\end{aligned}
$$

Where $\mathbf{y}$ is the vector of the observed AI results (1: success to conception, 0 otherwise), $\Phi$ is the standard cumulative distribution function of a standard normal distribution, $\boldsymbol{\beta}_{m}$ and $\boldsymbol{\beta}_{f}$ are the vectors of temperature descriptor effects previously described for male and female respectively, and $\boldsymbol{\beta}_{p s}$ is the vector of the effect of the physiological status of the female ( 3 levels: nulliparous, multiparous in lactation, and multiparous not in lactation at AI), $\mathbf{p}_{m}$ is the vector of male effects, $\mathbf{p}_{m d}$ accounts for the interaction between male and day of AI, and $\mathbf{p}_{f}$ is the vector of female effects. Random effects $\mathbf{p}_{m}, \mathbf{p}_{m d}$ and $\mathbf{p}_{f}$ were considered uncorrelated. Terms $\mathbf{X}_{m}, \mathbf{X}_{1, f}, \mathbf{X}_{2, f}, \mathbf{Z}_{1, m} \mathbf{Z}_{2, m d}$, and $\mathbf{Z}_{f}$ are incidence matrices relating data with the systematic, and random effects included in the model.

In our study we have considered different models that only differed by the systematic effects $\boldsymbol{\beta}_{m}$ and $\boldsymbol{\beta}_{f}$. Due to the high colinearity between temperature descriptors within sex, all these models included only one temperature descriptor for each hidden phenotype. Most of the possible combinations between male and female temperature descriptors were previously analyzed in several models (data not shown), and since they provided similar estimates for the effect of the male temperature descriptor, irrespectively of the temperature descriptor used for the female, and vice versa, only the results of 11 different models are presented (Table 5.2). 
Table 5.2. Different product threshold models including several temperature descriptors in the male and the female liabilities of fertility ( $\boldsymbol{\beta}_{\text {and }} \boldsymbol{\beta}_{+}$, respectively).

\begin{tabular}{|c|c|c|}
\hline Model & $\beta_{\hat{\delta}}$ & $\beta_{q}$ \\
\hline 1 & avgTmax_40_20_ô ${ }^{1}$ & avgTmax _0_7_o ${ }^{1}$ \\
\hline 2 & DI_40_20_( ${ }^{2}$ & DI_0_7_O ${ }^{2}$ \\
\hline 3 & avgTmax_20_10_ô1 & 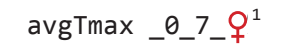 \\
\hline 4 & DI_20_10_ô ${ }^{i^{2}}$ & DI_0_7_O ${ }^{2}$ \\
\hline 5 & avgTmax_10_0_ô'1 & avgTmax_10_0_o' ${ }^{1}$ \\
\hline 6 & DI_10_0_ổ ${ }^{2}$ & DI_10_0_O ${ }^{2}$ \\
\hline 7 & 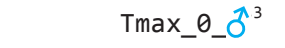 & Tmax_0_Q ${ }^{3}$ \\
\hline 8 & avgTmax_40_20_ổ & avgTmax _7_18_o ${ }^{1}$ \\
\hline 9 & DI_40_20_- ${ }^{2}$ & DI_7_18_o ${ }^{2}$ \\
\hline 10 & avgTmax_20_10_ơ & avgTmax_18_31_o ${ }^{1}$ \\
\hline 11 & DI_20_10_ti ${ }^{2}$ & DI_18_31_ P $^{2}$ \\
\hline \multicolumn{3}{|c|}{$\begin{array}{l}\text { Term avgTmax_i_j_k is used to denote the average } \\
\text { of maximum temperatures during a period that } \\
\text { lasts from day } i \text { to day } j \text { for the male or female } \\
(k) \text {. } \\
2 \text { Term DI_ } i \_j \_ \text {is used to denote the temperature } \\
\text { descriptor of proportion of days of the period } \\
\text { from the } i \text { to the } j \text { day in which the maximum } \\
\text { temperature was above } 25 \text { oc for the male or female } \\
(k) \text {. } \\
{ }^{3} \text { Term Tmax_ } \theta-k \text { denotes the male and female maximum } \\
\text { temperature of the AI day for the male or female } \\
(k) \text {. }\end{array}$} \\
\hline
\end{tabular}

The season effect was not considered in the analysis, since it is highly confounded with the environmental temperature. The age of the male was also not included because of the non relevant effect founded in preliminary analyses. The age of the female is partially encompassed with the physiological status of the female, included in the female side of the model.

A Bayesian framework was adopted for inference. The assigned prior distributions for the parameters of the models were:

$p(\boldsymbol{\beta}) \sim k, \quad p\left(\mathbf{p}_{i} \mid \sigma_{i}^{2}\right) \sim N\left(\mathbf{0}, \mathbf{I} \otimes \sigma_{i}^{2}\right)$ for $i=m, f, m d$. Term $k$ is a constant, $\sigma_{i}^{2}$ is the variance for male, female, and interaction between male and day of AI random effects respectively. Flat bounded priors were used for variances. Thresholds and residual variances were fixed to 0 and 1, respectively. For details, see David et al. (2009). The marginal posterior distributions of the parameters of interest were derived from the joint posterior density of all the unknown parameters. The Gibbs sampler algorithm was used to estimate the marginal posterior distributions of the systematic effects and the variance components. Single chains of 200,000 iterations were run for all the analyses. The first 20,000 iterations of each chain were discarded, and samples of the parameters of interest were saved every 100 rounds. The number of discarded samples was, in all cases, much larger than the required burn-in determined by using Raftery and Lewis (1992) and Geweke (1992) procedures. The sampling variance of the chains was obtained by computing Monte Carlo SE (Geyer, 1992). Summary 
statistics from the marginal posterior distributions were calculated directly from the samples saved.

Male and female unobserved phenotypic variances were obtained as the sum of all corresponding variance components of each sex. Ratios of variance were obtained dividing each variance component by the corresponding unobserved phenotypic variance.

\section{Criteria used to Test the Relevance of the Effect of Temperature Descriptors on Male and Female Fertilities}

Rabbit comfort temperature is considered to be around $21^{\circ} \mathrm{C}$ (Marai et al., 2002). Consequently, the second levels of Tmax and avgTmax descriptors would correspond to zone of thermal neutrality (ranging from 19 to $23^{\circ} \mathrm{C}$ ) at which other levels were compared. For the DI descriptors, in absence of references in the literature concerning the effect of a persistently high temperature over a period on the fertility, we choose arbitrarily the second level as the reference ( 20 to $40 \%$ of days in the period with maximum temperature higher than $25^{\circ} \mathrm{C}$ ). Estimates of the other levels of the temperature descriptors were obtained as contrasts to those second levels which were set to 0 . Probability of a positive/negative value of the contrast was considered. The highest posterior density intervals at 95\% (HPD ${ }_{95 \%}$ ) of the contrast were also computed.

\section{Results and discussion}

Table 5.3 shows correlations among the different temperature descriptors used in this study. As expected, the largest correlations were encountered among those temperature descriptors that were measured in the same period of time and also among those ones that were measured closer in time. Moreover, it is important to note that the temperature descriptors for the male were moderate to highly correlated with those for the female. This means that in an additive model it would not be possible to include both factors to analyze the effects of the temperature on the global fertility since there would be a colinearity effect on these estimates. 


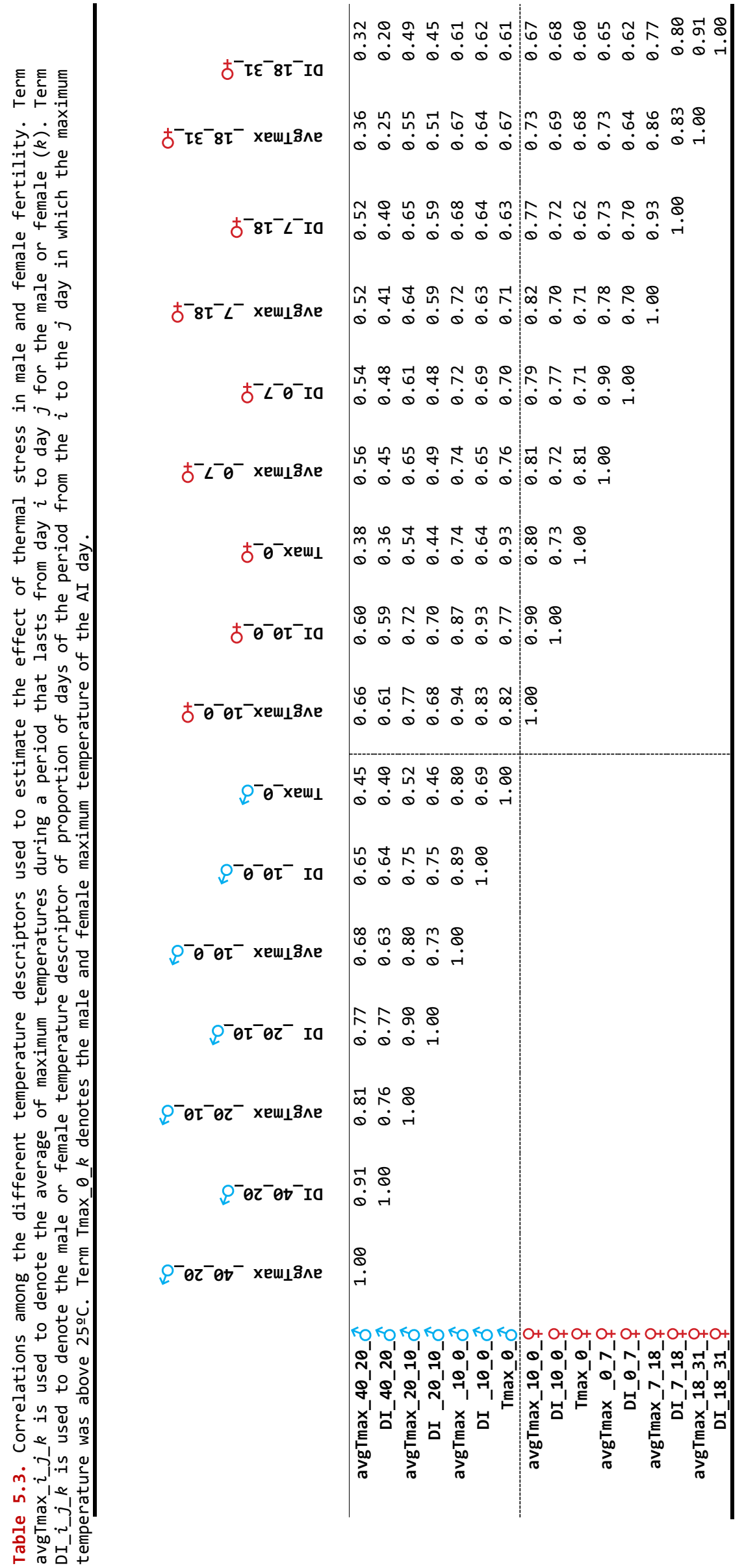


Figure 5.2 (panel A) shows the monthly percentage of AI success and the average maximum temperature per month in the male and female buildings recorded during the experimental period of this study. A regular decrease of the AI success was observed from February to July when the temperature increased. The greatest observed AI success was reached during the coldest period of the year and the lowest one occurred during the summer time. The detrimental effects of heat stress on conception rate have been described by several authors, especially in countries with hot climate conditions (Marai et al., 2006; Yassein et al., 2008). In rabbit, the number of functional sweat glands is scarce and its fur does not allow a great perspiration. The increase of respiration rate, changes in body position and heat dissipation via ear lobes appear as the main mechanisms to mitigate heat in this species (Harkness, 1988). When those mechanisms are not enough efficient to dissipate the amount of heat above the zone of thermal neutrality, deterioration of growth, resistance to diseases and impairment in reproductive performance appears with the subsequent economical looses for the breeders (reviewed by Marai et al., 2002). 
PANEL A
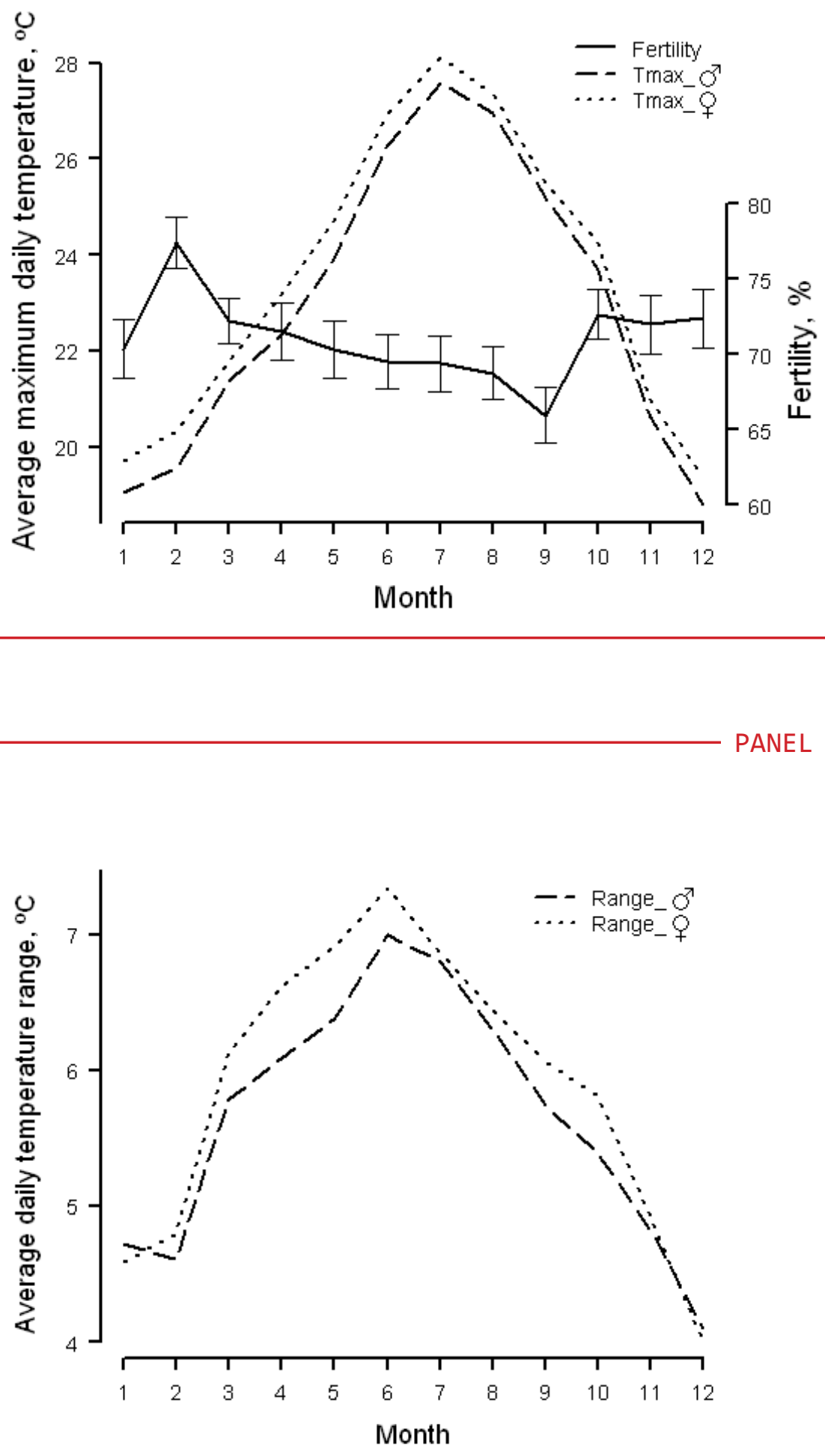

Figure 5.2. Panel A: Average maximum daily temperature recorded per month in the male and female building (Tmax_o and Tmax_ô, respectively) and average percentage of fertility success per month (SE in bars). Panel B: Average daily temperature range recorded per month in the male and female building (Range_ $\hat{O}$ and Range_o, respectively). 
The posterior mean (PM) of the probabilities of success (David et al., 2009) were approximately 0.87 for the male and approximately 0.83 for the female fertility in all models. Equal Monte Carlo standard errors were obtained for both estimates in all the models (0.002). With a similar data set of the same line of rabbits and using the same product threshold model, David et al. (2010) found very close values for the probabilities of fertility success.

Estimates of the posterior mean of total variance of each underlying variable, ratios of variance attributable to male and the interaction between male and day of AI in the male liability as well as the ratio of variance due to the female effect in the female liability were similar among the models. Surprisingly, in model 4 (Table 5.2) the posterior standard deviation of the estimates of these figures were larger than the corresponding ones obtained in the other models.

Figures 5.3 and 5.4 as well as Figures 5.5 and 5.6 show estimates (PM) and their corresponding confidence intervals $\left(\mathrm{HPD}_{95 \%}\right.$ ) of the effect of the temperature descriptors in male and female unobserved fertility in a 0 to 1 scale, respectively. The effect of some temperature descriptors were estimated in more than one model (obtaining the same estimates). For simplicity, only the estimates obtained in models 1 to 7 and models 1,3 to 11 for the male and female temperature descriptors, respectively, are presented (Table 5.2).

\section{Effect of Temperature Descriptors on Male Fertility}

High maximum daily temperatures on the AI day represented a loss of $6 \%$ in male fertility rate with respect to thermoneutrality (Tmax_0_ô, Figure 5.3). This result indicates the susceptibility of the sperm to a high temperature during all the handling processes since the preparation of the AI doses until the time of insemination. Because of doses of 1 male in a specific day have been exposed to the same environmental temperature, it is possible that the random effect resulting from the interaction between male and day of AI could be removing part of the effect of Tmax_0_ô. However, we preferred to include this random effect in the models because it takes into account all possible environmental factors that could have had an effect on all the AI doses prepared from one male in a specific AI day, whereas the effect of the temperature of the AI day is common to all the doses of all the males that have been prepared in a specific day. Other results obtained in another rabbit fertility study by Tusell et al. (2010a) indicated that the male random effect with the greatest variance was the interaction between male and day of AI. In a similar way, this effect partly encompassed the high sensitivity of the semen to the effect of environmental factors during the processes of dose preparation and application. However, a proportion of the variation obtained for this effect in the 2 models cannot be properly compared. The additive threshold model considers the existence of a unique linear variable underlying the categorical trait and the proportion of variance of a certain male or female effect is referred to phenotypic variation of this common underlying 
variable. However, under the product threshold model, it is assumed that two underlying variables exist: the liability of male fertility (non-observable male phenotype) and the liability of female fertility (non-observable female phenotype). In that case, the proportion of variance of a certain effect is referred to the phenotypic variation of the corresponding male or female liability.
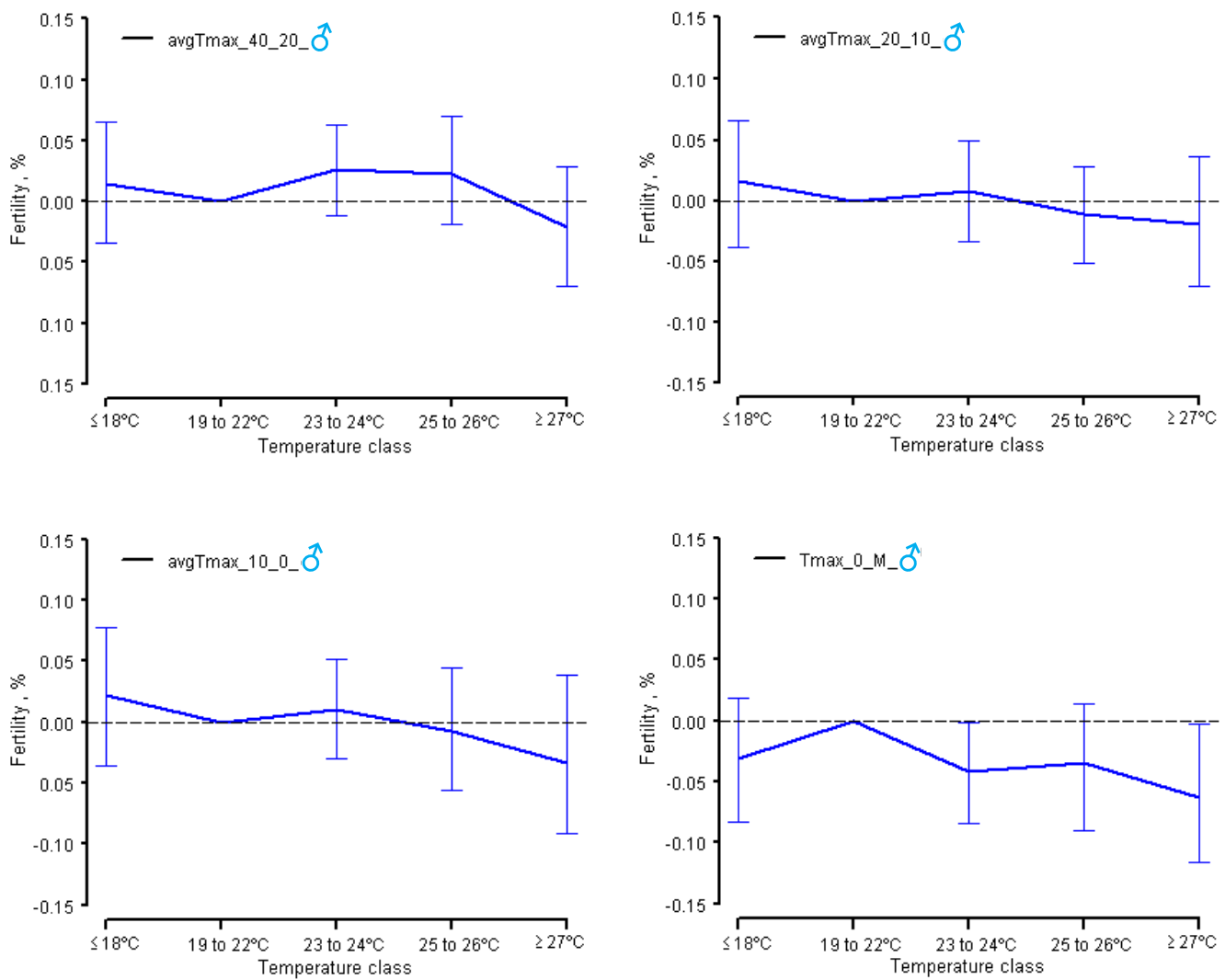

Figure 5.3. Posterior mean and highest posterior density interval at $95 \%$ of the effects on male fertility rate of the average maximum daily temperatures in the periods from $40 \mathrm{~d}$ to $21 \mathrm{~d}$ prior to $\mathrm{AI}$, from $20 \mathrm{~d}$ to $11 \mathrm{~d}$ prior to $\mathrm{AI}$ and from $10 \mathrm{~d}$ to $1 \mathrm{~d}$ prior to AI (avgTmax_40_20_ô, avgTmax_20_10_o and avgTmax_10_0_ô, respectively) and effect on male fertility rate of the maximum temperature the day of AI (Tmax 0 ). Estimates of each figure were obtained in the models $1,3,5$, and 7, respectively (detailed in Table 5.3). 
In this work, none of the temperature descriptors covering spermatogenesis had a clear influence on male fertility (period from 40 to $10 \mathrm{~d}$ prior to AI, Figures 5.3 and 5.4).
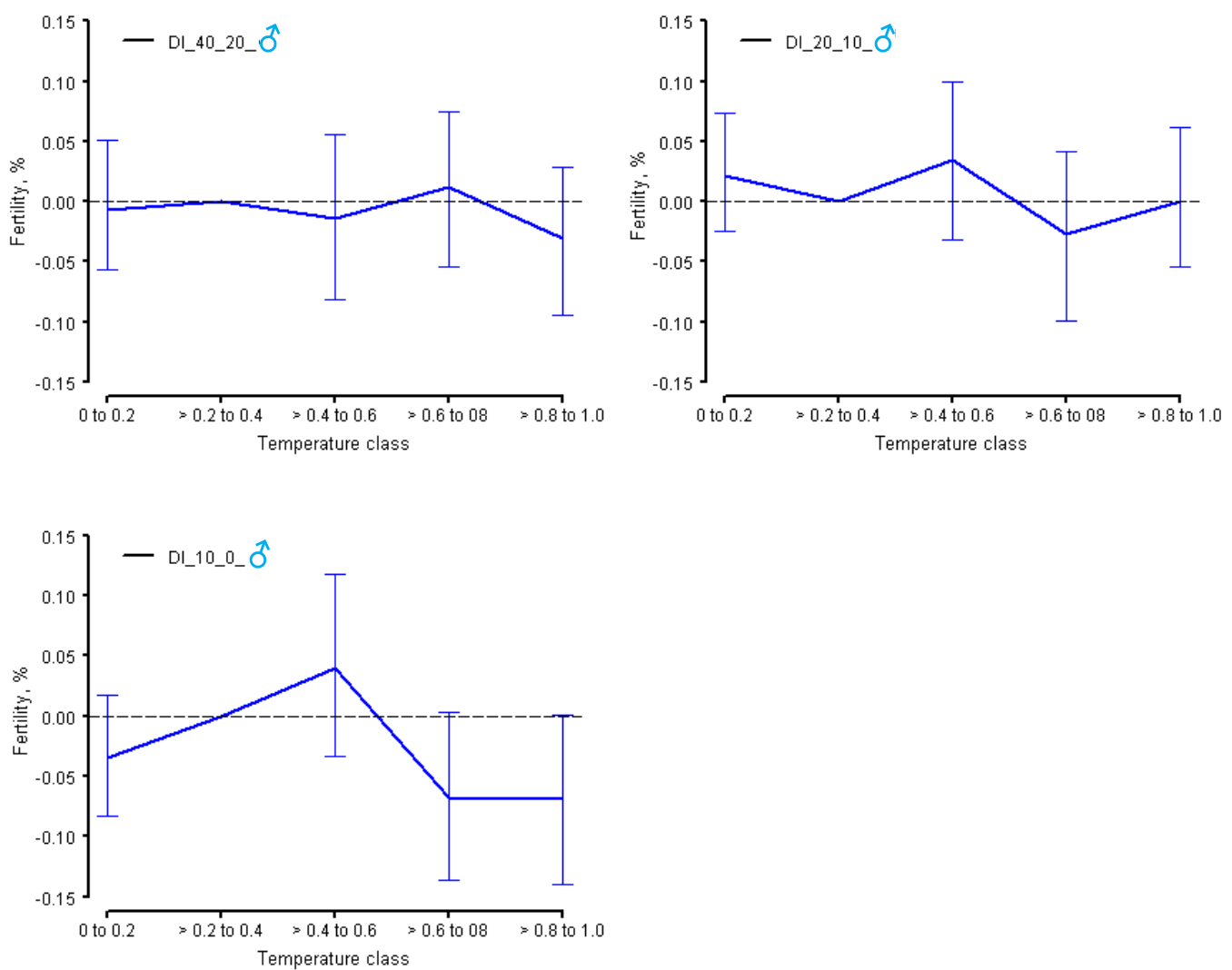

Figure 5.4. Posterior mean and highest posterior density interval at $95 \%$ of the effects on male fertility rate of the percentage of days with maximum temperature higher than $25 \circ \mathrm{C}$ in the periods from $40 \mathrm{~d}$ to $21 \mathrm{~d}$ prior to $\mathrm{AI}$, from $20 \mathrm{~d}$ to $11 \mathrm{~d}$ prior to AI and from $10 \mathrm{~d}$ to 1 $d$ prior to AI (DI 40 20 $\hat{O}$, DI $2010 \hat{0}$ and DI $100 \hat{0}$, respectively). Estimates of each figure were obtained in the models $\overline{2}, 4$, and 6 , respectively (detailed in Table 5.3).

Low and high values of maximum temperatures covering the epididymus transit stage did also not affect male fertility (avgTmax_10_0_ô; Figure 5.3). However, large percentages of days with maximum temperature above $25^{\circ} \mathrm{C}$ during the epididymal transit of the sperm (DI_10_0_O , Figure 5.4) produced a relevant decrease on male fertility (-7\% in the contrasts with the 2 highest levels, with a probability of a negative value of 97\%). Some seminal quality traits related with male fertility (Gadea, 2005; Lavara et al., 2005; Garcia-Tomás et al., 2006) such as sperm concentration, sperm abnormalities, and acrosome integrity were analyzed by Roca et al. (2005). These authors found a negative effect of the temperature-humidity index (THI) on semen quality and suggested that spermatogenesis but not the epididymal transit was affected, according with the time elapsed between the THI stress and the occurrence of an impaired semen quality, under commercial conditions. However their results should be taken 
with caution because season, light treatment and THI were included as different effects in the same model, leading presumably to confounded effects. On the other hand, Finzi et al. (1995) compared the characteristics of the spermatozoa from ejaculates obtained in consecutive weeks in males moved from thermoneutrality to heat stress conditions in a climatic chamber. They concluded that the stage of spermatid formation in the seminiferous tubules was the critical period towards the formation of sperm abnormalities. The effect of this kind of seminal traits on fertility could not be observed if the sperm dosage is high (Saacke et al., 2000), as occurs in our study. This could lead to not observe a detrimental effect on male fertility under heat stress conditions in the period from 40 to $10 \mathrm{~d}$ before the AI. However, it has been demonstrated that, in the presence of thermal stress in both the testis and the epididymus, motile and morphologically normal sperm could be obtained, but with defective chromatin (in mice, Banks et al., 2005). In turn, altered sperm DNA has a negative effect on fertility especially during the embryonic development (Saacke et al., 2000; D'Occhio et al., 2007) which could explain the negative effect of a persistently high temperature during the epididymal transit of the sperm observed in our work if it can be demonstrated that DNA structure is more sensitive to heat stress in this stage. This kind of deficiency of the spermatozoa cannot be compensated for by increasing the sperm concentration of the AI dose.

Previous results obtained in the same line showed that cold to moderate THI indices seemed to negatively affect some quantitative and qualitative semen traits (Garcia-Tomás et al., 2008). This result is not confirmed analyzing fertility results of the same line in our study, because no relevant detrimental effects were obtained in the contrasts with the lowest levels of the temperature descriptors. To our knowledge, there is no other information in the literature concerning the effect of cold to moderate temperatures in male reproductive performance. However, it is known that endothermic mammals can better tolerate low body temperatures than high body temperatures (Hansen, 2009)

\section{Effect of Temperature Descriptors on Female Fertility}

Although some of the temperature contrasts had a HPD $95 \%$ that did include the 0 , the general tendency among the female descriptors $\operatorname{Tmax}_{-}$ㅇ and avgTmax (except for the avgTmax_18_31_o; Figure 5.5) was that departures from the thermal comfort zone had a negative effect on female fertility. Heat stress produces impairment in several physiological processes involved in female reproductive performance that lead to a decrease in conception rate (Marai et al., 2002). To our knowledge, there is no information in the literature concerning the effect of low temperatures on female fertility that could confirm our results. 

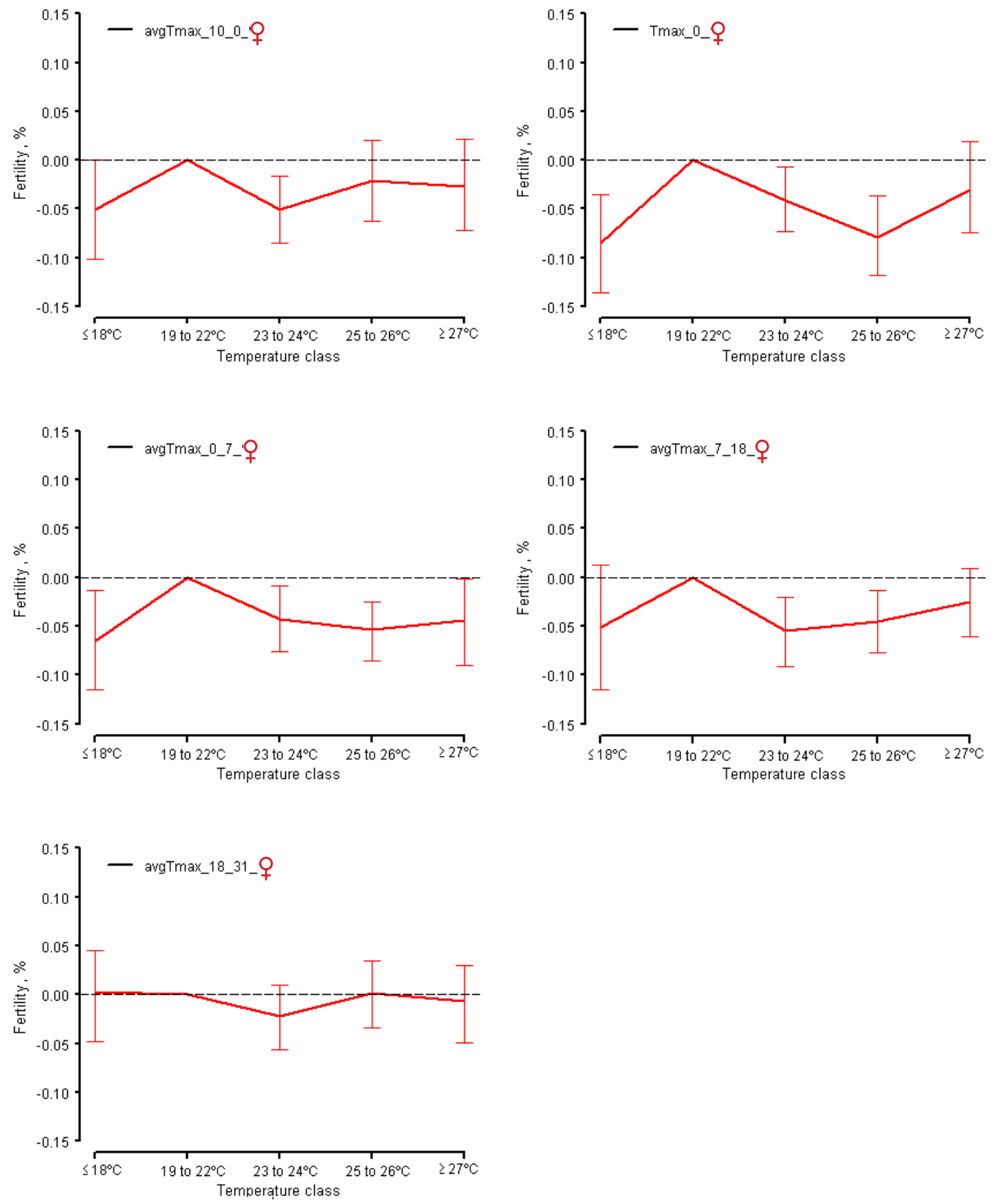

Figure 5.5. Posterior mean and highest posterior density interval at $95 \%$ of the effects on female fertility rate of the average maximum daily temperatures in the periods from $10 \mathrm{~d}$ to $1 \mathrm{~d}$ prior to $\mathrm{AI}$, from $1 \mathrm{~d}$ to $7 \mathrm{~d}$ after $\mathrm{AI}$, from $8 \mathrm{~d}$ to $18 \mathrm{~d}$ after $\mathrm{AI}$, and from $19 \mathrm{~d}$ to $31 \mathrm{~d}$ after AI (avgTmax_10_0_우, avgTmax_0_7_우, avgTmax_7_18_우 and avgTmax_18_31_우, respectively) and effect on female fertility rate of the maximum temperature the day of AI (Tmax_ $\theta_{-}+\theta_{\text {) }}$. Estimates of each figure were obtained in the models 5, 7, 1, 8, and 10, respectively (detailed in Table 5.3).

Cheng et al. (1999) observed that does exposed to high temperature before mating had a greater embryonic degeneration than those maintained in thermo neutral conditions. A reduction in the development of mature follicles and in the number of developing oocytes has been observed in rabbits during summer heat stress (Yassein et al., 2008). It has also been 
reported in cattle and goats that heat stress affects follicular dynamics and ovulation rate (Doney et al., 1973; Roth, 2008). Although a tendency is observed in our results, we cannot confirm the detrimental effect of high temperatures during the follicular maturation period and preimplantational phase of the embryos on fertility but low temperatures during the period from $10 \mathrm{~d}$ to $\mathrm{AI}$ had a negative effect on female fertility (avgTmax_10_0_o; Figure 5.5). Although estimates were imprecise, low proportion of hot days during the $10 \mathrm{~d}$ prior to $\mathrm{AI}$ as well as high proportion of hot days during the same period seemed to favorably affect female fertility (DI_10_0_o; Figure 5.6). This surprising result needs to be confirmed and could be in part related to temperature gradients that exist in the ovarian tissues of mature animals, which are generated at least in part as a consequence of endothermic reactions within Graafian follicles (Hunter et al., 2000).
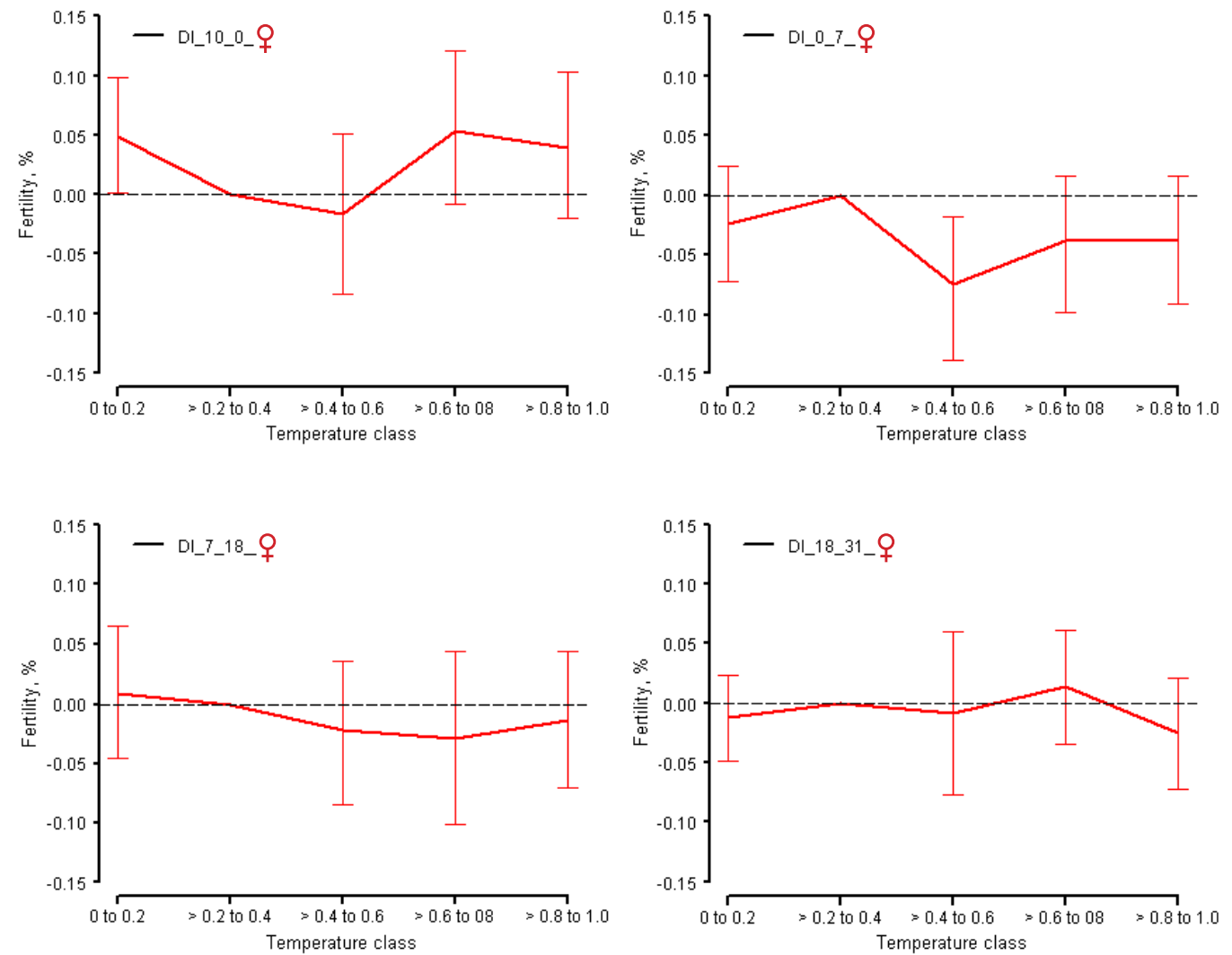

Figure 5.6. Posterior mean and highest posterior density interval at $95 \%$ of the effects on female fertility rate of the percentage of days with maximum temperature higher than 25 oc in the periods from $10 \mathrm{~d}$ to $1 \mathrm{~d}$ prior to $\mathrm{AI}$, from $1 \mathrm{~d}$ to $7 \mathrm{~d}$ after $\mathrm{AI}$, from $8 \mathrm{~d}$ to $18 \mathrm{~d}$ after AI and from $19 \mathrm{~d}$ to $31 \mathrm{~d}$ after AI (DI 10 0 0 , DI 0 7_o, DI 7 18 0 and DI 18 31 0 , respectively). Estimates of each figure were obtained in the models $\overline{6}, 2,9$, and $\overline{11}$, respectively (detailed in Table 5.3).

Low and high temperatures during the AI day negatively affect female fertility. Ovulation in does occur approximately $10 \mathrm{~h}$ after the injection of the LH at AI (Harper, 1963). Thus, it seems that processes related to the female such as ovulation and migration of the oocytes to 
the ampulla of the oviduct and fertilization could be affected by the environmental temperature of the farm in the AI day. In addition, female could be less fertile because a hyperthermic reproductive tract can also affect the fertilizing ability of the sperm and the posterior embryo survival (Howarth et al., 1965; Hansen et al., 2001). In rabbit AI, the sperm is deposited deep in the vagina and close to the cervix. Then sperm has to migrate through the cervix and the uterus, reach the isthmus of the oviduct, and remain trapped and held in a sperm reservoir until ovulation time (Harper, 1973a; Overstreet and Cooper, 1978). Once the oocytes reach the ampulla of the oviduct, hyperactivation (Ho and Suarez, 2001) and capaciation (Dziuk, 1965) of spermatozoa allow the release of sperm from the reservoir and the migration to the oocytes. Capacitated sperm is thermotactically sensitive to the gradient of temperature that exists at ovulation time between the isthmic sperm reservoir and the fertilization site. The existence of this gradient enables the migration of the sperm to the oocytes (David et al., 1972; Bahat and Eisenbach, 2006). This temperature-dependent process could be affected by thermal stress if excess heat is not correctly dissipated in the female, reducing the ability of the sperm to reach the oocytes.

It is important to note that most of the studies dealing with the impact of high ambient temperatures on preovulatory follicle maturation, fertilization and embryo development were carried out in climatic chambers or in vitro under extreme conditions of high and constant temperature. However, in commercial farm conditions, like the ones used in this study, there is a wide range of daily temperature, especially in summer (see Figure 5.2, panel B). Even in the hot season, the thermoneutrality zone is reached during the night when rabbit activity is maximum and animals eat (Prud'hon, 1975), which could enhance the heat tolerance of animals.

Departures from thermoneutrality during the pre and peri-implantation embryonic development caused a decrease in female fertility (avgTmax_0_7_o; Figure 5.5). A similar pattern was observed for DI_0_7_o (Figure 5.6) but the majority of the contrasts included the 0 in their $\mathrm{HPD}_{95 \%}$. Several authors described that this period of gestation was very sensitive to thermal stress leading to a decrease in the latter embryo development and survival (Putney et al., 1988; Ealy et al., 1993; Hansen et al., 2001). However, early embryos respond differently to thermal stress depending on their age and developmental status arriving to acquire thermotolerance in more advanced stages of development (Ealy et al., 1993; Hansen, 2009). A threshold of thermotolerance exists in rabbit preimplantation embryos exposed to high temperatures in vitro (Makarevich et al., 2007).

It seems that high and low temperatures during the embryo and early fetal gestation periods also compromise the female fertility because the probability of a negative value for the contrasts between the lowest and highest levels with the reference level was 94 and $92 \%$, respectively (avgTmax_7_18_o; Figure 5.5). However, female fertility seems to be unaffected by the proportion of days with high temperature in the same period (DI_7_18_o; Figure 5.6). 
Embryo survival in utero under heat stress conditions has been more attributable to changes in maternal physiology than to changes in the embryo itself (Hansen, 2009).

As long as the gestation advances, embryos become more resistant to the maternal exposure to heat stress (Ealy et al., 1993; Hansen et al., 2001). Accordingly, a reduction in the effect of the temperature on female fertility seemed to occur as later the temperature descriptor is measured in the gestation period. Therefore, the temperature descriptors covering gestation from $18 \mathrm{~d}$ after AI until birth had no influence on female fertility (avgTmax_18_31_우 and DI_18_31_o; Figures 5.5 and 5.6, respectively).

Finally, it is important to mention that because of the high correlation existing among the temperature descriptors it is difficult to establish which effects of the temperature are the most important. Moreover, the season of the year was not included in the model because of the confounding effect with the temperature. Therefore, temperature descriptors encompass not only the temperature effects but also all the possible season effects associated with it, such as environmental humidity and photoperiod, that could affect the AI results. However, as noted by Flowers (2008), it is likely that the most important effect observed were due mostly to temperature, especially in this study where photoperiod was artificially controlled.

\section{Effect of the Physiological Status of the Female on Female Fertility}

Fertility of nuliparous females is about 6\% (SD 0.01) less than the multiparous females in all of the models. That agrees with the lower values obtained for prolificacy traits in the first parities with respect to the second and subsequent parturitions in other rabbit lines (Baselga et al., 1992; Piles et al., 2006). In our study, no effect of lactation was encountered. That disagrees with the negative effect observed after AI of crossbred females from 2 maternal lines (Tusell et al., 2010b), as well as results obtained after natural mating of females of the same line than the one used in this work. However, no negative effect of lactation was encountered in females of a maternal line (Piles et al., 2005), which could mean that the effect of lactation on fertility is line and type of mating dependent.

The product threshold model appears as an interesting model to separately estimate the effect of some environmental factors relating male and female contributions to the fertility output (such as the different temperature descriptors analyzed in this work). However, this model assumes conditional independency between male and female fertility events. This fact, does not allow taking into account the estimation of the effect of interactions between male and female factors that exists in the mating process, as being described for several authors in the reproduction field (e.g., ovulation-associated alterations leading to changes in the pattern of sperm motility, ova stimulation of the migration of sperm from the reservoir to the fertilization site; Harper, 1973b; Overstreet and Cooper, 1978). Moreover, not only the male 
and the female but also the embryos are a third component contributing in any fertility outcome. Further work should be done in this direction in order to incorporate in the product threshold model the possibility to estimate possible interactions between the two fertility events.

In conclusion, the environmental temperature of the AI day seems to be the most relevant temperature descriptor affecting male fertility, since high temperature records in the AI day caused a decrease in male fertility. This effect could be indicative of the high sperm sensitivity to temperature changes during the processes of preparation and application of the AI doses. However, some sperm physiological processes occurring around the fertilization time could also be affected by the temperature. From the practical point of view, it seems to be advisable to handle the sperm to be used for AI in a rapid and careful manner in order to not to compromise its fertilizing ability.

Departures from the thermal zone in temperature descriptors covering several periods before AI until early gestation had a negative effect on female fertility, being especially sensitive the pre and peri-implantational period of the embryos. The latest period of gestation seemed to be unaffected by the temperature confirming the results previously described in other studies about the gain of thermotolerance reached in the latest stages of gestation.

The product threshold model allowed determining that male and female fertility are specifically affected by temperature in different periods around the insemination time. However, the magnitude and the persistency of the temperatures reached in the commercial conditions of this study do not seem to have a large effect on male and female rabbit fertility. Nevertheless, it is possible that the effect of temperature in prolific species leads to a reduction of the number of surviving embryos that could not be detected through the analysis of the pregnancy vs. non pregnancy result of AI. The analysis of prolificacy outcomes would be a different study itself and it could not take advantage of the use of the product threshold model.

\section{Literature cited}

Alvariño, J. M. R. 2000. Reproductive performance of male rabbits. Proc. 7th World Rabbit Congr. (Valencia). A:13-35.

Alvariño, R. 1993 Control de la reproducción en el conejo. Ed Mundi-Prensa. Madrid.

Bahat, A., and M. Eisenbach. 2006. Sperm thermotaxis. Mol. Cell. Endocrinol. 252:115-119.

Banks, S., S. A. King, D. S. Irvine, and P. T. K. Saunders. 2005. Impact of a mild scrotal heat stress on DNA integrity in murine spermatozoa. Reproduction 129:505-514.

Baselga, M., E. A. Gómez, P. Cifre, and J. Camacho. 1992. Genetic diversity of litter size traits between parities in rabbits. J. Appl. Rabbit Res. 15:198-205.

Cheng, H., M. P. Dooley, S. M. Hopkins, L. L. Anderson, S. Yibchok-anun, and W. H. Hsu. 1999. Development of rabbit embryos during a 96-h period of in vitro culture after superovulatory treatment under conditions of elevated ambient temperature. Anim. Reprod. Sci. 56:279-290. 
D'Occhio, M. J., K. J. Hengstberger, and S. D. Johnston. 2007. Biology of sperm chromatin structure and relationship to male fertility and embryonic survival. Anim. Reprod. Sci. 101: 117.

David, A., A. Vilensky, and H. Nathan. 1972. Temperature changes in the different parts of the rabbit's oviduct. Int. J. Gynaecol. Obstet. 10: 52-56.

David, I., L. Bodin, D. Gianola, A. Legarra, E. Manfredi, and C. Robert-Granie. 2009. Product versus additive threshold models for analysis of reproduction outcomes in animal genetics. J. Anim. Sci. 87:2510-2518.

David, I., M. J. Carabaño, L. Tusell, C. Diaz, O. Gonzalez-Recio, E. Lopez de Maturana, M. Piles, E. Ugarte, and L. Bodin. 2011. Product versus additive model for studying AI results in several livestock populations. J. Anim Sci. 89:321-328.

Doney, J. M., R. G. Gunn, and J. G. Griffiths. 1973. The effect of premating stress on the onset of oestrus and on ovulation rate in scottish blackface ewes. J. Reprod. Fertil. 35:381-384.

Dziuk, P. J. 1965. Double mating of rabbits to determine capacitation time. Reproduction. 10:389-395.

Ealy, A. D., M. Drost, and P. J. Hansen. 1993. Developmental changes in embryonic resistance to adverse effects of maternal heat stress in cows. J. Dairy Sci. 76:2899-2905.

Finzi, A., P. Morera, and G. Kuzminsky. 1995. Sperm abnormalities as possible indicators of rabbit chronic heat stress. World Rabbit Sci. 3:157-161.

Flowers, W. L. 2008. Genetic and phenotypic variation in reproductive traits of AI boars. Theriogenology. 70:1297-1303.

Gadea, J. 2005. Sperm factors related to in vitro and in vivo porcine fertility. Theriogenology. 63:431-444.

Garcia-Tomás, M., J. Sanchez, O. Rafel, J. Ramon, and M. Piles. 2006. Reproductive performance of crossbred and purebred male rabbits. Livest. Sci. 104:233-243.

Garcia-Tomas, M., L. Tusell, M. López-Béjar, J. Ramon, O. Rafel, and M. Piles. 2008. Influence of environmental temperature and relative humidity on quantitative and qualitative semen traits in rabbits. Proc. 9th World Rabbit Congr. (Verona) 72:111.

Geweke, J. 1992. Evaluating the accuracy of sampling-based approaches to the calculation of posterior moments. Oxford Univ. Press, Oxford, UK.

Geyer, C. J. 1992. Practical markov chain monte carlo. Stat. Sci. 7: 473-511.

Gómez, E. A., O. Rafel, and J. Ramon. 2002. The Caldes strain (Spain). Options Méditerr. B Études et Rech. 38:193-198.

Hansen, P. J. 2009. Effects of heat stress on mammalian reproduction. Phil. Trans. R. Soc. B. 364:3341-3350.

Hansen, P. J., M. Drost, R. M. Rivera, F. F. Paula-Lopes, Y. M. Al-Katanani, C. E. Krininger, and C. C. Chase. 2001. Adverse impact of heat stress on embryo production: Causes and strategies for mitigation. Theriogenology. 55:91-103.

Harkness, J. E. 1988. Rabbit behaviour as related to environmental stress. J. Appl. Rabbit Res. 11:227-236.

Harper, M. J. K. 1963. Ovulation in the rabbit: The time of follicular rupture and expulsion of the eggs, in relation to injection of luteinizing hormone. J. Endocrinol. 26:307-316.

Harper, M. J. K. 1973a. Relationship between sperm transport and penetration of eggs in the rabbit oviduct. Biol. Reprod. 8:441-450.

Harper, M. J. K. 1973b. Stimulation of sperm movement from the isthmus to the site of fertilization in the rabbit oviduct. Biol. Reprod. 8:369-377. 
Hill, M., and W. E. White. 1933. The growth and regression of follicles in the œstrous rabbit J. Physiol. 80:174-178.

Ho, H., and S. Suarez. 2001. Hyperactivation of mammalian spermatozoa: Function and regulation. Reproduction. 122:519-526.

Howarth, B., Jr, C. W. Alliston, and L. C. Ulberg. 1965. Importance of uterine environment on rabbit sperm prior to fertilization. J. Anim Sci. 24:1027-1032.

Hunter RH, Bogh IB, Einer-Jensen N, Müller S, Greve T. 2000. Pre-ovulatory Graafian follicles are cooler than neighbouring stroma in pig ovaries. Hum Reprod. 15:273-283.

Lavara, R., E. Moce, F. Lavara, M. P. V. de Castro, and J. S. Vicente. 2005. Do parameters of seminal quality correlate with the results of on-farm inseminations in rabbits? Theriogenology 64: $1130-1141$.

Lee, K. Y., and F. J. De Mayo. 2004. Animal models of implantation. Reproduction 128:679-695.

Maertens, L., F. Luzi, and G. Grilli. 1995. Effects of PMSG induced oestrus on the performances of rabbit does: A review. World Rabbit Sci. 3:191-199.

Makarevich, A. V., L. Olexikova, P. Chrenek, E. Kubovicova, K. Freharova, and J. Pivko. 2007. The effect of hyperthermia in vitro on vitality of rabbit preimplantation embryos. Physiol. Res. 56:789-796.

Marai, I. F. M., A. A. Askar, and L. B. Bahgat. 2006. Tolerance of New Zealand white and Californian doe rabbits at first parity to the sub-tropical environment of Egypt. Livest. Sci. 104:165-172.

Marai, I. F. M., A. A. M. Habeeb, and A. E. Gad. 2002. Rabbits' productive, reproductive and physiological performance traits as affected by heat stress: A review. Livest. Prod. Sci. 78:7190.

Nomina Embryologica Veterinaria. 1994. International Committee on Veterinary Embryological Nomenclature. Zurich and Ithaca, New York.

Overstreet, J. W., and G. W. Cooper. 1978. Sperm transport in the reproductive tract of the female rabbit: II. The sustained phase of transport. Biol. Reprod. 19:115-132.

Piles, M., M. L. Garcia, O. Rafel, J. Ramon, and M. Baselga. 2006. Genetics of litter size in three maternal lines of rabbits: Repeatability versus multiple-trait models. J. Anim. Sci. 84:23092315.

Piles, M., O. Rafel, J. Ramon, and L. Varona. 2005. Genetic parameters of fertility in two lines of rabbits with different reproductive potential. J. Anim. Sci. 83:340-343.

Prud'hon, M. 1970. La reproduction des lapins. La revue de l'élevage. Numéro spécial: La production moderne des viandes de poulet et de lapin. 47:407-411.

Prud'hon, M. 1975. Le comportamnet alimentaire du lapin dépend beaucup de l'abreuvement. Elevage, № nors série: une production d'avenir - Le lapin, 55-59.

Putney, D. J., M. Drost, and W. W. Thatcher. 1988. Embryonic development in superovulated dairy cattle exposed to elevated temperatures between days 1 to 7 after insemination. J. Reprod. Biol. 39:717-728.

Raftery, A. E., and S. Lewis (Editors). 1992. How many iterations in the Gibbs Sampler? Bayesian Statistics 4. Oxford Univ. Press, NY.

Roca, J., S. Martínez, J. Orengo, I. Parrilla, J. M. Vázquez, and E. A. Martínez. 2005. Influence of constant long days on ejaculate parameters of rabbits reared under natural environment conditions of Mediterranean area. Livest. Prod. Sci. 94:169-177.

Roth, Z. 2008. Heat stress, the follicle, and its enclosed oocyte: Mechanisms and potential strategies to improve fertility in dairy cows. Reprod. Domestic Anim. 43:238-244. 
Saacke, R. G., J. C. Dalton, S. Nadir, R. L. Nebel, and J. H. Bame. 2000. Relationship of seminal traits and insemination time to fertilization rate and embryo quality. Anim. Reprod. Sci. 60:663-677.

Swierstra, E. E., and R. H. Foote. 1965. Duration of spermatogenesis and spermatozoan transport in the rabbit based on cytological changes, DNA synthesis and labeling with tritiated thymidine. Wiley Subscription Services, Inc., A Wiley Company. 116:401-411.

Tusell, L., M. Garcia-Tomas, M. Baselga, R. Rekaya, O. Rafel, J. Ramon, M. Lopez-Bejar, and M. Piles. 2010a. Interaction of genotype $\mathrm{x}$ artificial insemination conditions for male effect on fertility and prolificacy. J. Anim Sci. 88:3475-3485.

Tusell, L., A. Legarra, M. Garcia-Tomas, O. Rafel, J. Ramon, and M. Piles. 2011. Different ways to model biological relationships between fertility and the ph of the semen in rabbits J. Anim Sci. Accepted.

Wright, S. 1934. An analysis of variability in number of digits in an inbred strain of Guinea pigs. Genetics 19:506-536.

Yassein, S. A., K. G. M. Mahmoud, N. Maghraby, and O. H. Ezzo. 2008. Hot climate effects and their amelioration on some productive and reproductive traits in rabbit does. World Rabbit Sci. 16:173-181 


\section{General discussion}

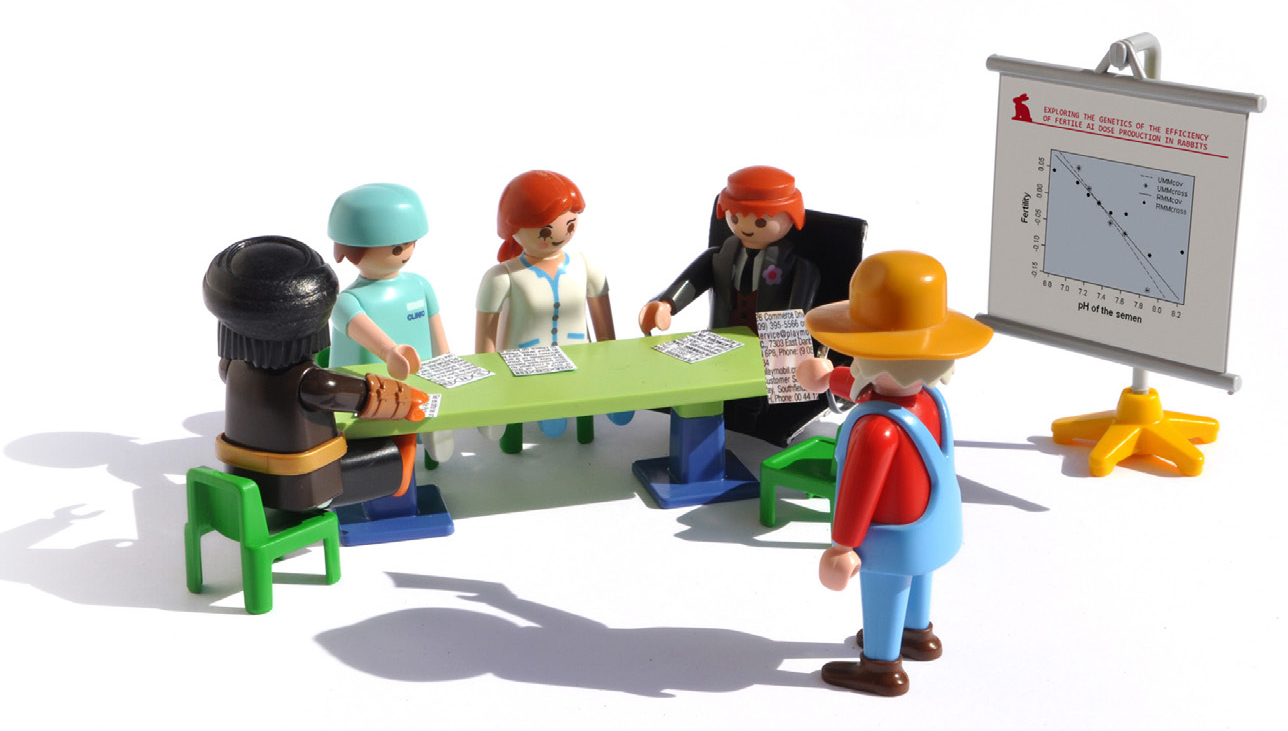


The widespread utilization of $\mathrm{AI}$ in rabbits has led to an extensive use of males for insemination. Bucks used for AI dose production are required to have not only good characteristics of growth and feed efficiency but also good reproductive performance.

Results obtained in this thesis agree with previous researches that the efficiency of dose production in the AI centres is suboptimal (Brun et al., 2002; Theau-Clément et al., 2003; Garcia-Tomás et al., 2006b). For example, the percentage of rejected ejaculates in our study reached 38\%. The criteria to accept ejaculates for $\mathrm{AI}$ include subjective assessments of quality traits of ejaculate and sperm. Some of these traits are associated with the presence of contaminants or residues in the ejaculate that preclude semen evaluation and utilization, such as the presence of urine, blood and some other residues. Other criteria are deficiencies in certain seminal characteristics such as sperm motility and presence of dead spermatozoa which are expected to have negative effects on male reproductive performance. In our study $66 \%$ of the rejected ejaculates showed low sperm motility, $32 \%$ contained calcium carbonate deposits, and $14 \%$ contained urine.

In addition to strong selection of ejaculates, $\mathrm{AI}$ in commercial farms is performed at high sperm dosage in order to overcome the negative effects on fertility of semen with suboptimal characteristics. This practice reduces the output of AI centres. However, this practice would be attenuated if the fertilizing potential of ejaculates were accurately predicted given their seminal characteristics or if the seminal characteristics were good enough to ensure a high reproductive performance even at low sperm dosage. Deciding which set of seminal characteristics to measure and what levels of those are optimal is difficult. Thus, direct genetic improvement of male reproductive performance implies improving this set of seminal characteristics that are important for obtaining fertile doses.

Production of AI doses also depends on the total number of sperm in each ejaculate, which is the product of ejaculate volume and sperm concentration. For example, only approximately 9 doses per ejaculate are obtained from Caldes line bucks at a commercial concentration of $40 \mathrm{x}$ $10^{6}$ spermastozoa/mL.

In order to know the feasibility of genetic improvement of the efficiency of fertile dose production, the genetic determinism of its components has been assessed in this thesis. The analyzed traits were: male libido and the characteristics involved in the ejaculate rejection criteria, semen production traits, and male reproduction performance (i.e. male contribution to fertility and prolificacy). The last one is considered to be the final expression of all seminal characteristics and the interaction among them and with the female.

The $\mathrm{h}^{2}$ for male libido and the characteristics involved in the ejaculate rejection criteria such as individual sperm motility, presence of urine and calcium carbonates deposits in the ejaculate ranged from 0.04 to 0.08 . Of special interest is the $h^{2}$ of the presence of calcium 
carbonate deposits in the ejaculate, which causes a lot of ejaculate rejections in the Caldes line, and was estimated to be 0.08 (HPD $95 \%: 0.04,0.12$ ). Thus, as genetic determinism of those traits is small, the expected response to genetic selection for increasing the number of ejaculates that can be obtained per male and the time consumed for it, as well as the reduction of the ejaculate rejection rate is small. Therefore, management practices rather than genetic selection would be more advisable to improve those traits.

Sperm production traits (concentration, volume and total number per ejaculate) showed moderate $\mathrm{h}^{2}$. The genetic correlation between sperm concentration and ejaculate volume was -0.53 (HPD95\%:-0.76, -0.27), which agrees with most of the estimates in other livestock species (Ducrocq and Humblot, 1995; David et al., 2007; Furstoss et al., 2009; Wolf and Smital, 2009). Thus selection to increase semen production could be effective.

Although it is not a trait routinely measured in AI centres, semen pH was investigated because it can be considered to be a global marker of some seminal quality traits with direct effect on fertility, such as sperm motility and concentration (Brun et al., 2002; Garcia-Tomás et al., 2006a). Semen $\mathrm{pH}$ is fast and cheap to measure and therefore could be included in the criterion for ejaculate rejection. The feasibility of indirect selection of male fertility through the use of this seminal trait has been studied taking into account a possible non-linear relationship between those traits, as well as a possible recursive effect of semen $\mathrm{pH}$ on fertility. The effect of semen $\mathrm{pH}$ on the phenotypic expression of fertility has already been described (More O'Ferrall and Meacham, 1968; Brun et al., 2002) but in turn, this trait also has genetic and permanent effects contributing to its phenotypic expression which could lead to a recursive effect of this trait on male fertility. Biased (co)variance estimates can be obtained if recursive relationships between traits are not taken into account (Gianola and Sorensen, 2004). The considered models included semen $\mathrm{pH}$ either as a covariate or as a cross-classified effect and they were recursive or classical univariate or bivariate models. Models were compared according to their ability to predict fertility data and the across-model EBV correlations. Ratios for genetic and environmental sources of variation were also estimated for both $\mathrm{pH}$ and fertility in all the models. Results agree with previous studies that semen $\mathrm{pH}$ had a clear negative an almost linear effect on fertility. This effect was equally estimated by using either recursive or classical multivariate models. Both types of models predict fertility data reasonably well. Moreover, genetic parameters estimates were similar across models. The fact that models were almost equivalent despite differing in complexity may be due to small recursiveness effect of $\mathrm{pH}$ on fertility encountered and the low precision obtained for the parameter estimates. For example, the posterior means of the genetic correlations ranged from -0.41 to -0.17 across models, but the credible regions of these estimates were very wide. The $\mathrm{h}^{2}$ of semen $\mathrm{pH}$ was estimated in this study for the pooled semen obtained from each male in the day of collection, but it was also estimated for individual ejaculates in another study of 
this thesis when the genetic determinism of the traits included in the ejaculate rejection criteria was assessed. In both cases $\mathrm{pH}$ was found to be low to moderately heritable $(0.11$ for individual ejaculates and 0.18 for the pool of the ejaculates). The repeatability was also moderate: 0.32 and 0.23 for single and pooled semen, respectively. Considering the low $\mathrm{h}^{2}$ estimates of semen $\mathrm{pH}$ and its moderate genetic correlation with fertility, indirect selection of male fertility via semen $\mathrm{pH}$ is not recommended.

The efficiency of fertile dose production is improved if semen quality traits are good enough to allow performing the AI at low sperm dosage without impairing reproductive performance (because it implies producing more doses per ejaculate). Improving the male contribution to reproductive performance is also a way to improve the seminal components that have a favourable effect on fertility and prolificacy.

In this thesis two models were used for analysing fertility after AI and their performance compared. We used the product threshold model which was developed in the animal breeding context by David et al. (2009) as an alternative to an additive threshold model for analyzing binary AI results. Both, the product and additive threshold models showed similar ability to predict an independent set of fertility data. For example, the percentage of wrong predictions was 38\% in both models and they also did not differ in the mean square error of the prediction, the sensitivity and specificity of the prediction and in the positive and negative predicted values obtained. One of the advantages of the product threshold model with respect to the additive threshold model is that it extracts more information from data. For example, it allows calculating the probabilities of fertility success for each sex and it allows evaluating which sex is responsible for an AI failure. In rabbits, male and female probabilities of a fertility success were similar and high (87\% and $83 \%)$ and the percentages of AI failure specifically due to male and female fertility problems were $39 \%$ and $54 \%$, respectively. Although estimates of the genetic correlation between male and female contributions to fertility were imprecise, both models showed similar values: 0.21 and 0.31 for the product and the additive model, respectively. However, interpretation of some of the parameter estimates obtained with the product threshold model (e.g. $\mathrm{h}^{2}$ and variance components) is not straightforward and cannot be compared with the corresponding figures obtained with the additive threshold model. The $\mathrm{h}^{2}$ for the male contribution to fertility was 0.17 and 0.04 in the product and additive threshold model, respectively. The correlation between the EBV for male and female contributions to fertility obtained in each model were close to 1 and the percentage of animals in common in the top $10 \%$ best/worst animals was high (more than $76 \%$ ) in both models. Hence, from the point of view of selection in rabbits, irrespective of the model of choice, small changes in the evaluation of the individuals for fertility would be encountered. 
Previous studies concerning reproductive performance after natural mating in rabbit reported an almost null male contribution (Piles et al., 2005; Piles et al., 2006). However, it is possible that individual variation among males for fertility after natural mating cannot be observed because the number of sperm in the ejaculate is very large and most males exceeded the threshold needed to reach fertility (Amann and Hammerstedt, 2002). Thus, although differences among males that are independent of sperm dosage are maintained, differences among males that can, at least in part, be overcome by increasing the amount of sperm are not detected (Saacke et al., 2000). Our results confirm a similar effect when AI is performed at high sperm dosage. Reducing the number of sperm in the dose could lead to better observe differences in reproductive performance among males. This would be a specific case of the existence of an interaction between the male genotype and the sperm dosage. Other factors involved in the AI process as a whole e.g. conditions and duration of dose storage, female genotype and environmental conditions on the farm could also lead to an interaction with the male genotype. In this thesis, we have used the character state model to test if there is an interaction between male genotype and AI conditions for male contribution to fertility and prolificacy. In a first study using stored doses, the AI conditions were determined uniquely by sperm concentration of AI dose (10 vs $40 \times 10^{6}$ spermatozoa/mL). In a second study, the AI conditions were determined by all factors involved in $\mathrm{AI}$ as a whole. AI data from two different farms with different doe genotypes and with different types of doses (fresh vs. stored, different sperm concentrations, different extenders, etc) were analysed.

Male contributions to fertility and litter size after AI were low but higher in magnitude than the ones obtained after natural mating. Male $\mathrm{h}^{2}$ for fertility after AI was higher than the corresponding value obtained after natural mating in the same line of rabbits (Piles et al., 2005). Moreover, male $h^{2}$ for prolificacy was higher than the male effect estimated in three maternal lines of rabbits (Piles et al., 2006). Results suggest that there is a clear effect of sperm concentration on male fertility and prolificacy. However, almost no genetic determinism is involved in this effect. Therefore, selection to improve male reproductive performance after AI could be done regardless of seminal concentration, at least within the range of sperm dosage used in this study and using stored doses. Under these conditions, response to selection could be greater than the expected response after natural mating or AI with fresh doses because the male additive variance obtained for both traits was greater. On the other hand, an interaction could exist between the male genotype and AI conditions for male effect on fertility and prolificacy, such as the time and storage conditions of the AI doses, the female genotype, or the environment. There could be a scale effect because of differences in the magnitude of the additive variances for male fertility and prolificacy after AI in the two AI conditions. Moreover, rankings of male EBV for those traits could differ depending on AI conditions because genetic correlations of fertility and prolificacy after $\mathrm{AI}$ at different conditions could be said to be 
different from 1 (the probability of a genetic correlation of being less than 0.75 was $83 \%$ for male fertility and $100 \%$ for male prolificacy). The existence of this interaction also implies that the conditions that give the maximum genetic progress could be chosen to optimize the breeding program for male reproductive performance under given conditions of semen utilization. However, despite of obtaining higher response under optimal AI conditions than under AI conditions of semen utilization (e.g., the commercial conditions), the superiority of the selected individuals with respect to the average population in the current conditions of semen utilization would be still reduced due to a scale effect, which might not compensate the investment required for selection (Kolmodin, 2003). However, a favourable correlated response could be obtained in semen quality traits leading to a higher production of fertile doses per ejaculate if selected males are used in the AI centres.

Finally, if part of the interaction between the male genotype and AI conditions is due to the effect of time and storage conditions of the AI doses, then any existing differences among males in the ability to maintain seminal characteristics after storage might also result in differences in their fertilization potential. Thus, it could be possible to change the sensitivity of sperm to conservation with genetic selection.

It is necessary for genetic improvement of the efficiency of fertile dose production to know the $\mathrm{h}^{2}$ of seminal traits but also their genetic correlations with the selection criteria of paternal lines in order to determine if there is an antagonism between them. In this thesis all the research was conducted by using bucks from the Caldes line selected for growth rate during the fattening period. Thus, the genetic relationships between male libido and some of the seminal traits involved in the production of doses with growth rate were estimated. Our results show that growth rate has a slightly favourable genetic correlation with sperm concentration, slightly unfavourable with ejaculate volume and is genetically uncorrelated with the remaining seminal traits and male libido.

Fertility seems to be not affected by the selection for growth in the Caldes line. The genetic correlation between female contribution to fertility and growth rate was low (-0.13; Tusell et al., 2009) and male and female contributions to fertility seem to have a moderate to high positive genetic correlation after AI (as it has been detailed above) or after natural mating (0.73; Piles et al., 2005). Therefore, selection for increasing average daily gain is not expected to have detrimental correlated effects on male fertility. Recent analyses support this statement since the estimates of the genetic correlation between growth rate and the male and female contributions to fertility were found to be negligible (not published results).

Among the seminal traits analyzed, the most interesting one to select for in order to increase the sperm production would be the total number of sperm produced per ejaculate because it 
includes ejaculate volume and sperm concentration and it determines the total amount of doses that can be prepared per ejaculate.

In addition, it seems also feasible to improve the efficiency of the production of potentially fertile doses of the bucks of this paternal line of rabbits selecting for the male contribution to fertility evaluated after using optimal AI conditions of maximization of the genetic progress. Further research is necessary to evaluate the effect on selection of including any of these two traits in an index with average daily gain. This future research should explore responses to selection in different scenarios.

Moreover, different magnitudes of genetic variation for male reproductive performance have been encountered depending on the type of AI conditions used. This suggest that the response to selection for reproductive performance traits in rabbits could be improved by including, jointly with the female additive effect, a male additive effect predicted from information obtained from AI performed under limited AI conditions.

Finally, the last study of this thesis has aimed to determine the critical periods around the AI time in which the environmental temperature has a major effect on male and female contributions to fertility. To achieve that, we have used the product threshold model as it allows providing specific estimates of the effects affecting each one of the members involved in an AI outcome. Temperature effects at different periods of time around insemination on male and female fertility have been estimated. We conclude that temperature of the AI day seems to have the most relevant effect on male contribution to fertility, since high temperature in the AI day impaired this trait. This effect could be indicative of the high sperm sensitivity to temperature changes during the processes of preparation and application of the $\mathrm{AI}$ doses, as well as the temperature effect on some sperm physiological processes occurring around the fertilization time. Departures from the neutral thermal zone the days previous to insemination and up until early gestation had a negative effect on female fertility. Among them, the most temperature sensitive periods were the pre and peri-implantational stages of the embryos. The latest period of gestation seemed to be unaffected by the temperature confirming the results previously described in other studies about the gain of thermotolerance reached in the latest stages of gestation (Ealy et al., 1993; Hansen et al., 2001). Hence, the product threshold model allowed us to estimate that male and female fertility are specifically affected by temperature in different periods around the insemination time. However, the magnitude and the persistency of the temperatures reached in the commercial conditions of this study do not seem to have a large effect on male and female rabbit fertility. From the practical point of view, it seems to be advisable to handle sperm to be used for AI in a rapid and careful manner in order to not to compromise its fertilizing ability. 


\section{Literature cited}

Amann, R. P., and R. H. Hammerstedt. 2002. Detection of differences in fertility - andrology lab corner. J. Androl. 23: 317-325.

Brun, J. M., M. Theau-Clement, and G. Bolet. 2002. The relationship between rabbit semen characteristics and reproductive performance after artificial insemination. Anim. Reprod. Sci. 70: $139-149$.

David, I., L. Bodin, D. Gianola, A. Legarra, E. Manfredi, and C. Robert-Granie. 2009. Product versus additive threshold models for analysis of reproduction outcomes in animal genetics. J. Anim. Sci. 87: 2510-2518.

David, I., X. Druart, G. Lagriffoul, E. Manfredi, C. l. Robert-GraniÃ $@$, and L. Bodin. 2007. Genetic and environmental effects on semen traits in lacaune and manech tête rousse ai rams. Genet. Sel. Evol. 39: 405-419.

Ducrocq, V., and P. Humblot. 1995. Genetic characteristics and evolution of semen production of young normande bulls. Livestock Production Science 41: 1-10.

Ealy, A. D., M. Drost, and P. J. Hansen. 1993. Developmental changes in embryonic resistance to adverse effects of maternal heat stress in cows. J. Dairy Sci. 76: 2899-2905.

Furstoss, V., I. David, B. Leboeuf, P. Guillouet, P. Boue, and L. Bodin. 2009. Genetic and nongenetic parameters of several characteristics of production and semen quality in young bucks. Anim. Reprod. Sci. 110: 25-36.

Garcia-Tomás, M., J. Sanchez, O. Rafel, J. Ramon, and M. Piles. 2006a. Reproductive performance of crossbred and purebred male rabbits. Livest. Sci. 104: 233-243.

Garcia-Tomás, M., J. Sanchez, O. Rafel, J. Ramon, and M. Piles. 2006b. Variability, repeatability and phenotypic relationships of several characteristics of production and semen quality in rabbit. Anim. Reprod. Sci. 93: 88-100.

Gianola, D., and D. Sorensen. 2004. Quantitative genetic models for describing simultaneous and recursive relationships between phenotypes. Genetics 167: 1407-1424.

Hansen, P. J., M. Drost, R. M. Rivera, F. F. Paula-Lopes, Y. M. Al-Katanani, C. E. Krininger, and C. C. Chase. 2001. Adverse impact of heat stress on embryo production: Causes and strategies for mitigation. Theriogenology. 55: 91-103.

Kolmodin, R. 2003. Reaction norms for the study of genotype by environment interaction in animal breeding. Phd diss. Dept. Of animal breeding and genetics. Swedish univ. Of agricultural sciences. Uppsala.

More O'Ferrall, G. J., and T. N. Meacham. 1968. Relationship between ph, other semen traits and fertility in rabbits. VI ${ }^{6}$ Cong. Intern. Reprod. Anim. Insem. Artif. Paris 2: 1279-1281.

Piles, M., M. L. Garcia, O. Rafel, J. Ramon, and M. Baselga. 2006. Genetics of litter size in three maternal lines of rabbits: Repeatability versus multiple-trait models. J. Anim. Sci. 84: 23092315.

Piles, M., O. Rafel, J. Ramon, and L. Varona. 2005. Genetic parameters of fertility in two lines of rabbits with different reproductive potential. J. Anim. Sci. 83: 340-343.

Saacke, R. G., J. C. Dalton, S. Nadir, R. L. Nebel, and J. H. Bame. 2000. Relationship of seminal traits and insemination time to fertilization rate and embryo quality. Anim. Reprod. Sci. 60: 663-677.

Theau-Clément, M., J. M. Brun, E. Sabbioni, C. Castellini, T. Renieri, U. Besenfelder, J. Falieres, J. Esparbie, and G. Saleil. 2003. Comparaison de la production spermatique de trois souches de lapins: Moyennes et variabilités. 10èmes Journ. Rech. Cunicole, Paris, France.: 81-84. 
Tusell, L., O. Rafel, J. Ramon, and M. Piles. 2009. Genetic analysis of fertility and average daily gain in rabbit EAAP- 60th Annual Meeting of the European Federation of Animal Science EAAP, 2009, Barcelona, Spain. 15: 172-172.

Wolf, J., and J. Smital. 2009. Quantification of factors affecting semen traits in artificial insemination boars from animal model analyses. J. Anim Sci. 87: 1620-1627 


\section{Final \\ conclusions}

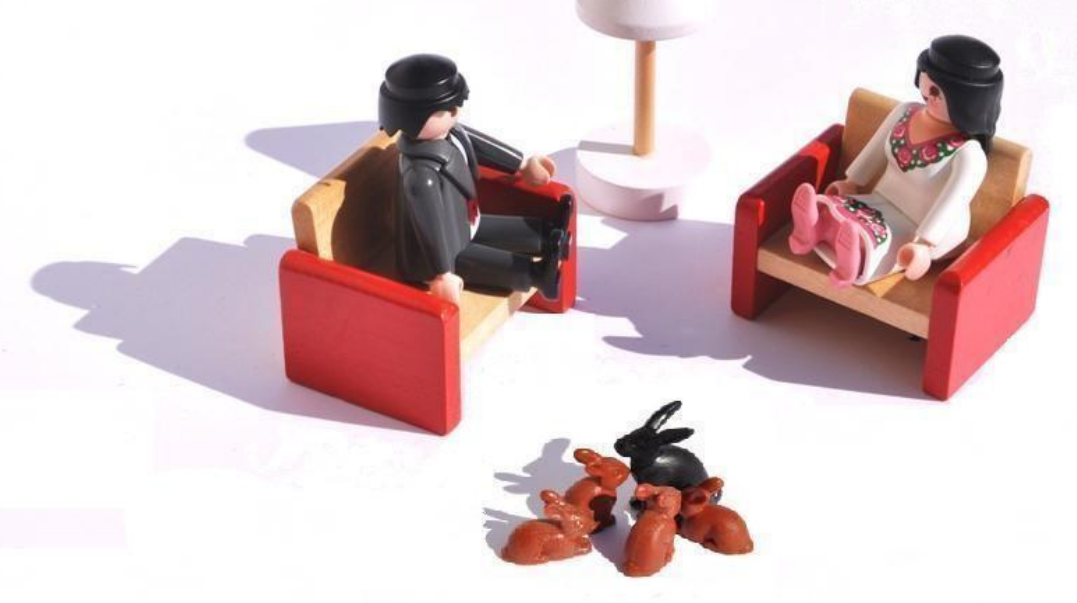


In this thesis, sources of variation for some of the most important components of fertile AI dose production have been determined in order to explore the interest and limitations of different strategies for their genetic improvement. Final conclusions of this thesis are:

1. Male libido and the characteristics of the ejaculate involved in the rejection criteria used in the AI centres for discarding ejaculates for AI have low genetic determinism precluding their improvement through genetic selection.

2. Seminal production traits were found to be heritable indicating that selection to increase semen production could be effective.

3. Semen $\mathrm{pH}$ could be used in the AI centres to select qualitative better ejaculates to increase dose fertility. However, indirect genetic selection of male fertility through semen $\mathrm{pH}$ could not be effective.

4. The observed genetic variation for male contribution to fertility and prolificacy after AI with stored semen was higher than after natural mating.

5. Selection to improve male reproductive performance could be done at any sperm concentration of the AI dose within the range of 10 and $40 \times 10^{6}$ spematozoa $/ \mathrm{mL}$.

6. Response to selection could be greater for male reproductive performance after AI with stored doses than the response to selection after natural mating or after AI with fresh semen.

7. Optimal AI conditions could be chosen to maximize the genetic progress for male contributions to fertility and prolificacy for given conditions of semen use.

8. Components involved in fertile AI dose production have an almost null genetic correlation with growth rate.

9. High environmental temperature of the day of AI has a detrimental effect on male contribution to fertility whereas departures from the neutral thermal zone the days previous to insemination and up until early gestation had also a negative effect on female contribution to fertility 


\section{Conclusions finals}

En aquesta tesi s'han analitzat les fonts de variació d'alguns dels components més importants involucrats en la producció de dosis d'IA fèrtils amb la finalitat d'explorar l'interès i les limitacions de les diferents estratègies de selecció per a la seva millora genètica.

Les conclusions finals d'aquesta tesi són:

1. La libido del mascle i les característiques de l'ejaculat que s'utilitzen en els centres d'inseminació com a criteri per rebutjar els ejaculats per a IA tenen un baix determinisme genètic impossibilitant la seva millora mitjançant la selecció genètica.

2. Els caràcters de producció seminal són heretables indicant que la selecció per la millora de la producció de semen pot ser efectiva.

3. El pH del semen pot ser utilitzat en els centres d'IA per seleccionar qualitativament els ejaculats per tal d'incrementar la fertilitat de la dosi. Tanmateix, la selecció indirecta de la fertilitat del mascle a través del $\mathrm{pH}$ de semen podria no ser efectiva.

4. La variació genètica observada de la contribució del mascle a la fertilitat i a la prolificitat en IA és més alta que en munta natural.

5. La selecció per a millorar el rendiment reproductiu del mascle es pot fer a qualsevol concentració espermàtica dins del rang de 10 a 40 x106 espermatozous $/ \mathrm{mL}$.

6. La resposta a la selecció per la millora del rendiment reproductiu del mascle podria ser major amb IA amb dosis conservades que la resposta corresponent amb munta natural o amb IA amb semen fresc.

7. Seria possible escollir les condicions d'IA òptimes per maximitzar el progrés genètic per a les contribucions del mascle a la fertilitat i a la prolificitat per a unes determinades condicions d'ús del semen.

8. Els components involucrats en la producció de dosis fèrtils tenen una correlació genètica pràcticament nul·la amb la velocitat de creixement.

9. Una temperatura ambiental elevada el dia de la IA té un efecte perjudicial en la contribució a la fertilitat del mascle mentre que allunyaments de la zona de termoneutralitat els dies previs a la inseminació i fins als primers estadis de gestació també tenen un efecte negatiu en la contribució de la femella a la fertilitat. 


\section{Conclusiones finales}

En esta tesis se han analizado las fuentes de variación de algunos de los componentes más importantes involucrados en la producción de dosis fértiles con la finalidad de explorar el interés y las limitaciones de diferentes estrategias de selección para su mejora genética.

Las conclusiones finales de esta tesis són:

1. La libido del macho y las características del eyaculado utilizadas en el centro de IA para descartar los eyaculados para ser usados en inseminación tienen un determinismo genético bajo imposibilitando su mejora mediante la selección genética.

2. Los caracteres de producción seminal son heredables indicando que la selección para la mejora de la producción de semen puede ser efectiva.

3. El pH del semen puede ser utilizado en los centros de IA para seleccionar cualitativamente los eyaculados para incrementar la fertilidad de la dosis. Sin embargo, la selección indirecta de la fertilidad del macho a través del pH del semen podría no ser efectiva.

4. La variación genética observada de la contribución del macho a la fertilidad y a la prolificidad tras la IA es más alta que tras la monta natural.

5. La selección para mejorar el rendimiento reproductivo del macho puede llevarse a cabo a cualquier concentración espermática dentro del rango de 10 a 40 x106 espermatozous $/ \mathrm{mL}$.

6. La respuesta a la selección para la mejora del rendimiento reproductivo del macho podría ser mayor tras la IA con dosis conservadas que la respuesta correspondiente tras la monta natural o tras la IA con semen fresco.

7. Sería posible escoger las condiciones de IA óptimas para maximizar el progreso genético para las contribuciones del macho a la fertilidad y a la prolificidad para unas determinadas condiciones de uso del semen.

8. Los componentes involucrados en la producción de dosis fértiles tienen una correlación genética prácticamente nula con la velocidad de crecimiento.

9. Una temperatura ambiental elevada el día de IA tiene un efecto perjudicial en la contribución a la fertilidad del macho mientras que alejamientos de la zona de termoneutralidad durante los días previos a la inseminación hasta los primeros estadios de gestación también tienen un efecto negativo en la contribución de la hembra a la fertilidad. 


\section{Implications}

Genetic selection for improving male reproductive performance under the current commercial AI conditions would lead to a limited response either using direct selection or indirect selection through the use of the seminal traits used in the AI centres nowadays. However, given that an interaction between genotype and AI conditions could exist, it would be possible to find the AI conditions which maximize the genetic progress of male reproductive performance for a given conditions of semen utilization. Further research is needed in order to find the main responsible factors of this interaction.

Achieving suitable genetic progress for semen production seems to be possible. However, it is necessary to first stablish the genetic relationship between semen production and quality in order to not impair the fertilizing ability of AI doses, and also to know the economic weights for these traits.

The predictive ability of male reproductive performance from semen quality traits could be improved if it is possible to find variables and laboratorial tests which are better markers of fertility than the ones currently used in the AI centers to evaluate seminal samples. Finding new statistical methods with better predictive ability than multiple regression would contribute to rightly score the ejaculates according to their fertilizing potential

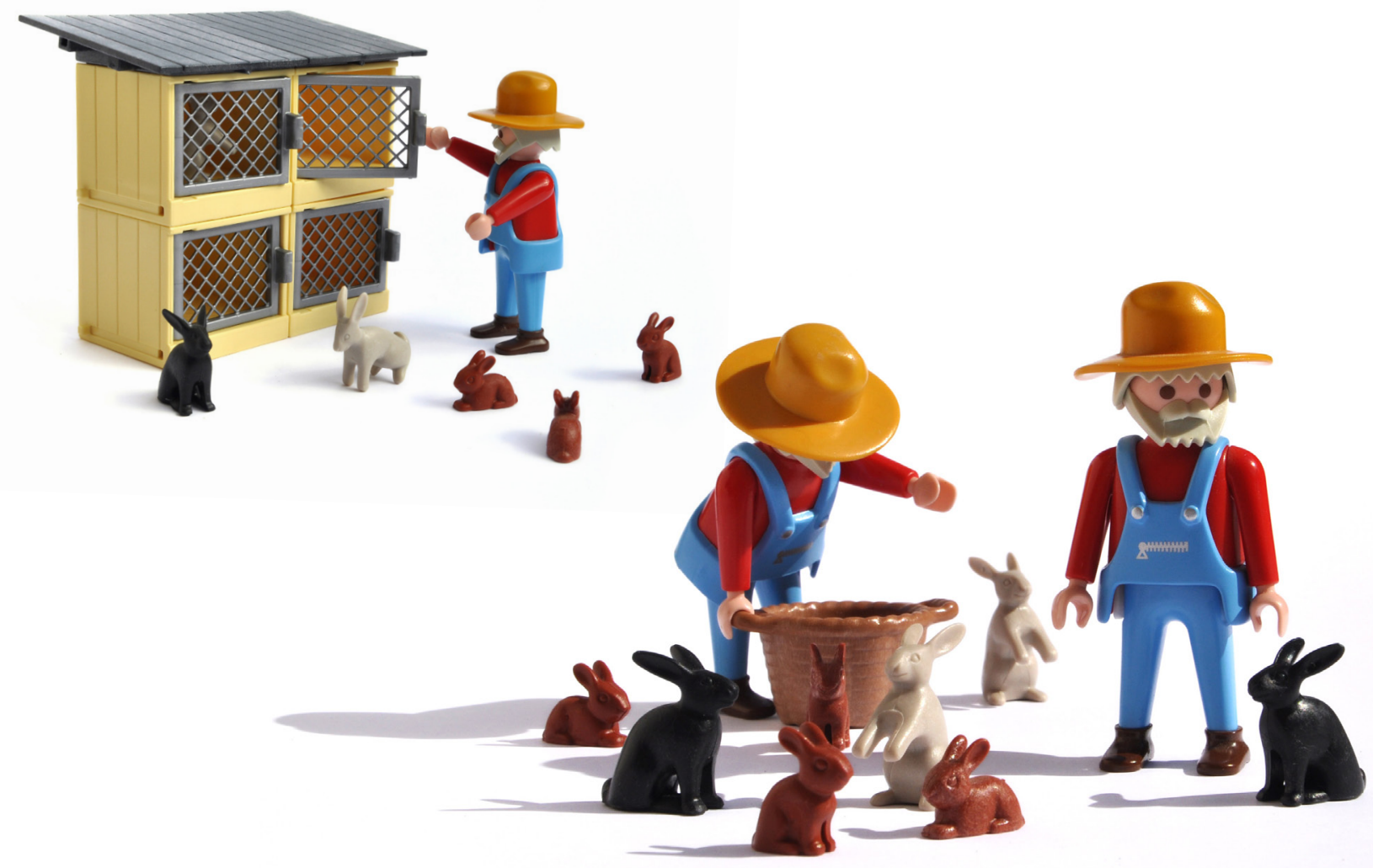




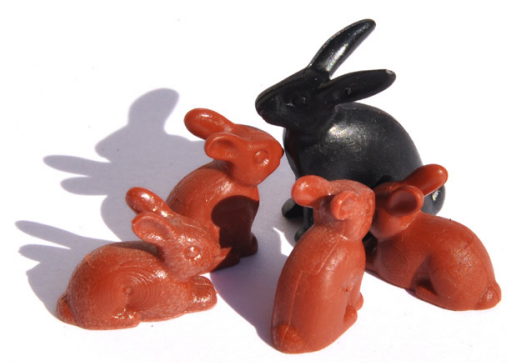

APPENDIX 


\section{JOURNAL OF ANIMAL SCIENCE}

The Premier Journal and Leading Source of New Knowledge and Perspective in Animal Science

\section{Product versus additive model for studying artificial insemination results in several livestock populations}

I. David, M. J. Carabaño, L. Tusell, C. Diaz, O. González-Recio, E. López de Maturana, M.

Piles, E. Ugarte and L. Bodin

J Anim Sci 2011.89:321-328.

doi: 10.2527/jas.2010-3167 originally published online Oct 15, 2010;

The online version of this article, along with updated information and services, is located on the World Wide Web at:

http://jas.fass.org/cgi/content/full/89/2/321 


\title{
Product versus additive model for studying artificial insemination results in several livestock populations
}

\author{
I. David, ${ }^{* 1}$ M. J. Carabaño, $\dagger$ L. Tusell, $\$$ C. Diaz, $\uparrow$ O. González-Recio, $\uparrow$ \\ E. López de Maturana, $\uparrow$ M. Piles,$\ddagger$ E. Ugarte,$\S$ and L. Bodin*
}

*INRA UR 631 Station d'Amélioration Génétique des Animaux, 31320 Castanet-Tolosan, France; $\dagger$ Departamento de Mejora Genética Animal, INIA, Carretera de La Coruña km 7.5, 28040 Madrid, Spain; $\ddagger$ Unitat de Cunicultura, Institut de Recerca i Tecnologia Agroalimentàries, Torre Marimon s/n, 08140, Caldes de Montbui, Barcelona, Spain; and §Neiker, 01000 Vitoria-Gasteiz, Spain

\begin{abstract}
Two models can be used for studying binary results of AI. The additive threshold model proposes an underlying variable as summing the environmental and genetic effects from the 2 individuals involved in the mating, and the product threshold model assumes that the conditional probability of AI success is the product of the probabilities of success of 2 unobserved binary phenotypes (one is the male fertility; the other is the female fertility). The purpose of this paper is to compare the predictive ability of the product and the additive threshold models for studying AI results and to compare results obtained with the 2 models in 3 different species: cattle, sheep, and rabbits. Results showed that the predictive ability of the product model is similar to the additive model in sheep and rabbits but worst in cattle (percentage of wrong prediction = 42,27 , and $35 \%$ in the additive model; 43, 28, and $47 \%$ in the product model in sheep, rabbits, and cattle,
\end{abstract}

respectively). Even when the 2 models have similar performance, they differed in their EBV (for instance, Pearson correlation between EBV predicted with the 2 models $=0.46$ in sheep for male fertility). The product model can determine which sex is responsible for an AI failure. In sheep, the female was the responsible in $94 \%$ of the cases and male in $2 \%$ of them; in rabbits, the female was the responsible in $54 \%$ of the cases and the male in $39 \%$ of them. Different estimates of probabilities for male and female fertility success obtained with the product model in the 3 species suggest that male and female fertilities behave differently depending on the species and the uniqueness of the data sets. Although product model seems to provide additional information in the fertility process, further research is needed to understand the worst performance of the product model in cattle.

Key words: additive model, fertility, predictive ability, product model

(C)2011 American Society of Animal Science. All rights reserved.

J. Anim. Sci. 2011. 89:321-328 doi:10.2527/jas.2010-3167

\section{INTRODUCTION}

The outcome of AI is affected by factors related to the male, the female, or factors common to both sexes. The outcome of AI may be registered as a binary code indicating pregnancy or nonpregnancy. The most common approach in animal genetic models for such a binary trait is the additive threshold model, which proposes a underlying variable resulting from the addition of environmental and genetic effects from the 2 individuals involved in the mating (Varona and Noguera, 2001; Piles et al., 2005). However, some authors have pointed out that the combination of those sources of variation may

\footnotetext{
${ }^{1}$ Corresponding author: Ingrid.David@toulouse.inra.fr Received May 18, 2010.

Accepted October 7, 2010.
}

not be purely additive (Speirs et al., 1983). Recently, David et al. (2009) proposed a product threshold model assuming that conception in a given mating is the product of the outcome of each mating member. Hence, the conditional probability of AI success is the product of the probabilities of the success of 2 unobserved binary phenotypes (one is the male fertility; the other is the female fertility). This assumption has several advantages over that assumed in the additive model. First, it describes in a better manner the biological mechanism of the mating. Second, it provides distinct estimates of environmental effects affecting each of the 2 unobserved phenotypes, and as a result allows more information to be extracted from the data. David et al. (2009) showed the feasibility of this model in a genetic context using simulated data. However, the product threshold model has not been applied to real data yet. The purpose of this study was to compare the performance, in terms of 
predictive ability, of the product and additive threshold models for studying AI result and to compare results obtained with the 2 models in 3 data sets of different species: cattle, sheep, and rabbit. Differences between them originating not only from the specific characteristics of the species, but also from the different processes and conditions for AI (e.g., ejaculate selection, dose preparation, hormonal treatments) applied.

\section{MATERIALS AND METHODS}

Animal Care and Use Committee approval was not obtained for this study because the data were obtained from an existing database.

\section{Materials}

Artificial insemination data corresponding to the 3 species were used for the analysis (Table 1). Cattle data were provided by the regional Holstein Associations from Basque Country, Navarra, and Girona. Data were extracted from the November 2008 routine genetic evaluation for female fertility implemented in the north-western population of Spanish Holstein-Friesian cattle and included insemination records from 1995 to September 2008. As in most cattle populations, commercial frozen semen is used for AI in this population. Normally, bull semen is screened to discard ejaculates with low motility or abnormal sperm at collection or after freezing and thawing the samples. Bull ejaculates from the same day of collection are mixed and diluted in a proportion that ensures a minimum amount of motile spermatozoa in the AI straw. Estrus synchronization is becoming a frequent practice, but no recording of its incidence is carried out in this population. A service record was defined as success (1) if a subsequent calving existed and the corresponding gestation length period was within the interval 272 to 292 d. The insemination was considered as a failure (0) when additional inseminations within the same lactation existed or no subsequent calving was registered. Restrictions and rules for validating records were applied to ensure the quality of reproductive data following González-Recio and Alenda (2005). In addition, at least 20 observations per region-year and herd-year groups were required. Service sires with less than 50 AI observations were removed from the data set. Failure and success percentages per region-year, herd-year, and service sire groups were restricted to be between 15 and $85 \%$ to avoid extreme category problems (Moreno et al., 1997). The editing procedure reduced the initial data set to 501,284 AI records from 183,833 cows. Data from all lactations from a cow were present. The phenotypic probability of AI success was $37 \%$.

French sheep data came from a specific database built by the ANIO (Association National des Centres d'Insémination Ovine), which combines information from AI centers (information on males and characteris- tics of the semen) and the French national performance recording scheme (pedigree information and ewe performances). For this species, records of inseminations in the Manech Tête Rousse breed performed between 2000 and 2004 were used in the analysis. After male collection, semen was selected based on motility ( 0 to 5 scale, ejaculates with motility $<4$ were discarded) and diluted to obtain AI doses with standardized concentration $\left(1.2 \times 10^{6}\right.$ spermatozoa $\left./ \mathrm{mL}\right)$. Synchronized ewes were inseminated (cervical insemination) a few hours (1 to 8) after male collection with fresh semen. The AI outcome was defined as success (1) if lambing occurred 5 mo after insemination and failure (0) otherwise. After discarding service sires with less than 150 AI, 13,275 records were retained for the analysis; the observed probability of AI success was $51 \%$.

Rabbit data came from a population of a sire line selected for growth rate (Caldes line: Gómez et al., 2002). Data collected from June 2003 to December 2007 were used in this study. For the preparation of AI doses, ejaculates containing urine and calcium carbonate deposits were discarded, and gel plugs were removed. No evaluation of seminal characteristics was performed. Ejaculates were diluted 1:4 immediately after collection to obtain the AI doses. Female estrus and ovulation were induced by hormonal treatment. Artificial insemination doses of $0.5 \mathrm{~mL}$ were applied within $1 \mathrm{~h}$ after preparation on females from the same sire line, also reared in the nucleus of selection. Success or failure of AI was obtained from the diagnosis of pregnancy made by palpation $14 \mathrm{~d}$ after AI. Information on the day of parturition helped to confirm the previous diagnosis of palpation. A total of $6,543 \mathrm{AI}$ records were used for the analysis. The observed probability of AI success was $72 \%$.

\section{Methods}

Additive and product threshold models suppose different assumptions. In the additive threshold model, the observed phenotype is linked (probit link function) to a liability which is the sum of all genetic and environmental factors affecting male and female fertility. Thus, under the additive model the conditional probability of success given the genetic and environmental factors can be expressed as

$$
\begin{aligned}
& \operatorname{Pr}(\boldsymbol{y}=1 \mid \theta)= \\
& \Phi\left(\boldsymbol{X}_{f} \boldsymbol{b}_{\boldsymbol{f}}+\boldsymbol{X}_{\boldsymbol{m}} \boldsymbol{b}_{\boldsymbol{m}}+\boldsymbol{X}_{\boldsymbol{c}} \boldsymbol{b}_{\boldsymbol{c}}+\sum_{i} \boldsymbol{K}_{\boldsymbol{i}} \boldsymbol{f}_{i}+\sum_{n} \boldsymbol{M}_{n} \boldsymbol{m}_{n}\right. \\
& \left.+\sum_{j} \boldsymbol{L}_{\boldsymbol{j}} \boldsymbol{c}_{\boldsymbol{j}}+\boldsymbol{Z}_{\boldsymbol{f}} \boldsymbol{u}_{\boldsymbol{f}}+\boldsymbol{Z}_{\boldsymbol{m}} \boldsymbol{u}_{\boldsymbol{m}}+\boldsymbol{W}_{\boldsymbol{m}} \boldsymbol{p}_{\boldsymbol{m}}+\boldsymbol{W}_{f} \boldsymbol{p}_{\boldsymbol{f}}\right),
\end{aligned}
$$

where $\boldsymbol{y}$ is the vector of the binary results of inseminations; $\operatorname{Pr}(\boldsymbol{y}=1 \mid \theta)$ is the conditional (given the genetic and environmental factors variables $\theta$ ) probability of AI success. The $\Phi($.$) is the standard cumulative distribu-$ tion function of the normal distribution. The 
Table 1. Description of sheep, cattle, and rabbit data

\begin{tabular}{|c|c|c|c|}
\hline Item & Sheep & Cattle & Rabbit \\
\hline No. of females & 12,102 & 133,883 & 2,601 \\
\hline No. of males & 38 & 949 & 300 \\
\hline No. of AI records & 13,275 & 501,284 & 6,543 \\
\hline No. of animals in the pedigree & 37,213 & 216,373 & 3,302 \\
\hline \multirow[t]{2}{*}{ No. of observations per male ${ }^{1}$} & 350 & 528 & 21.8 \\
\hline & {$[217,423]$} & {$[133,369]$} & {$[9,30]$} \\
\hline \multirow[t]{2}{*}{ No. of observations per female ${ }^{1}$} & 1.1 & 3.7 & 2.5 \\
\hline & {$[1,1]$} & {$[2,5]$} & {$[1,3]$} \\
\hline \multirow[t]{2}{*}{ No. of different inseminated females per male ${ }^{1}$} & 347 & 443 & 19 \\
\hline & {$[216,421]$} & {$[120,326]$} & {$[9,26]$} \\
\hline \multirow[t]{2}{*}{ No. of different males per female ${ }^{1}$} & 1.0 & 3.1 & 2.2 \\
\hline & {$[1,1]$} & {$[1,4]$} & {$[1,3]$} \\
\hline \multirow[t]{2}{*}{ Probability of AI success per male ${ }^{1}$} & 0.52 & 0.37 & 0.70 \\
\hline & {$[0.49,0.53]$} & {$[0.32,0.42]$} & {$[0.60,0.83]$} \\
\hline \multirow[t]{2}{*}{ Probability of AI success per female ${ }^{1}$} & 0.51 & 0.45 & 0.69 \\
\hline & {$[0,1]$} & {$[0.17,0.67]$} & {$[0.50,1.00]$} \\
\hline Observed probability of AI success & 0.51 & 0.37 & 0.72 \\
\hline
\end{tabular}

${ }^{1}$ Values presented as mean [P25, P75]. P25, P75: 25th and 75th percentile.

$\boldsymbol{b}_{f}, \boldsymbol{b}_{m}$, and $\boldsymbol{b}_{c}$ are vectors of systematic effects related to the female, the male, or common to both sexes, respectively. The $\boldsymbol{u}_{f}$ and $\boldsymbol{u}_{m}$ are vectors of female and male fertility additive genetic effects, respectively. The

$\boldsymbol{p}_{\boldsymbol{m}}$ and $\boldsymbol{p}_{f}$ correspond to the vectors of male and female random permanent environmental effects; $\boldsymbol{f}_{i}, \boldsymbol{m}_{\boldsymbol{n}}$, and $\boldsymbol{c}_{j}$ are the random vectors of the $i$ th, $n$ th, and $j$ th effects specific to the female, male, or common to both sexes, respectively. The $\boldsymbol{X}_{f}, \boldsymbol{X}_{m}, \boldsymbol{X}_{c}, \boldsymbol{Z}_{f}, \boldsymbol{Z}_{m}, \boldsymbol{W}_{f}, \boldsymbol{W}_{m}, \boldsymbol{K}_{\boldsymbol{i}}, \boldsymbol{M}_{n}$, and $\boldsymbol{L}_{j}$ are corresponding known incidence matrices. On the other hand, the product threshold model considers that the conditional probability of AI success is the product of the probability of success of 2 binary unobserved phenotypes: the male and female fertilities (David et al., 2009). The 2 corresponding liabilities are the sum of genetic and environmental factors specific to the considered mate-sex and also those common to both sexes:

$$
\begin{aligned}
& \operatorname{Pr}(\boldsymbol{y}=1 \mid \theta)= \\
& \Phi\left(\boldsymbol{X}_{f} \boldsymbol{b}_{f}+\boldsymbol{X}_{\boldsymbol{c}} \boldsymbol{b}_{\boldsymbol{c}}+\sum_{i} \boldsymbol{K}_{i} \boldsymbol{f}_{i}+\sum_{j} \boldsymbol{L}_{j} \boldsymbol{c}_{j}+\boldsymbol{Z}_{f} \boldsymbol{u}_{f}+\boldsymbol{W}_{f} \boldsymbol{p}_{f}\right) \\
& \times \Phi\left(\boldsymbol{X}_{\boldsymbol{m}} \boldsymbol{b}_{\boldsymbol{m}}+\boldsymbol{X}_{\boldsymbol{c}} \boldsymbol{b}_{\boldsymbol{c}}+\sum_{n} \boldsymbol{M}_{\boldsymbol{n}} \boldsymbol{m}_{\boldsymbol{n}}+\sum_{j} \boldsymbol{L}_{j} \boldsymbol{c}_{j}\right. \\
& \left.+\boldsymbol{Z}_{\boldsymbol{m}} \boldsymbol{u}_{\boldsymbol{m}}+\boldsymbol{W}_{\boldsymbol{m}} \boldsymbol{p}_{\boldsymbol{m}}\right) .
\end{aligned}
$$

In both models, all random effects were assumed to be distributed following centered normal distributions with (co)variance matrices equal to $\left[\begin{array}{cc}\sigma_{u_{m}}^{2} & \sigma_{u_{f} u_{m}} \\ \sigma_{u_{f} u_{m}} & \sigma_{u_{f}}^{2}\end{array}\right] \otimes \boldsymbol{A}$ for the correlated genetic effects and $\mathbf{I}_{q} \sigma_{q}^{2}$ for the other random effects $q\left(q=\boldsymbol{c}_{\boldsymbol{j}}, \boldsymbol{m}_{\boldsymbol{n}}, \boldsymbol{f}_{\boldsymbol{i}}, \boldsymbol{p}_{\boldsymbol{f}}\right.$, or $\left.\boldsymbol{p}_{\boldsymbol{m}}\right)$, where $\boldsymbol{A}$ is the known relationship matrix and $\otimes$ represents the Kronecker product, $\mathbf{I}_{q}$ is an identity matrix of appropriate dimension, and $\sigma_{q}^{2}$ is the corresponding variance for the effect $q$. Nongenetic random effects were assumed to be independent of each other and of genetic effects.

Heritabilities on the observed scale were computed following the transformation proposed by Dempster and Lerner (1950): in the additive threshold model, $h_{\text {female_fertility }}^{2}=\frac{\sigma_{u_{f}}^{2}}{\sigma_{T}^{2}} \times z^{2} /\left[P_{o b s} \times\left(1-P_{o b s}\right)\right]$ and $h_{\text {male_fertility }}^{2}=\frac{\sigma_{u_{m}}^{2}}{\sigma_{T}^{2}} \times z^{2} /\left[P_{o b s} \times\left(1-P_{o b s}\right)\right]$, for the female and male fertility, respectively, where $P_{o b s}$ is the observed probability of AI success. The total variance $\sigma_{T}^{2}$ was calculated as $\sigma_{T}^{2}=\sigma_{u_{f}}^{2}+\sigma_{u_{m}}^{2}+\sigma_{p_{f}}^{2}+\sigma_{p_{m}}^{2}$ $+\sum_{i} \sigma_{f_{i}}^{2}+\sum_{n} \sigma_{m_{n}}^{2}+\sum_{j} \sigma_{c_{j}}^{2}$ and $z$ is the ordinate of a standard normal distribution function corresponding to a threshold equal to $\Phi^{-1}\left(P_{o b s}\right)$.

For the product threshold model, $h_{\text {female_fertility }}^{2}=\frac{\sigma_{u_{f}}^{2}}{\sigma_{T_{1}}^{2}} \times z_{f}^{2} /\left[P_{o b s} \times\left(1-P_{o b s}\right)\right]$ and $h_{\text {male_fertility }}^{2}=\frac{\sigma_{u_{m}}^{2}}{\sigma_{T_{2}}^{2}} \times z_{m}^{2} /\left[P_{o b s} \times\left(1-P_{o b s}\right)\right]$, for female and male fertility, respectively. Where $\sigma_{T_{1}}^{2}=\sigma_{u_{f}}^{2}+\sigma_{p_{f}}^{2}+\sum \sigma_{f_{i}}^{2}+\sum \sigma_{c 1_{j}}^{2} \quad$ and $\sigma_{T_{2}}^{2}=\sigma_{u_{m}}^{2}+\sigma_{p_{m}}^{2}+\sum_{n} \sigma_{m_{n}}^{2}+\sum_{j} \sigma_{c 2_{j}}^{2}$. The $z_{f}$ and $z_{m}$ are the ordinates of standard normal distribution functions corresponding to thresholds equal to $\Phi^{-1}\left(P_{f}\right)$ and $\Phi^{-1}\left(P_{m}\right)$. The $P_{f}, P_{m}$ are the probabilities of success for the unobserved phenotypes of female and male fertility, respectively. 
David et al.

Table 2. Effect included in models for sheep, cattle, and rabbit data

\begin{tabular}{|c|c|c|c|c|}
\hline \multirow[b]{2}{*}{ Type } & \multirow[b]{2}{*}{ Effect } & \multicolumn{3}{|c|}{ No. of levels } \\
\hline & & Sheep & Cattle & Rabbit \\
\hline \multicolumn{5}{|l|}{ Systematic } \\
\hline \multirow[t]{2}{*}{ Male effect } & Insemination No. & - & 5 & - \\
\hline & Motility & 12 & - & - \\
\hline \multirow[t]{9}{*}{ Female effect } & Rank of insemination & - & 5 & - \\
\hline & Interval with previous birth & 7 & $4^{1}$ & - \\
\hline & Region $\times$ year & - & 94 & - \\
\hline & Milk production & 4 & - & - \\
\hline & Physiological status of the female & 3 & - & 3 \\
\hline & Age & 7 & - & - \\
\hline & Lactation $\times$ age & - & 16 & - \\
\hline & Previous synchronization & 2 & - & - \\
\hline & No. of previous synchronizations & 8 & - & - \\
\hline Common effect & Day $\times$ inseminator & - & - & 22 \\
\hline \multicolumn{5}{|l|}{ Random } \\
\hline \multirow[t]{4}{*}{ Male effect } & Genetic male fertility & 37,213 & 216,373 & 3,302 \\
\hline & Permanent environmental effect & 38 & 949 & 300 \\
\hline & Permanent environmental effect $\times$ day & - & - & 1,232 \\
\hline & Inseminator & 37 & - & - \\
\hline \multirow[t]{3}{*}{ Female effect } & Genetic female fertility & 37,213 & 216,373 & 3,302 \\
\hline & Permanent environmental effect & - & 133,883 & 2,601 \\
\hline & Herd $\times$ year & 626 & - & - \\
\hline \multirow[t]{2}{*}{ Common effect } & Year $\times$ season & 31 & - & - \\
\hline & Herd $\times$ year & - & 6,567 & - \\
\hline
\end{tabular}

${ }^{1}$ Interval from calving to first AI.

\section{Implementation}

Data sets from the 3 species were analyzed using the additive and product threshold models. In each species, the same random, systematic, and genetic effects were included in both models. The systematic effects varied depending on the species (Table 2). Under the product model, effects were considered for each data set as specific to the male, to the female, or common to both sexes.

In a first step, additive and product threshold models were compared based on their ability of predicting new records as follows: $75 \%$ of records within species were used to estimate parameters, and the new records were predicted in the remaining $25 \%$. Five replicates of this design were randomly sampled. Different statistics were computed to evaluate the predictive ability of the 2 models: a) the percentage of wrong prediction; b) the mean square error of prediction (MSEP) defined as $M S E P=\frac{1}{n} \sum_{i}^{n}\left[y_{i}-\hat{P}\left(y_{i}=1\right)\right]^{2}$, where $y_{i}$ and $\hat{P}\left(y_{i}=1\right)$ correspond to the observed AI outcome and predicted probability of success, respectively, and $n$ is the number of data in a testing subset; c) the sensitivity of the prediction defined as the probability to predict a success given that the observation is a success; d) the specificity or the probability to predict a failure given that the observation is a failure; e) the negative predictive value defined as the probability to observe a failure given that the prediction is a failure; and $\mathrm{f}$ ) the positive predictive value or the probability to observe a success given that the prediction is a success.
In a second step, the estimated parameters obtained with the 2 models on the whole data set for each species were compared. The Pearson correlation between predicted breeding values and the percentage of animals in common in the top and bottom $10 \%$ animals were used to evaluate the differences in results between the 2 models.

Estimates were obtained using a Bayesian approach via Gibbs sampling. The core of the program is the TM (threshold model) software developed by Legarra et al. (2008). Flat priors were used for systematic effects and variance components, and starting values were randomly sampled. The Gibbs sampler analysis was implemented using one single chain consisting of 300,000, 400,000, and 500,000 iterations in sheep, cattle, and rabbits, respectively. After discarding the first 30,000 (sheep) or 50,000 (cattle and rabbit) iterations, samples of the parameters of interest were saved every 100 iterations. Inferences on the marginal posterior distributions were directly performed from the retained samples. Posterior means were used as parameter estimates.

\section{RESULTS}

Table 3 shows the predictive ability estimates for each model obtained for each criterion used. The MSEP estimates were similar between product and additive models within species. The percentages of wrong prediction for both models were in agreement for sheep and rabbit; however, a smaller percentage was obtained with the additive model in dairy cattle (35 vs. 47\%). The negative and positive predictive values are quite simi- 
Product versus additive model

Table 3. Predictive ability of the product and threshold models in sheep, cattle, and rabbits

\begin{tabular}{|c|c|c|c|c|c|c|}
\hline \multirow[b]{2}{*}{ Item } & \multicolumn{2}{|c|}{ Sheep } & \multicolumn{2}{|c|}{ Cattle } & \multicolumn{2}{|c|}{ Rabbit } \\
\hline & Product & Additive & Product & Additive & Product & Additive \\
\hline$\%$ of wrong prediction & 43 & 42 & 47 & 35 & 28 & 27 \\
\hline $\mathrm{MSEP}^{1}$ & 0.24 & 0.24 & 0.22 & 0.22 & 0.16 & 0.15 \\
\hline Sensitivity & 0.71 & 0.54 & 0.69 & 0.19 & 0.99 & 0.98 \\
\hline Specificity & 0.45 & 0.59 & 0.44 & 0.90 & 0.06 & 0.10 \\
\hline Negative predictive value & 0.70 & 0.65 & 0.73 & 0.68 & 0.66 & 0.66 \\
\hline Positive predictive value & 0.47 & 0.47 & 0.40 & 0.50 & 0.72 & 0.73 \\
\hline
\end{tabular}

${ }^{1} \mathrm{MSEP}=$ mean square error of prediction.

lar between models, whereas the product model tended to be more sensitive and less specific than the additive one. Between species, the MSEP and percentage of wrong prediction were, for both models, less in rabbits than in sheep and cattle. In both models, sensitivity increased from cattle (additive $=0.19$, product $=0.69$ ), to sheep (additive $=0.54$, product $=0.71$ ) and rabbits (additive $=0.98$, product $=0.99)$, whereas specificity decreased (cattle: 0.90 and 0.44 , sheep: 0.59 and 0.45 , rabbits: 0.10 and 0.06 for additive and product models, respectively). The negative predictive values were in the same range among species, whereas the positive predictive value was greater in rabbit than in sheep or cattle.

Results obtained for the whole data sets (Table 4) showed that the probability of success estimates for the unobserved phenotypes obtained from the product model were quite different between species. The probability of success of male fertility was greater than for female fertility in sheep (0.97 vs. 0.52$)$, less in cattle ( 0.57 vs. 0.65$)$, and similar in rabbits (0.87 vs. 0.83$)$.

Within species, heritability estimates on the underlying scale in the product model were greater than in the additive model (ratio ranging from 1 to 21). The estimated heritabilities on the observed scale were low for both traits $(<0.11)$ in all species and models. The heritabilities on the observed scale were greater $(\geq)$ for the product than for the additive model (ratio ranging from 1 to 5 ), but generally, credibility intervals overlap.

The posterior means of the genetic correlations between male and female fertilities were estimated with reduced credibility with either of the models or species, as credibility intervals ranged from -0.59 to 0.68 in sheep and from -0.72 and 1 in rabbit with the product model. Smaller credibility interval was found in dairy cattle (ranging from -0.24 to 0.15 ), suggesting a null genetic correlations between male and female fertilities.

The correlations between EBV for all animals in the pedigree obtained with the additive or product threshold models were large (ranging from 0.93 to 0.99 depending of the species) except for the male fertility in sheep (0.46). The same correlations calculated only with animals having records were generally greater (0.75 for male fertility in sheep). In accordance with the correlations, the percentage of animals in common in the $10 \%$ best/worst animals is large $(\geq 0.73)$, except for male fertility in sheep $(\leq 0.43)$.

\section{DISCUSSION}

Due to the process of editing data, the observed probabilities of AI success are slightly less than the one previously reported for the same breed in sheep $(0.57$; David et al., 2008) but in accordance with previous studies in rabbits (El Gaafary and Marai, 1994).

Under the product model, environmental factors can be distinctly attached to male, female, or to both, which cannot be done under an additive model. In our study, the assignment of environmental factors to male or female fertility, or both, has been somehow arbitrary. This choice is straightforward for some effects (e.g., age of the male, milk production) but not for all (e.g., inseminator). Consequently, the same factors did not affect the same trait depending of the species. For instance, the herd $\times$ year effect is linked to the female in sheep and to both sexes in cattle. The relevance of alternative effects acting on male or female fertility can be explored by classical model comparison techniques. We explored for a subset of the rabbit data the selection of effects in the product model. We first estimated parameters in a saturated model including all factors for male and female fertility. We removed step-by-step factors for which all credibility intervals included 0 . The final model obtained is consistent in the face of the factors included in both sides, illustrating the ability of the product model to correctly assign a factor as acting on male or female fertility, or both (results not shown). This was not carried out in our study for all species due to computing limitations and because it is not likely to affect the comparison between product and additive models, which was our goal. However, it has to be performed if the objective of the study is to analyze the factors influencing fertility.

The sampling method that we used to evaluate the predictive ability of the 2 models does not correspond to a standard 5-fold cross-validation (Shao, 1993). In this paper, random sampling was repeated 5 times, making sure that all random and systematic effect levels (except female permanent effect) in the testing sample were estimated previously in the training sample. This sampling method was used to avoid unexpected 
Table 4. Posterior means and credibility interval at 95\% [in brackets] of the probability of success for the unobserved phenotypes, genetic variances, heritabilities, and correlation between breeding values obtained with the additive and threshold models applied to the whole data set in sheep, cattle, and rabbits

\begin{tabular}{|c|c|c|c|c|c|c|}
\hline \multirow[b]{2}{*}{ Item } & \multicolumn{2}{|c|}{ Sheep } & \multicolumn{2}{|c|}{ Cattle } & \multicolumn{2}{|c|}{ Rabbit } \\
\hline & Product & Additive & Product & Additive & Product & Additive \\
\hline$P($ female fertility $=1)$ & $\begin{array}{l}0.52 \\
{[0.51,0.54]}\end{array}$ & - & $\begin{array}{l}0.65 \\
{[0.63,0.68]}\end{array}$ & - & $\begin{array}{l}0.83 \\
{[0.77,0.90]}\end{array}$ & - \\
\hline$P($ male fertility $=1)$ & $\begin{array}{l}0.97 \\
{[0.95,0.98]}\end{array}$ & - & {$[0.54,0.60]$} & - & $\begin{array}{l}0.87 \\
{[0.80,0.93]}\end{array}$ & - \\
\hline $\begin{array}{l}\text { Genetic variance of } \\
\text { female fertility }\end{array}$ & $\begin{array}{l}0.22 \\
{[0.15,0.30]}\end{array}$ & $\begin{array}{l}0.19 \\
{[0.13,0.27]}\end{array}$ & $\begin{array}{l}0.16 \\
{[0.13,0.19]}\end{array}$ & $\begin{array}{l}0.04 \\
{[0.03,0.05]}\end{array}$ & $\begin{array}{r}0.12 \\
{[<0.01,0.33]}\end{array}$ & $\begin{array}{l}0.04 \\
{[<0.01,0.09]}\end{array}$ \\
\hline $\begin{array}{l}\text { Genetic variance of } \\
\text { male fertility }\end{array}$ & $\begin{array}{l}2.30 \\
{[0.20,6.18]}\end{array}$ & $\begin{array}{l}0.02 \\
{[0.01,0.03]}\end{array}$ & $\begin{array}{l}0.02 \\
{[0.01,0.03]}\end{array}$ & $\begin{array}{l}0.01 \\
{[0.01,0.01]}\end{array}$ & $\begin{array}{l}0.47 \\
{[0.03,1.24]}\end{array}$ & $\begin{array}{l}0.05 \\
{[0.01,0.09]}\end{array}$ \\
\hline $\begin{array}{l}\text { Heritability on the } \\
\text { underlying scale of } \\
\text { female fertility }\end{array}$ & $\begin{array}{l}0.17 \\
{[0.12,0.22]}\end{array}$ & $\begin{array}{l}0.15 \\
{[0.10,0.20]}\end{array}$ & {$[0.11,09,13]$} & $\begin{array}{l}0.04 \\
{[0.03,0.04]}\end{array}$ & {$[<0.01,0.18]$} & $\begin{array}{l}0.03 \\
{[<0.01,0.06]}\end{array}$ \\
\hline $\begin{array}{l}\text { Heritability on the } \\
\text { underlying scale of } \\
\text { male fertility }\end{array}$ & $\begin{array}{l}0.36 \\
{[0.06,0.63]}\end{array}$ & $\begin{array}{l}0.02 \\
{[<0.01,0.03]}\end{array}$ & $\begin{array}{l}0.02 \\
{[0.01,0.03]}\end{array}$ & $\begin{aligned} & 0.01 \\
& {[<0.01,0.01] }\end{aligned}$ & $\begin{array}{l}0.17 \\
{[0.03,0.36]}\end{array}$ & $\begin{array}{l}0.04 \\
{[0.01,0.07]}\end{array}$ \\
\hline $\begin{array}{l}\text { Heritability on the } \\
\text { observed scale of } \\
\text { female fertility }\end{array}$ & $\begin{array}{l}0.11 \\
{[0.08,0.14]}\end{array}$ & $\begin{array}{l}0.09 \\
{[0.07,0.13]}\end{array}$ & $\begin{array}{l}0.06 \\
{[0.05,0.07]}\end{array}$ & $\begin{array}{l}0.02 \\
{[0.02,0.03]}\end{array}$ & $\begin{array}{l}\quad 0.04 \\
{[<0.01,0.10]}\end{array}$ & $\begin{aligned} & 0.02 \\
& {[<0.01,0.03] }\end{aligned}$ \\
\hline $\begin{array}{l}\text { Heritability on the } \\
\text { observed scale of } \\
\text { male fertility }\end{array}$ & $\begin{array}{l}\quad 0.01 \\
{[<0.01,0.02]}\end{array}$ & $\begin{array}{l}0.01 \\
{[<0.01,0.02]}\end{array}$ & $\begin{array}{c}0.01 \\
{[<0.01,0.02]}\end{array}$ & $\begin{array}{c}0.01 \\
{[<0.01,0.01]}\end{array}$ & $\begin{array}{l}0.10 \\
{[0.02,0.20]}\end{array}$ & $\begin{array}{c}0.02 \\
{[<0.01,0.04]}\end{array}$ \\
\hline Genetic correlation & $\begin{array}{l}0.04 \\
{[-0.59,0.68]}\end{array}$ & $\begin{array}{l}0.21 \\
{[-0.29,0.72]}\end{array}$ & $\begin{array}{l}-0.04 \\
{[-0.24,0.15]}\end{array}$ & $\begin{array}{l}-0.05 \\
{[-0.25,0.17]}\end{array}$ & $\begin{array}{l}\quad 0.21 \\
{[-0.72,1.00]}\end{array}$ & $\begin{array}{l}0.31 \\
{[-0.60,0.99]}\end{array}$ \\
\hline $\begin{array}{l}\text { Correlation between } \\
\text { female fertility EBV, } \\
\text { all animals/females } \\
\text { with records }\end{array}$ & $0.99 / 0.99$ & & $0.99 / 0$ & & $0.93 / 0$ & \\
\hline $\begin{array}{l}\text { Correlation between } \\
\text { male fertility EBV, } \\
\text { all animals/males } \\
\text { with records }\end{array}$ & $0.46 / 0.75$ & & $0.98 / 0$. & & $0.96 / 0$. & \\
\hline $\begin{array}{l}\text { Percentage of animals } \\
\text { in common in the top } \\
10 \% \text { best, bottom } \\
10 \% \text { worst animals } \\
\text { for female/male } \\
\text { fertility }\end{array}$ & $0.92,0.92$ & $22,0.43$ & $0.91,0$ & $0.91,0.80$ & $0.73,0$ & $.81,0.81$ \\
\hline
\end{tabular}

consequences of missing estimation for the additive or product models. Nonetheless, a 5-fold cross-validation was performed with the rabbit data and provided results very close to those presented in this study (results not shown). Within species, similar results obtained for MSEP and percentage of wrong prediction in rabbits and sheep show that product and additive threshold models have the same predictive ability. Nonetheless, as reported in previous studies for comparison with other models (Vazquez et al., 2009a,b), predictive ability of the models is different depending on the observed result. Thus, the product model was more sensitive and less specific than the additive one. Therefore, the product model had a better ability to predict a success and a worse ability to predict a failure than the additive model. For cattle, results are in favor of the additive threshold model that has a smaller percentage of wrong prediction. Even if models have similar predictive ability in sheep and rabbits, they provided different breeding values and animals will not be identically selected with the 2 models, especially for male fertility in sheep. These results suggest that either the additive or the product model may provide inaccurate predictions for male fertility. As true breeding values are unknown, further studies are necessary to determine what model is more accurate in predicting male fertility. An experimental selection with the 2 models, which could be carried out in rabbits, could be a way to give an answer to this question.

Heritabilities estimated with the additive threshold model were small for both traits, but in accordance with previous studies (González-Recio and Alenda, 2005; Piles et al., 2005; David et al., 2007). Heritabilities obtained with the product model cannot be related to the accuracy of the estimation or the genetic progress in the same manner as in the additive model. Therefore, estimation of heritabilities obtained with the 2 models cannot be properly compared, even if they are expressed in the observed scale. Further investigations are needed to give a practical interpretation of the heri- 
tability in the product threshold model. Conversely to the heritabilities, the genetic correlation between male and female fertilities can be compared across models. The $95 \%$ credibility intervals for all estimates were very large, and therefore we could not observe any differences between estimates. This result was in accordance with previous studies showing a wide range of genetic correlations between male and female fertilities: from $-0.53[-0.86,-0.01]$ (Varona and Noguera, 2001) to $0.73[-0.36,0.99]$ (Piles et al., 2005). However, in cattle, where a narrower credibility interval was obtained, the genetic correlation between male and female fertility seems to be small or null. Thus, the nature of this genetic correlation between both sexes for fertility still seems to be unclear and could differ between species.

Estimated probabilities of success for the unobserved phenotypes indicated that an AI failure was specifically due to female fertility problems for 94,32 , or $54 \%$ of the cases in sheep, cattle, and rabbits, respectively, and is specifically due to male fertility problems for 2 , 44 , and $39 \%$ of the cases in sheep, cattle, and rabbits, respectively. Therefore, the product model reports that an AI failure is mainly due to an impairment in female fertility in sheep and rabbits and due to an impairment in male fertility in cattle. It is difficult to compare these results with those reported previously in the literature. Actually, the only species where origin of infertility is well documented is humans after natural mating (Forti and Krausz, 1998). Forti and Krausz (1998) reported that in $35 \%$ of cases, infertility is mainly due to a female factor, in $30 \%$ to a male factor, in $20 \%$ to abnormalities detected in both partners, and in $15 \%$ of cases no diagnosis can be made after a complete investigation. Male fertility is supposed to behave differently between the 3 studied species. The uniqueness in the processes for preparing doses and insemination techniques may explain these differences. In sheep, semen is strongly selected upon its motility and sperm concentration; the doses have the same number of spermatozoa and are deposited in the female tract less than 6 $\mathrm{h}$ after collection (fresh semen). This process allows a control of main environmental factors reported in the literature as affecting male fertility (Briois and Guerin, 1995; Fernandez-Abella et al., 2003; Foote, 2003; Donovan et al., 2004). Conversely, there was no ejaculate selection upon its seminal characteristics (except urine or calcium deposits) in this study for rabbits, and there was no standardization of the dose concentration. This process may induce a decrease in the potential sperm fertility and explain the relative importance of the male in the AI failure. In dairy cattle, we observed the least probability of success for the male fertility. In this species, the sperm selection process is similar to the one performed in sheep but inseminations are performed with frozen semen. This difference may explain the greater relative importance of the male in AI failure in cattle. For female fertility, ovulation is induced after insemination in rabbits; therefore, the probability that the oocyte is released at the optimum time in the female reproductive tract is very large, which might explain the greatest percentage of female fertility success observed in this species (0.83). In sheep, females were inseminated regardless to expression of estrus, although they were estrus synchronized, which might explain the decreased probability of fertility success (0.52). On the other hand, the increased estimate of probability of success for female fertility in cattle (0.65) is surprising because female fertility problems have been largely reported as an explanation of the decrease of AI success observed in dairy cattle for a long time (Lucy, 2001).

The objective of this study was to evaluate in 3 species the performance of the product threshold model for the modeling of the outcome of AI. We have shown that its predictive ability is similar to the additive model in sheep and rabbit and slightly worse than the additive model in dairy cattle. When it holds, the product model has the advantage of extracting more information from the data than the additive threshold model. It is possible to evaluate which sex is responsible for an AI failure, and this would help to improve fertility. However, product model suffers from some drawbacks. In some cases a strong editing data process has to be done to ensure convergence (cattle and sheep in this study to avoid extreme category problems). Furthermore, interpretation of genetic parameters estimates is not straightforward and it is necessary to work on the estimation of the genetic progress in this model. At present, estimations are obtained using a Bayesian approach and the computing time is very long, which avoids the use of this model for large data sets. Finally, we think that the product model is, at present, an interesting model to test for studying AI results, or other traits with the same kind of associated binary unobserved phenotypes, in an experimental context.

\section{LITERATURE CITED}

Briois, M., and Y. Guerin. 1995. Essais de diminution du nombre de spermatozoïdes par dose conduits au centre d'insémination artificielle ovine de la confédération de roquefort. Pages 421-424 in Proc. 2nd Renc. Rech. Rumin., Paris, France. Institute de l'Elevage-INRA, Paris, France.

David, I., L. Bodin, D. Gianola, A. Legarra, E. Manfredi, and C. Robert-Granie. 2009. Product versus additive threshold models for analysis of reproduction outcomes in animal genetics. J. Anim. Sci. 87:2510-2518.

David, I., L. Bodin, G. Lagriffoul, C. Leymarie, E. Manfredi, and C. Robert-Granié. 2007. Genetic analysis of male and female fertility after AI in sheep: Comparison of single trait and joint models. J. Dairy Sci. 90:3917-3923.

David, I., C. Robert-Granié, E. Manfredi, G. Lagriffoul, and L. Bodin. 2008. Environmental and genetic variation factors of artificial insemination success in French dairy sheep. Animal 2:979-986.

Dempster, E. R., and I. M. Lerner. 1950. Heritability of threshold characters. Genetics 35:212-236.

Donovan, A., J. P. Hanrahan, E. Kummen, P. Duffy, and M. P. Boland. 2004. Fertility in the ewe following cervical insemination with fresh or frozen-thawed semen at a natural or synchronised oestrus. Anim. Reprod. Sci. 84:359-368. 
David et al.

El Gaafary, M. N., and I. F. M. Marai. 1994. Artificial insemination in rabbits. Pages 95-110 in Proc. 1st Int. Conf. on Rabbit Prod. in Hot Climates, Cairo, Egypt. CIHEAM, Paris, France.

Fernandez-Abella, D., M. O. Preve, and N. Villegas. 2003. Insemination time and dilution rate of cooled and chilled ram semen affects fertility. Theriogenology 60:21-26.

Foote, R. H. 2003. Fertility estimation: A review of past experience and future prospects. Anim. Reprod. Sci. 75:119-139.

Forti, G., and C. Krausz. 1998. Clinical review 100: Evaluation and treatment of the infertile couple. J. Clin. Endocrinol. Metab. 83:4177-4188.

Gómez, E. A., O. Rafel, and J. Ramon. 2002. The Caldes strain. Rabbit genetic resources in Mediterranean countries. Options méditerranéennes, serie B: Etudes et recherches 189-198.

González-Recio, O., and R. Alenda. 2005. Genetic parameters for female fertility traits and a fertility index in Spanish dairy cattle. J. Dairy Sci. 88:3282-3289.

Legarra, A., L. Varona, and E. López de Maturana. 2008. TM Threshold Model. Accessed Oct. 31, 2008. http://snp.toulouse. inra.fr/ alegarra/manualtm.pdf.

Lucy, M. C. 2001. Reproductive loss in high-producing dairy cattle: Where will it end? J. Dairy Sci. 84:1277-1293.
Moreno, C., D. Sorensen, L. A. Garcia-Cortes, L. Varona, and J. Altarriba. 1997. On biased inferences about variance components in the binary threshold model. Gen. Sel. Evol. 29:145-160.

Piles, M., O. Rafel, J. Ramon, and L. Varona. 2005. Genetic parameters of fertility in two lines of rabbits with different reproductive potential. J. Anim. Sci. 83:340-343.

Shao, J. 1993. Linear model selection by cross-validation. J. Am. Stat. Assoc. 88:486-494.

Speirs, A. L., A. Lopata, M. J. Grnow, G. N. Kellow, and W. I. H. Johnston. 1983. Analysis of the benefits and risks of multiple embryo transfer. Fertil. Steril. 39:468-471.

Varona, L., and J. L. Noguera. 2001. Variance components of fertility in Spanish Landrace pigs. Livest. Prod. Sci. 67:217-221.

Vazquez, A. I., D. Gianola, D. Bates, K. A. Weigel, and B. Heringstad. 2009a. Assessment of Poisson, logit, and linear models for genetic analysis of clinical mastitis in Norwegian Red cows. J. Dairy Sci. 92:739-748.

Vazquez, A. I., K. A. Weigel, D. Gianola, D. M. Bates, M. A. PerezCabal, G. J. M. Rosa, and Y. M. Chang. 2009b. Poisson versus threshold models for genetic analysis of clinical mastitis in US Holsteins. J. Dairy Sci. 92:5239-5247. 

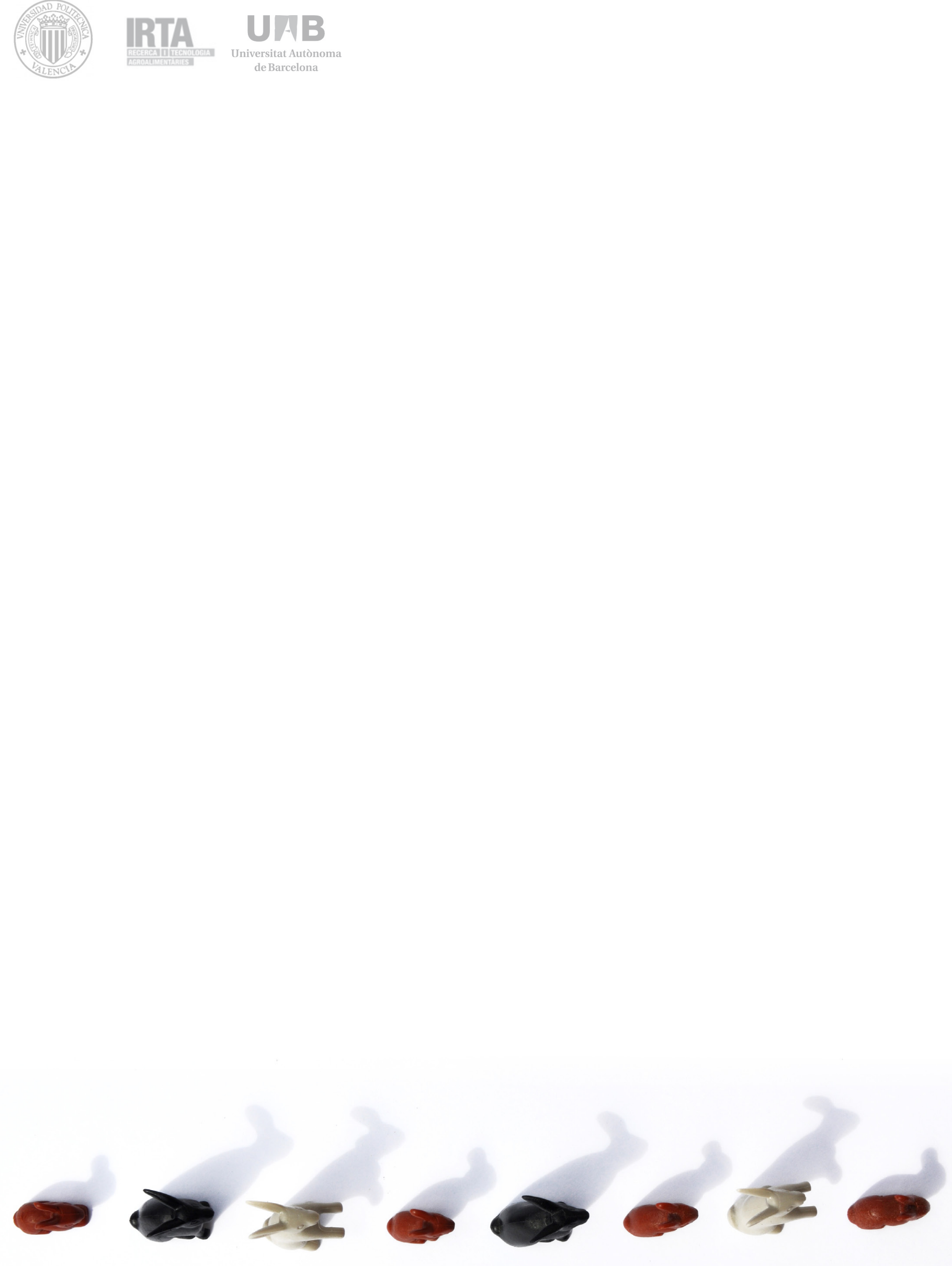